UNIVERSIDADE DE SÃO PAULO

FACULDADE DE MEDICINA DE RIBEIRÃO PRETO

DEPARTAMENTO DE MEDICINA SOCIAL

DOUTORADO SAÚDE NA COMUNIDADE

MURILO CÉSAR DO NASCIMENTO

Representações sociais de enfermeiros

da atenção primária à saúde sobre a dengue

Ribeirão Preto-SP

2016 
MURILO CÉSAR DO NASCIMENTO

Representações sociais de enfermeiros

da atenção primária à saúde sobre a dengue

Tese apresentada ao Programa de PósGraduação do Departamento de Medicina Social da Faculdade de Medicina de Ribeirão Preto Universidade de São Paulo - como requisito do Curso de Doutorado.

"Versão corrigida. A versão original encontra-se disponível tanto na Biblioteca da Unidade que aloja o Programa, quanto na Biblioteca Digital de Teses e Dissertações da USP (BDTD)".

Área de Concentração: Saúde na Comunidade

Orientador: Prof. Dr. Antonio Luiz RodriguesJúnior

Ribeirão Preto-SP 
Autorizo a reprodução e divulgação total ou parcial deste trabalho, por qualquer meio convencional ou eletrônico, para fins de estudo e pesquisa, desde que citada a fonte.

Dados Internacionais de Catalogação-na-Publicação (CIP)

Biblioteca Central da Universidade Federal de Alfenas

Nascimento, Murilo César do

Representações sociais de enfermeiros da atenção primária à saúde sobre a dengue / Murilo César do Nascimento. -- Ribeirão Preto/SP, 2016.

$175 \mathrm{p}$.

Orientador: Antonio Luiz Rodrigues-Júnior

Tese (Doutorado em Saúde na Comunidade) - Faculdade de Medicina de Ribeirão Preto, Universidade de São Paulo, 2016. Bibliografia.

1. Epidemias. 2. Saúde Pública. 3. Ação Intersetorial. 4. Pesquisa Qualitativa. 5. Dengue. I. Rodrigues-Júnior, Antonio Luiz. II. Título. 


\section{FOLHA DE APROVAÇÃO}

Murilo César do Nascimento

Representações sociais de enfermeiros da atenção primária à saúde sobre a dengue

Tese apresentada ao Programa de PósGraduação em Saúde na Comunidade do Departamento de Medicina Social da Faculdade de Medicina de Ribeirão Preto da Universidade de São Paulo, para a obtenção do título de Doutor em Ciências.

Aprovado em:

\section{Banca Examinadora}

Prof. Dr. Antônio Luiz Rodrigues-Júnior Assinatura:

Instituição: Faculdade de Medicina de Ribeirão Preto-USP. Julgamento:

Prof. Dr. Amaury Lélis Dal Fabbro

Assinatura:

Instituição: Faculdade de Medicina de Ribeirão Preto-USP. Julgamento:

Prof. Dr. Antonio Carlos Duarte de Carvalho Assinatura:

Instituição: Faculdade de Medicina de Ribeirão Preto-USP. Julgamento:

Prof $^{a}$ Dr ${ }^{\text {a }}$ Sueli Leiko Takamatsu Goyatá Assinatura:

Instituição: Universidade Federal de Alfenas, Unifal-MG. Julgamento:

Prof. Dr. José Vitor da Silva

Assinatura:

Instituição: Escola de Enfermagem Wenceslau Brás, EEWB. Julgamento: 
Dedico este trabalho àqueles que significam tudo pra mim:

Meu pai, Murilo Sérgio do Nascimento, Minha mãe, Elma Aparecida Ribeiro do Nascimento E minha irmã, Fernanda Ribeiro do Nascimento. 


\section{AGRADECIMENTOS}

Aos familiares, de forma particular, Murilo Sérgio do Nascimento, Elma Aparecida Ribeiro do Nascimento e Fernanda Ribeiro do Nascimento.

Aos amigos e colegas de trabalho, em especial, Maria Betânia Tinti de Andrade, Dênis de Oliveira Rodrigues e Júlio César Barbosa.

Ao professor, amigo e orientador, Prof. Dr. Antônio Luiz Rodrigues-Júnior.

Aos professores, principalmente, Prof. Dr. José Vitor da Silva, Prof. Dr. Amaury Lelis Dal Fabbro,

Prof. Dr. Antonio Carlos Duarte de Carvalho e Prof $^{a}$ Dra $^{a}$ Sueli Leiko Takamatsu Goyatá.

Aos parceiros e colaboradores, Escola de Enfermagem da Universidade Federal de Alfenas, Secretaria Municipal de Saúde de Alfenas de Alfenas, MG e Enfermeiras da Atenção Primária à Saúde de Alfenas, MG. 
"As palavras que representam o mundo e as coisas que nos rodeiam não são aleatórias $e$ dizem mais de nós do que se imagina. Carregam a marca do nosso tempo - e com as doenças não seria diferente".

(Denise Nacif Pimenta) 


\section{RESUMO}

Nascimento, M. C. do. Representações Sociais de Enfermeiros da Atenção Primária à Saúde sobre a Dengue. 2016. 175 p. Tese (Doutorado) - Faculdade de Medicina de Ribeirão Preto, Universidade de São Paulo, Ribeirão Preto, 2016.

A Dengue avança como um problema social cada vez mais expressivo. Por isso, foi desenvolvido este estudo cujos objetivos foram conhecer os significados da Dengue para os Enfermeiros da Atenção Primária à Saúde de Alfenas, Minas Gerais, bem como identificar forças restritivas e propulsoras para o controle da doença. Tratou-se de uma Pesquisa de Representação Social, de abordagem qualitativa, que adotou a Teoria das Representações Sociais e o Método do Discurso do Sujeito Coletivo como o referencial teórico-metodológico. O trabalho de campo contemplou entrevistas individuais aos Enfermeiros nas Unidades de Atenção Primária à Saúde do Município, entre junho e julho de 2015; os depoimentos foram gravados, transcritos e posteriormente analisados/apresentados por meio do Método do Discurso do Sujeito Coletivo. Os 17 profissionais de nível superior em enfermagem eram do sexo feminino e a média das idades foi de 40 anos; observou-se mediana de cinco anos de atuação na Atenção Primária à Saúde, sendo a maioria destas Enfermeiras integrantes de Equipes de Saúde da Família urbanas; três entrevistadas já tinham sido acometidas por Dengue. Do sujeito coletivo emergiram as seguintes Representações Sociais: desconforto enorme, problema de saúde pública, descuido das pessoas, consequência da falta de educação, doença viral, preocupação e medo, doença grave, doença causada pela picada do mosquito, epidemia, doença de país pobre, mais uma doença para a gente cuidar e uma guerra. Em relação ao controle da Dengue, foram reconhecidos como dificultadores: a falta de conscientização da população, a resistência e falta de responsabilidade das pessoas, a alta proliferação do mosquito, a grande quantidade de foco, os boatos, a falta de informação sobre a doença em si, o desconhecimento da causa, a capacitação dos Agentes de Controle de Endemias e a falta de mais cobrança dos Agentes Comunitários de Saúde; como facilitadores, o trabalho de orientação e de conscientização, a educação da população, a consciência das pessoas, o saneamento básico, as parcerias das Equipes de Saúde da Família com os Agentes de Controle de Endemias, a cobrança da população, a capacitação e a remuneração dos Agentes de Controle de Endemias e o dever da população. O conhecimento das Representações Sociais sobre a Dengue é importante para a compreensão da sua causalidade e para o enfrentamento do problema de Saúde Pública/Saúde Coletiva na atualidade. Do estudo emergiram valores e símbolos do sujeito coletivo de Enfermeiros da Atenção Primária à Saúde de Alfenas-MG sobre a Dengue e o enfrentamento da epidemia, que contribuíam com a inteligência dos serviços de saúde, por se tratar de profissionais que atuam na linha de frente do Município, promovendo o enfrentamento da doença.

Palavras-chave: Epidemias. Saúde Pública. Ação Intersetorial. Pesquisa Qualitativa. Dengue. 


\begin{abstract}
Nascimento, M. C. do. Social Representations of Primary Health Care Nurses on Dengue. 2016. 175 p. Thesis (Doctorate) - School of Medicine of Ribeirão Preto, University of São Paulo, Ribeirão Preto, 2016.

Dengue advances as an increasingly significant social problem. Thus, this study was developed with the aim to learn the meanings of Dengue for primary health care nurses from Alfenas, in the state of Minas Gerais; and to identify limiting and driving forces for its control. A social representation study was developed, with a qualitative approach, and the adoption of the social representation theory as its theoreticalmethodological framework. Field work consisted of individual interviews with nurses from the primary health care units of the city, between June and July of 2015; which were recorded, transcribed and later analyzed and presented by means of the discourse of the collective subject method. The 17 professionals interviewed had a nursing undergraduate degree, were women and had a mean age of 40 years. They presented a median length of activity in primary health care of five years, with most nurses being members of urban family health teams; and three nurses had already been infected by the Dengue virus. The collective subject resulted in the following social representations: extreme discomfort, public health problem, people's negligence, consequence of the lack of education, viral disease, concern and fear, severe disease, disease caused by a mosquito bite, epidemic, poor country's disease, one more disease for us to care for, and a war. According to the nurses, factors that make the control of Dengue difficult include: the population's lack of awareness, people's resistance and lack of responsibility, the mosquitoes' rapid spread, the high amount of focuses, rumors, lack of information on the disease, lack of knowledge on its cause, lack of qualification of workers of endemic diseases control, and lack of supervision on the work of community health workers. Factors that facilitate the disease control include the work to guide, educate and raise people's awareness, basic sanitation, partnerships of family health teams and endemic diseases control workers, demanding the population's commitment, better qualification and remuneration of endemic diseases control workers and the population's duty being served. Knowledge about social representations on Dengue is important to understand its causality and to cope with this current public health problem. This study managed to give rise to values and symbols of the collective subject of primary health care nurses from Alfenas on Dengue and the coping with the epidemic, which contributed to enhance the intelligence of health services, since these professionals work at the frontline of the city, promoting the fight against the disease.
\end{abstract}

Keywords: Epidemics. Public Health. Intersectoral Action. Qualitative Research. Dengue. 


\section{LISTA DE QUADROS}

Quadro 1 - Agrupamento das Ideias Centrais iguais, semelhantes e complementares do tema: "Significados da Dengue".

Quadro 2 - Significados da Dengue, conforme Ideias Centrais, participantes do estudo e frequência

Quadro 3 - Agrupamento das Ideias Centrais iguais, semelhantes e complementares do tema: "Dificultadores do controle da Dengue". 58

Quadro 4 - Dificultadores do controle da Dengue, conforme Ideias Centrais, participantes do estudo e frequência 59

Quadro 5 - Agrupamento das Ideias Centrais iguais, semelhantes e complementares do tema: "Facilitadores do controle da Dengue". 63

Quadro 6 - Facilitadores do controle da Dengue, conforme Ideias Centrais, participantes do estudo e frequência 64 


\section{LISTA DE FIGURAS}

Figura 1 - Modelo de Campo da Saúde de Marc Lalonde.

Figura 2 - Campo de Forças do Modelo de Campo Psicológico de Kurt Lewin. .29

Figura 3 - Significados da Dengue, segundo as Enfermeiras da Atenção Primária à Saúde de Alfenas, MG. 57

Figura 4 - Dificultadores para o controle da Dengue, segundo as

Enfermeiras da Atenção Primária à Saúde de Alfenas, MG. 61

Figura 5 - Facilitadores para o controle da Dengue, segundo as Enfermeiras da Atenção Primária à Saúde de Alfenas, MG. 69

Figura 6 - Campo de Forças para o controle da Dengue, segundo os Discursos do Sujeito Coletivo dos Enfermeiros da APS de Alfenas... 102 


\section{LISTA DE SIGLAS E ABREVIATURAS}

$A C$

ACE

ACS

APS

AS

COFEN

CONASEMS

CONASS

COREN-MG

DC

$\mathrm{dC}$

DENV

$\mathrm{Dr}$

DSC

E-Ch

ESF

EUA

FHD

GM/MS

IAD1

IAD2

IBGE

IC

MEI

$M G$

OMS

OPAS

OPS

PEAa

PIACD

PNCD
Ancoragens

Agente de Controle de Endemias

Agente Comunitário de Saúde

Atenção Primária à Saúde

Agentes de Saúde

Conselho Federal de Enfermagem

Conselhos Nacionais de Secretários Municipais

Conselhos Nacionais de Secretários Estaduais

Conselho Regional de Enfermagem de Minas Gerais

Dengue Clássico

Depois de Cristo

Sorotipo da Dengue

Doutor

Discurso do Sujeito Coletivo

Expressões-Chave

Estratégia Saúde da Família / Equipe de Saúde da Família

Estados Unidos da América

Febre Hemorrágica da Dengue

Gabinete do Ministro / Ministério da Saúde

Instrumento de Análise do Discurso 1

Instrumento de Análise do Discurso 2

Instituto Brasileiro de Geografia e Estatística

Ideias-Centrais

Materiais Educativos Impressos

Estado de Minas Gerais

Organização Mundial da Saúde

Organização Pan-Americana da Saúde

Organización Panamericana de la Salud

Programa de Erradicação do Aedes aegypti

Plano de Intensificação das Ações de Controle da Dengue

Plano Nacional de Controle da Dengue 


$\begin{array}{ll}\text { Prof } & \text { Professor } \\ \text { PSF } & \text { Programa Saúde da Família } \\ \text { RASs } & \text { Redes de Atenção à Saúde } \\ \text { RS } & \text { Representações Sociais } \\ \text { SCD } & \text { Síndrome do Choque da Dengue } \\ \text { SE } & \text { Semana Epidemiológica } \\ \text { SES-MG } & \text { Secretaria de Estado de Saúde de Minas Gerais } \\ \text { SMS } & \text { Secretaria Municipal de Saúde } \\ \text { SP } & \text { Estado de São Paulo } \\ \text { SUS } & \text { Sistema Único de Saúde } \\ \text { SUS } & \text { Sistema Único de Saúde } \\ \text { TRS } & \text { Teoria das Representações Sociais } \\ \text { UBS } & \text { Unidades Básicas de Saúde } \\ \text { UC } & \text { Universos Consensuais } \\ \text { UPC } & \text { Unidade de Pesquisa Clínica } \\ \text { UR } & \text { Universos Reificados } \\ \text { WHO } & \text { World Health Organization }\end{array}$




\section{SUMÁRIO}

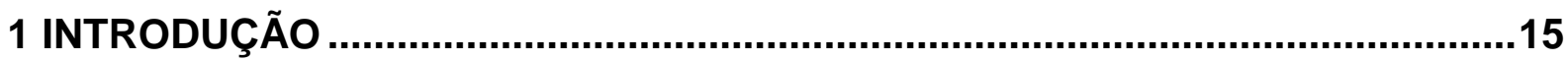

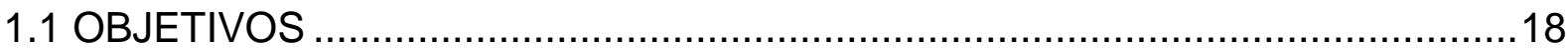

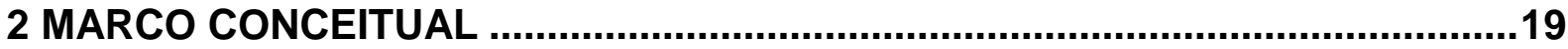

2.1 Dengue: Programas de Controle e DE Organização da Assistência....................19

2.2 Atenção Primária à Saúde, Dengue e Enfermagem..........................................24

2.3 Dengue, Modelo de Campo de Saúde e Modelo de Campo Psicológico .............27

3 REFERENCIAL TEÓRICO-METODOLÓGICO.....................................................30

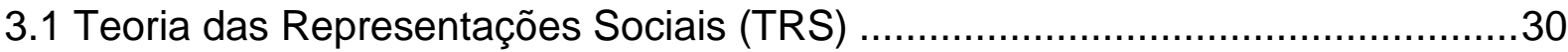

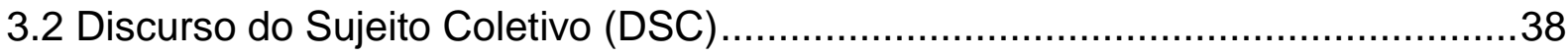

4 REPRESENTAÇÕES SOCIAIS SOBRE A DENGUE .........................................42

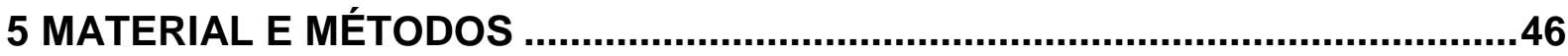

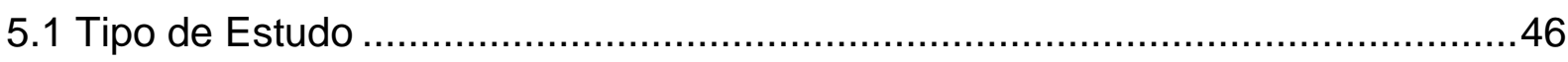

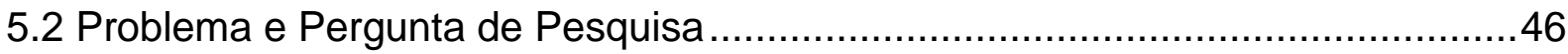

5.3 Atores, Campo Social e Lugar do Estudo......................................................... 46

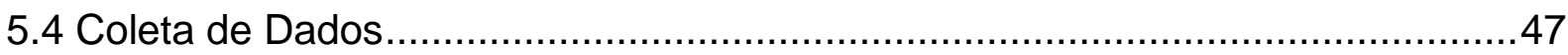

5.5 Organização, Exploração e Análise de Dados …………………....................48

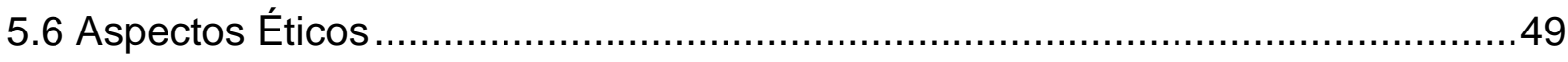

6 RESULTADOS

6.1 Características pessoais e profissionais dos participantes da pesquisa .............50

6.2 Temas estudados, agrupamentos, ideias centrais e DSC ................................50

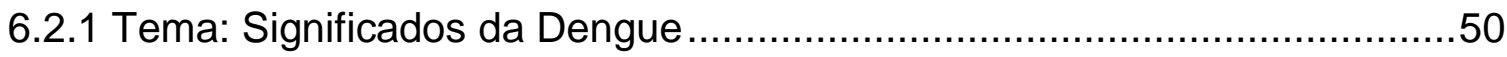

6.2.2 Tema: Dificultadores para o Controle da Dengue ...................................58

6.2.3 Tema: Facilitadores para o Controle da Dengue .....................................63

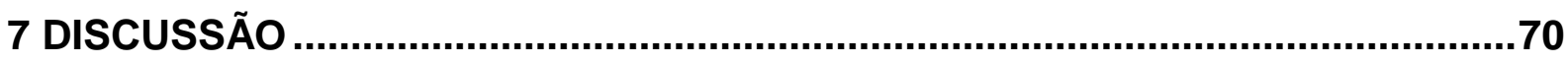

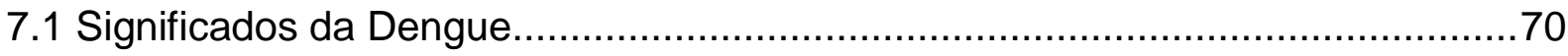

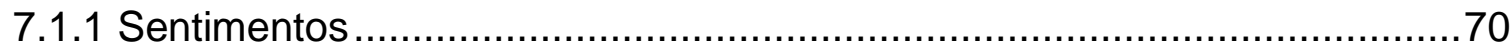

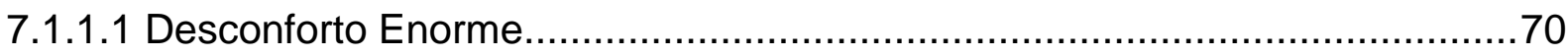

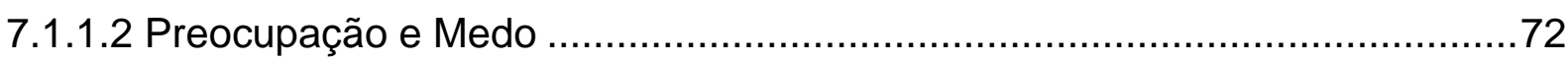

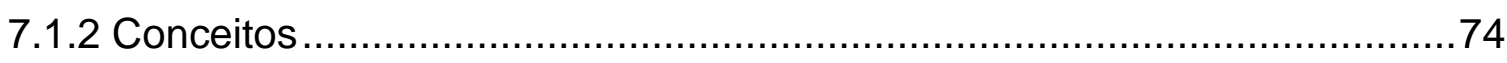

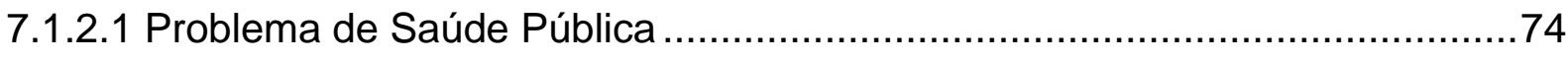

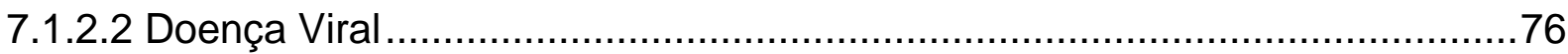


7.1.2.3 Doença Grave .78

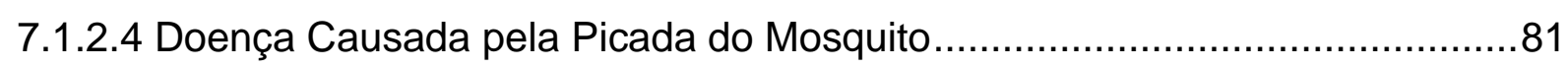

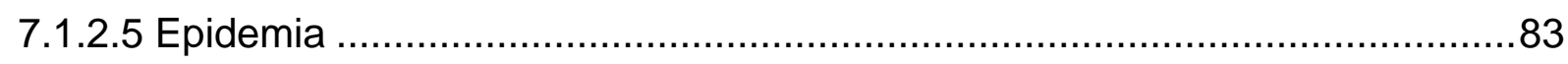

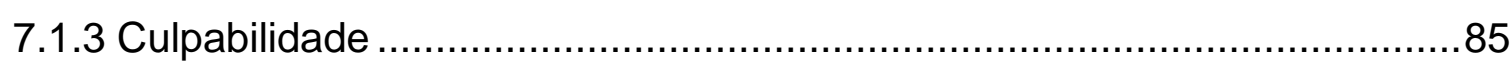

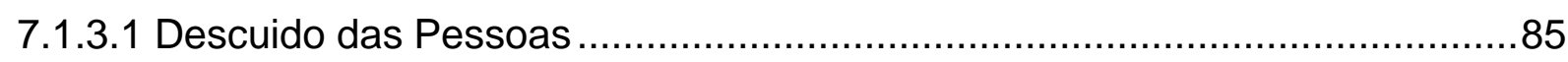

7.1.3.2 Consequência da Falta de Educação .....................................................87

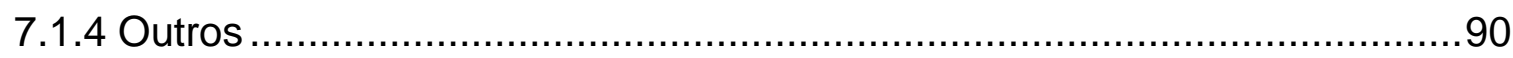

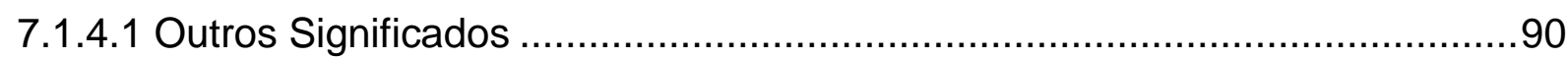

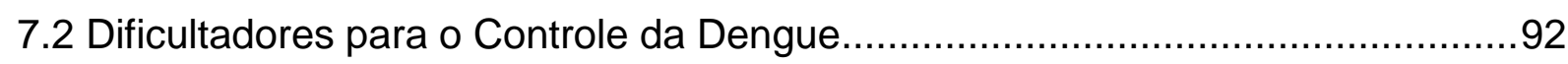

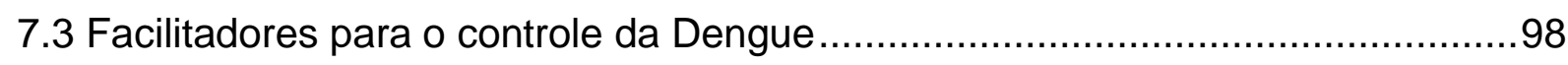

7.4 Síntese do Modelo de Campo de Força .........................................................101

8 CONCLUSÕES E CONSIDERAÇÕES FINAIS ..............................................105

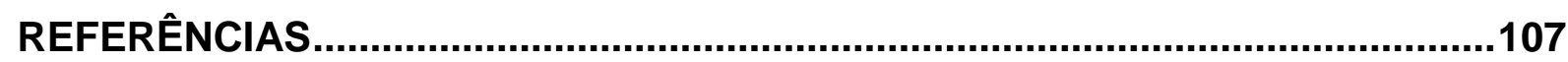

APÊNDICE A - Formulário de Entrevista ....................................................121

APÊNDICE B - Solicitação de Autorização da Pesquisa ..................................122

APÊNDICE C - Termo de Consentimento Livre e Esclarecido.........................123

APÊNDICE D - Relação da Produção Bibliográfica Derivada da Pesquisa .....126

APÊNDICE E - Comprovantes de Aceites, de Publicações e de Submissão ..127

ANEXO A - Parecer da Secretaria Municipal de Saúde - SMS ...........................132

ANEXO B - Parecer da Unidade de Pesquisa Clínica - UPC .............................133

ANEXO C - Folha de Rosto para Pesquisa - Plataforma Brasil.........................134

ANEXO D - Instrumento de Análise do Discurso 1 - IAD1 ...............................135

ANEXO E - Instrumento de Análise do Discurso 2 - IAD2 ..............................158 


\section{INTRODUÇÃO}

Não é de hoje que a Dengue reemerge ignorando as tentativas de controle e exercendo impacto negativo no contexto econômico, social e de saúde da população. Epidemias, outrora recorrentes nas regiões tropicais de países em desenvolvimento da Ásia, da África e das Américas, já têm sido observadas também em espaços extratropicais desenvolvidos como França, Croácia, Portugal, Espanha, Japão e Estados Unidos. Estima-se que o risco de infecção pelos vírus da Dengue envolva atualmente cerca de 2,5 a 2,9 bilhões de pessoas pelo mundo.

No Brasil, em 2015, haviam sido notificados 1.438 .497 casos de Dengue até a Semana Epidemiológica de número 36. Dessas notificações, foram confirmados 1.318 casos graves e 17.183 casos com sinais de alarme, o que equivale a um aumento de $194,68 \%$ e $214,92 \%$, respectivamente, em relação ao mesmo período de 2014. No Estado de Minas Gerais, até o dia 09 de dezembro de 2015, haviam sido confirmados 146.004 casos de Dengue Clássica e outros 35.723 tinham sido considerados suspeitos.

Já no Município Sul Mineiro de Alfenas, até o dia 05 de novembro de 2015 foram registrados 2037 casos confirmados da doença. Olhando para o número de casos de Dengue dos últimos quinze anos em Alfenas-MG, divididos por quinquênios, é possível notar que de 2011 a 2015 houve um incremento de $2314 \%$ em relação a 2001 a 2005; e de 3655\%, comparando-se com os anos de 2006 a 2010.

Diante desse cenário epidemiológico, a permanência da Dengue como um importante problema de saúde na atualidade constituiu a justificativa e a motivação principais para o presente trabalho. Ademais, ter conduzido uma pesquisa anterior sobre a Dengue em Alfenas-MG aguçou o interesse e a curiosidade sobre os determinantes/condicionantes não biológicos na manutenção da saúde e na produção desta doença.

As doenças transmitidas por vetores apresentam, sim, uma interação rica e dinâmica entre o vetor, o hospedeiro, e o agente patogênico, mas não se pode esquecer que tal interação ocorre tanto dentro de um contexto físico e biológico quanto num contexto histórico, social e cultural. Assim, as ciências sociais e humanas têm um papel importante para a compreensão de doenças como a 
Dengue, seja auxiliando na gestão da patogênese geral e/ou no controle de artrópodes.

Diante da complexidade do processo-saúde-doença da Dengue, seria ingenuidade acreditar como possível compreender tal fenômeno única e exclusivamente sob a perspectiva positivista da Matemática Social, baseada em estudos quantitativos e probabilísticos. Daí a importância de se trabalhar não somente os métodos quantitativos - frequentemente utilizados pelos epidemiologistas -, mas também as abordagens qualitativas.

Acredita-se que a Pesquisa Social, ao tratar do ser humano em sociedade, de suas relações e instituições, de sua história e de sua produção simbólica, oferece um arcabouço importante para a compreensão de fenômenos complexos, como o da Dengue no mundo altamente urbanizado em que vivemos. Nesse sentido, entendem-se como bem-vindas as Pesquisas Sociais em Saúde e por isso a nossa escolha pelas Pesquisas de Representação Social (RS).

A Teoria das Representações Sociais (TRS), referencial importante que foi resgatado do século $\mathrm{XIX}$, tem tido crescente utilização no desenvolvimento de pesquisas que consideram os aspectos psicossociais do processo saúde/doença na vida dos diversos grupos sociais. No Brasil, as Representações Sociais (RS) foram introduzidas na década de 1970, juntamente com o desenvolvimento da Psicologia Social, abordagem doravante adotada neste trabalho.

No caso da Dengue, conhecer como a doença é simbolizada ou figurada coletivamente pode contribuir para a compreensão do que e de como a sociedade pensa sobre o fenômeno. Considerando que, fundamentado na TRS, é possível procurar entender o porquê de as pessoas fazerem o que fazem, tal perspectiva desponta como arsenal interessante para discutir os significados da Dengue, bem como a participação e o comprometimento dos indivíduos/grupos nas ações de prevenção e de controle da doença. Sob esse prisma comportamental, as RS desempenham uma contribuição valiosa para a formação de condutas, uma vez que orientam as relações e as comunicações na sociedade.

Há evidências na literatura de que a utilização do Método do Discurso do Sujeito Coletivo (DSC) nas pesquisas de Representações Sociais da Dengue tem sido orientada tanto por objetivos acadêmicos quanto para fins operacionais e de planejamento da práxis em saúde coletiva. Entretanto, também é notório que o número de contribuições com essa abordagem é reduzido, motivo pelo qual se 
reitera a importância de que as $\mathrm{RS}$ sobre a Dengue sejam investigadas por meio do DSC em diversos segmentos da comunidade.

Já a escolha dos Enfermeiros da Atenção Primária à Saúde de Alfenas-MG como atores sociais desse processo de conhecimento sobre a Dengue, teve a ver com o interesse do autor pelo tema e também com o seu compromisso para com o segmento populacional de maior identificação profissional, social e acadêmica. Para além da curiosidade de natureza pessoal, a justificativa científica para a escolha dos sujeitos e dos campos sociais desta pesquisa diz respeito à proficuidade de se aproximar de uma categoria profissional, cujos relatos e experiência nos serviços de saúde podem contribuir também para a compreensão de questões organizacionais da assistência aos indivíduos e à coletividade durante as epidemias de Dengue.

Além disso, a TRS ajuda na compreensão de que as Representações Sociais dos diversos indivíduos que atuam nos serviços de saúde nem sempre são elaboradas somente com as ideias compartilhadas entre cada categoria profissional isoladamente. No processo histórico, cognitivo e social de interpretação da realidade, as representações dos Enfermeiros podem ser influenciadas pelo seu conhecimento científico; pelo seu embasamento pessoal e empírico; e pelos contatos, interações e comunicações cotidianas que intercambiam diversas informações do senso comum no campo social de sua pertença (faceta social).

Por isso, assumiu-se neste trabalho que, ao investigar os significados da Dengue, bem como as forças restritivas e propulsoras para o seu controle, os discursos dos Enfermeiros da APS também comportaram traços das representações sociais dos demais profissionais que compõem o "campo socialmente estruturado", Atenção Primária à Saúde; e não apenas o conjunto de significações coletivas dos colegas do "campo socialmente estruturado", Categoria Profissional Enfermeiro.

Este estudo veio complementarmente chamar a atenção para o fato de que o padrão de repetição do comportamento individual e coletivo pode estar ligado a representações simplistas, e por que não dizer, equivocadas e negativas do ponto de vista social, em relação ao processo saúde-doença da Dengue. Por isso os resultados foram discutidos ainda à luz do Modelo de Campo Psicológico e com o auxílio da Técnica de Análise de Campo provenientes da psicologia social.

Uma vez pensando na aproximação dos achados à abordagem epidemiológica, o Modelo de Campo de Saúde de Lalonde também foi utilizado como modelo de causalidade para a Dengue e sinalizou para a influência do agente 
etiológico, do meio ambiente, do estilo de vida e dos serviços de saúde no processosaúde doença da Dengue.

Diante disso, espera-se que este estudo contribua para um processo de reflexão, de discussão e de proposição de ações endereçadas ao controle desse problema de notória complexidade, extensão e magnitude: a Dengue. Espera-se ainda, que os resultados deste trabalho também despertem a atenção de outros grupos sociais, para além do setor saúde, que corroborem para o planejamento, para a execução e para o acompanhamento de políticas voltadas para um melhor enfrentamento desta doença.

\subsection{OBJETIVOS}

- Conhecer os significados da Dengue para os Enfermeiros da Atenção Primária à Saúde de Alfenas, Minas Gerais, Brasil.

- Identificar forças restritivas e propulsoras para o controle da Dengue, segundo a perspectiva desses profissionais. 


\section{MARCO CONCEITUAL}

\subsection{DENGUE: PROGRAMAS DE CONTROLE E DE ORGANIZAÇÃO DA ASSISTÊNCIA}

Registros de sintomas compatíveis com os da Dengue durante a dinastia Chin (265-420 dC), publicados formalmente em uma enciclopédia médica chinesa em 992 dC, evidenciam que a Dengue acompanha a humanidade há séculos. Entretanto, a etiologia viral e a transmissão por mosquitos só foram identificadas no Século XX (MURRAY; QUAM; WILDER-SMITH, 2013; GUBLER, 2006).

Doença infecciosa febril aguda, a Dengue é causada por um vírus de genoma RNA, do qual são conhecidos quatro sorotipos: o DENV-1, DENV-2, DENV-3 e o DENV-4 (BHATT et al., 2013; STAHL et al., 2013). Dados sobre o quinto sorotipo (DENV-5) foram apresentados em uma conferência realizada em outubro de 2013, em Bancoc, Tailândia. A descoberta foi feita pela equipe do Dr. Nikos Vasilakis da Universidade do Texas (EUA) que recebeu e analisou amostras de sangue coletadas durante uma epidemia de Dengue em 2007 na Malásia. O novo tipo é bastante distinto e segue o ciclo silvestre, ao contrário dos outros quatro sorotipos circulantes que seguem o ciclo humano (MUSTAFA et al., 2015; SOCIEDADE BRASILEIRA DE MEDICINA TROPICAL, 2013; BRASILSUS, 2013).

Transmitida ao homem pelo Aedes aegypti, como principal vetor, a Dengue classifica-se de acordo com a apresentação ou evolução clínica - leve ou grave - em: infecção inaparente, Dengue Clássico (DC), Febre Hemorrágica da Dengue (FHD) ou Síndrome do Choque da Dengue (SCD) (THOMAS, 2015). As formas graves constituem um percentual baixo em relação às formas leves, no entanto têm um elevado potencial de letalidade. A Dengue ocorre especialmente nos países tropicais, onde as condições do meio ambiente favorecem o desenvolvimento e a proliferação do Aedes aegypti (TORRES, 2005).

O número de infecções pelos vírus da Dengue tem aumentado em escala global, impactando na economia de diversos países e constituindo, dessa forma, um importante problema de saúde pública da atualidade (DICK et al., 2012; BHATT et al., 2013; STAHL et al., 2013). Com mais de 50 milhões de casos relatados à Organização Mundial da Saúde (OMS), a cada ano, a Dengue tem sido considerada 
a doença viral transmitida por mosquito mais importante do mundo (TAPIACONYER; BETANCOURT-CRAVIOTO; MENDEZ-GALVAN, 2012; GUZMAN et al., 2010).

Pesquisadores preveem que, apesar de variações espaciais influenciadas pelas chuvas, pela temperatura e pelo grau de urbanização, a Dengue se configura de modo onipresente ao longo dos trópicos. Alertam, ainda, que o total de infecções supera em mais de três vezes a estimativa da Organização Mundial da Saúde (BHATT et al., 2013). Segundo Tapia-Conyer; Betancourt-Cravioto e Mendez-Galvan (2012), aspectos como a própria clínica, os fatores socioeconômicos e a política têm contribuído para o ressurgimento da doença.

De acordo com Pimenta Júnior (2015, p. 387), o termo controle na área da saúde pública refere-se à redução da incidência de determinada doença a ponto de esta não ser mais considerada um problema para a coletividade. Nesse sentido, a utilização da expressão "controle da Dengue" no presente trabalho adotou o significado de controle como "o objetivo de uma ou mais atividades destinadas a reduzir a incidência de uma doença". Essa representação de controle é coerente no contexto da Dengue devido à inexequibilidade da erradicação deste agravo.

Pimenta (2015a, p. 39), citando Schweickardt $(2011)^{1}$, apresenta que "os vetores entraram para a agenda de pesquisa e para as políticas de saneamento para nunca mais sair." Segundo os autores, o pensamento original era de "tratar de endemias que afligiam os europeus nos trópicos e, posteriormente, combater e controlar doenças que atingiam as populações nativas, mão de obra para os europeus" na região dos trópicos.

Em relação às tentativas de controle da Dengue no Brasil, há tempos têm sido desenvolvidas ações de combate ao Aedes aegypti. O movimento de enfrentamento da doença que resultou na suposta erradicação do vetor em 1958 presenciou sua reinserção em 1976 e substituiu a inexequível estratégia de erradicação do mosquito transmissor pelos programas de controle entomológico em meados da década de 1980 (TEIXEIRA, 2002; TEIXEIRA; BARRETO, 1996).

Parte dessa nova política de enfrentamento incluiu a implantação do Programa de Erradicação do Aedes aegypti (PEAa) em 1996, do Plano de Intensificação das Ações de Controle da Dengue (PIACD) em 2001 e, em 2002, do 
Plano Nacional de Controle da Dengue (PNCD), cuja proposta era a de intensificar ações existentes e implementar novas estratégias com maior abrangência operacional (PESSANHA et al., 2009; BRASIL, 2002a).

Os objetivos do PNCD eram reduzir a infestação pelo Aedes aegypti, a incidência da Dengue e a letalidade por febre hemorrágica. Por conseguinte suas metas constituíam na redução da infestação predial nos municípios prioritários a menos de 1\%; na redução de 50\% do número de casos em 2003 em relação a 2002 e, nos anos seguintes, 25\% a cada ano; e na redução da letalidade por febre hemorrágica a menos de 1\% (BRASIL, 2002a). No ano seguinte, o Ministério da Saúde criou o Levantamento de Índice Rápido do Aedes aegypti (LIRAa), ainda em vigor, que consiste em mapear os locais exatos onde se registram altos índices de infestação predial do mosquito da Dengue (BRASIL, 2005a; 2005b).

Num cenário epidemiológico caracterizado por tríplice carga de doenças, onde a transição demográfica acentua os índices de doenças não-transmissíveis, a urbanização somada à desigualdade social agravam a morbi-mortalidade por causas externas, e as doenças infecciosas/parasitárias, maternas, perinatais e nutricionais não podem ser consideradas superadas, há que se investir em mudanças no sistema de saúde convencional.

Essa forma de organizar os serviços de modo a responder aos problemas de saúde é uma das acepções do conceito de integralidade (BRASIL, 2011a). Segundo Fracolli et al. (2011) e Matos e Pires (2009), esse princípio doutrinário da política e do sistema de saúde brasileiro traz em si o compromisso ético-político de trabalho em rede, uma vez que deve ser fruto de uma articulação de cada serviço de saúde, pensada no espaço singular de cada unidade e na ação de cada profissional de saúde.

Um passo importante nesse sentido foi criação da Secretaria Nacional de Vigilância em Saúde no Ministério da Saúde, em 2003, com a instituição do Sistema Nacional de Vigilância em Saúde. A Vigilância em Saúde busca contemplar os princípios da integralidade e da atenção, combinando diversas tecnologias para intervir sobre a realidade da saúde; essa nova forma de trabalho tenta superar a visão isolada e fragmentada na formulação das políticas de saúde e na organização das ações e dos serviços (BRASIL, 2007a).

Desse modo, o Sistema Nacional de Vigilância em Saúde passou a integrar diversas ações das vigilâncias epidemiológica, ambiental e sanitária - dirigidas à 
prevenção de riscos e danos - e da Atenção Primária - realizadas nos domicílios e nas unidades de saúde. Essa iniciativa fortaleceu e ampliou o espectro do gerenciamento de risco, principalmente na vigilância epidemiológica e na vigilância sanitária, que possuem, como parte de suas ações estratégicas, a integração com os serviços de saúde (BRASIL, 2011a).

Outro avanço importante para a política de saúde nacional foi a aprovação do Pacto pela Saúde pelo Conselho Nacional de Saúde. Publicado na Portaria GM/MS no399, de 22 de fevereiro de 2006, o Referido Pacto (composto pelo Pacto Pela Vida, pelo Pacto em Defesa do SUS e pelo Pacto de Gestão) tinha e tem como objetivo promover a melhoria dos serviços ofertados à população e a garantia de acesso a todos. Desse modo, a sua adesão constitui um processo de cooperação permanente entre os gestores e a negociação local, regional, estadual e federal (BRASIL, 2011b; BRASIL, 2006a).

Dentre as prioridades do Pacto Pela Vida e seus objetivos para 2006, estava o fortalecimento da capacidade de resposta às doenças emergentes e às endemias, com ênfase na Dengue, na hanseníase, na tuberculose, na malária e na influenza. Os objetivos e metas elencados para o controle da Dengue foram: a) Plano de Contingência para atenção aos pacientes, elaborado e implantado nos municípios prioritários, em 2006; b) Reduzir para menos de 1\% a infestação predial por Aedes aegypti em 30\% dos municípios prioritários até 2006 (BRASIL, 2006b).

Três anos mais tarde, o Ministério da Saúde elaborou em parceria com os Conselhos Nacionais de Secretários Estaduais (CONASS) e Municipais (CONASEMS) de Saúde as Diretrizes Nacionais para Prevenção e Controle de Epidemias de Dengue. Tal documento forneceu orientações para unificar as ações de vigilância e de assistência em saúde para o combate à Dengue em todos os Estados e municípios do país (OPAS/OMS/BRASIL, 2009; BRASIL, 2009a). O objetivo das Diretrizes de 2009 foi de evitar a ocorrência de óbitos por Dengue, bem como prevenir e controlar processos epidêmicos (PIMENTA JÚNIOR, 2015).

Costa (2011) explica que, com a implantação do PNCD, o governo federal transferiu aos municípios a responsabilidade quase exclusiva pelo controle da Dengue: ações de bloqueio da transmissão, de vigilância entomológica, de ampliação do saneamento, de notificação dos casos, de coleta de material para sorologia e isolamento viral, de organização de plano de contingência para internação dos pacientes com Dengue e de mobilização social. Com isso, o 
cumprimento de tais tarefas tornou-se dependente da capacidade de planejamento e de gestão em saúde local.

Em relação à provisão de recursos para o enfrentamento das epidemias de Dengue, o Ministério da Saúde publicou em novembro de 2013 a Portaria no 2.760, de 19 de novembro de 2013, a qual autoriza o repasse de incentivo financeiro para a qualificação das ações de vigilância, de prevenção e de controle da Dengue (BRASIL, 2013).

Já no que se refere ao manejo clínico dos usuários com suspeita de Dengue, Tauil (2002) afirma como possível reduzir os coeficientes de letalidade pela doença em torno de $1 \%$, por meio da organização do sistema de assistência aos casos suspeitos. Até o ano de 2015, não havia sido registrado em Alfenas nenhum caso autóctone de Dengue que tivesse evoluído para óbito. Entretanto, considerando que as manifestações clínicas da doença têm se mostrado mais intensas a cada ano, há que se pensar de forma preventiva na reorganização dos pontos de atenção à saúde do Município, de modo a evitar ao máximo as complicações, as formas graves e as mortes por Dengue.

Segundo Mendes (2011), os sistemas de atenção à saúde atravessam uma crise contemporânea que resulta da incompatibilidade entre uma situação epidemiológica dominada pelas condições crônicas e um sistema de atenção à saúde voltado para responder às condições e aos eventos agudos. Para Mendes, essa incoerência também é percebida no Sistema Único de Saúde Brasileiro, o qual tem sido praticado de forma reativa, episódica e fragmentada. O autor argumenta, ainda, que a superação desse descompasso só será alcançada com a substituição do sistema atual pelas Redes de Atenção à Saúde (RASs).

Apesar de a abordagem proposta por Mendes (2011) estar inserida num contexto cujo foco principal é a melhoria das condições de saúde por meio do manejo mais efetivo dos portadores de doenças crônicas, as evidências internacionais por ele apresentadas de que as RASs melhoram os resultados sanitários e econômicos dos sistemas de atenção à saúde fazem imaginar que tal mudança também é compatível com a atenção aos indivíduos com Dengue.

Acredita-se que essas novas formas de organização social (as RASs) - já trabalhadas em várias áreas como a sociologia, a psicologia social, a administração, e a tecnologia de informação (MENDES, 2011; CASTELLS, 2000) - podem contribuir, por exemplo, para a redução da letalidade por Dengue. Essa possibilidade 
é corroborada por Cunha e Martínez (2015, p. 230) ao discorrerem que um "processo organizado para a triagem e a tomada de decisões clínicas em todos os níveis da rede de saúde" é condição necessária para a redução do número de hospitalizações e de mortalidade por Dengue.

Cunha e Martínez (2015, p. 230), em conformidade com a OPS (2010), destacam a importância dos níveis primários e secundários de atenção à saúde por ocorrerem nestes espaços o primeiro contato, a avaliação, a identificação do risco de desenvolver Dengue grave e a designação de atendimento diferenciado caso necessário. Já a organização do sistema de assistência aos casos suspeitos de Dengue sugerida por Tauil (2002), refere-se a um plano estratégico municipal de atendimento aos usuários, a fim de facilitar seu acesso precoce aos serviços de saúde.

\subsection{ATENÇÃO PRIMÁRIA À SAÚDE, DENGUE E ENFERMAGEM}

Segundo Lavras (2011), apesar das divergências a respeito da definição de Atenção Primária à Saúde (APS), o termo é consensualmente entendido como uma atenção ambulatorial não especializada que é oferecida em unidades de saúde e cujas atividades clínicas desenvolvidas caracterizam-se por baixa densidade tecnológica. Mendes (2011) lembra que demandar menos aparato tecnológico não significa que as práticas realizadas na APS configuram-se primitivas, menos complexas ou menos importantes do que as exercitadas nos níveis secundário e terciário de atenção à saúde.

De acordo com Starfield (2002), as práticas da atenção primária são regidas por quatro atributos/princípios: primeiro contato, longitudinalidade, integralidade e coordenação do cuidado. Carmen Lavras concatena os princípios apresentados por Starfield da seguinte maneira:

[...] a APS responsabiliza-se pela atenção à saúde de seus usuários, constituindo-se na principal porta de entrada do sistema; ofertando ações de saúde de caráter individual e coletivo; organizando o processo de trabalho de equipes multiprofissionais na perspectiva de abordagem integral do processo saúde doença; garantindo acesso a qualquer outra unidade funcional do sistema em função das necessidades de cada usuário; responsabilizando-se por esse usuário, independentemente de seu atendimento estar se dando em outra unidade do sistema; e, dessa forma, ordenando o funcionamento da rede [...] (LAVRAS, 2011, p. 873). 
Já Mendes, ao discorrer sobre os atributos para uma APS de qualidade, acrescenta três princípios à proposta de Starfield: a focalização na família, a orientação comunitária e a competência cultural. A seguir, a explicação nas palavras do próprio autor:

\begin{abstract}
A focalização na família implica considerar a família como o sujeito da atenção, o que exige uma interação da equipe de saúde com essa unidade social e o conhecimento integral de seus problemas de saúde. A orientação comunitária significa o reconhecimento das necessidades das famílias em função do contexto físico, econômico, social e cultural em que vivem, o que exige uma análise situacional das necessidades de saúde das famílias numa perspectiva populacional e a sua integração em programas intersetoriais de enfrentamento dos determinantes sociais da saúde. A competência cultural exige uma relação horizontal entre a equipe de saúde e a população que respeite as singularidades culturais e as preferências das pessoas e das famílias (MENDES, 2011, p. 97).
\end{abstract}

Após a I Conferência Internacional sobre cuidados primários de Saúde, realizada em 1978 em Alma-Ata, no Cazaquistão, o que se viu foi um direcionamento das políticas de saúde ao elevar a Atenção Primária à Saúde (APS) à condição de principal estratégia de promoção e de assistência à saúde (PEREIRA; OLIVEIRA, 2014; OLIVEIRA; PEREIRA, 2013; OMS/UNICEF, 1979).

No Brasil, a Atenção Primária à Saúde foi reforçada como estratégia de reordenamento do Sistema Único de Saúde (SUS), no plano jurídico, por meio do Decreto oㅜ 7.508, de 28 de junho de 2011, o qual regulamenta a Lei Orgânica do SUS (PEREIRA; OLIVEIRA, 2014; BRASIL, 2011c); e no plano político, pela implantação da atual Política Nacional de Atenção Básica. Nessa política, a Estratégia Saúde da Família (ESF) é considerada o eixo articulador do sistema de saúde em seu conjunto, e a principal porta de entrada para o atendimento (BRASIL, 2012).

Segundo Pereira e Oliveira (2014, p. 11), a ESF propõe a atenção à saúde orientada pela vigilância em saúde, "combinando ações de promoção, prevenção e cura, desenvolvidas por uma equipe multidisciplinar com responsabilização sanitária sobre um território definido". As autoras explicam que, como estratégia de reorientação do modelo assistencial, "a ESF propõe mudanças no objeto de atenção e na forma de organização dos serviços e das ações de saúde, pois o foco passa a ser o indivíduo, a família e seu ambiente físico e social" (PEREIRA; OLIVEIRA, 2014, p. 12). De acordo com Brasil (2009b), $65-75 \%$ dos casos de Dengue podem ser resolvidos em Atenção Primária que conte com uma rede assistencial efetiva. 
Em relação ao enfrentamento da Dengue, de forma integrada e articulada com os demais serviços de saúde da rede, como as Unidades de Saúde da Família, por exemplo, um avanço importante foi a publicação da Portaria $n^{\circ}$ 1.007/GM/MS, de 4 de maio de 2010. Isso porque tal documento define critérios para regulamentar a incorporação do Agente de Controle de Endemias - ACE - na Atenção Primária à Saúde com o intuito de fortalecer as ações de vigilância em saúde junto às Equipes de Saúde da Família (BRASIL, 2010).

Chiaravalloti Neto et al. (2006) já chamavam a atenção para a viabilidade da integração entre Agente de Controle de Endemias (ACE) e Agentes Comunitários de Saúde (ACS), a exemplo de um trabalho realizado num município do interior paulista. Para os autores, tal articulação intrasetorial representa otimização de recursos ao evitar a duplicidade das visitas e possibilita um maior envolvimento da comunidade no controle da Dengue.

Ainda com o olhar para os atores da Atenção Primária à Saúde, nota-se que o enfermeiro é um profissional historicamente identificado pelo compromisso com a saúde pública e pela grande capilaridade social, estando presente na maioria das ações desenvolvidas no Sistema Único de Saúde - SUS (BRASIL, 2002b). Ademais, segundo os princípios fundamentais do Código de Ética dos Profissionais de Enfermagem, a "enfermagem é uma profissão comprometida com a saúde e a qualidade de vida da pessoa, família e coletividade". De acordo com a Resolução COFEN №. 311, de 08 de Fevereiro de 2007:

\footnotetext{
O profissional de enfermagem atua na promoção, prevenção, recuperação e reabilitação da saúde, com autonomia e em consonância com os preceitos éticos e legais. O profissional de enfermagem participa, como integrante da equipe de saúde, das ações que visem satisfazer as necessidades de saúde da população e da defesa dos princípios das políticas públicas de saúde e ambientais, que garantam a universalidade de acesso aos serviços de saúde, integralidade da assistência, resolutividade, preservação da autonomia das pessoas, participação da comunidade, hierarquização e descentralização político-administrativa dos serviços de saúde (CORENMG, 2013, p. 49).
}

Kawamoto (1995) expõe que a enfermagem desempenha papel relevante no processo saúde-doença, uma vez que atua nos diferentes níveis de prevenção. Os enfermeiros organizam a equipe e os usuários em relação à vigilância/eliminação dos focos potenciais de infecção no território, trabalham com educação em saúde e prestam assistência direta na comunidade (KAWAMOTO, 1995). Dessa forma, 
Cezar-Vaz et al. (2010) acrescentam que a prática do enfermeiro objetiva a redução dos potenciais de riscos à saúde e a modificação dos estilos de vida dos indivíduos nas comunidades.

Devido à experiência do profissional enfermeiro nas atividades de prevenção, de manejo do tratamento, de ações de vigilância epidemiológica e de controle das enfermidades (BRASIL, 2008), acredita-se que acessar suas representações sociais sobre a Dengue seja um passo importante para um melhor conhecimento sobre essa doença. A discussão dos significados à luz de modelos explicativos oriundos da Epidemiologia e da Psicologia Social constitui em um incremento importante para a reflexão sobre esse processo saúde-doença.

\subsection{DENGUE, MODELO DE CAMPO DE SAÚDE E MODELO DE CAMPO PSICOLÓGICO}

A proposição de estratégias para o enfrentamento de agravos à saúde deve levar em conta os fatores sociais, naturais, assistenciais à saúde, comportamentais e biológicos dos indivíduos de uma comunidade. Por isso é importante pensar o processo saúde-doença da Dengue sob a perspectiva de modelos atuais e abrangentes.

O Modelo de Campo de Saúde refere-se a um modelo de causalidade apresentado pelo epidemiologista e ex-ministro de saúde canadense Marc Lalonde. Registrado no documento que ficou conhecido como Relatório Lalonde, o modo abrangedor de analisar as causas e os fatores predisponentes dos problemas de saúde alcançou visibilidade mundial (LALONDE, 1974; PEREIRA; OLIVEIRA, 2014).

$\mathrm{Na}$ concepção de Lalonde, as doenças são determinadas/condicionadas por fatores relacionados a: 1) hospedeiro; 2) meio ambiente; 3) estilo de vida; e 4) organização dos serviços de saúde. Assim, na prática, o enfrentamento dos problemas de saúde também deve ser buscado na interface dos quatro componentes (PEREIRA; OLIVEIRA, 2014), conforme apresentado na Figura 1. 
Figura 1 - Modelo de Campo da Saúde de Marc Lalonde.

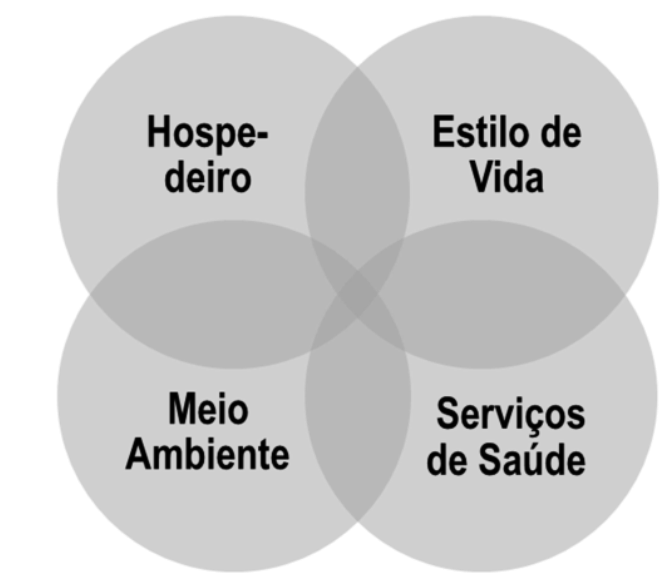

Fonte: Adaptado de Pereira e Oliveira (2014) e Lalonde (1974)

Pereira e Oliveira (2014, p. 44) explicam que, no Modelo de Campo de Saúde, os fatores relacionados ao hospedeiro relacionam-se com o genótipo e com 0 fenótipo dos indivíduos e aos diversos processos patogênicos que afligem o ser humano; os fatores relativos ao ambiente podem compreender as condições sociais e naturais, incluindo o trabalho, o lazer, o entretenimento, a cultura, etc., e também a contaminação do ar, da água, do solo, dos alimentos, etc.; em relação ao estilo de vida, podem ser considerados o comportamento humano e seus riscos autoimpostos; finalmente, os fatores relacionados à organização da assistência à saúde devem considerar o efeito dos elementos vinculados às estruturas, aos processos e aos resultados dos serviços de saúde.

O município de Alfenas tem passado de um cenário epidemiológico marcado por epidemias de Dengue pouco expressivas para uma realidade de incidência progressiva e hiperepidemia, como a observada no ano de 2015. Nesse sentido, além da preocupação com os efeitos do DENV no hospedeiro, referentes ao componente "hospedeiro" no Modelo de Lalonde, entende-se oportuna uma discussão mais aprofundada também sobre as questões social, comportamental e organizacional que envolvem as epidemias de Dengue.

Para tanto, um raciocínio interessante que permite a identificação de forças retratoras e propulsoras ao alcance de determinado objetivo é observado no Modelo de Campo Psicológico do psicólogo social alemão Kurt Lewin. Para Lewin, o campo psicológico é representado por linhas de força que atraem a percepção do indivíduo sobre determinado evento/objeto e Ihe dão significado. De acordo com Rodrigues- 
Júnior (2012, p. 262) a técnica da análise do campo de força relaciona-se estreitamente com o raciocínio Gestalt. A Figura 2 apresenta um esquema do Campo de Forças, conforme o Modelo de Campo Psicológico de Kurt Lewin.

Figura 2 - Campo de Forças do Modelo de Campo Psicológico de Kurt Lewin.

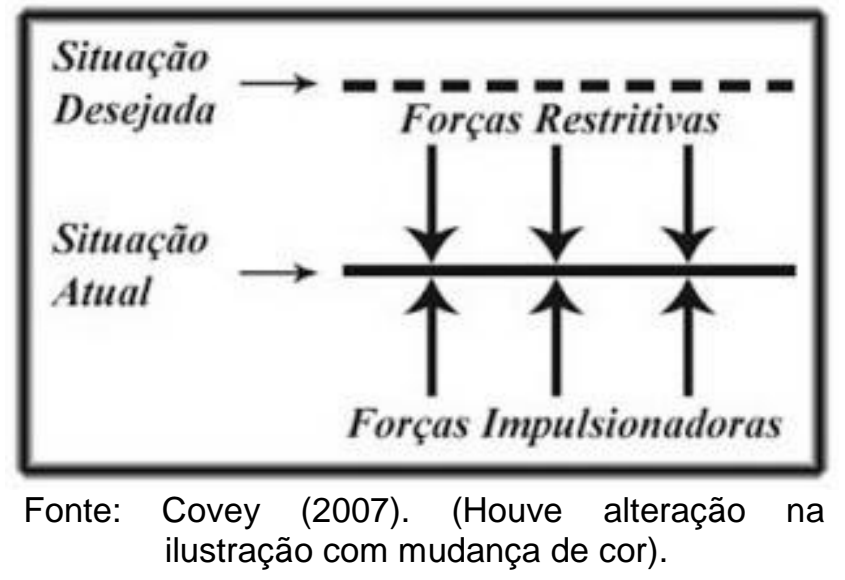

Segundo Covey (2007), na dinâmica do processo de mudança Lewiniana, a linha contínua ilustra o atual nível de desempenho ou atividade; a linha tracejada ilustra o nível almejado, referente ao objetivo do esforço de mudança; as setas direcionadas para baixo são as forças restritivas, ou de resistência ou ainda de desencorajamento; as setas direcionadas para cima são as forças propulsoras, impulsionadoras ou encorajadoras; o nível atual representa o estado de equilíbrio entre as duas forças: restritivas e impulsionadoras. De acordo com o autor, para que a mudança ocorra de forma adequada, é importante conhecer bem ambas as forças.

As forças propulsoras investigadas neste trabalho correspondem aos facilitadores do controle da Dengue, ao passo que as forças restritivas ou retratoras representam os dificultadores para a contenção do agravo. Entende-se que conhecer os significados da Dengue, bem como o campo de forças para o seu controle seja importante para o enfrentamento do problema. As interpretações da realidade cotidiana analisadas em maior profundidade podem contribuir para a compreensão de aspectos subjetivos que corroboram para a manutenção da Dengue como problema social que impacta na saúde púbica. 


\section{REFERENCIAL TEÓRICO-METODOLÓGICO}

Pressupor que os indivíduos e os grupos pensam e que as instituições e a sociedade são ambientes pensantes muda a forma de enxergar as organizações sociais e os comportamentos individuais e coletivos. As pessoas não apenas recebem e processam informação, elas também constroem significados e teorizam a realidade social (VALA, 2004).

Aguiar (2012) apresenta que a própria atividade humana é continuamente significada. Ao discorrer sobre a construção do pensamento e da linguagem, a autora explica que os significados são produções históricas e sociais que permitem a comunicação e a socialização de nossas experiências.

É nessa perspectiva da Psicologia Social do conhecimento cotidiano, dos significados e das Representações Sociais (RS) que serão abordados neste capítulo a Teoria das Representações Sociais (TRS) e o método do Discurso do Sujeito Coletivo (DSC).

\subsection{TEORIA DAS REPRESENTAÇÕES SOCIAIS (TRS)}

A Teoria da Representações Sociais (TRS) foi bastante difundida na França no século XIX. Historicamente reconhecido como pioneiro no tratamento conceitual das representações sociais, o sociólogo, psicólogo social e filósofo francês Émile Durkheim utilizou a expressão representações coletivas para reportar categorias de pensamento por meio das quais uma determinada sociedade elabora e expressa sua realidade. Para ele, as representações coletivas revelam a maneira como o grupo se vê nas relações entre seus membros e os objetos com os quais interagem. Desse ponto de vista sociológico, é a sociedade que pensa; consideradas dessa forma, as representações nem sempre são conscientes no âmbito individual (DURKHEIM, 1897/2000; MINAYO, 2010).

Segundo Durkheim, algumas representações exercem determinada coerção para que seus membros atuem em certo sentido, como por exemplo, a religião e a moral. Embora suas ideias sobre representações sociais tenham sido consensuadas por diversos estudiosos, a visão de objetividade positivista e o quase absoluto poder de coerção que a sociedade exerceria sobre os indivíduos são alvos de críticas dentre certas correntes das ciências sociais (MINAYO, 2010). De qualquer forma, 
importa lembrar que representações sociais na perspectiva da sociologia "é uma expressão filosófica que significa a reprodução de uma percepção anterior da realidade ou do conteúdo do pensamento" (MINAYO, 2010, p. 219).

Já o psicólogo romeno radicado na França Serge Moscovici, empregou o termo Representações Sociais, na década de 1960, na área da Psicologia Social. Para ele, a noção de representação coletiva de Durkheim identificava uma categoria coletiva que deveria ser explicada no nível da psicologia social (FARR, 1994). A psicologia social das representações sociais parte do questionamento das teorias que desconsideram o indivíduo como ser pensante - ou que não valorizam o peso do pensamento individual na constituição da sociedade - e da crítica aos referenciais que ignoram o contexto social em que os indivíduos pensam - bem como a importância desse espaço na elaboração do pensamento (VALA, 2004).

De acordo com Farr (1994), "a escolha de um ancestral", ou seja, a adoção de um estudioso anterior de dado campo particular de pesquisa como sua referência teórica, constitui num compromisso de opção e quase nunca é uma ação neutra. Para esse autor, quando Moscovici escolheu Durkheim como seu "ancestral", foi nitidamente sinalizada a ideia de conexão entre passado e presente, visto que existe clara continuidade entre o estudo das representações coletivas da abordagem sociológica e o estudo mais moderno das representações sociais da perspectiva psicológica.

Entretanto, embora complementares, Castro (2002) e Lima (2013) apontam como diferença importante entre as duas abordagens o fato de as representações coletivas de Durkheim serem estudadas como ideias imutáveis e condutas cristalizadas em tradições, ao passo que as representações sociais de Moscovici se ocupavam com o estudo de fenômenos atuais, que ainda não haviam sedimentado totalmente - tendo em vista o fator temporal e a diversidade do pensamento.

A principal obra que materializou a coleção de pensamentos de Moscovici sobre a TRS foi sua tese intitulada "A Representação Social da Psicanálise" (MOSCOVICI, 1978). Nesse trabalho, Serge conduziu um estudo com o objetivo de compreender, de maneira mais profunda, como a Psicanálise era ressignificada pelos grupos populares quando saíam dos grupos restritos. A principal motivação do autor de pesquisar as RS numa abordagem científica foi sua crítica aos referenciais positivistas que se configuravam insuficientes para explicar a realidade em outras dimensões, como a histórico-crítica (OLIVEIRA; WERBA, 2012). 
Assim, de acordo com Moscovici, as Representações Sociais - que podem ser entendidas como uma forma de conhecimento social ou pensamento social ampliado - correspondem ao modo de interpretação dos objetos, das situações, dos eventos reais do dia a dia. Tais representações circulam, cruzam, concretizam pela fala, pelos gestos, pelos encontros do cotidiano e associam a atividade mental desenvolvida para se posicionar em relação a objetos, sujeitos, situações, informações (MOSCOVICI, 1978; SILVA, 2012).

Dessa forma, as representações com as quais Moscovici se ocupava não eram coletivas nem se impunham às pessoas por via da organização da sociedade; eram, todavia, representações do universo interior, influenciadas e acompanhadas por características que the permitiam ser denominadas sociais. Assim, a proposta de Moscovici é de que as representações constituem um conjunto de proposições, ações, e avaliações emitidas pela opinião pública, que se organizam de diversas formas em conformidade com as classes, com as culturas ou com os grupos (MOSCOVICI, 1978; CASTRO, 2002; LIMA, 2013).

Sob a concepção de Jodelet (1989) e em concordância com Moscovici (1978), Representação Social é a representação de algo, ou de alguém, que corresponde ao conhecimento socialmente elaborado e partilhado. Para eles, as RS, numa visão mais prática, correspondem a significações, a referências para interpretar, para classificar algo com o qual se tem contato; ou seja, é a construção da realidade comum a um conjunto social. Nesse contexto, clarificado por Silva (2012), a RS constitui algo natural, presente nas palavras, nas mensagens, nas imagens da mídia; cristalizadas de forma não definitiva nas condutas e em organizações materiais e espaciais.

Spink (1993) apresenta a RS como um conceito transdisciplinar; de maneira convergente, Silva (2012) expõe que, ao intercambiar diversas áreas do saber, as RS constroem o conhecimento a partir de um "mix" das histórias pessoais e sociais. Assim, são estudadas por meio da consideração de elementos afetivos, mentais, sociais que permeiam os processos de cognição, de linguagem, de comunicação e de relações sociais. Em tais interações é que são elaboradas as representações da realidade material, social e ideal.

Apesar da contextualização histórica e das definições clássicas, compreender o conceito de Representações Sociais (RS) não constitui incumbência tão elementar quanto possa parecer. Ainda mais ao se considerar que o próprio referencial, a 
Teoria das Representações Sociais (TRS), é descrita por diversos estudiosos como dinâmico e não definitivo. Oliveira e Werba (2012), por exemplo, ilustram que as RS podem ser comparadas à "utopia", uma vez que dificilmente se chega ao seu limite; segundo tais autores, quando o estudioso se aproxima desse conceito, o mesmo parece situar-se ainda mais distante, o que obriga o pesquisador a superar os próprios limites em busca do "horizonte/conceito perdido".

Explicando as razões não-históricas que caracterizam essa difícil apreensão dos aspectos conceituais das RS, Moscovici (1978), bem lembrado por Farr (1994) e Silva (2012), apresenta a própria situação do conceito na dialética - e por que não dizer, encruzilhada - entre o campo da sociologia e o da psicologia. Parte desse desafio se dá também em virtude da própria natureza das RS, que se modificam quando novos significados são acrescentados à realidade. Todavia, esse movimento é importante, considerando-se que proporciona aos teóricos, acadêmicos e demais interessados, novas perspectivas, entendimentos e interpretações dos fenômenos sociais, o que auxilia na compreensão do por que os indivíduos agem como agem (OLIVEIRA; WERBA, 2012).

Segundo Oliveira e Werba (2012), essa mesma dinamicidade e historicidade são as características mais importantes que distinguem a RS de outros conceitos. Oliveira e Werba (2012) explicam, nesse sentido, que as representações sociais estão associadas às práticas culturais e que dão conta da flexibilidade da realidade contemporânea, sem deixar de lado, todavia, toda a carga histórica e o peso da tradição. Para esses autores, tal diferencial delineia as RS como estruturas simbólicas esculpidas tanto pela duração e pela manutenção como pela inovação e pela metamorfose. Essa compreensão vai ao encontro das considerações de Moscovici, bem lembradas por Silva (2012), sobre o fato de as RS se ocuparem das transformações e permanências sociais.

As RS se diferenciam ainda de outras teorias de tendência positivista e funcionalista por aceitarem os achados contraditórios; em outras palavras, os pesquisadores não descartam os conteúdos conflitantes; é exatamente o oposto, "a possibilidade de trabalhar com as diferenças que enriquece a compreensão do fenômeno investigado, conferindo à teoria das RS uma dimensão dialética" (OLIVEIRA; WERBA, 2012, p. 110). Esse aspecto é corroborado por Jodelet (2005) e por Silva (2012), ao apresentarem que na TRS o mundo social serve de apoio e, 
por assim ser, tanto as convergências quanto os conflitos contribuem para a construção das RS.

A despeito da complexidade conceitual que envolve a Teoria das Representações Sociais, Lefrevre et al. (2007), esquematizando o exposto por Alexandre (2004), definem de forma mais palatável Representações Sociais como:

[...] o conhecimento associado à vida cotidiana das pessoas, que é elaborado em sociedade e que tem por função servir de instrumento para que os atores sociais possam interpretar, pensar e agir sobre a realidade. Tal conhecimento é estruturado tanto individualmente quanto socialmente e transmitido desde o nascimento, incorporando valores, motivações e normas de nosso ambiente social [...] (LEFREVRE et al., 2007, p. 1698).

No que se refere aos fundamentos das representações sociais, Spink (1993), Jodelet (2005) e Silva (2012) apresentam as RS de duas formas: como campo socialmente estruturado e como núcleo estruturante da ação. O campo socialmente estruturado tem a ver com a contribuição de determinado espaço, segmento, grupo, extrato social, categoria profissional para a elaboração das representações. Ou seja, procura conhecer as experiências individuais que compõem o pensamento coletivo de certa comunidade e as interpretações que constroem da realidade daquele campo social. Por outro lado, as RS, vistas como núcleo estruturante da ação, relacionam-se com a ideia do sujeito como produtor de sentido; neste contexto, suas representações expressam os sentidos e significações que ele atribui à sua experiência no mundo social.

As RS como um conjunto de conceitos, de explicações, de afirmações do cotidiano, a partir das comunicações, apresentam duas formas de representar o mundo por meio da consciência: a direta - quando o objeto é perceptível, está presente - e a indireta, quando o objeto está ausente e é preciso simulá-lo. Entretanto, seja pela forma direta, seja pelo modo indireto, as RS partem sempre da diversidade individual e coletiva para a construção de um mundo estável, previsível (SILVA, 2012).

A possível interligação entre cognição, afeto e ação no processo de representação é que constitui um dos elementos mais importantes da TRS. Na concepção da representação como um processo mental, entende-se que as RS carregam sempre um sentido simbólico (OLIVEIRA; WERBA, 2012). Dessa maneira, 
o processo de formação das RS traduz duas realidades inseparáveis: o lado simbólico/icônico; e o lado figurativo das RS (SILVA, 2012).

A faceta simbólica tem a ver com a atribuição de significado pautada num contato menos profundo com o objeto, quando os elementos para a elaboração do seu significado foram adquiridos por meio da associação de imagens, textos, símbolos, sons, tatos e demais sentidos a seus respectivos nomes, características definidoras e funções no cotidiano.

Por exemplo, se uma pessoa adentra uma sala portando um jaleco branco, o que se pode interpretar quase que de forma automática? Possivelmente, que esse indivíduo usa tal vestimenta como um uniforme de trabalho e que sinaliza para a possibilidade de o mesmo ser um médico, farmacêutico, enfermeiro, professor, açougueiro, pipoqueiro e assim por diante. O jaleco branco, nesse caso, pode ser um sinal, um indicativo de algumas hipóteses que relacionam o objeto observado à ocupação laboral da pessoa. Agora, imagine-se que nesse mesmo uniforme seja identificado um logotipo composto por uma lâmpada, uma cobra e uma cruz bordadas no bolso, o que essas formas significam? Quem tiver assistido, lido ou ouvido a história da enfermagem, não terá dificuldades para identificar aquela pessoa como um(a) enfermeiro(a), visto que o conjunto de símbolos mencionados compõe o símbolo da profissão.

Já no lado figurativo das RS, a atribuição de significado ocorre por meio da experiência individual com o fenômeno de interesse. Dessa forma, a representação elaborada a partir da figuração tende a ser profunda, rica, robusta, preenchida de sentimentos evocados na memória de quem vivenciou a situação, interagiu com o objeto, teve uma percepção registrada por diversos órgãos e sentidos.

Imagine-se, como exemplo, que, numa entrevista, seja perguntado a um morador da comunidade que nunca portou Dengue: o que significa Dengue para você? Possivelmente, seu depoimento seria elaborado e expresso por definições, opiniões, conceitos oriundos do conhecimento científico e/ou do senso-comum. Mas se a mesma questão fosse apresentada para essa pessoa após quadro febril e álgico, seguido por complicações e de internação devido à manifestação da doença, seu discurso seria construído também com base nas percepções experienciadas de quem foi acometido pela enfermidade, de quem vivenciou os aspectos bio-psicosociais desse processo saúde-doença. Embora não excluísse a faceta simbólica, uma vez que simbolismo e figuração são intercomplementares, os aspectos 
figurativos dariam corpo diferenciado às representações sobre a Dengue daquele indivíduo.

De qualquer forma, seja pela evocação da realidade simbólica/icônica ou pelo acesso à elaboração figurativa, as pessoas processam as RS para tornar familiar o não familiar. Portanto, para discorrer sobre esse processo de familiarização, tornase, primeiro, necessário compreender duas classes ou tipos distintos de universos de pensamento existentes nas sociedades contemporâneas: os Universos Consensuais (UC) e os Universos Reificados (UR) (MOSCOVICI, 2004; LEITE; VELOSO, 2008; OLIVEIRA; WERBA, 2012).

Nos UR - que são restritos - circulam as ciências, a objetividade, o rigor lógico e metodológico ou as teorizações abstratas; já nos UC - que correspondem às teorias do senso comum - acontecem as práticas interativas do dia a dia e a própria produção das representações sociais. Apesar de tais diferenças, ambos os universos de pensamento se entrelaçam dialeticamente na origem e na formação das representações (MOSCOVICI, 2004; LEITE; VELOSO, 2008; OLIVEIRA; WERBA, 2012).

De acordo com a TRS, o posicionamento simbólico, que transforma conhecimento científico em senso-comum, se dá por meio da ancoragem e da objetivação, que são dois processos de familiarização e de materialização do objeto, da situação ou do evento com o qual se tem contato (SPINK, 1993; JODELET, 2005).

A ancoragem ou ancoração pode ser entendida como o trabalho mental de tornar familiar o que até então era estranho, por meio de classificações e categorizações prévias, próprias. Ou seja, a atividade de classificar e denominar coisas inexistentes, que causam estranhamento, a partir de sistemas pessoais de agrupamentos de ideias pré-consolidadas interiormente (SPINK, 1993; JODELET, 2005).

A objetivação, por sua vez, constitui na elaboração de tornar concreto o que é abstrato; de transformar um conceito em algo real, material. Em outras palavras, é reproduzir um conceito em uma imagem; implica descobrir a qualidade simbólica de uma ideia imprecisa. Dessa forma, a ancoragem corresponde à integração cognitiva do objeto representado; e a objetivação relaciona-se com a construção formal do conhecimento; sendo que ambas se completam no dinâmico processo de formação das representações sociais (SPINK, 1993; JODELET, 2005). 
Reis e Bellini (2011), ao discorrerem sobre a aplicação da teoria e sobre procedimentos metodológicos das Representações Sociais (RS), relembram quatro funções importantes, elencadas por Abric (2000) como sustentáculos das RS. A primeira é a função de saber - por meio da qual se permite compreender e explicar a realidade; a segunda é a função identitária - porque define a identidade e permite a proteção da especificidade dos grupos; já a terceira função é a de orientação - uma vez que guia os comportamentos e as práticas; e a quarta função, a função justificadora - pela qual as representações permitem a justificativa das tomadas de posição e dos comportamentos. Dessa forma, as RS desempenham uma contribuição valiosa para a formação de condutas, uma vez que orientam relações e comunicações na sociedade (REIS; BELLINI, 2011).

Segundo Jodelet (1989) e Spink (1993), a RS constitui uma forma de conhecimento prático; que é o saber do senso-comum. Essa compreensão é compartilhada por Oliveira e Werba (2012) que destacam como contribuição importante da TRS a alocação dos saberes do senso comum em uma categoria científica; para eles, ao valorizar o conhecimento popular, a TRS tornou factível e importante sua investigação.

Lefevre e Lefevre (2012) complementam tal aspecto versando sobre a possibilidade de se obterem as representações por meio da investigação de saberes e informações literárias, da narrativa, da arte, de textos científicos, escolares, do senso-comum, jornalísticos e religiosos. Dessa forma, as RS estão disponíveis nos meios de comunicação de massa, na mídia, na internet, na igreja, nos museus, em áreas de trabalho e na unidade familiar.

Segundo Moscovici, a representação social, expressa na forma de opinião, pode ser considerada uma "preparação da ação", ou seja, um comportamento em miniatura, uma atitude provável. Por esse motivo, o autor atribui à opinião uma qualidade preditiva, considerando que, "segundo o que um indivíduo diz, pode-se deduzir o que ele vai fazer" (MOSCOVICI, 1978, p. 46). A seguir esse aspecto da associação indivíduo-ação explícito nas palavras do autor:

[...] quando exprime sua opinião sobre um objeto, somos levados a supor que ele já se representou algo desse objeto, que o estímulo e a resposta se formam em conjunto. Quer dizer, a resposta não é uma reação ao estímulo, mas, até certo ponto, está na sua origem. O estímulo é determinado pela resposta [...] (MOSCOVICI, 1978, p. 48). 
Os pontos de vista dos indivíduos e grupos também podem ser observados a partir de suas características de comunicação e de expressão. Para Mocovici, "as imagens, opiniões, são comumente apresentadas, estudadas e pensadas tãosomente na medida em que traduzem a posição e a escala de valores de um indivíduo ou de uma coletividade" (MOSCOVICl, 1978, p. 49). Segundo Lefevre e Lefevre (2012), as RS permitem às pessoas ver as coisas como suas: em minha opinião, na minha óptica, no meu ponto de vista, a meu ver e assim por diante.

Oliveira e Werba (2012) descrevem ainda três enfoques, apontados por De Rosa (1994) como níveis de discussão e análise das RS: o nível fenomenológico, o teórico e o metateórico. Segundo tais autores, no nível fenomenológico, as RS são objetos de investigação, ou seja, estudam-se elementos da realidade social, formas de conhecimento, saberes do senso-comum que permeiam as relações interpessoais do dia a dia, visando compreender e controlar a realidade social. Já o nível teórico, constitui o conjunto de definições conceituais e metodológicas, construtos, generalizações e proposições referentes às RS. E, por fim, o nível metateórico representa o nível das discussões, de debates, de refutações críticas e de comparações sobre a teoria em si.

Nesse sentido, esta pesquisa sobre os significados da Dengue para os Enfermeiros da APS de Alfenas situa-se no nível fenomenológico de discussão e análise das representações sociais, em que as RS destes atores sociais sobre a doença constituíram o objeto de investigação. Uma vez apresentado o arcabouço teórico, abrir-se-á espaço para indicar qual foi o conjunto de instrumentos, ou seja, a técnica utilizada para a exploração, para a análise e para a interpretação dos dados qualitativos emersos dos depoimentos individuais: o método do Discurso do Sujeito Coletivo (DSC), que se baseia nas fontes ora apresentadas da Teoria das Representações Sociais (TRS).

\subsection{DISCURSO DO SUJEITO COLETIVO (DSC)}

O DSC é uma técnica de tabulação e de organização de dados qualitativos, em desenvolvimento na Universidade de São Paulo desde a década de 1990 que, fundamentado nos pressupostos da Teoria das Representações Sociais, permite conhecer os significados, os pensamentos, as opiniões, as representações, as crenças e os valores de uma coletividade sobre determinado tema; para tal, agrega 
ao referencial teórico procedimentos sistemáticos e padronizados que the atribuem reconhecido caráter científico inovador (LEFEVRE, LEFEVRE, 2003a; 2003b; 2005; 2012; FIGUEIREDO; CHIARI; GOULART, 2013).

De acordo com Lefevre e Lefevre (2003b; 2005; 2012) e Figueiredo, Chiari e Goulart (2013), a técnica consiste basicamente em analisar o material coletado em pesquisas que tem depoimentos verbais, textos, imagens, notícias como sua matéria prima, extraindo-se, de cada um destes, partes de discursos de sentido semelhante por meio do qual torna-se possível agregar depoimentos sem reduzi-los a quantidades.

Para a produção dos DSC, é necessário trabalhar com quatro operadores, também denominadas por Lefevre e Lefevre (2012) como figuras metodológicas, a saber: 1) as Expressões-Chave (E-Ch), 2) as Ideias-Centrais (ICs), 3) as Ancoragens (ACs), e 4) os Discursos do Sujeito Coletivo (DSCs) propriamente ditos. Pensando na estrutura, no processo e no resultado, o Discurso do Sujeito Coletivo pode ser entendido como uma reunião de Expressões-Chave (E-Ch) que possuem em comum a mesma Ideia-Central (IC) ou Ancoragem (AC), num só discurso síntese, redigido na primeira pessoa do singular.

A forma peculiar de apresentação do DSC objetiva causar no receptor o efeito de uma opinião coletiva, sendo expressa de forma direta, como que pela boca de um único sujeito, no caso, um sujeito artificial falando sobre um fato empírico. No caso dos significados da Dengue deste estudo, por exemplo, o "eu coletivo" se expressará por intermédio da figura simbólica do "Enfermeiro da Atenção Primária à Saúde de Alfenas". Em outras palavras, o DSC constitui uma técnica de pesquisa qualitativa criada para fazer uma coletividade falar, como se fosse um só indivíduo (LEFEVRE; LEFEVRE, 2003b; 2012).

Além dessas figuras metodológicas para a análise qualitativa, devem-se considerar também dois atributos quantitativos: 1) a Intensidade/força e, 2) a Amplitude (LEFEVRE; LEFEVRE, 2012). O primeiro, intensidade, refere-se:

[...] ao número ou percentual de indivíduos que contribuíram com suas Expressões-Chave relativas às Ideias Centrais ou Ancoragens semelhantes ou complementares, para a construção de um dado Discurso do Sujeito Coletivo [...] (LEFEVRE; LEFEVRE, 2012, p. 82). 
Já o segundo atributo quantitativo, a amplitude, revela 0 grau de espelhamento ou de difusão de uma ideia no Campo pesquisado, tendo a ver, assim, com a: "medida da presença de uma ideia ou representação social considerando o campo ou o universo pesquisado" (LEFEVRE; LEFEVRE, 2012, p. 83).

Conforme descrição detalhada de Silva (2012), baseada em Lefevre e Lefevre (2005), será reproduzido o passo a passo do trabalho de construção dos DCSs; segundo tais autores, após a transcrição das entrevistas gravadas, deve-se proceder à tabulação dos dados. Para tal, cada questão deve ser analisada separadamente, ou seja, primeiro será analisada a questão 1 de todos os Enfermeiros depoentes; em seguida a questão 2, e assim por diante. Logo, eis os passos a serem seguidos:

- passo 1: transferir cópia na íntegra de todas as respostas dadas à questão 1 para o Instrumento de Análise do Discurso 1 (IAD1), na coluna E-Ch do quadro de apresentação;

- passo 2: Identificar e destacar - com algum recurso gráfico (como determinada cor ou sublinhado, por exemplo) - as E-Ch e ACs das IC no conteúdo das respostas;

- passo 3: Identificar as IC e, quando houver, as AC, a partir das E-Ch, colocando-as nas caselas específicas do quadro construído;

- passo 4: Identificar e agrupar as IC e as AC de mesmo sentido ou sentido equivalente ou complementar. Deve-se "carimbar" cada grupo: A, B, C e assim por diante;

- passo 5: Nomear cada agrupamento A, B, C, D e outros, o que de outra forma pode ser entendido como criar uma ideia central ou ancoragem síntese que expressem todas as ICs e ACs de mesmo sentido;

- $\quad$ passo 6: Construir o DSC. Para isso, sugere-se a utilização do IAD2 Instrumento de Análise de Discurso 2. Deve-se elaborar um DSC para cada agrupamento identificado no passo 5; assim, devem ser utilizados tantos IAD2s quantos forem necessários.

Portanto, a forma de elaborar o DSC, apontada por Silva (2012) e adotada para esse trabalho, divide-se em duas fases: a primeira etapa consiste em transferir 
cópia de todas as E-Ch do mesmo agrupamento presentes no IAD1 para a coluna das E-Ch do IAD2; já o segundo estágio, diz respeito à construção de todos os DCSs propriamente ditos. 


\section{REPRESENTAÇÕES SOCIAIS SOBRE A DENGUE}

Dentre o conjunto de trabalhos relacionados às representações sociais sobre a Dengue disponíveis na literatura, notam-se registros sobre o que pensam populações de áreas expostas ao vetor e com registros de casos de Dengue; representações de profissionais de saúde como Agentes de Controle de Endemias (ACE), Agentes Comunitários de Saúde, Médicos, Enfermeiros e Auxiliares de Enfermagem da Estratégia Saúde da Família (ESF); opiniões de estudantes de graduação; bem como análises documentais de materiais educativos impressos e reportagens de jornais e revistas sobre a doença.

Num estudo cujo objetivo principal foi saber como cuidadores de plantas representam as relações entre vasos e criadouros de vetores da Dengue, por exemplo, os autores registraram informações errôneas no imaginário da população; e descrença de que um simples mosquitinho possa causar tanto problema, como ideias negativas. Já como representações positivas, foram observadas: entendimento do mecanismo básico de transmissão da doença; valorização do papel e da presença constante da autoridade sanitária; entendimento da parcela de responsabilidade que cabe à população no enfrentamento à doença. Em relação às ações de controle do vetor da Dengue, pôde-se notar que as mensagens educativas curtas emitidas pelas autoridades sanitárias não colaboraram para a assimilação comunitária esperada (LEFEVRE et al., 2004).

Já noutro trabalho sobre representações da Dengue, seu vetor e ações de controle por moradores do município de São Sebastião-SP (LEFEVRE et al., 2007), os discursos revelaram que a população não está conseguindo discriminar adequadamente o tipo ou modalidade de coleção de água mais apropriada para a criação do mosquito e que desconhece a fase de ovo no desenvolvimento do vetor. Os autores identificaram consciência inadequada da relação de vários elementos da biologia do vetor, bem como da necessária integração entre poder público e a população. Com isso, sugeriram que o conhecimento sobre tais representações servisse de insumo para a reorientação de atividades educativas e melhoria das ações participativas de combate à Dengue e ao controle do vetor.

Outro exemplo foi uma dissertação de mestrado que buscou investigar as representações sociais das mulheres residentes e dos ACSs de Aparecida-SP sobre a Dengue e o vetor Aedes aegypti. Nesse estudo, Ribeiro (2008) identificou que 
tanto os Agentes Comunitários de Saúde (ACSs) quanto a população definiram a reprodução do mosquito relacionada à água, porém houve confusão sobre qual o tipo mais adequado à reprodução. Na visão das mulheres, a população precisaria colaborar mais nas atividades de controle, porém a responsabilidade foi atribuída ao governo. Já os Agentes, revelaram a necessidade de conscientização da população quanto às responsabilidades e se mostraram confusos em relação ao papel do governo. Discutindo crença, responsabilidade e comunicação sobre a Dengue, foi pontuada ainda a importância da contribuição dos moradores e a necessidade de melhoria do treinamento e da formação dos ACSs.

Compreender as estratégias de prevenção e de controle da Dengue em Sabará/MG foi o objetivo de outra dissertação de mestrado (OLIVEIRA, 2012), apresentada na forma de dois artigos científicos. No primeiro trabalho, referente à análise de conteúdo de 28 materiais educativos impressos (MEI) de Dengue que circulam no Município, a pesquisadora notou que as mensagens abordaram o ensino sobre a transmissão por meio de prescrições e de recomendações verticalizadas, o que, segunda ela, não valoriza o diálogo, a liberdade e a autonomia dos leitores. Ainda foi ressaltado como importante que os profissionais de saúde fiquem atentos à qualidade dos recursos pedagógicos utilizados nas atividades de educação em saúde.

No segundo estudo apresentado na dissertação, que focou nas representações sociais de 19 ACE sobre as estratégias empregadas na prevenção e no controle da Dengue, pôde-se perceber que os agentes: reconhecem a importância do seu trabalho e culpam a população pela ocorrência da doença; consideram como umas das principais estratégias de enfrentamento à doença a conversa diária que têm com o morador (ação educativa); entendem as parcerias entre poder público e instituições como uma das ações necessárias para a responsabilização dos serviços de saúde e a sociedade. Concluiu-se que é necessário investimento na educação permanente dos ACE para garantir-lhes atribuições de eficiência e qualidade (OLIVEIRA, 2012).

No contexto da Atenção Primária à Saúde, um estudo das representações sociais de profissionais de unidades de saúde da família, sobre os fatores contribuintes para a ocorrência da Dengue, registrou os seguintes discursos dentre médicos, Enfermeiros e auxiliares de enfermagem: falta de cuidado da população com o ambiente em que vive; descrédito da população na ocorrência e na gravidade 
da doença; qualidade dos serviços diretos e dos relacionados ao controle do Dengue; influência das classes sociais na ocorrência e no controle do Dengue. Os profissionais entrevistados atribuíram à população parte importante da responsabilidade pela ocorrência do Dengue, observaram a falta de estrutura e de organização dos serviços e perceberam dificuldades para a mudança dos comportamentos observados. Considerou-se importante a divulgação das percepções dos profissionais em relação a conceitos equivocados, para haver valorização da capacitação. Além disso, os autores assinalam a relevância da implantação de metodologias que impactem no comportamento de todos na prevenção e no combate à Dengue. Os pesquisadores concluíram que os discursos obtidos mostram a importância de uma mudança de conduta dos gestores, que considere a opinião de profissionais e de usuários e que discuta conceitos pouco trabalhados nos cursos da área de saúde, para conseguir impactar conduta (REIS; ANDRADE; CUNHA, 2013).

Reflexões importantes sobre a mediação da informação em saúde pública foi a contribuição de um estudo das representações sociais sobre Dengue, envolvendo estudantes de graduação em Ciências da Informação e da Documentação. Tal experiência fê-los pensar sobre a importância do esclarecimento sobre a diferença entre informação e comunicação. Além disso, segundo os autores, para haver circulação e apropriação da informação em Saúde Pública, é imprescindível abrir espaço para a sociedade se expressar a respeito; bem como discutir como o cidadão enxerga a informação sobre saúde e quais valores ele atribui à mesma. Daí a importância das representações sociais nesse processo de conhecimento baseado na análise do discurso (VILLELA; ALMEIDA, 2013).

Já num trabalho sobre mídia, saúde, poder e representações sobre Dengue é possível conhecer como a primeira epidemia de Dengue em Ribeirão Preto-SP foi abordada pela mídia impressa. Para os pesquisadores, tal meio de comunicação mais polemizou com a discussão sobre quem seria o grande vilão da epidemia do que esclareceu sobre a epidemia em si. O subtema mais apresentado foi o papel das autoridades políticas e sanitárias, que, segundo os autores, não contribuem para aprimorar o conhecimento popular sobre a doença, não possibilita a prevenção, nem estimula a comunidade com comportamentos que auxiliem no controle da doença. Foi apresentado ainda que houve defasagem da informação disponibilizada e jogo de representações, em que a relação mídia/poder ficaram nítidas. Os estudiosos 
consideraram que é importante discutir a qual tipo de informação o cidadão tem acesso durante os processos epidêmicos, se a informação política ou a epidemiológica. Para eles, as questões políticas não podem se sobrepor às questões prioritárias de saúde nos meios de comunicação que alcançam as famílias (VILLELA; NATAL, 2014).

Analisando os exemplos de trabalhos supracitados, pode-se notar que 0 interesse na compreensão das representações sociais sobre a doença tem sido orientado por objetivos acadêmicos, mas também para fins estratégicos e de planejamento da práxis, em que pesquisadores, gestores e profissionais de saúde pública buscam subsídios para uma reorientação de atividades de educação continuada e de educação em serviço, visando avanços na participação popular e no controle social do mosquito Aedes aegypti. Entretanto, chama a atenção o número reduzido de contribuições abordando as representações sociais sobre a Dengue, o que sugere a necessidade de incremento de estudos dessa natureza. 


\section{MATERIAL E MÉTODOS}

\subsection{TIPO DE ESTUDO}

Tratou-se de uma Pesquisa Social em Saúde (MINAYO, 2010, p. 47), do tipo Pesquisa de Representação Social, de abordagem qualitativa (LEFEVRE; LEFEVRE, 2012). Pesquisa Social em Saúde contempla "todas as investigações que tratam do fenômeno saúde/doença, sua representação pelos vários atores que atuam no campo: as instituições políticas e de serviços e os profissionais e usuários" (MINAYO, 2010, p. 47).

\subsection{PROBLEMA E PERGUNTA DE PESQUISA}

Foi apresentado como problema de pesquisa o fato de a Dengue continuar resistindo às tentativas de controle e de persistir impactando nos contexto social e de saúde da população.

Considerando que o enfrentamento da Dengue está intimamente relacionado ao comportamento individual e às ações coletivas, de forma dialética, é que se perguntou: Quais são os significados da Dengue para os Enfermeiros da Atenção Primária à Saúde de Alfenas? Quais são as forças restritivas e propulsoras para o controle da Dengue, segundo a perspectiva desses profissionais?

\subsection{ATORES, CAMPO SOCIAL E LUGAR DO ESTUDO}

Os atores/agentes sociais deste trabalho foram constituídos por 17 Enfermeiros, atuantes nas Unidades Básicas de Saúde (UBS) e Equipes da Estratégia Saúde na Família (ESF) - campo social do estudo, e que integram a Rede de Atenção Primária à Saúde (APS) do Município de Alfenas/MG - lugar da pesquisa. Segundo o Censo Demográfico realizado em 2010, Alfenas-MG contava com: população residente de 73.774 pessoas, unidade territorial com área de $850,446 \mathrm{Km}^{2}$, e densidade demográfica de $86,75 \mathrm{hab} / \mathrm{Km}^{2}$ (IBGE, 2013). 
O total de entrevistados correspondeu à população de estudo. Assim, foram adotados os seguintes critérios de inclusão: 1) ser Enfermeiro; 2) trabalhar na Atenção Primária à Saúde de Alfenas-MG; e 3) aceitar participar da pesquisa.

Neste trabalho, não foi empregado critério de saturação, uma vez que tal procedimento não é recomendado para o Método do Discurso do Sujeito Coletivo DSC (LEFEVRE; LEFEVRE, 2012).

\subsection{COLETA DE DADOS}

Para a coleta de dados, foram realizadas entrevistas individuais, devido à compreensão das mesmas como técnica privilegiada de comunicação que gera excelente oportunidade de exteriorização de opiniões (MINAYO, 2010; LEFEVRE; LEFEVRE, 2012).

A abordagem dos profissionais foi feita no próprio local de trabalho, sujeito a sujeito, entre junho e julho de 2015. Para tal, foi elaborado um formulário de pesquisa contendo duas partes; a primeira, para preenchimento de dados cadastrais do entrevistado, e a segunda, com um roteiro de entrevista semiestruturada, conforme o Apêndice A.

No campo de cadastro, foram preenchidas as seguintes variáveis: código do áudio, data da entrevista, sigla de referência, idade, sexo, tempo de serviço, e se o entrevistado já teve Dengue. Já o roteiro, foi composto por questões formuladas segundo os objetivos de conhecer o que a Dengue significa; e de identificar forças restritivas e propulsoras para o controle dessa doença, segundo o olhar dos Enfermeiros da APS de Alfenas-MG.

A seguir as perguntas contempladas no roteiro:

1. Se uma amiga the perguntasse o que a Dengue significa para você, qual seria a sua resposta?

Objetivo: Conhecer o que a Dengue significa para os Enfermeiros da Atenção Primária à Saúde (APS). 
2. Se essa mesma pessoa the perguntasse ainda: "Para você, o que dificulta o controle da Dengue?" O que você Ihe diria?

Objetivo: Identificar dificuldades (forças retratoras) para o controle da Dengue, segundo a perspectiva dos Enfermeiros da APS.

3. Para você, o que facilita o controle da Dengue?

Objetivo: Identificar facilidades (forças propulsoras) para o controle da doença, de acordo com o olhar dos atores sociais abordados.

Tal roteiro passou por um pré-teste antes da coleta de dados, para o qual foram convidados dois Enfermeiros da população de estudo, escolhidos por conveniência. Essa etapa foi importante para avaliar a compreensão das perguntas pelos sujeitos pesquisados e para analisar se as questões apresentadas atenderiam, de fato, aos objetivos que as nortearam.

Os depoimentos individuais foram registrados com gravador de áudio (digital) e posteriormente transcritos. Como durante o pré-teste não foi observada necessidade de alteração das perguntas, nem dos demais campos do formulário de entrevista, os dois participantes foram mantidos na população de estudo e seus depoimentos foram igualmente considerados na análise dos dados.

\subsection{ORGANIZAÇÃO, EXPLORAÇÃO E ANÁLISE DE DADOS}

Para a organização, para a exploração e para a análise do material foi utilizado o Discurso do Sujeito Coletivo (DSC). O DSC é uma técnica de tabulação e de organização de dados qualitativos que permite, por meio de procedimentos sistemáticos e padronizados, agregar depoimentos sem reduzi-los a quantidades (LEFEVRE; LEFEVRE, 2012; 2005).

A fim de facilitar o estudo e a descrição do que aquela coletividade pensava, foram utilizados dois instrumentos operacionais propostos por Silva (2012): o Instrumento de Análise do Discurso 1 (IAD1) e o IAD2 - Instrumento de Análise de Discurso 2, conforme Anexo D, Anexo $E$ e de acordo os passos para elaboração do DSC, descrito no Capítulo 3 deste trabalho. 


\subsection{ASPECTOS ÉTICOS}

O trabalho teve início após a autorização da coleta de dados pela Secretaria de Saúde da Prefeitura Municipal de Alfenas-MG, conforme Apêndice B, e mediante a aprovação do projeto pelo Comitê de Ética em Pesquisa (Anexo B). Os profissionais convidados a participar do estudo foram orientados sobre os objetivos e informados sobre os direitos e as condições a eles assegurados durante todas as etapas do estudo. Aos indivíduos que aceitaram participar da pesquisa, foram entregues os Termos de Consentimento Livre e Esclarecido para prosseguirem com sua assinatura, conforme apresentado no Apêndice C. 


\section{RESULTADOS}

\subsection{CARACTERÍSTICAS PESSOAIS E PROFISSIONAIS DOS PARTICIPANTES DA PESQUISA}

Os atores sociais que compuseram a população de estudo referem-se a 17 profissionais de nível superior em enfermagem, todas do sexo feminino, cuja média das idades foi de 40 anos.

Em relação ao tempo de experiência profissional, observou-se mediana de 5 anos de atuação na Atenção Primária à Saúde, sendo que 14 destas enfermeiras $(82,35 \%)$ integram Equipes de Saúde da Família (ESF) urbanas, 1 profissional $(5,88 \%)$ atende na ESF da zona rural, e as 2 outras participantes $(11,76 \%)$ trabalham em Ambulatórios de Atenção Básica urbanos.

Destas, 3 entrevistadas (17,64\%) já foram acometidas por Dengue e as 14 demais $(82,35 \%)$ não apresentaram a doença.

\subsection{TEMAS ESTUDADOS, AGRUPAMENTOS, IDEIAS CENTRAIS E DSC}

Após a análise dos dados textuais - por meio de leituras repetidas e exaustivas dos depoimentos individuais, de forma vertical e horizontal, perpassando os passos descritos no tópico 3.2 do presente trabalho -, deu-se sequência com: agrupamento das Ideias Centrais iguais, semelhantes e complementares dos temas de estudo; identificação cronológica e quantificação dos participantes que contribuíram com cada representação; apresentação de figura síntese dos achados; e construção dos respectivos Discursos do Sujeito Coletivo (DSC).

\subsubsection{Tema: Significados da Dengue}

O Quadro 1 inicia a apresentação do processo de obtenção dos Significados da Dengue, segundo a perspectiva das Enfermeiras da Atenção Primária à Saúde de Alfenas-MG. 
Quadro 1 - Agrupamento das Ideias Centrais iguais, semelhantes e complementares do tema: "Significados da Dengue".

\begin{tabular}{|c|c|}
\hline $\begin{array}{c}\text { Ideias Centrais iguais, semelhantes e } \\
\text { complementares }\end{array}$ & IC agrupadas \\
\hline $\begin{array}{l}\text { Algo ruim } \\
\text { Desconforto enorme }\end{array}$ & A - Desconforto enorme \\
\hline $\begin{array}{l}\text { Problema de saúde pública } \\
\text { Um problema de saúde pública } \\
\text { Uma doença de saúde pública } \\
\text { Doença que requer atenção especial, um } \\
\text { problema de saúde pública } \\
\text { Uma questão de Saúde pública }\end{array}$ & $\begin{array}{l}\text { B - Problema de saúde } \\
\text { pública }\end{array}$ \\
\hline $\begin{array}{l}\text { Descuido das pessoas } \\
\text { Doença causada pela falta de cuidado das } \\
\text { pessoas }\end{array}$ & C - Descuido das pessoas \\
\hline $\begin{array}{l}\text { Produto da falta de educação } \\
\text { Consequência da falta de educação }\end{array}$ & $\begin{array}{l}\text { D - Consequência da falta de } \\
\text { educação }\end{array}$ \\
\hline $\begin{array}{l}\text { Doença viral, febril, com sintomas específicos } \\
\text { Doença viral }\end{array}$ & E - Doença viral \\
\hline $\begin{array}{l}\text { Uma preocupação } \\
\text { Preocupação, medo }\end{array}$ & F - Preocupação e medo \\
\hline $\begin{array}{l}\text { Um caso muito grave } \\
\text { Doença grave que eu não gostaria de ter }\end{array}$ & G - Doença grave \\
\hline $\begin{array}{l}\text { Picada do mosquito } \\
\text { Doença causada pelo mosquito que pode levar à } \\
\text { morte }\end{array}$ & $\begin{array}{l}\mathrm{H} \text { - Doença causada pela } \\
\text { picada do mosquito }\end{array}$ \\
\hline Uma epidemia & I - Epidemia \\
\hline $\begin{array}{l}\text { Doença de país pobre } \\
\text { Mais uma doença pra gente cuidar } \\
\text { Uma guerra }\end{array}$ & $\mathrm{J}$ - Outros significados \\
\hline
\end{tabular}

Os agrupamentos de Ideias Centrais que resultaram nos Significados da Dengue são apresentados juntamente com a identificação cronológica e a quantificação dos participantes que contribuíram com cada significação, conforme Quadro 2. 
Quadro 2 - Significados da Dengue, conforme Ideias Centrais, participantes do estudo e frequência.

\begin{tabular}{|l|c|c|}
\hline \multicolumn{1}{|c|}{ Significados } & Participantes & Frequência \\
\hline A - Desconforto enorme & 1 e 13 & 2 \\
\hline B - Problema de saúde pública & $3,7,9,12$ e 15 & 5 \\
\hline C - Descuido das pessoas & 2 e 5 & 2 \\
\hline D - Consequência da falta de educação & 5 e 17 & 2 \\
\hline E - Doença viral & 7 e 11 & 2 \\
\hline F - Preocupação e medo & 4 e 16 & 2 \\
\hline G - Doença grave & 3 e 10 & 2 \\
\hline H - Doença causada pela picada do mosquito & 6 e 8 & 2 \\
\hline I- Epidemia & 14 & 1 \\
\hline J - Outros significados & 10,1 e 14 & 3 \\
\hline \multicolumn{2}{|c|}{ Total } & 23 \\
\hline
\end{tabular}

Fonte: Autor (2015).

A seguir, pode ser visto o painel com os Discursos do Sujeito Coletivo (DSC) referentes a cada um dos 10 significados emersos da coletividade estudada. É o momento do "eu coletivo", constituído pelas Enfermeiras da Atenção Primária à Saúde do Município, representar o "que a Dengue significa para ele".

\section{DSC da Ideia Central A: \\ Desconforto enorme}

Pra mim, foi um desconforto enorme! Dores demais, a única coisa que a gente quer é ficar de cama. Eu acho que é um período curto, mas é muito ruim. Eu tive Dengue, foi bem leve, mas foi horrível! Todo mundo comenta que não é nada bom, que é pior do que você ter um resfriado. Não é coisa de outro mundo porque do mesmo jeito que veio foi embora; foi rápido, não foi complicado nem nada. Mas você se sente mal o tempo todo, se sente enfraquecido, não consegue fazer nem desenvolver nada. Você levanta, suas pernas ficam bambas, dor no corpo, dor no olho. Depois fiquei toda coçando; tive enjoo, vômito, a boca amarga. Uma coisa muito incômoda, muito chata mesmo! As pessoas relatam muita dor de cabeça, eu tive pouco episódio... Eu acho que dificultou vir trabalhar; ficar tomando remédio pra dor e não 
passar. Foi um desconforto enorme que eu não desejo nem pro pior inimigo meu. A partir do momento que você adquire a Dengue, é pensar em ficar de cama e o mais quietinho possível, porque é desconfortável demais. Eu falo que eu não queria Dengue, imagina as crianças... Sofre muito, eu sofri muito. Muito desconfortável! Mas o meu medo maior foi pensar na Dengue hemorrágica; e esse medo eu tive por causa do risco de levar ao óbito. Esse foi o desconforto também, tanto o físico como o mental da preocupação. Foi isso que eu senti.

\section{DSC da Ideia Central B: \\ Problema de saúde pública}

Eu acho que a Dengue é um problema de saúde pública; uma doença que requer atenção especial. O maior problema é o meio ambiente, é a falta de estrutura, é sanitário. A gente está voltando à estaca zero; por mais que a gente está atualizada com os resíduos, com a coleta de lixo, ainda ficaram coisas. Pensar, como que um mosquito, por causa de água, faz esse estrago todo? Então, é uma doença de saúde pública por causa da falta de saneamento básico; por conta da falta de cuidado das pessoas, que não cuidam do seu próprio quintal; que não deixam os agentes de endemia entrar nas casas; uma falta de cuidado que causa transtorno na vida de muita gente. Se alguém tiver Dengue, não pode deixar passar batido, tem que procurar assistência médica e fazer a parte da família. Não é só a pessoa que pega Dengue que tem que se preocupar; todos ao redor, cada um correr atrás. Porque o mosquito vai pra todo lado; às vezes, você vai viajar e traz para a cidade. Ou seja, todo mundo é responsável pela Dengue; se não existir participação popular, da comunidade, a gente não vai conseguir o controle. É um problema que tem que ser olhado! Trata-se de uma questão de saúde pública que envolve os profissionais e a comunidade.

DSC da Ideia Central C:

Descuido das pessoas

A Dengue significa pra mim um descuido das pessoas; uma doença causada pela falta de cuidado com resíduos, com restos de alimentos; uma falta de cuidado da 
população com a saúde. Pela forma que ela é transmitida: água parada vai ter a larva e a produção do mosquito... Eu estava conversando com uma Agente de Controle de Endemias e ela falou que o serviço dela é catar lixo do quintal das pessoas; você dá as orientações, se passar daqui 15 dias está lá o lixo de novo... É uma doença que está sendo contaminada por descuido da população; uma falta de cuidado, porque se a gente trabalhasse melhor a higiene, os rejeitos de lixo, poderia evitar. Hoje em dia, a gente produz muito lixo e não cuida, não dá o destino adequado. Então, eu acho que é descuido das pessoas, resumindo numa frase.

\section{DSC da Ideia Central D: \\ Consequência da falta de educação}

Eu falo que a Dengue é um produto da falta de educação do indivíduo. A gente é muito mal educada nesse sentido, a gente não tem cuidado! Vai jogar as coisas, não tem o cuidado de abrir o lixo pra pôr dentro, joga fora... Esses terrenos abandonados... Do lado da minha casa, eu já fiz inúmeras denúncias pra prefeitura, a prefeitura notifica o dono do terreno, ele vai lá, da uma limpadinha... É falta de educação do ser humano e falta do destino adequado do lixo. Tudo consequência do nosso desenvolvimento precário; consequência da má educação, dos maus hábitos, do não treinamento, ou da falta de consciência. Eu diria que a Dengue é uma consequência da má educação da população.

\section{DSC da Ideia Central E:}

Doença viral

Dengue é uma doença viral, febril, que apresenta dor de cabeça, mal-estar, dor nas articulações, como os sintomas da gripe. A gente como Enfermeiro, como trabalhador da área de saúde, tem a nossa visão técnica. Por isso, do meu ponto de vista, ela é uma doença viral, febril, que não tem medicação específica, a gente trata somente os sintomas e observa sinais de alerta. A partir do momento que você diagnostica bem rápido e toma os devidos cuidados, não é um de bicho de sete cabeças não! Mas tem que tomar medicamento, Dipirona... Dependendo do tipo de Dengue, tem solução, vai curar! Então, eu ia falar que é uma doença viral. 
DSC da Ideia Central F:

Preocupação e medo

Preocupação, medo! Dengue é uma preocupação porque é uma doença que pode matar se não for bem tratada, então a gente tem que ficar em cima do paciente, monitorar, dar informação. É um caso em que todos estão preocupados, entre aspas: preocupado com a casa do outro e esquece que dentro da sua casa também tem esse problema. A população não adere, não aceita, mesmo ficando doente! Acredito que naquela época devem ter tomado algum cuidado maior, resolvido tirar as coisas da horta, os pneus, mas agora já apagou da memória; é o perfil da população. Por mais que a gente informa o paciente, informa a população, ainda tem descaso. Mas é um motivo de preocupação porque nós da saúde, que temos consciência, às vezes não fazemos tudo certo. Nós pelo menos estamos vendo, e quem não vê? Sofreu a doença e não vai fazer nada! Se não se conscientizar, não vamos conseguir mudar. Eles querem cobrar do governo, querem cobrar da prefeitura, mas a gente tem que fazer nossa parte. Talvez, mediante este susto que a população passou agora, tenha mais conscientização. Eu assisti de perto e é muito triste; as pessoas dessa vez ficaram muito ruins. E não acabou, ainda aparece caso, não tem fim. Se esse ano foi desse jeito, imagina o que pode ser ano que vem. Muita preocupação!

\section{DSC da Ideia Central G:}

\section{Doença grave}

Eu acho que a Dengue é grave. Apesar do tempo curto do seu processo, de 7 a 20 dias, esse ano a gente teve casos muito graves aqui no bairro. No ano passado, parecia uma gripinha fraquinha, no máximo em 7 dias tinha acabado, agora dessa vez está durando 15, 20 dias... Então, eu acho que está piorando cada vez mais. $A$ gente tem que se preocupar mesmo, não ficar distante, tomar os cuidados para que ela não aconteça; se policiar com coisas simples dentro da nossa casa: evitar deixar água parada nas plantas, na geladeira, no quintal, nos descartáveis que ficam entulhados. Ela significa pra mim uma doença grave, que eu não gostaria de ter, nem que alguém da minha família tivesse. 
DSC da Ideia Central $\mathrm{H}$ :

Doença causada pela picada do mosquito

A Dengue é uma doença causada pela picada do mosquito Aedes aegypti. Uma doença relacionada ao acúmulo de lixos, de água nos pneus, em garrafas; que precisa ser notificada, tratada, cuidada e que pode levar à morte. Os sintomas mais comuns são: dor no fundo dos olhos, febre alta, em torno de $39,5^{\circ}$, às vezes formigamento no corpo, tudo vermelhinho; a partir do sexto, sétimo dia, o nível de plaquetas começa a baixar, abaixo de 150 mil. É uma doença causada pela picada do mosquito; pra mim a Dengue é isso.

\section{DSC da Ideia Central I:}

Epidemia

A Dengue se tornou um caso de epidemia onde temos que enfrentar cada ano um tipo de vírus diferente. Nós enfrentamos uma guerra com a Dengue aqui nesses últimos meses; já se tornou caso sério dentro da saúde pública. Eu acho que a Dengue é isso para mim hoje: uma epidemia!

\section{DSC da Ideia Central J: Outros significados}

Eu diria que a Dengue é uma doença de país pobre, que infelizmente a gente está vivenciando nos dias atuais. Ela também significa mais uma doença pra gente cuidar! Quando chega um paciente, eu falo: "Ai meu Deus, mais um pra nós cuidarmos!" Porque a gente cuida do paciente; fica atento, fica lembrando daquela pessoa. Mudou do ano passado pra cá, essa atenção... Antes era um caso ou outro que você nem ficava sabendo; mas a partir do momento que o paciente veio, a gente sentiu que precisava cuidar, foi isso. E mais, pra mim a Dengue é uma guerra! Porque cada época é algo diferente; sintomatologia diferente, de paciente pra paciente, de ano pra ano. Uma guerra que nós Enfermeiros e todos da área de saúde temos que enfrentar. Não só no dia-a-dia, mas estudar, porque que o ano que vem vai ser outro tipo; a gente fica realmente preocupada com essa epidemia. 
Dessa forma, do significado de Dengue emergiram as seguintes ideias centrais: "Desconforto enorme"; "Problema de saúde pública"; "Descuido das pessoas"; "Consequência da falta de educação"; "Doença viral"; "Preocupação e medo"; "Doença grave"; "Doença causada pela picada do mosquito"; "Epidemia"; “Outros significados”, conforme ilustração síntese da Figura 3.

Figura 3 - Significados da Dengue, segundo as Enfermeiras da Atenção Primária à Saúde de Alfenas, MG.

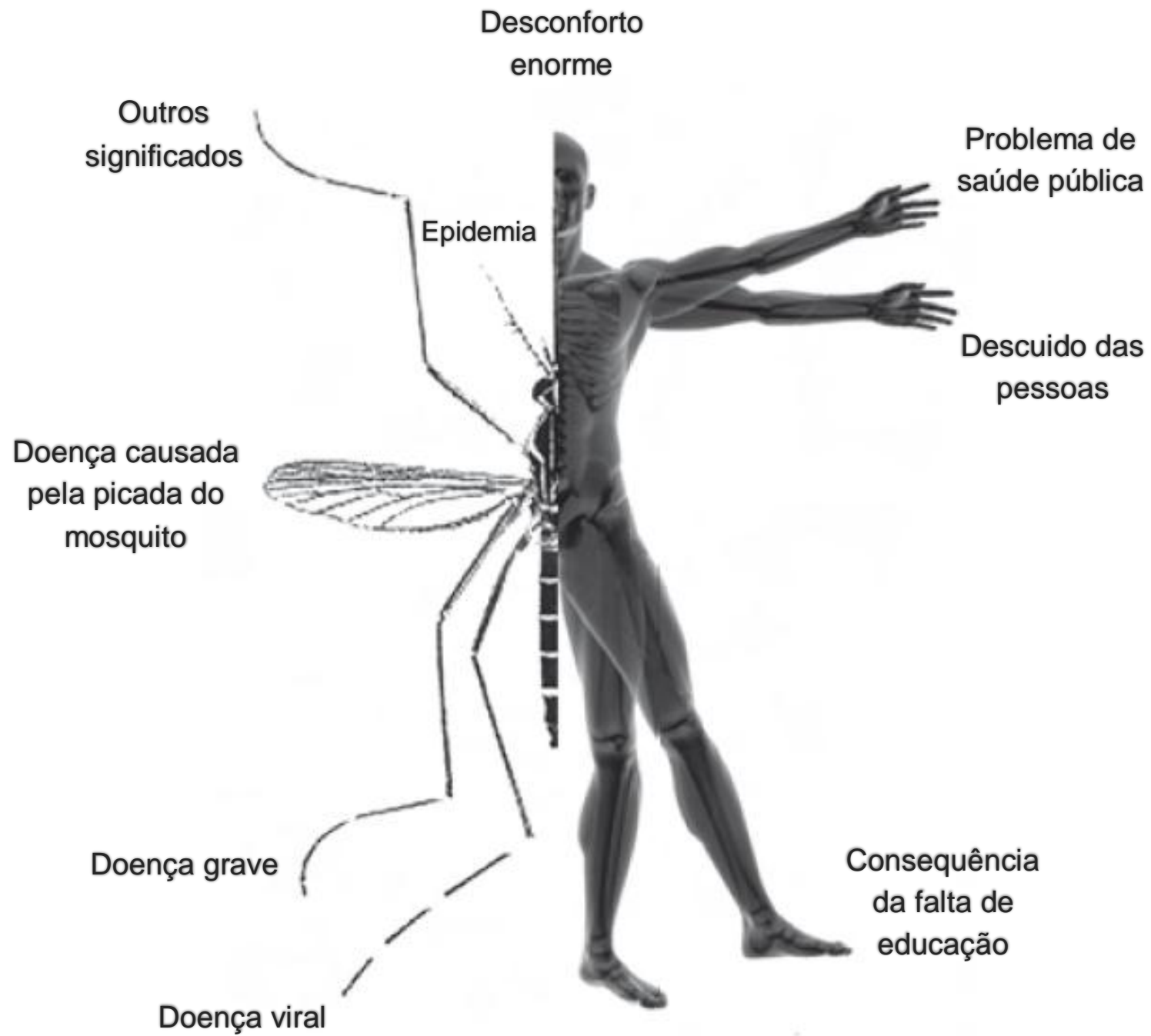

\section{Preocupação e}

medo

Fonte: Who (2009, p. 22). (Houve alteração na ilustração com acréscimo de texto, para fins de representação como imagem-síntese). 


\subsubsection{Tema: Dificultadores para o Controle da Dengue}

É exposto no Quadro 3 o agrupamento das Ideias Centrais iguais, semelhantes e complementares sobre os Dificultadores para o controle da Dengue, conforme a perspectiva da população de estudo.

Quadro 3 - Agrupamento das Ideias Centrais iguais, semelhantes e complementares do tema: "Dificultadores do controle da Dengue".

\begin{tabular}{|c|c|}
\hline $\begin{array}{l}\text { Ideias Centrais iguais, semelhantes e } \\
\text { complementares }\end{array}$ & IC agrupadas \\
\hline $\begin{array}{l}\text { A população } \\
\text { Falta de entendimento da população } \\
\text { Falta de conscientização da população } \\
\text { Dificuldade de conscientização da pessoa } \\
\text { Falta de conscientização das pessoas } \\
\text { Falta da conscientização da população } \\
\text { Falta de conscientização da população } \\
\text { Falta de conscientização das pessoas } \\
\text { As pessoas } \\
\text { Falta de educação da população } \\
\text { O vizinho } \\
\text { Falta de conscientização da população sobre a } \\
\text { gravidade da Dengue }\end{array}$ & $\begin{array}{l}\text { A - Falta de conscientização } \\
\text { da população }\end{array}$ \\
\hline $\begin{array}{l}\text { Resistência das pessoas } \\
\text { Falta de responsabilidade }\end{array}$ & $\begin{array}{l}\text { B - Resistência e falta de } \\
\text { responsabilidade das } \\
\text { pessoas }\end{array}$ \\
\hline $\begin{array}{l}\text { Muitas questões } \\
\text { Alta proliferação do mosquito } \\
\text { Grande quantidade de foco } \\
\text { Boatos } \\
\text { Falta de informação sobre a doença em sí } \\
\text { Não saber a causa } \\
\text { Capacitação dos ACE } \\
\text { Falta de mais cobrança dos ACS }\end{array}$ & C - Muitas questões \\
\hline
\end{tabular}

Fonte: Autor (2015).

Os agrupamentos de Ideias Centrais são apresentados no Quadro 4, juntamente com a identificação cronológica e a quantificação dos participantes que discursaram sobre as Dificuldades. 
Quadro 4 - Dificultadores do controle da Dengue, conforme Ideias Centrais, participantes do estudo e frequência.

\begin{tabular}{|l|c|c|}
\hline \multicolumn{1}{|c|}{ Dificultadores } & Participantes & Frequência \\
\hline A - Falta de conscientização da população & $\begin{array}{c}2,3,4,5,6,7,9, \\
11,14,15 \text { e } 16\end{array}$ & 11 \\
\hline $\begin{array}{l}\text { B - Resistência e falta de responsabilidade } \\
\text { das pessoas }\end{array}$ & 8 e 13 & 2 \\
\hline C - Muitas questões & $\begin{array}{c}1,9,10,12,15 \text { e } \\
17\end{array}$ & 6 \\
\hline \multicolumn{1}{|c|}{ Total } & & 19 \\
\hline
\end{tabular}

Fonte: Autor (2015).

A seguir, é apresentado o painel dos DSCs, referentes aos três agrupamentos representados pelo "eu coletivo" dos profissionais de saúde pesquisados, sobre "o que dificulta o controle da Dengue".

\section{DSC da Ideia Central A:}

\section{Falta de conscientização da população}

O que dificulta é a falta de conscientização da população; o maior problema é a população que não colabora! Falta entendimento, educação, aderência, comprometimento das pessoas. Quando você vai orientar: "ah, eu já sei disso"! Se já sabe de tudo que a gente orienta, como que está tendo Dengue lá? Muitas pessoas se preocupam, mas outras não ligam, mantêm as casas mal arrumadas, não cuidam, o que prejudica muito a população. A gente ainda vê muita falta de cuidado com o domicílio: entulho dentro de casa, os vasos de plantas, as calhas, a caixa d'água, essas coisas simplesinhas; ficam preocupados com a piscina do vizinho e esquecem que dentro de casa também tem esse risco. Existem terrenos baldios, sujos, com coisas jogadas; têm aqueles abandonados que ficam por conta da prefeitura; os que são murados, fechados, que não tem como a gente fazer muita coisa. Em alguns bairros, têm muitas oficinas de lavar carros a céu aberto, onde não tiram aquela água que cai das mangueiras. A pessoa não se conscientiza que ela tem responsabilidade sobre aquele local; cada proprietário tem que assumir sua responsabilidade. Eu cuido da minha casa, mas meu vizinho não cuida. Os pacientes perguntam: "Por que eu faço a limpeza da minha casa, eu cuido da minha casa, e a minha vizinha não cuida da casa dela? Ela não deixa ninguém entrar na 
casa, nem o pessoal da Dengue pra fazer o controle. Então, eu pego Dengue por causa do vizinho." Essa também é a preocupação do pessoal da vigilância, que faz as visitas nas nossas microáreas: o vizinho! As pessoas têm que se conscientizar e cuidar do seu quintal não só no período da Dengue; tem que pensar no pessoal que vive do lado; se ver um lugar que é foco falar pra vigilância, deixar os agentes de endemia entrar. O trabalho dos agentes de endemias de casa em casa falando é um trabalho difícil, muitos nem abrem a porta! Enquanto não tiver uma pena não vai acabar. E não é falta de conhecimento não, eles têm noção, porque a mídia tá aí, a informação está aumentando, têm os profissionais, nós estamos aqui, fazendo panfletagem, trabalhos com eles de conscientização porta a porta, com os agentes em cada microárea, mas o retorno é pequeno. A gente orienta, mas a população não colabora; esse surto é responsabilidade da população que acha que isso nunca vai acontecer com ela. Talvez a vacina vá até dificultar porque as pessoas vão achar que estão imunizados e só vai piorar. Esse ano se trabalhou bastante a divulgação; por outro lado, ainda falta trabalhar a conscientização da população com relação à gravidade da Dengue. Eu acho que os meios de comunicação devem informá-los sobre a seriedade da doença; a população toda não sabe da gravidade, do mal que podem estar trazendo. Até o profissional de saúde às vezes fica descrente: "ah, vou orientar as mesmas coisas". Mas a gente tem que trabalhar a conscientização, a educação e a prevenção de danos. A partir do momento que um indivíduo adoece, ele causa uma série de danos não só pra ele, mas pra todo o meio em que vive. E é um trabalho de formiguinha, tem que persistir, continuar o resto da vida; até as pessoas conseguirem entender que é dessa forma que a gente vai erradicar. A culpa e a responsabilidade são nossas; eu entro na população, todos nós entramos, é um descaso nosso mesmo. Essa falta de conscientização da população em geral é um predominante que dificulta muito o controle da Dengue. Eu acho isso.

\section{DSC da Ideia Central B:}

\section{Resistência e falta de responsabilidade das pessoas}

Eu acredito que o que dificulta o controle da Dengue é a resistência das pessoas em cuidar do seu pedaço, da sua casa. Acho que não é falta de informação, é falta de responsabilidade; e a responsabilidade como ser humano, como cidadão, de pensar 
no próximo, de ouvir as orientações que são dadas através da televisão, dos agentes de endemias que fazem a visita. Só que eles acham que não vão ter; que o vizinho vai ter e ele não. Se cada ser humano soubesse a importância de fazer a prevenção da Dengue, se cada pessoa cuidasse do seu local, acho que ajudaria muito.

DSC da Ideia Central C:

Muitas questões

Acho que aí vai entrar em muitas questões: desde o clima, a região geográfica, até o comprometimento das pessoas. O principal é conseguir o comprometimento de todo mundo, porque isso envolve tanto o profissional - que tem que ter recursos humanos e infraestrutura pra trabalhar - quanto o outro lado, que é a comunidade: trabalhar a cabecinha da comunidade; às vezes, uma casa faz certinho e três casas já não aderem àquela orientação que recebeu; o mais difícil é isso. O que também dificulta o controle da Dengue é a alta proliferação do mosquitinho; a dificuldade que é cuidar dessa questão, de você localizar, porque tem muito foco. Todo mundo tem reservatórios de água em casa, por mais que cuide. Acho que tem que acabar com o mosquito mesmo pra acabar com a doença, não tem outro jeito; o bichinho é safado! Então, o que dificulta o controle da doença é a questão do mosquito se proliferar facilmente em água e ter uma grande quantidade de foco. Outra dificuldade é você não saber o que está causando o maior número de casos naquele lugar; eu não sei o porquê. A epidemiologia não me apresentou nada; se fizeram estudo, se já chegaram a alguma conclusão. O que dificulta o controle é a falta de levantamento do que está causando: O que dificultou o controle daqui? Eles encontraram mais o que nas casas? Onde que está o maior foco? Por quê? Eu não tive. Assim, o que dificulta o controle é você não saber a causa; você tem que saber a causa pra poder combater. Outro aspecto é a falta de informação da população relacionada à doença em si. A pessoa pensa que é o mosquitinho que pica e que você vai ter uma dorzinha, que é uma coisa passageira, não tem ideia do que realmente é a Dengue, da complexidade da doença. Eu acho que ficou muito em cima dos sintomas; a informação em relação à prevenção também está mais que clara. Agora temos que esmiuçar e divulgar um pouquinho mais a doença, as consequências que ela pode trazer. Eu diria ainda que o que dificulta é a capacitação dos agentes. Não é o 
número, porque a gente tem um grande número que daria conta de manter no mínimo controlado o caso de Dengue, mas o treinamento. No caso aqui de Alfenas, os agentes de endemias já pensam assim, vou entrar na prefeitura porque funcionário público não trabalha; aí o dia que tá com sol quente eles não saem, dia que chove eles não saem, já não trabalham. E falta também, dos PSFs, mais cobrança em cima dos agentes de saúde; porque a visita deles não é um mero: "você tá precisando de alguma coisa? Um médico vai atender tal dia...". Penso que mais uma educação permanente, continuada. Também saiu um boato que tinha um ladrão vestido de agente de endemia entrando nas casas; acho que isso cria medo e resistência na população, daí a pessoa não deixa os agentes de saúde entrar. Enfim, envolve tudo isso; são muitas questões.

Assim, sobre os dificultadores para o controle da Dengue emergiram as seguintes ideias centrais: "Falta de conscientização da população"; "Resistência e falta de responsabilidade das pessoas"; e "Muitas questões", como apresentado na ilustração síntese da Figura 4.

Figura 4 - Dificultadores para o controle da Dengue, segundo as Enfermeiras da Atenção Primária à Saúde de Alfenas, MG.

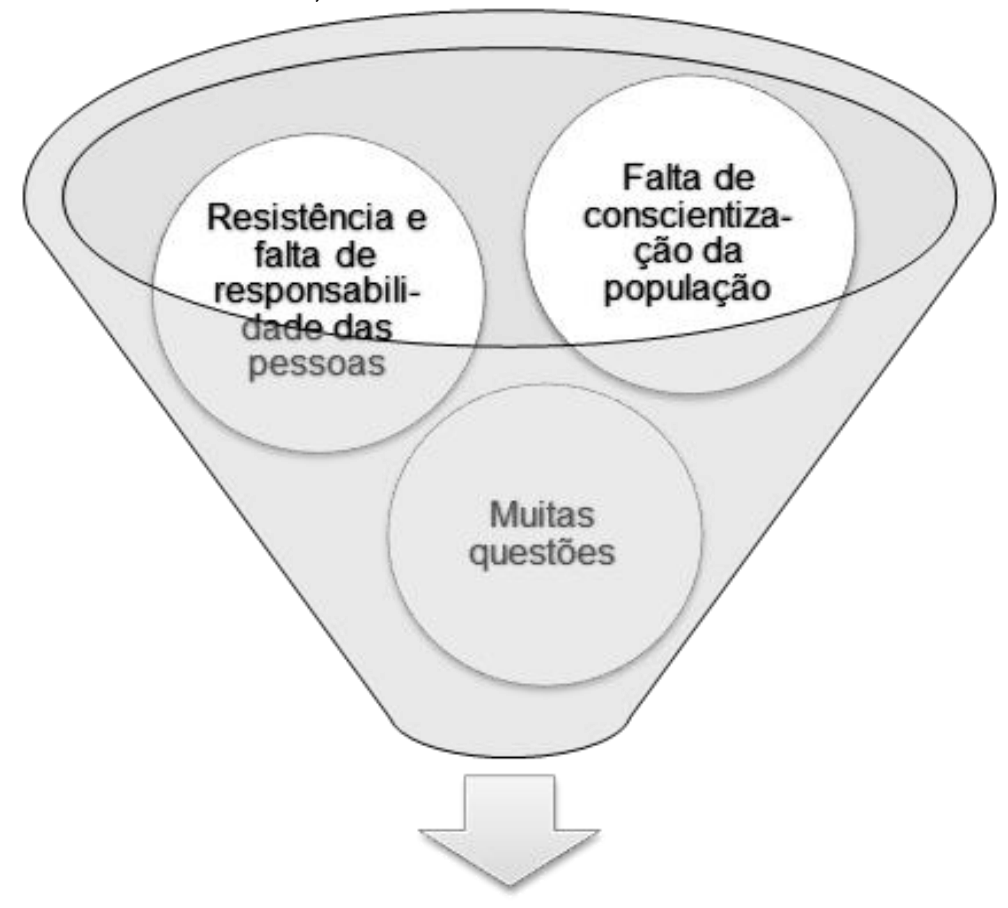

Controle dificil

Fonte: Autor (2015). 


\subsubsection{Tema: Facilitadores para o Controle da Dengue}

Já no Quadro 5, pode-se acompanhar o agrupamento das Ideias Centrais iguais, semelhantes e complementares, que as Enfermeiras da Atenção Primária à Saúde de Alfenas-MG apontaram como Facilitadores do Controle da Dengue.

Quadro 5 - Agrupamento das Ideias Centrais iguais, semelhantes e complementares do tema: "Facilitadores do Controle da Dengue".

\begin{tabular}{|c|c|}
\hline $\begin{array}{c}\text { Ideias Centrais iguais, semelhantes e } \\
\text { complementares }\end{array}$ & IC agrupadas \\
\hline Trabalho de orientação & \\
\hline $\begin{array}{l}\text { Orientação nas escolas } \\
\text { Trabalho de conscientização } \\
\text { Conscientização das pessoas }\end{array}$ & $\begin{array}{l}\text { A - Trabalho de orientação } \\
\text { e de conscientização }\end{array}$ \\
\hline $\begin{array}{l}\text { Educação } \\
\text { Educação da população }\end{array}$ & $\begin{array}{l}\text { B - Educação da } \\
\text { população }\end{array}$ \\
\hline $\begin{array}{l}\text { Conscientização da população } \\
\text { Consciência de cada um }\end{array}$ & $\begin{array}{l}\text { C - Consciência das } \\
\text { pessoas }\end{array}$ \\
\hline $\begin{array}{l}\text { Melhorar o saneamento básico } \\
\text { Combater o mosquito }\end{array}$ & D - Saneamento básico \\
\hline $\begin{array}{l}\text { Parceria dos agentes endêmicos } \\
\text { Parceria com o pessoal do agente de endemia } \\
\text { União de forças }\end{array}$ & E - Parcerias \\
\hline Não há facilitadores & F - Não há facilitadores \\
\hline $\begin{array}{l}\text { Divulgações } \\
\text { Quantidade de informação }\end{array}$ & G - Informações \\
\hline $\begin{array}{l}\text { Diversos facilitadores } \\
\text { Cobrança } \\
\text { Capacitar e remunerar melhor os ACE } \\
\text { A população fazer a sua parte }\end{array}$ & H - Diversos facilitadores \\
\hline
\end{tabular}

Fonte: Autor (2015).

Os Facilitadores para o Controle da Dengue, segundo o agrupamento das Ideias Centrais, são apresentados juntamente com a identificação cronológica e a quantificação dos participantes, conforme Quadro 6. 
Quadro 6 - Facilitadores do Controle da Dengue, conforme Ideias Centrais, participantes do estudo e frequência.

\begin{tabular}{|l|c|c|}
\hline \multicolumn{1}{|c|}{ Facilitadores } & Participantes & Frequência \\
\hline $\begin{array}{l}\text { A - Trabalho de orientação e de } \\
\text { conscientização }\end{array}$ & $3,6,7$ e 8 & 4 \\
\hline B - Educação da população & 5 e 11 & 2 \\
\hline C - Consciência das pessoas & 13 e 14 & 2 \\
\hline D - Saneamento básico & 9 & 1 \\
\hline E - Parcerias & 3,4 e 12 & 3 \\
\hline F - Não há facilitadores & 16 & 1 \\
\hline G - Informações & 10 e 15 & 2 \\
\hline H - Diversos facilitadores & $1,2,3$ e 17 & 4 \\
\hline \multicolumn{2}{|c|}{ Total } & 19 \\
\hline
\end{tabular}

Fonte: Autor (2015).

A seguir, encontram-se os Discursos do Sujeito Coletivo (DSC) referentes aos 8 Facilitadores que as Enfermeiras da Atenção Primária à Saúde de Alfenas-MG apontaram em resposta à pergunta: "[...] o que facilita o controle da Dengue? [...]".

\section{DSC da Ideia Central A:}

\section{Trabalho de orientação e de conscientização}

O que facilita é o trabalho de orientação e conscientização que a gente está fazendo. Eu acho que um dos trabalhos que a gente teve bastante resultado foi com a orientação nas escolas. As próprias crianças pequenininhas levarem pra casa como tarefa de orientação. Chegar e falar assim: "óh mãe, esse vasinho está errado". Desde pequenininho; isso pra mim é uma facilidade. Também a gente conscientizar as pessoas com propagandas, panfletos, nas unidades de saúde. A partir do momento que começa a passar na televisão, entregar panfletos, as pessoas veem quais são os sintomas, já correm atrás, se informam melhor, ficam preocupadas; isso facilita um controle melhor. Uma coisa que temos hoje em dia e que pode facilitar muito, se a gente souber usar, são a mídia e as redes sociais; a maioria das pessoas tem acesso. Foi até uma opção que o pessoal usou bastante: 0 Facebook pra divulgar mensagem de campanha contra a Dengue. Não deixando de 
lado o "tête-à-tête", o "casa-a-casa", as palestras em si; mas, usar desses meios (rádio, televisão, celular com Facebook) pra divulgar, pra trabalhar essa conscientização. Em suma, o que facilita o controle da Dengue é o pessoal não desistir de trabalhar nas orientações.

\section{DSC da Ideia Central B:}

\section{Educação da população}

Acho que está tudo baseado na educação da pessoa; o que facilitaria seria a educação da população. A população ter a noção da gravidade da doença, e trabalhar como agentes disseminadores do conhecimento. Infelizmente, as pessoas chegam a essa conclusão a partir do momento que passam pela dor. Enquanto você está falando, ninguém quer conscientizar, mas, a partir do momento que afeta... Quer dizer, nós somos muito mal educados. Não deixar água acumulada, lixo acumulado, educação ambiental. Você passa perto de um rio, o rio está cheio, entulhado de lixo, transbordando. Cada vez mais, nós estamos produzindo mais resíduos, estamos produzindo mais lixos, estamos ficando mais desorganizados, mais mal educados. Só que a Dengue não vai servir pra barrar essa falta de educação. Se todo mundo tivesse educação e conhecimento como deveria, eu acho que estaria tudo certo. O povo precisa ser mais educado. Isso tudo está relacionado com educação, toda saúde da pessoa está relacionada com educação da população; eu acho isso.

\section{DSC da Ideia Central C:}

\section{Consciência das pessoas}

É a consciência de cada um, a conscientização da população, o que facilita. Eu acho que propaganda existe, está na mídia, cartazes pra todo lado, o agente comunitário trabalha nessa educação sanitária, tem o pessoal da vigilância, os agentes da Dengue. Acho que a divulgação até está sendo muito repetitiva; muitas casas eu passei orientando e o problema continuava o mesmo. Agora, eu também acho que usaram os meios de informação pra população com a Dengue já instalada, a população já sofrendo com a doença, deveria ter feito isso a nível preventivo. Usar 
os meios de comunicação e informar sobre a Dengue, os sintomas, antes. Ninguém sabe a gravidade da Dengue, só nós da saúde; e nesse ano posso garantir pra você que foi bem pior! Só jogar a responsabilidade é muito mais fácil, mas as pessoas esquecem que em primeiro lugar a responsabilidade é nossa, não é do prefeito, não é do seu vizinho, a responsabilidade é nossa. Vou dizer a verdade pra você, a população não se importou com a Dengue; e isso é grave! A população tem que se conscientizar, tem que querer fazer a parte preventiva. Se eu chegar numa casa que tem um monte de entulhos e conscientizar esse indivíduo sobre a doença, sobre os cuidados com a Dengue, ele fala que isso não existe; amanhã o vizinho do lado aparece aqui com os sintomas da Dengue. Uma questão cultural talvez, não é? Conhecimento tem, não tem é responsabilidade, comprometimento, como pessoa, como cidadão, que têm direitos e deveres. Então, o que está faltando é conscientização; o que facilita pra mim é a consciência das pessoas.

\section{DSC da Ideia Central D:}

\section{Saneamento básico}

O que vai facilitar é melhorar a questão de saneamento básico, porque é uma doença primária, uma coisa muito básica; tem que acabar, não pode continuar. Já está visto que a gente tem é que combater o mosquito, tem que combater a proliferação dele; fazendo aquelas velhas condutas: não deixar água parada, olhar as plantas, o fumacê; e continuar investindo em novas experiências como esses predadores, a vacina. Eu acho que o problema maior é o saneamento; o caminho é esse mesmo.

\section{DSC da Ideia Central E:}

\section{Parcerias}

As parcerias, a união de forças, somar todo mundo; eu acho que isso facilita. Esse ano a gente está tendo um facilitador muito grande, que é a parceria com os agentes de endemia. Eles estão no PSF, estão passando nas áreas; todo caso que nós notificamos eles já vêm na casa fazer a busca, pra ver ao redor ali, pra jogar o Fumacê; isso é um ponto muito importante. A população ficou alerta, começou uma 
preocupação maior; isso foi muito bom. Onde tem dificuldade de acesso eu pedi para o agente de saúde estar junto com o agente da endemia; porque a gente tem essa dificuldade, eles não estão abrindo, infelizmente, para os agentes de endemia. Por ser mais instruída, a população aqui não deixa os agentes entrarem nas suas casas, não recebe nem o agente comunitário, tem essa resistência. Mas a nossa equipe está orientada; a gente encaminha para a Vigilância tomar providência. Mas eu acho que o facilitador mesmo é essa parceria que a gente tem com os agentes de endemia; eles estão sempre atualizando a gente. Quando une forças, o resultado é mais rápido, mais eficaz; acho que é isso que está ajudando.

DSC da Ideia Central F:

Não há facilitadores

Eu nem diria que facilita. A gente teve um bom resultado dessa vez porque eu consegui ver os meus pacientes que estavam com Dengue de perto. Porque o hospital bloqueou lá, não atendeu e acabou que a gente assistiu mais aqui. Das outras vezes, como eram poucos casos, nós não tivemos essa visão. Agora dessa vez foi assustador! Eu achei que a Dengue nos ajudou a enxergarmos melhor os nossos pacientes. Então, eu não vejo o que facilitou.

DSC da Ideia Central G:

Informações

O que facilita é essa quantidade de informação. Hoje em dia, qualquer lugar que você for, num mercado, você vai achar um cartazinho falando. Pelo menos a gente pregou cartaz em tudo quanto que foi estabelecimento. Então, as informações, essas divulgações estão muito presentes, na internet, na televisão, panfletagem, o próprio agente de endemia, o PSF com os agentes de saúde orientando nas casas. Então, pra mim, eu acho que essas informações são o que facilitam. 
DSC da Ideia Central H:

Diversos facilitadores

A conscientização ajuda; o trabalho de educação em saúde facilita; propaganda do Governo; o trabalho da Vigilância quando descobre que tem um foco; o Fumacê ajuda no controle também. Quando a gente notifica, eles ficam mais atentos; o trabalho dos nossos gestores de divulgar, de intervir; a educação. Também acho que a população fazer sua parte facilitaria; porque é dentro de casa que acham maioria dos focos. A gente faz a nossa parte profissional, as pessoas têm que se tornarem mais responsáveis também. Acho que tem que voltar pra parte de cobrança mesmo, eu não falo de dinheiro, nem se for serviço social, aí a população vai começar a prestar mais atenção. Eu acho ainda que o que facilita é a gente capacitar e remunerar melhor os agentes; se ele é bem pago, vai querer trabalhar pra ver o resultado. Se eles tivessem um incentivo financeiro maior ajudaria, iriam trabalhar em cima de produção; isso ajudaria a diminuir os casos de Dengue também.

Portanto, em relação aos facilitadores do controle da Dengue, emergiram as seguintes ideias centrais: "Trabalho de orientação e conscientização"; "Educação da população"; "Consciência das pessoas"; "Saneamento básico"; "Parcerias"; "Não há facilitadores"; "Informações" e "Diversos facilitadores", como podem ser visualizados na ilustração síntese da Figura 5. 
Figura 5 - Facilitadores para o controle da Dengue, segundo as Enfermeiras da Atenção Primária à Saúde de Alfenas, MG.

\section{Parcerias}

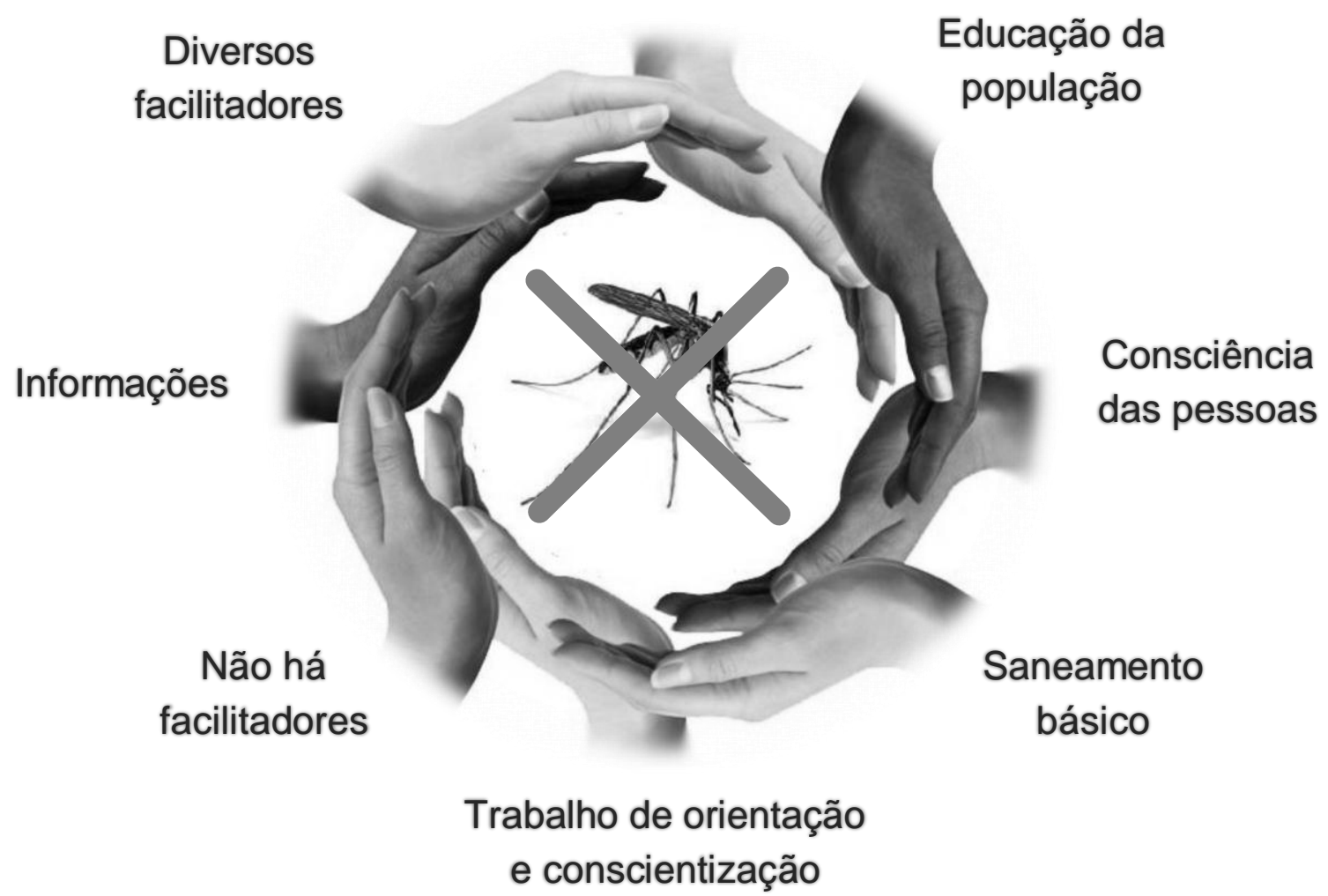

Fonte: Freire (2014). (Houve alteração de cor, acréscimo do "X" e substituição de texto na ilustração, para fins de representação como imagem-síntese). 


\section{DISCUSSÃO}

Este capítulo destina-se à discussão dos achados da pesquisa. Para tanto, foi adotada a sequência de temas apresentada no tópico dos resultados: Significados da Dengue; Dificultadores para o Controle da Dengue; e Facilitadores para o Controle da Dengue.

\subsection{SIGNIFICADOS DA DENGUE}

Após a análise, os significados da Dengue para os Enfermeiros da APS de Alfenas foram agrupados em quatro eixos para discussão, conforme sentido das ideias centrais:

1) sentimentos: A - Desconforto enorme; F - Preocupação e medo;

2) conceitos: B - Problema de saúde pública, E - Doença viral, G - Doença grave, $\mathrm{H}$ - Doença causada pela picada do mosquito e I - Epidemia;

3) culpabilidade: C - Descuido das pessoas; e D - Consequência da falta de educação;

4) outros: J - Outros significados.

\subsubsection{Sentimentos}

No primeiro eixo de discussão, os significados da Dengue emersos representaram sentimentos gerados pelo contato pessoal e profissional com a enfermidade. A seguir, são analisados os DSCs "Desconforto enorme" e "Preocupação e medo".

\subsubsection{Desconforto Enorme}

Apesar de a Dengue poder se apresentar nas formas assintomática, oligossintomática ou sintomática, a descrição dos Enfermeiros da APS para o significado "Desconforto enorme" teve relação com alguns sintomas da forma clássica da doença: [...] Dores demais, a única coisa que a gente quer é ficar de cama. [...] foi horrível! [...] você se sente mal o tempo todo, se sente enfraquecido, 
não consegue fazer nem desenvolver nada. Você levanta, suas pernas ficam bambas, dor no corpo, dor no olho. Depois fiquei toda coçando; tive enjoo, vômito, a boca amarga. [...] As pessoas relatam muita dor de cabeça [...].

A literatura apresenta como constituintes possíveis do quadro clínico clássico de Dengue, principalmente: febre alta de início súbito; dores no corpo, artralgia e mialgia, principalmente na região lombar e membros inferiores; cefaleia de localização retro-orbitária; bem como náuseas, disgesia, prostração e anorexia; erupção cutânea no início, com eritema generalizado e fugaz; exantema maculopapular mais evidente na face; e sensação de queimação no tronco, membros e também nas extremidades (XAVIER, et al., 2014; SCHATZMAYR, 2007; BRASIL, 2007b; 2007c).

Há tempos, a Dengue é conhecida com o nome popular de "Febre quebraossos"; o desconforto gerado é claramente descrito no quadro clínico dos acometidos pela enfermidade. Entretanto, o aspecto que chamou atenção foi o incômodo psicológico trazido pela infecção: [...] Mas o meu medo maior foi pensar na Dengue hemorrágica; e esse medo eu tive por causa do risco de levar ao óbito. Esse foi o desconforto também, tanto o físico como o mental da preocupação. Foi isso que eu senti [...]. Esse recorte do DSC faz lembrar os aspectos bio-psico-sociais da doença e remete à importância de uma abordagem integral aos indivíduos com Dengue.

É interessante notar também que, quando o sujeito coletivo alterna no seu discurso os termos "pra mim", "as pessoas relatam" e "foi isso que eu senti", ele sugere que recurso está acessando para construir a representação que foi exteriorizada: se pensamentos dos Universos Consensuais, ou se elucubrações dos Universos Reificados (MOSCOVICI, 2004; LEITE; VELOSO, 2008; OLIVEIRA; WERBA, 2012), já explicados no Capítulo 3. Nesse caso, o significado da Dengue como um desconforto parece ter sido resultado das práticas interativas do dia a dia, ou seja, das teorias do senso comum.

Ao pensar que a representação como um processo mental traduz duas realidades inseparáveis, o lado simbólico e o lado figurativo, nota-se que, quando o indivíduo descreve os sintomas ruins da Dengue como relato de sua experiência, está se apropriando da faceta figurativa das RS.

Por isso a riqueza de detalhes, o discurso carregado de expressões e sentimentos que foram evocados da sua memória. Por ter vivenciado aquela 
situação e interagido com o fenômeno de interesse, obteve uma percepção particular do objeto, registrada pelos próprios sentidos. Vista dessa forma, é possível interpretar sua representação sobre a Dengue como que advinda de seu embasamento pessoal e empírico.

Por outro lado, quando dialeticamente o sujeito coletivo compara os sintomas que "as pessoas relatam" com os da sua queixa pessoal quando experienciou a infecção, ele consegue demonstrar claramente o exercício de compor uma representação sobre a Dengue intercambiada pelo lado simbólico e pelo aspecto figurativo.

Acredita-se que essa característica tenha relação como 0 fato dos dois indivíduos que exteriorizaram as ideias centrais "algo ruim" e "desconforto enorme" fazerem parte dos $23,52 \%$ que foram acometidos por Dengue dentre os entrevistados. O porta-voz dos Enfermeiros com o DSC sobre o "desconforto enorme" se posicionou então como um sujeito coletivo que foi acometido pela doença e que compartilhou informações do senso-comum.

Observa-se, ainda, que tal RS também foi pautada na faceta social e que o significado apresentado pode ter tido pouco a ver com o conhecimento científico compartilhado pelo campo social de sua pertença: a categoria profissional Enfermeiros com atuação da Atenção Primária à Saúde. Com isso, houve aparente predominância de conteúdos do Universo Consensual em detrimento da fundamentação em Universos Reificados.

\subsubsection{Preocupação e Medo}

O significado "Preocupação e medo" foi apresentado como que devido ao risco de morte por Dengue. Segundo o DSC, tais sentimentos foram explicados por um senso de responsabilidade profissional em relação ao manejo clínico do usuário e às atividades informativas sobre a Dengue: [...] preocupação porque é uma doença que pode matar se não for bem tratada, então a gente tem que ficar em cima do paciente, monitorar, dar informação [...].

Para o sujeito coletivo, esses sentimentos fazem parte do cotidiano do profissional de saúde e não das demais pessoas da comunidade. Segundo ele, a população não colabora e age com descaso principalmente nos períodos interepidêmicos: [...] não adere, não aceita, mesmo ficando doente! Acredito que naquela 
época devem ter tomado algum cuidado maior, resolvido tirar as coisas da horta, os pneus, mas agora já apagou da memória [...].

Preocupação e medo também foram identificados no discurso do significado "Desconforto enorme". Entretanto, na primeira ideia central, o incômodo psicológico trazido pela infecção surgiu como uma descrição do desconforto emocional e teve a ver com as experiências dos Enfermeiros enquanto doentes. Já no significado "Preocupação e medo" essas representações surgem como respostas laborais ao acolhimento do usuário enfermo e à possibilidade de evolução dos casos para o óbito.

De fato, a Dengue vem preocupando as autoridades sanitárias em escala global pela sua circulação nos cinco continentes e pelo grande potencial para o desenvolvimento de formas graves e letais de doença (FLAUZINO; SOUZASANTOS; OLIVEIRA, 2009; TAUIL, 2002). No entanto, entende-se como salutar que a preocupação e o medo façam parte do pensamento coletivo dos profissionais e dos gestores de saúde. De certo modo, esses significados podem auxiliar na manutenção de um estado de alerta que não deve se restringir aos períodos epidêmicos.

Em se tratando dos multifacetados aspectos biossociais inerentes ao complexo processo saúde-doença da Dengue (PIMENTA, 2015b), entende-se como razoável que preocupação e medo façam parte do imaginário coletivo dos profissionais entrevistados após uma situação de epidemia.

Com base na experiência das entrevistas, acredita-se que o fato de os Enfermeiros da APS se preocuparem e temerem as complicações e o óbito dos seus pacientes por Dengue possa ter a ver com: 1) a nova organização dos serviços de saúde durante período epidêmico; 2) o seu comprometimento profissional e ético para com os usuários; 3) a sua frágil familiaridade com o protocolo clínico para manejo de usuários com suspeita de Dengue; e 4) a falta de estrutura e de recursos materiais adequados nas Unidades Básicas de Saúde.

Uma mudança do local de atendimento dos casos de Dengue durante a epidemia de 2015 trouxe maior visibilidade para os Enfermeiros da APS sobre a magnitude do problema no Município. Isso porque o maior hospital local ao fazer jus ao acolhimento com classificação de risco segundo o protocolo de Manchester referenciou expressiva parte da demanda por Dengue às Equipes de Saúde da Família. 
Além disso, no Art. 12 do Código de Ética Profissional da Enfermagem consta como parte de suas responsabilidades e deveres: "Assegurar à pessoa, família e coletividade assistência de enfermagem livre de danos decorrentes de imperícia, negligência ou imprudência" (COREN-MG, 2013, p 50; COFEN, 2007). Tal compromisso profissional e ético traz consigo um senso de melhor cuidar que também pode ocasionar a preocupação e o medo presentemente discutidos como significado da Dengue.

Corrobora-se, portanto, com a importância que Tauil (2002) e Cunha e Martínez (2015) dão para os serviços de saúde estarem preparados com profissionais treinados para classificar os casos suspeitos e para decidir as condutas adequadas conforme cada classificação. Deve-se lembrar que tais condutas vão desde o acompanhamento domiciliar até a internação do indivíduo em unidades de terapia intensiva.

Acredita-se que "organizar os serviços de referência dos doentes, reservar leitos hospitalares, manter os insumos necessários e pessoal capacitado", além serem necessidades para uma assistência de qualidade aos acometidos por Dengue nos diferentes níveis de atenção à saúde (TAUIL, 2002. p. 870), constituem medidas com potencial de amenizar a sensação de insegurança, de preocupação e de medo que a Dengue representa para os profissionais entrevistados.

\subsubsection{Conceitos}

Já no segundo eixo de discussão, os Enfermeiros da APS de Alfenas significaram a Dengue como conceitos da doença. Os DSCs "Problema de saúde pública", "Doença viral", "Doença grave", "Doença causada pela picada do mosquito" e "Epidemia" são analisados a seguir.

\subsubsection{Problema de Saúde Pública}

No DSC referente ao significado "Problema de saúde pública", o sujeito coletivo aborda a Dengue como uma doença que requer atenção especial e descreve vários de seus microdeterminantes: [...] Eu acho que a Dengue é um problema de saúde pública; uma doença que requer atenção especial [...]. 
Ele sinaliza também para a importância da procura pelo serviço de saúde em face da infecção, e reforça a necessidade de todos, seja em nível individual ou em coletivo, tornarem-se co-responsáveis pelo enfrentamento da doença: [...] É um problema que tem que ser olhado! Trata-se de uma questão de saúde pública que envolve os profissionais e a comunidade [...].

A permanência da Dengue como um importante problema de saúde na atualidade constituiu a justificativa principal deste trabalho. Epidemias recorrentes nas regiões tropicais da Ásia, da África e das Américas, assim como o impacto do agravo na economia de diversos países continuam sendo descritos na literatura (GALLER; BONALDO; ALVES, 2015; MCARTHUR; SZTEIN; EDELMAN, 2013; BHATT et al., 2013; STAHL et al., 2013; DICK et al., 2012).

Mustafa et al. (2015), Flauzino, Souza-Santos, Oliveira (2009) e Tauil (2002) reforçam a Dengue como um problema de saúde pública re-emergente e argumentam que há risco desta infecção para dois quintos da população mundial cerca de 2,5 a 2,9 bilhões de pessoas.

Segundo o Ministério da Saúde, até a Semana Epidemiológica (SE) de número 36, em 2015, haviam sido notificados 1.438 .497 casos de Dengue no Brasil. Destes, foram confirmados 1.318 casos graves e 17.183 casos com sinais de alarme. Isso equivale a um aumento de $194,68 \%$ e $214,92 \%$, respectivamente, em relação ao mesmo período de 2014. Também foi observado um aumento do número de óbitos de 415 indivíduos em 2014 para 709 pessoas, até 12 de setembro de 2015 (BRASIL, 2015). Esses dados mostram que o controle da Dengue permanece como um desafio para a saúde pública brasileira (PENNA, 2003).

No Estado de Minas Gerais, até o dia 09 de dezembro de 2015, haviam sido confirmados 146.004 casos de Dengue e outros 35.723 tinham sido considerados suspeitos (SES-MG, 2015). Já no Município Sul Mineiro de Alfenas, até o dia 05 de novembro de 2015 foram registrados 2037 casos confirmados da doença (ALFENAS, 2015). Pensando no número de casos dos últimos quinze anos em Alfenas-MG, divididos por quinquênios, é possível notar que de 2011 a 2015 houve um incremento de $2314 \%$ em relação a 2001 a 2005; e de 3655\% comparando com os anos de 2006 a 2010.

Dessa forma, a Dengue significar um problema de saúde pública para os profissionais de saúde é uma representação positiva, uma vez que essa ideia condiz com a realidade epidemiológica do local. Além disso, tal significado possui potencial 
de suscitar atenção e preocupação dos atores sociais pesquisados para com 0 presente objeto de estudo: a Dengue. Entretanto, o interessante seria que a Dengue fosse compreendida, para além de um problema de saúde pública, como uma questão de saúde coletiva.

Pensando em processo de trabalho, a Saúde Pública utiliza como instrumentos a epidemiologia tradicional, o planejamento normativo e a administração taylorista, que se referem a abordagens e a concepções biologistas da saúde. Por outro lado, a Saúde Coletiva procura utilizar a epidemiologia social ou crítica e as ciências sociais para estudar a determinação social, as desigualdades em saúde, o planejamento estratégico/comunicativo e a gestão democrática (SOUZA, 2014).

Assim, uma mudança paradigmática importante em relação à compreensão e ao enfrentamento da Dengue diz respeito à transição das ações isoladas da Vigilância Epidemiológica, da Vigilância Sanitária ou dos programas especiais desarticulados das demais ações - característicos da saúde pública - para o acolhimento de todos os saberes, científicos e populares - sobre o qual se debruça a saúde coletiva. Segundo Souza (2014, p. 18), o mix entre o conhecimento científico e o conhecimento empírico pode contribuir para elevar a "consciência sanitária e a realização de intervenções intersetoriais sobre os determinantes estruturais da saúde".

Não há intenção de discutir os aspectos epistemológicos da dialética entre a saúde pública e a saúde coletiva (CAMPOS, 2000). Entretanto, cabe chamar a atenção para o discurso elaborado sobre a Dengue como problema coletivo: [...] envolve os profissionais e a comunidade [...].

O enfrentamento da Dengue no contexto da Reforma Sanitária Brasileira deve ser coerente com esse movimento. Segundo o DSC discutido, deve [...] existir participação popular [...]. Assim, diante da Dengue como um problema essencialmente coletivo um significado mais abrangente para a doença seria então: um problema de saúde pública e uma questão de saúde coletiva.

\subsubsection{Doença Viral}

O sujeito coletivo que contribuiu com o significado "Doença viral" se posicionou como profissional de saúde para descrever de forma técnica as 
manifestações clínicas da doença: [...] A gente como Enfermeiro, como trabalhador da área de saúde, tem a nossa visão técnica. Por isso, do meu ponto de vista, ela é uma doença viral, febril, que não tem medicação específica. [...] que apresenta dor de cabeça, mal-estar, dor nas articulações, como os sintomas da gripe [...].

A Dengue é uma doença viral e o seu agente etiológico faz parte do gênero Flavivírus, da família Flaviviridae (BHATT et al., 2013; STAHL et al., 2013). Seus sorotipos são biológica e antigenicamente distintos, mas sorologicamente relacionados (CATÃO, 2012; TAUIL, 2001). No entanto, ao representar a Dengue como doença viral, os Enfermeiros não demonstraram em seu discurso elemento algum que sugerisse lembrança sobre a classificação do patógeno, nem dos seus subtipos.

Em relação à confirmação dos vírus circulantes no Brasil em 2015, um documento do Ministério da Saúde mostrou que até a Semana Epidemiológica de número 36, houve 7.381 resultados positivos nos exames de isolamento viral. Esse número configura $40,4 \%$ das 18.281 amostras enviadas para análise. Dentre as proporções dos sorotipos virais identificados, houve destaque para o DENV1 $(93,4 \%)$ e o DENV4 $(5,4 \%)$, seguidos pelo DENV2 $(0,8 \%)$ e DENV3 $(0,5 \%)$ (BRASIL, 2015).

Já sobre a natureza da representação per sí, ao se situar como um depoente técnico que procurou relatar parte do conhecimento científico em detrimento do embasamento empírico, o eu coletivo representou a Dengue por meio de simbolismo. Uma observação que reforça a possível evocação da realidade icônica para a elaboração da representação e da exteriorização do significado é o fato de os Enfermeiros que contribuíam com o DSC "Doença viral" não terem tido Dengue.

No DSC anteriormente discutido sobre "Desconforto enorme", alguns sintomas da forma clássica da doença foram abordados de forma figurativa pelos que relataram sua própria experiência como enfermos. Já na significação da Dengue como "Doença viral", ao processar as RS para tornar familiar o não familiar, os profissionais simbolizaram e fundamentaram seu discurso no seu conhecimento técnico, uma vez que o valor figurativo proporcionado pela vivência das manifestações clínicas estava distante da sua realidade.

Já em relação ao tipo de universo de pensamento de onde os Enfermeiros representaram, parece ter havido um embasamento em ambos os Universos, no Reificados (UR) e nos Consensuais (UC). Isso porque, pensando no conhecimento 
sobre o atendimento ao usuário com suspeita de Dengue como conhecimento teórico-prático, os significados podem ser resultado tanto do conhecimento científico, como dos saberes do senso comum, quanto de ambos.

Outra observação referente ao significado "Doença viral" diz respeito à forma com que o sujeito coletivo encara o manejo clínico e o prognóstico dos usuários: [...] a gente trata somente os sintomas e observa sinais de alerta. [...] A partir do momento que você diagnostica bem rápido e toma os devidos cuidados, não é um de bicho de sete cabeças, não! [...] Dependendo do tipo de Dengue, tem solução, vai curar! [...].

De fato, a Dengue apresenta fisiopatogenia e manifestações clínicas de complexidade razoável e exige um manejo clínico de certa forma simples, barato e eficaz. Essas características não se opõem de modo algum aos significados "Preocupação e medo" e "Problema de saúde pública / saúde coletiva" emersos e discutidos anteriormente. A Dengue representa, sim, um problema de saúde que causa preocupação e medo, no entanto a instituição do manejo clínico correto e em tempo hábil pode evitar boa parte das complicações e dos óbitos pela doença (CUNHA; MARTÍNEZ, 2015; WHO, 2012).

\subsubsection{Doença Grave}

$\mathrm{Na}$ análise do significado "Doença grave", é possível identificar dois pensamentos aparentemente contraditórios, mas que foram interpretados neste trabalho como concepções diferentes e possíveis que o sujeito coletivo possui sobre a gravidade da doença.

Numa das abordagens, a Dengue é vista como uma doença grave que está piorando cada vez mais, apesar do curto período de tempo em que a infecção se manifesta. Nesse sentido, a duração do processo saúde-doença é curta, mas a intensidade gradativa das manifestações clínicas representa a gravidade verbalizada.

Já no segundo ponto de vista, o que parecia uma gripe fraca, com duração máxima de uma semana, com o passar dos anos, tem apresentado sintomas prolongados que chegam a mais de 15 dias. Sob esse aspecto, a intensidade dos sintomas parece não ser a preocupação principal; a característica do alargamento 
temporal em que ocorrem as manifestações clínicas é que constitui numa "piora" gradativa e reflete uma evolução da gravidade da doença.

O Brasil utiliza desde 2014 a nova classificação de Dengue que enfatiza tal agravo como uma doença única, dinâmica e sistêmica. Ou seja, o quadro pode "evoluir para remissão dos sintomas, ou pode agravar-se exigindo constante reavaliação e observação, para que as intervenções sejam oportunas e que os óbitos não ocorram" (BRASIL, 2016, p. 6).

Apesar de não ter havido menção de casos extremos com falência de órgãos, hemorragia, extravasamento capilar, choque e óbito - característicos da Febre Hemorrágica da Dengue (FHD) - o sujeito coletivo observou uma mudança no padrão de gravidade da doença na sua área adstrita: [...] esse ano a gente teve casos muito graves aqui no bairro [...].

Essa possível relação entre a evolução temporal e uma maior intensidade dos sintomas da Dengue apontada pelos Enfermeiros também é apresentada na literatura. Teixeira et al. (2015), ao discorrerem sobre a epidemiologia da doença no mundo, nas Américas e no Brasil, apresentam dados que revelam um agravamento da sua expressão clínica no decorrer do tempo. Ou seja, com o passar dos anos, têm sido registradas epidemias de Dengue de intensidade progressivamente maior (TEIXEIRA et al., 2015; SOUZA; HOTTZ, 2015).

Existem diferentes hipóteses explicativas para a ocorrência das formas graves de Dengue (ROSEN, 1977; HALSTEAD, 1970; 1982; KOURI et al., 1987; FIGUEIREDO, 1999; BARRETO; TEIXEIRA, 2008). Segundo Rosen (1977), o aparecimento da Febre Hemorrágica da Dengue (FHD) está relacionado à virulência da cepa infectante, ou seja, as formas mais graves são resultantes de cepas extremamente virulentas.

Já Halstead (1970; 1982), relaciona a FHD com infecções sequenciais por diferentes sorotipos do vírus da Dengue; desse modo, a resposta imunológica na segunda infecção é exacerbada, o que ocasiona a forma mais grave da doença (FIGUEIREDO, 1999; BARRETO; TEIXEIRA, 2008; PARANÁ, 2015; PATOLOGIA DE FEBRES..., 2015).

Uma terceira abordagem, proposta por Kouri et al., (1987), constitui numa hipótese integrada, multifatorial e unificadora, em que se acrescentam diversos fatores de risco individuais, virais e epidemiológicos às teorias da virulência da cepa de Rosen (1977) e das infecções sequenciais de Halstead (1970; 1982). A interação 
desses fatores de risco é que promoveria as condições para a ocorrência das formas graves da Dengue (KOURI et al., 1987; FIGUEIREDO, 1999; BARRETO; TEIXEIRA, 2008; PARANÁ, 2015; PATOLOGIA DE FEBRES..., 2015).

Como exemplos de fatores individuais são apresentados: menores de 15 anos e lactentes; adultos do sexo feminino; raça branca; bom estado nutricional; presença de enfermidades crônicas; preexistência de anticorpos; e intensidade da resposta imune anterior. Já dentre os fatores virais, são descritos os sorotipos circulantes e a virulência das cepas (KOURI et al., 1987; PARANÁ, 2015; PATOLOGIA DE FEBRES..., 2015).

Por fim os fatores epidemiológicos, relacionam-se com: existência de população susceptível; circulação simultânea de dois ou mais sorotipos; presença de vetor eficiente; alta densidade vetorial; intervalo de tempo de 3 meses e 5 anos entre duas infecções por sorotipos diferentes; sequência das infecções (DENV-2 secundário aos outros sorotipos); ampla circulação do vírus (KOURI et al., 1987; PARANÁ, 2015; PATOLOGIA DE FEBRES..., 2015).

Não é possível identificar se essa percepção maior dos casos graves em Alfenas guarda relação com os fatores individuais, com as características do agente etiológico, com os aspectos socioambientais favoráveis à proliferação vetorial (SOUZA; HOTTZ, 2015), ou ainda, com a reorganização dos serviços de saúde ocorrida durante a epidemia de 2015, já discutida no DSC "Preocupação e medo". De qualquer forma, o que se nota é um efeito de maior visibilidade para os Enfermeiros da APS do Município sobre a Dengue e sua gravidade.

Nota-se que o significado "Doença grave" é coerente com os aspectos sanitários, epidemiológicos e sociais da Dengue, bem como com as possibilidades de desfecho clínico da doença para a cura ou para a evolução para as formas graves e óbito. Entretanto, não ficou claro se a Dengue foi significada como um problema sério ou se "Doença grave" teve a ver com o aumento do número de casos de Febre Hemorrágica da Dengue (FHD) ou de Síndrome do Choque da Dengue (SCD).

Todavia, independentemente do tipo que entendimento que o sujeito coletivo teve sobre a gravidade da doença, o aspecto convergente foi sobre a atenção necessária para com as medidas preventivas no domicílio. Segundo o DSC: [...] tem que se preocupar mesmo, [...] tomar os cuidados para que ela não aconteça; se 
policiar com coisas simples dentro da nossa casa: evitar deixar água parada nas plantas, na geladeira, no quintal, nos descartáveis que ficam entulhados [...].

Para além dessas atividades relacionadas ao ambiente e que são orientações cotidianas dos Enfermeiros da APS na comunidade, o sujeito coletivo representou a Dengue também no contexto dos seus desejos: [...] Ela significa pra mim uma doença grave, que eu não gostaria de ter, nem que alguém da minha família tivesse [...]. Assim, a Dengue também foi significada como algo indesejado no âmbito pessoal e familiar dos Enfermeiros da APS de Alfenas.

\subsubsection{Doença Causada pela Picada do Mosquito}

Neste DSC, a Dengue é tida como [...] uma doença causada pela picada do mosquito Aedes aegypti [...]. Como explicação para tal significado, são descritos vários condicionantes ambientais, os sintomas mais frequentes, bem como o risco de óbito e a necessidade de que sejam providenciados a notificação, o tratamento e o cuidado adequados aos enfermos.

De acordo com Oliveira (2015a), é possível notar no estudo da história natural dos insetos que os mosquitos constituíram num dos temas primários. Pimenta (2015a) e Teixeira (2001) expõem que até o final do século XIX a teoria dos mosquitos, ou teoria culicidiana - que sucedeu a teoria da transmissão hídrica das doenças - propunha que a condição para a transmissão dos agentes etiológicos era o clima.

No entanto, diante da descoberta do ciclo completo da malária por Ronald Ross em 1898 e mediante a definição das doenças tropicais como categoria, a principal característica atribuída a esse tipo de doenças foi sua transmissão por vetores, dentre estes, os insetos (PIMENTA, 2015a; TEIXEIRA, 2001).

A exemplo das doenças tropicais, a Dengue constitui numa arbovirose transmitida aos homens por mosquitos vetores. A palavra arbovirose deriva-se do inglês Arthropod-Borne Viral Disease, cuja tradução para o português é dada como virose transmitida por artrópodes (CATÃO, 2012).

O vírus da Dengue tem como vetores os mosquitos de três subgêneros do gênero Aedes: Stegomyia, Finlaya e Diceromyia. O Aedes aegypti, o Aedes albopictus e o Aedes polynesiensis são as principais espécies do gênero Stegomyia. 
Dessas espécies, o Aedes aegypti é o vetor responsável pelas epidemias de Dengue no Brasil (CATÃO, 2012).

Em Alfenas, a pesquisa denominada LIRAa, o Levantamento de Índice Rápido de Aedes aegypti, tem colaborado para a identificação dos locais que mantêm focos do vetor da Dengue. No levantamento realizado pela Vigilância Ambiental entre os dias 19 de 23 de outubro de 2015, foi possível identificar focos nos bairros Aparecida, Centro, Chapada, Jardim América, Jardim Nova América, Pinheirinho, Pôr do Sol, Residencial Oliveira, Santa Clara, Vila Betânia, Vila Formosa e Vila Teixeira (ALFENAS, 2015).

Dentre os locais pesquisados, $80 \%$ dos focos foram encontrados em residências urbanas. Exemplo disso é que em relação aos tipos de depósitos predominantes se destacaram os reservatórios intradomiciliares como os depósitos móveis (vasos e pratos de plantas) e os depósitos fixos, como ralos, tanques e tambores. Segundo a Secretaria Municipal de Saúde de Alfenas (ALFENAS, 2015), esses dois tipos de depósitos estiveram presentes em mais de $68 \%$ dos focos observados.

Não se pretende discutir os aspectos entomológicos envolvidos na transmissão e no controle da Dengue, nem tampouco sobre a biologia e o comportamento do vetor. A ideia aqui é apontar que o conhecimento científico e empírico acumulado sobre a questão vetorial da Dengue certamente contribuiu para e elaboração do significado "Doença causada pela picada do mosquito".

Não há dúvidas de que o mosquito seja um elemento de extrema importância na cadeia de transmissão da Dengue e que para controlar a doença é necessário conter a reprodução e a dispersão do Aedes aegypti, seu vetor principal. Contudo, uma preocupação relacionada ao conteúdo deste DSC é a concepção da Dengue do ponto de vista estritamente ecológico, como proposto na tríade ecológica para a determinação das doenças.

Foi apresentada na discussão de um significado anterior, a necessidade de se enxergar a Dengue como um problema de saúde coletiva e não apenas como um problema de saúde pública. Agora, diante do DSC "Doença causada pela picada do mosquito", surge a necessidade de outra mudança epistemológica: a de abordar a Dengue numa perspectiva de causalidade mais atual e abrangente.

O fato de a Dengue ser um problema essencialmente coletivo requer imaginála para além da categoria das doenças tropicais. Nesse sentido, o grande desafio 
para a Saúde Coletiva constitui em pensar e em trabalhar as condições sociais e os determinantes sociais da saúde como parte de um modelo que compreenda toda a complexidade inerente ao processo saúde-doença da Dengue na atualidade (PIMENTA, 2015b).

\subsubsection{Epidemia}

No discurso referente ao significado "Epidemia", o coletivo dos Enfermeiros descreveu uma mudança no padrão epidemiológico da Dengue em Alfenas. Segundo o DSC: [...] A Dengue se tornou um caso de epidemia. [...] Nós enfrentamos uma guerra com a Dengue aqui nesses últimos meses; já se tornou caso sério dentro da saúde pública. Eu acho que a Dengue é isso para mim hoje: uma epidemia! [...].

Um estudo epidemiológico sobre a Dengue em Alfenas registrou que, entre os anos de 2001 e 2010, ocorreram 489 notificações da doença. Das notificações de casos urbanos, percebeu-se que $37,18 \%$ resultaram na confirmação de Dengue Clássico, o que correspondeu a 177 indivíduos. As taxas de incidência mais expressivas foram observadas nos anos de 2002, 2007 e 2010. Nesse período, não foram identificadas formas graves da doença nem evolução dos casos para óbito por Dengue (NASCIMENTO; RODRIGUES-JÚNIOR; RODRIGUES, 2015; NASCIMENTO; RODRIGUES-JÚNIOR, 2014).

Nos cinco anos subsequentes, o que se notou foi uma distribuição atípica e crescente da incidência de Dengue no Município. Foram 17 casos confirmados em 2011; 22 casos em 2012; 176 doentes em 2013; e 270 indivíduos positivos em 2014. Já de janeiro a cinco de novembro de 2015, foram observadas 2951 notificações de Dengue, sendo que 2884 suspeitas se referiram a residentes. Dos possíveis casos autóctones, 523 foram descartados; 324 ainda estavam aguardando os resultados para classificação final; e expressivos 2037 casos já haviam sido confirmados (ALFENAS, 2015; RODRIGUES, 2015). ${ }^{2}$

Outro aspecto que chama a atenção é que de 2001 a 2010 houve anos sem casos confirmados no Município, como os de 2004, 2005 e 2009. Já de 2011 a 2015, não houve um ano sequer sem a confirmação da doença. Em comparação ao 
penúltimo ano considerado a taxa de Incidência de Dengue evoluiu de 347,86 (por 100.000 hab.) em 2014, para 2587,92 (por 100.000 hab.) em 2015 (NASCIMENTO, 2011; RODRIGUES, 2015). Esses aspectos epidemiológicos reforçam que a Dengue em Alfenas tem passado de uma doença com distribuição pouco expressiva para uma epidemia séria em nível local.

Bonita (2010, p. 119) define epidemia como "a ocorrência em uma região ou comunidade de um número de casos em excesso, em relação ao que normalmente seria esperado". À primeira vista, essa definição vai ao encontro do significado apresentado pelos Enfermeiros da APS e da situação epidemiológica da Dengue em Alfenas, onde tem sido notória a evolução gradativa das taxas de incidência da doença.

Uma reflexão à parte, no entanto, tem a ver com o atual padrão de distribuição da Dengue em Alfenas. Considerando a presença marcada pelo mosquito Aedes aegypti em todos os bairros urbanos, confirmada pelos índices de infestação predial e pelas taxas de incidência crescentes nos últimos anos, não estaria Alfenas próxima de ser considerado um Município endêmico para Dengue?

Rezende (1998) explica que, ao tentar diferenciar epidemia de endemia, corre-se o risco de pensar que a epidemia se caracteriza pela incidência, em curto período de tempo, de grande número de casos de uma doença, ao passo que a endemia se traduz pelo aparecimento de menor número de casos ao longo do tempo. Entretanto, segundo o autor, essa distinção não pode ser feita com base somente na maior ou menor incidência de determinada enfermidade em uma população. $O$ que define o caráter endêmico de uma doença é o fato de esta ser peculiar a um povo, país ou região.

De forma corroborativa, Bonita (2010, p. 121) argumenta que as doenças transmissíveis são denominadas "endêmicas quando em uma área geográfica ou grupo populacional apresenta um padrão de ocorrência relativamente estável com elevada incidência ou prevalência". No caso da Dengue, as áreas endêmicas são limitadas por vezes pelas condições climáticas. No entanto, conforme bem lembram McMichael et al. (2003), o aquecimento global está alterando o clima e contribuindo para o surgimento de áreas endêmicas.

Embora a infecção por Dengue ainda seja predominante nas grandes cidades e o município de Alfenas tenha sido classificado nos últimos anos como de médio 
risco para a transmissão da doença, o movimento e a expansão gradativos dessa virose para localidades de menor porte é preocupante (TEIXEIRA et al., 2015).

Outro aspecto importante levantado pelo sujeito coletivo foi a da circulação viral no nível local: [...] temos que enfrentar cada ano um tipo de vírus diferente [...]. Esse relato converge para a constatação de que "a maioria dos inquéritos sorológicos demonstra que o vírus Dengue circula em todos os espaços urbanos, embora com diferentes intensidades" (TEIXEIRA et al., 2015, p. 301). No entanto, essa ideia não é consenso entre os pesquisadores.

Não se sabe ao certo quais os determinantes para a introdução de diferentes sorotipos da Dengue no Município. Todavia, uma hipótese a ser clarificada é de que o alto fluxo de estudantes universitários que compõe uma população flutuante em Alfenas tenha contribuído para a incidência de casos alóctones e consequente veiculação de cepas virais distintas no local.

\subsubsection{Culpabilidade}

No terceiro eixo de discussão, são analisados os significados que emergiram como transferência de culpa a respeito da Dengue. Os DSCs "Descuido das pessoas" e "Consequência da falta de educação" são comentados a seguir.

\subsubsection{Descuido das Pessoas}

De acordo com os entrevistados, a Dengue significa um descuido das pessoas: [...] eu acho que é descuido das pessoas [...]. Segundo esse DSC, a falta de cuidado da população com os resíduos, com as sobras de alimentos e a falta de destino adequado para o lixo constituem fatores causais para a disseminação da doença. Desabafa ainda: [...] você dá as orientações, se passar daqui 15 dias está lá o lixo de novo [...].

$\mathrm{Na}$ visão do sujeito coletivo, esse comportamento contribui para a coleção de água parada e consequente desenvolvimento da larva e do mosquito responsável pela transmissão da Dengue. Dessa forma, apontam o cuidado com o asseio e com o manejo adequado do lixo como uma forma possível de prevenção: [...] se a gente trabalhasse melhor a higiene, os rejeitos de lixo, poderia evitar [...]. 
A relação entre Dengue e o lixo doméstico também foi observada nas representações sociais dos moradores do Município de São Sebastião, Estado de São Paulo. Os discursos da população foram marcados pela presença de menções aos criadouros do mosquito no lixo, citados por eles como recipientes. Essa associação positiva do lixo com a doença foi registrada em $78 \%$ dos entrevistados. Para os autores, tal achado sugere a existência de conhecimento popular sobre a doença e sobre o saneamento do meio ambiente (LEFEVRE et al., 2007).

Outro resultado interessante daquele estudo foi o reconhecimento pela própria população da sua falta de colaboração. O DSC com mais alto grau de compartilhamento da ideia entre os entrevistados foi o que afirmava que os moradores poderiam colaborar mais no controle da Dengue e do vetor. A justificativa para a falta de participação popular e para a irresponsabilidade no controle do mosquito foi que as pessoas não estavam nem aí (LEFEVRE et al., 2007).

A ideia da Dengue como fruto de atitudes negativas da população também foi identificada em outros trabalhos sobre representações sociais da doença. Num estudo sobre fatores contribuintes para a ocorrência da Dengue, um dos DSCs intitulado "Falta de cuidado da população com o ambiente em que vive" representou o comportamento desleixado das pessoas em relação ao cuidado com o meio ambiente (REIS; ANDRADE; CUNHA, 2013).

Reis, Andrade e Cunha (2013) discutiram alguns aspectos comuns aos resultados deste trabalho. De modo semelhante, foi registrado o descaso da população com o seu entorno, o comodismo como parte dos hábitos e da cultura, bem como a resistência das pessoas para com as orientações fornecidas pelas Equipes de Saúde da Família.

O posicionamento de responsabilização da população pro que se refere à falta de cuidado com o ambiente permeou o discurso coletivo de todos os profissionais da Estratégia Saúde da Família entrevistados naquela ocasião. No entanto, foi interessante notar que a enfermagem, representada por 16 profissionais de nível superior, foi a única categoria profissional que representou o aspecto do descuido em 100\% das suas citações (REIS; ANDRADE; CUNHA, 2013).

Acredita-se que essa questão da falta de cuidado como fator causal da Dengue tenha relação com a perspectiva com que essa categoria profissional enxerga as suas atribuições e responsabilidades diante da enfermidade. $O$ objeto de trabalho dos Enfermeiros é o cuidado aos indivíduos e à coletividade. Assim, pode 
ser que esse aspecto formativo e laboral tenha contribuído para o pensamento de que a ausência dessa conduta no cotidiano da população seja preponderante para o surgimento do agravo à saúde.

\subsubsection{Consequência da Falta de Educação}

Já neste significado, a Dengue é representada como um produto da falta de educação em nível individual e coletivo: [...] falta de educação do indivíduo. [...] Eu diria que a Dengue é uma consequência da má educação da população. Nesse sentido, os Enfermeiros citaram uma preocupação com os imóveis desocupados, como os lotes sujos, por exemplo: [...] Esses terrenos abandonados... Do lado da minha casa eu já fiz inúmeras denúncias pra prefeitura, a prefeitura notifica o dono do terreno, ele vai lá, dá uma limpadinha [...].

Um aspecto desse DSC que é semelhante ao apresentado no significado "Descuido das pessoas" refere-se ao manejo e destino inadequado do lixo pela população. Entretanto a justificativa para o significado "Consequência da falta de educação" esteve mais relacionada à formação das condutas, aos costumes, às habilidades e ao bom senso das pessoas: [...] Tudo consequência do nosso desenvolvimento precário; consequência da má educação, dos maus hábitos, do não treinamento, ou da falta de consciência [...].

A falta de educação como determinante da Dengue também foi representada pelo imaginário coletivo de outros atores da Atenção Primária à Saúde. Profissionais da Estratégia Saúde da Família sul mato-grossenses referiram-se à educação informal, proveniente da família e do meio social para explicar a "Falta de cuidado da população com o ambiente em que vive". A citação nesse contexto foi mais uma colocação sobre os maus hábitos e sobre a falta de educação para a cidadania do que sobre a falta de educação formal propriamente dita (REIS; ANDRADE; CUNHA, 2013).

A dificuldade com o manejo e destinação adequados do lixo foi citada pelos Enfermeiros da APS tanto no DSC sobre o "Descuido das pessoas" quanto no DSC "Consequência da falta de educação". Achado análogo foi descrito por Reis, Andrade e Cunha (2013) quando também apontaram a "presença de lixo a céu aberto e de terrenos baldios utilizados como depósito de lixo" como parte das representações sociais dos profissionais da ESF sobre a Dengue. 
A diferença foi que em Alfenas o sujeito coletivo explicitou que o trabalho de limpeza dos terrenos abandonados tem sido realizado pelos Agentes de Controle de Endemias (ACE): [...] Eu estava conversando com uma Agente de Controle de Endemias e ela falou que o serviço dela é catar lixo do quintal das pessoas [...]. No contexto da citação ficou claro o tom de indignação do entrevistado com o descaso dos proprietários de imóveis baldios, cujo lixo exposto tem servido como criadouros do mosquito Aedes aegypti.

No trabalho de Reis, Andrade e Cunha (2013), essa questão foi identificada como falha de estrutura e de fiscalização por parte dos órgãos responsáveis. $\mathrm{Na}$ microrregião de Dourados (MS), a manutenção dos terrenos limpos - para a qual não há parcerias entre os setores do poder público - foi representada pelos profissionais como responsabilidade dos gestores.

Já em Alfenas, o sujeito coletivo sinalizou para a Prefeitura Municipal apenas como um órgão fiscalizador: [...] Do lado da minha casa eu já fiz inúmeras denúncias pra prefeitura, a prefeitura notifica o dono do terreno, ele vai lá, dá uma limpadinha [...]. Ou seja, para os Enfermeiros da APS, o cuidado ambiental nos terrenos é um dever do proprietário do imóvel. Nesse sentido, a Dengue é vista Dengue como consequência da falta de educação, uma vez que é determinada pela falta de responsabilidade do munícipe para com o microambiente em que vive.

Esse é um pensamento particularmente perigoso do ponto de vista da determinação social da Dengue. Ao mesmo tempo em que a ideia "Consequência da falta de educação" inclui um aspecto fundamental para o desenvolvimento de uma comunidade que é a própria educação, o discurso mostra-se permeado por outra questão já bastante criticada que é a postura de "culpabilização" da vítima (PIMENTA, 2015a; DAVID; MARTELETO, 2012; FRANCA et al., 2002; OLIVEIRA, 1998; VALLA, 1993).

Essa postura, que tem norteado de forma indireta a maioria das campanhas midiáticas sobre o controle do mosquito vetor, é criticada na literatura tanto pelo movimento de transferência de responsabilidades quanto pela visão individualista e simplista sobre as determinações do processo saúde-doença (PIMENTA, 2015a).

É claro que "a questão do controle vetorial é hoje um dos pontos-chave na discussão do controle da Dengue", entretanto a suposta falta de consciência da população e a consequente ausência de ajuda na limpeza de casas, de quintais e de 
jardins não deveriam ser vistos como os únicos pontos frágeis das estratégias de combate aos focos do mosquito (PIMENTA, 2015a, p. 39).

Ou seja, a Dengue não deve continuar sendo representada exclusivamente como produto do mau comportamento das pessoas. De acordo com Pimenta (2015a, p. 32):

[...] questões estruturais de condições de vida e dos determinantes sociais estão por trás dessa discussão, evidenciando problemáticas atreladas a diversas outras esferas, como saneamento básico, abastecimento de água e limpeza pública, muitas vezes diretamente relacionadas à distribuição desigual da verba pública [...].

Essa percepção ampliada da Dengue no nível micro é de extrema importância porque interfere diretamente nas referências profissionais e comunitárias para 0 controle social e para o enfrentamento da doença (FRANCA et al., 2002). Exemplo disso foi um movimento com caráter de defesa civil popular descrito por Oliveira (1998). A iniciativa de profissionais de saúde (academia e serviços) e membros de organizações populares num dos complexos de favelas no município do Rio do Janeiro surgiu como resultado de discussões sobre a participação popular durante uma epidemia de Dengue.

Naquela ocasião, duas questões levaram as pessoas às ruas: a) o contexto de emergência em que o sistema de saúde não fazia frente à doença de maneira eficaz e a população era quem "precisava tomar medidas de defesa contra a proliferação dos mosquitos". E, b) "as informações divulgadas pelo governo mascaravam a realidade, pois referiam-se apenas ao aconselhamento de medidas individuais para evitar a doença". Assim, lutaram pela desconstrução das informações que culpabilizavam a vítima e também pela emersão das condições de vida, de saúde e de seus determinantes para a pauta de discussões da Dengue (OLIVEIRA, 1998, p. 72).

Foi possível observar neste estudo em Alfenas que, em ambos os DSCs relacionados aos aspectos causais da Dengue, os Enfermeiros da APS de Alfenas representaram a "culpabilização" da vítima descrita anteriormente. Entende-se que, embora os entrevistados invariavelmente tenham se incluído na população que necessita mudar seu comportamento diante da enfermidade, os significados "Descuido das pessoas" e "Consequência da falta de educação" configuram um painel de ideias consideravelmente pobre para o pensamento coletivo de profissionais da saúde sobre a Dengue. 
É possível refletir que a culpabilização da vítima seja uma "cortina de fumaça" para desviar o foco inquisidor do poder público, que é responsável pelo provimento de ambientes saudáveis, como um direito constitucional difuso, uma vez que o problema da Dengue também está ligado à degradação do meio ambiente. A estratégia de controle e erradicação dos nichos é a chave dos programas desenvolvidos, mas, mesmo que isso fosse possível, a consequência, dentro de um paradigma ecológico, é que se criaria um vazio no ecossistema, que seria ocupado por outro agente ou vetor, desconhecido, que poderia transmitir outra doença, ou não. Não é possível saber antecipadamente.

\subsubsection{Outros}

No último eixo de discussão sobre o que a Dengue significa para os Enfermeiros da APS de Alfenas, são tecidos comentários sobre ideias centrais diversas que não foram incluídas nos demais agrupamentos semânticos. Os DSCs "Outros significados", "Doença de país pobre", "Mais uma doença pra gente cuidar" e "Uma guerra" são analisados a seguir.

\subsubsection{Outros Significados}

Outro significado emerso para a Dengue foi o de uma "Doença de país pobre": [...] Eu diria que a Dengue é uma doença de país pobre, que infelizmente a gente está vivenciando nos dias atuais [...]. Olhando para a distribuição global de países ou área sob risco de transmissão de Dengue em 2011 (WHO, 2013), nota-se uma suposta delimitação intertropical que caracteriza as regiões favoráveis à sobrevivência de Aedes aegypti.

Segundo Teixeira et al. (2015), a expansão da abrangência da Dengue mundo afora na segunda metade do século XX é notória. Em 1950 viam-se notificações de casos da doença em nove países; já nos dias atuais, mais de setenta países registram casos e aproximadamente cem se encontram infestados pelo principal mosquito vetor. Essa evolução representa um aumento expressivo do número de populações acometidas por epidemias ou sob o risco de serem infectadas pelo vírus da Dengue. 
No caso das doenças tropicais negligenciadas, como a Dengue, é comum o pensamento de estes agravos serem restritos a países cujas condições climáticas e de saúde contribuem para a proliferação dos organismos e seus vetores. Entretanto, uma série de trabalhos publicados na Revista The Lancet Infectious Diseases chama a atenção para a necessidade iminente de reavaliar algumas ideias clássicas sobre a distribuição destas doenças (THE LANCET..., 2014).

Em 2010, algumas transmissões autóctones de Dengue foram registradas na França e na Croácia. Em 2012 houve um surto de Dengue na Região Autónoma da Madeira em Portugal, com mais de 2200 casos, o que alimentou temores de que outras arboviroses tropicais também chegassem à Europa. Foi o que aconteceu na comunidade espanhola da Catalunha, onde tem sido registrado um aumento gradativo da incidência de Dengue e Chikungunya, principalmente na região norte de Barcelona (SCHAFFNER; FONTENILLE; MATHIS, 2014; SCHAFFNER; MATHIS, 2014; THE LANCET..., 2014; VALERIO et al., 2015).

Dentre outros exemplos dessa ameaça em continentes com países desenvolvidos, podem-se citar ainda os casos de Dengue no Japão, que registrou em setembro de 2014 seu primeiro surto desde o ano de 1945; as evidências de Dengue endêmica em família ricas na Austrália; também os casos de febre chikungunya nos Estados Unidos (EUA) em julho de 2013, que acabaram contribuindo para a incursão de outras doenças tropicais negligenciadas, dentre estas, a Dengue, agora endêmica no país (NELSON, 2014; PIMENTA, 2015b; THE LANCET..., 2014).

Que a Dengue ainda se faz mais presente nos países em desenvolvimento não é novidade (WHO, 2013). Entretanto, as alterações climáticas e a crescente migração são exemplos de fatores que podem ampliar o alcance geográfico de muitas doenças tropicais negligenciadas (THE LANCET..., 2014). Alguns pesquisadores associam a Dengue à urbanização em vez de considerá-la uma doença da pobreza (PIMENTA 2015b). Essas observações sobre a ocupação populacional do espaço e do "movimento" das doenças tropicais faz repensar o significado da Dengue como uma doença de país pobre.

Ainda no DSC sobre "Outros significados", a Dengue também foi representada como "Mais uma doença pra gente cuidar": [...] Porque a gente cuida do paciente; fica atento, fica lembrando daquela pessoa. Mudou do ano passado pra 
cá, essa atenção... Antes era um caso ou outro que você nem ficava sabendo; mas a partir do momento que o paciente veio, a gente sentiu que precisava cuidar [...].

Nesse sentido, o sujeito coletivo aponta novamente para a mudança já descrita da demanda dos casos suspeitos de Dengue na Atenção Primária do Município. A maior procura desses usuários durante a epidemia de 2015 em comparação à demanda espontânea dos anos anteriores causou lotação nas Unidades de Saúde e consequente atenção e senso da necessidade de cuidar por parte dos Enfermeiros.

Ainda como resultado do seu caráter polissêmico, a Dengue também foi vista como "Uma guerra": [...] E mais, pra mim, a Dengue é uma guerra! Porque cada época é algo diferente; sintomatologia diferente, de paciente pra paciente, de ano pra ano. Uma guerra que nós Enfermeiros e todos da área de saúde temos que enfrentar. Não só no dia-a-dia, mas estudar, porque que o ano que vem vai ser outro tipo; a gente fica realmente preocupada com essa epidemia [...].

Nesse contexto, a Dengue foi representada como um desafio profissional. Diferentemente do emprego usual da palavra "guerra" para descrever o "combate" ao mosquito transmissor, o aspecto quase militar aqui destacado pelos Enfermeiros diz respeito mais ao atendimento dos pacientes. Segundo o sujeito coletivo, a dinamicidade das manifestações clínicas, caracterizada pelas alterações observadas caso a caso no decorrer do tempo, é um aspecto que gera preocupação. O lado positivo desse significado refere-se à sua capacidade de despertar a atenção para 0 problema e de suscitar a necessidade de atualização "bélica/profissional" do grupo.

Assim, os significados da Dengue representados pelos Enfermeiros da Atenção Primária à Saúde de Alfenas foram: "Desconforto enorme"; "Problema de saúde pública"; "Descuido das pessoas"; "Consequência da falta de educação"; "Doença viral"; "Preocupação e medo"; "Doença grave"; "Doença causada pela picada do mosquito"; "Epidemia"; e "Outros significados". Esses achados simbólicos e figurativos, clarificados pela discussão dos Discursos do Sujeito Coletivo, evidenciam o quão polissêmico e multifacetado é o tema Dengue na atualidade.

\subsection{DIFICULTADORES PARA O CONTROLE DA DENGUE}

Dos discursos dos Enfermeiros da APS de Alfenas em relação aos dificultadores para o controle da Dengue, emergiram as seguintes ideias centrais: 
"Falta de conscientização da população"; "Resistência e falta de responsabilidade das pessoas"; e "Muitas questões".

Os discursos referentes à "Falta de conscientização da população"; "Resistência e falta de responsabilidade das pessoas"; e até mesmo alguns trechos do depoimento coletivo sobre "Muitas questões", reforçam a ideia comportamental da falta de colaboração da população no controle da doença. Seja por questão de consciência, de resistência ou de responsabilidade das pessoas, ambos os DSCs expuseram o pensamento de transferência de responsabilidade para a população.

Para além desses aspectos outrora discutidos nos tópicos "Descuido das pessoas" e "Consequência da falta de educação" na dimensão dos significados da Dengue, o que se nota em relação ao DSC "Falta de conscientização da população" é que a visão dos Enfermeiros acerca dos moradores foi tão negativa que até possíveis facilitadores para o controle da Dengue foram precocemente vistos como prováveis dificultadores.

Refere-se aqui ao desenvolvimento de imunobiológicos contra a doença: [...] Talvez a vacina vá até dificultar porque as pessoas vão achar que estão imunizadas e só vai piorar [...]. O mesmo tom de desmotivação em relação ao enfrentamento da Dengue também pode ser percebido no trecho: [...] Até o profissional de saúde às vezes fica descrente: "ah, vou orientar as mesmas coisas" [...]. É o descrédito das instituições.

No entanto, em meio ao discurso pessimista, são observados de forma conflitante sinais de boa vontade pela causa e de esperança por resultados melhores: [...] Mas a gente tem que trabalhar a conscientização, a educação e a prevenção de danos. [...] E é um trabalho de formiguinha, tem que persistir, continuar o resto da vida; até as pessoas conseguirem entender que é dessa forma que a gente vai erradicar [...].

A questão da falta de conscientização da população também foi observada por Reis, Andrade e Cunha (2013), ao estudarem as representações sociais dos profissionais de Equipes de saúde da família sobre fatores contribuintes para a ocorrência da Dengue. Segundo tais autores, essa conscientização necessária não é um processo tão elementar porque não depende apenas do conhecimento transferido da equipe para a comunidade, mas da experiência das próprias pessoas com o processo saúde-doença. 
Por isso, a orientação e a limpeza realizada pelos profissionais de saúde nem sempre contribuem para uma "postura permanente de conservação do meio" nem para uma adoção de "hábitos higiênicos" por parte da população. De acordo com o relato das equipes, essa é uma situação de difícil reversão porque o setor saúde não tem conseguido alcançar e mudar o comportamento humano (REIS; ANDRADE; CUNHA, 2013, p. 521).

No DSC sobre a "Resistência e falta de responsabilidade das pessoas" podem-se observar novas críticas à população no que se refere à falta de cidadania e de adesão às orientações fornecidas: [...] Eu acredito que o que dificulta o controle da Dengue é a resistência das pessoas em cuidar do seu pedaço, da sua casa. [...] é falta de responsabilidade [...] como cidadão, de pensar no próximo, de ouvir as orientações que são dadas através da televisão, dos agentes de endemias que fazem a visita [...].

Aspecto semelhante também foi registrado por Reis, Andrade e Cunha (2013) em relação à resistência à visita domiciliar e à falta de cuidado da população com o ambiente em que vive. Os entrevistados referiram que algumas famílias apresentam barreiras para a realização da visita quando o assunto é Dengue. Segundo os autores, nesta abordagem que envolve higiene e o cuidado no armazenamento de vasilhames, um primeiro contato inadequado, normativo e excessivamente enfático pode ocasionar resistência a ações futuras.

A vasta referência à população como alheia ao enfrentamento da Dengue, mesmo diante de tanta informação e orientação em saúde, remete à fraca correlação existente entre o conhecimento e a mudança de comportamento (JARDIM; SCHALL, 2015; WHO, 1995). Diante disso, fica evidente a necessidade de se buscar estratégias de cunho psicológico para auxiliar na mudança de hábitos, que, por se tratar de comportamentos prejudiciais, podem ser entendidos como vícios sociais da saúde a serem superados.

O DSC "Muitas questões" trouxe de forma sintetizada alguns macro e microdeterminantes importantes para o contexto da Dengue. O sujeito coletivo apresentou como dificultadores para o controle da doença o clima, a região geográfica e 0 comprometimento das pessoas. A explicação sobre o comprometimento abordou duas visões interessantes: o envolvimento profissional e a participação da comunidade. 
Em relação ao aspecto comunitário, não houve diferença entre os discursos anteriores sobre a baixa adesão das pessoas às orientações fornecidas como principal dificuldade. Já no que se refere ao envolvimento e ao comprometimento profissional, notou-se no DCS uma explicação mais voltada para uma atribuição dos gestores, ou seja, o provimento de recursos: [...] tem que ter recursos humanos e infraestrutura pra trabalhar [...].

Segundo as diretrizes para a organização dos serviços de atenção à saúde em situação de aumento de casos ou de epidemia de Dengue, a organização do processo de trabalho e a estrutura mínima dos serviços são abordadas de forma clara como necessidades da Atenção Primária à Saúde e dos outros níveis de assistência (BRASIL, 2013). Embora essas recomendações tenham a ver com a atenção aos pacientes já acometidos pela Dengue, o sujeito coletivo apontou a ausência de recursos como dificultadores também para o controle da doença.

No que se refere aos dificultadores "Alta proliferação do mosquito" e "Grande quantidade de foco", o discurso foi construído nos moldes da abordagem entomológica: [...] Todo mundo tem reservatórios de água em casa, por mais que cuide. Acho que tem que acabar com o mosquito mesmo pra acabar com a doença, não tem outro jeito [...].

A participação do artrópode Aedes aegypti no ciclo infeccioso da Dengue e sua capacidade de adaptação, de proliferação e de distribuição no meio urbano são amplamente descritos na literatura. A apresentação de Oliveira (2015b) sobre a competência vetorial, bem como outras diversas características das populações de mosquitos, fazem relembrar que os próprios aspectos entomológicos constituem, de fato, em dificultadores para o controle da doença.

Sobre "Boatos": [...] saiu um boato que tinha um ladrão vestido de agente de endemia entrando nas casas; acho que isso cria medo e resistência na população, daí a pessoa não deixa os agentes de saúde entrar [...]. Não bastassem os inúmeros fatores que atrapalham o trabalho de controle da Dengue, a disseminação de informações falsas para a população surgiu como uma especificidade local que, segundo o DSC, dificulta o enfrentamento da doença.

A ideia "Não saber a causa" também compôs o agrupamento de questões representadas como forças restritoras. Segundo o DSC, parece não haver uma comunicação efetiva entre o setor de vigilância epidemiológica e as Unidades de Atenção Primária Saúde: [...] Outra dificuldade é você não saber o que está 
causando o maior número de casos naquele lugar. [...] $A$ epidemiologia não me apresentou nada; se fizeram estudo, se já chegaram a alguma conclusão. $O$ que dificultou o controle daqui? Eles encontraram mais o quê nas casas? Onde que está o maior foco? Por quê? Eu não tive. [...] você tem que saber a causa pra poder combater [...].

Nesse discurso, é vista nítida transferência de responsabilidades de profissionais para outros profissionais do setor saúde. Não foi possível identificar onde está o nó do fluxo de informações dentro da Secretaria Municipal de Saúde de Alfenas. Entretanto, o que se sabe é que a Coordenadoria de Vigilância Epidemiológica trabalha com levantamentos e divulga regularmente os dados epidemiológicos da Dengue. Seja por meio de mapas ou de informes técnicos, a evolução da infestação predial, dos tipos de criadouros, do número de notificações, de casos confirmados, de casos descartados e em investigação é acompanhada e comunicada em nível local (ALFENAS, 2015).

Talvez a discordância seja explicada pelo grau de detalhamento geográfico das informações. A unidade de análise espacial utilizada para as publicações tem sido os bairros urbanos em vez das áreas de abrangências das Unidades de Saúde da Família. No entanto, é possível notar que existe uma semelhança de quase sobreposição entre as delimitações dos bairros com os limites de atuação das Equipes de Saúde da Família no Município (NASCIMENTO; RODRIGUES-JÚNIOR, 2011; NASCIMENTO, 2011; ALFENAS, 2015). Dessa maneira, a Distribuição Espacial dos Focos de Aedes aegypti por tipo de depósito referentes ao 3ㄴ LIRAa de 2015, por exemplo, demonstra que é possível, sim, conhecer o que tem sido encontrado e os locais com maior concentração de focos pelo território (ALFENAS, 2015).

Já em relação ao dificultador "Falta de informação sobre a doença em sí", o sujeito coletivo faz menção a uma suposta falta de noção das pessoas em relação à complexidade/gravidade da Dengue. Segundo o DSC: [...] A pessoa pensa que é o mosquitinho que pica e que você vai ter uma dorzinha, que é uma coisa passageira, não tem ideia do que realmente é a Dengue, da complexidade da doença [...]. O sujeito coletivo clarifica que as informações a respeito da prevenção e dos sintomas já foram saturadas e que a necessidade atual é de expor mais sobre a doença e suas consequências. 
Interpretando o exposto como se a população não conhecesse ou considerasse a Dengue como uma doença grave, tal dificultador esbarra em achados divergentes da literatura. LEFEVRE et al. (2007) e Villela e Almeida 2013 registraram em populações e em locais de estudo distintos que a maioria das pessoas já ouviram sobre a Dengue e a representam como uma doença grave e perigosa por diversos motivos. Entretanto, respeitando o contexto de produção das representações sociais na realidade cotidiana, não há elementos para questionar a plausibilidade da ideia do desconhecimento populacional sobre a doença em si como força restritora ao controle da Dengue em Alfenas.

Encerrando o agrupamento que aponta como dificultadores "Muitas questões", foram apresentadas ainda a falta de capacitação dos Agentes de Controle de Endemias (ACE) e a falta de cobrança sobre o trabalho dos Agentes Comunitários de Saúde (ACS). Segundo o DSC, o problema com os ACE não é o quantitativo de recursos humanos, mas a falta de treinamento. Já sobre os ACS, foi indicada a necessidade de mudança na sua abordagem por ocasião das visitas domiciliares. Segundo o sujeito coletivo, o levantamento das necessidades gerais da população e a prática do agendamento de consultas médicas devem ser incrementados com uma educação permanente/continuada sobre a Dengue.

Tanto os ACE quanto os ACS são profissionais fundamentais para o controle da Dengue em nível local. A integração entre Agente de Controle de Endemias (ACE) e Agentes Comunitários de Saúde (ACS) constitui num passo importante para a otimização de recursos e para possibilitar um maior envolvimento comunitário na prevenção e no controle da doença (CHIARAVALLOTI NETO et al., 2006).

Um estudo sobre a inserção dos também conhecidos como Agentes de Saúde (AS) na Atenção Primária à Saúde do município de São José do Rio PretoSP sinalizou para a complexidade do controle da Dengue nesse nível de atenção que é permeado por questões socioambientais e por ações intersetoriais (CESARINO et al., 2014).

Entretanto, apesar de expor as dificuldades, o trabalho de Cesarino et al. (2014) também revelou e enfatizou diversas possibilidades de atuação dos AS (ou ACE) e a viabilidade da sua inserção nas Unidades Básicas de Saúde. Acredita-se que iniciativas integradoras como a descrita tenham potencial de melhorar a qualidade do processo de trabalho em prol do controle da Dengue de ambas as categorias profissionais. 


\subsection{FACILITADORES PARA O CONTROLE DA DENGUE}

Em relação aos facilitadores para o controle da Dengue, emergiram as seguintes ideias centrais: "Trabalho de orientação e conscientização"; "Educação da população"; "Consciência das pessoas"; "Saneamento básico"; "Parcerias"; "Não há facilitadores"; "Informações"; e "Diversos facilitadores".

Os DSCs sobre "Trabalho de orientação e conscientização" e "Informações" fazem menção às atividades que já estão sendo desenvolvidas no Município de Alfenas. São exemplificadas as ações educativas nas escolas com crianças, na comunicação impressa, na mídia televisiva, na internet com as redes sociais e nos encontros cotidianos pessoa a pessoa dos ACS e dos ACE durante as visitas domiciliares.

Como um significado apresentado para a Dengue foi "Consequência da falta de educação", não causa estranhamento notar que a "Educação da população" e a "Consciência das pessoas" foram representadas como facilitadores para o controle da doença. Novamente, a educação e a consciência apareceram no sentido das condutas, dos hábitos das pessoas e do exercício da cidadania. Ou seja, o que facilita é a educação informal e a consciência/comprometimento individual que podem ou não ter a ver com o nível de instrução ou de escolaridade.

Já o "Saneamento básico", foi apontado como um possível facilitador. Isso porque, pelo discurso, dá pra perceber colocações prospectivas ou projetivas sobre a necessidade de superar a dificuldade da falta de saneamento: [...] O que vai facilitar é melhorar a questão de saneamento básico, porque é uma doença primária, uma coisa muito básica; tem que acabar, não pode continuar [...].

Um estudo sobre a Dengue e aspectos socioeconômicos do Município mostrou que as variáveis sobre água encanada, esgotamento sanitário e coleta regular de lixo nos domicílios foram as que apresentaram menor relevância na classificação socioeconômica realizada. Durante o trabalho, foi possível observar que o saneamento básico está presente am quase 100\% dos domicílios Alfenenses (IBGE, 2015; NASCIMENTO; RODRIGUES-JÚNIOR, RODRIGUES, 2015).

É reconhecida a interferência das questões estruturais e da salubridade do ambiente na determinação da Dengue. Também é observável que a relação entre Dengue e fatores socioeconômicos ainda permanece como objeto de controvérsia. Entretanto, o fato de Alfenas aparentemente não apresentar indicadores tão ruins de 
saneamento ambiental, leva a crer que o sujeito coletivo desconhece a cobertura de saneamento do Município ou elaborou sua representação baseado em cenários de produção da Dengue diferentes da realidade local.

No que se refere às "Parcerias", o DSC chamou a atenção para uma questão não apenas relevante, mas necessária em qualquer processo de trabalho em saúde pública na atualidade: a intersetorialidade. Uma definição possível para intersetorialidade é a integração de diversos saberes e experiências de sujeitos e serviços sociais distintos que colaboram para o enfrentamento de problemas complexos, por meio de iniciativas focadas nos interesses coletivos; e que tendem a melhorar a eficiência dos serviços (JUNQUEIRA, 2000; INOJOSA, 2001; NASCIMENTO, 2010; GARCIA et al., 2014).

No contexto das ciências da saúde, um dos sinônimos de intersetorialidade, o termo "ação intersetorial", pode ser entendido como a ação por meio da qual o setor de saúde e os demais setores sociais, tais como, educação, agricultura, indústria, obras públicas e meio ambiente, colaboram para o alcance de uma meta comum, mediante uma estreita coordenação de suas contribuições (DeCS, 2015).

Olhando para a literatura científica, é possível identificar que a intersetorialidade ainda tem sido uma prática incipiente no Brasil. Há trabalhos que apresentam que as ações intersetoriais são importantes para a transformação da realidade local e dos serviços, mas ainda faltam informações sobre a continuidade e a sustentabilidade dos programas (GARCIA et al., 2014).

Entretanto, iniciativas como a da Prefeitura de Belo Horizonte-MG, que adotou uma estratégia intersetorial para o controle da doença no município, mostram que é possível trabalhar de forma integrada, coordenada, colaborativa e coparticipativa. Assim, mesmo que não seja possível observar redução imediata da incidência de um ano para outro, é preciso minimamente reconhecer a importância da abordagem intersetorial para uma contenção parcial da expansão do número de casos e para a solidificação de um espaço coletivo de discussão, de planejamento, de execução e de avaliação das ações (FREITAS, 2011).

Já o DSC que registrou a inexistência de facilitadores, foi interessante por resgatar o já descrito redirecionamento do fluxo de usuários com Dengue no sistema municipal de saúde de Alfenas: [...] Porque o hospital bloqueou lá, não atendeu e acabou que a gente assistiu mais aqui. Das outras vezes, como eram poucos casos, 
nós não tivemos essa visão. Agora dessa vez foi assustador! [...] Então, eu não vejo o que facilitou [...].

A ideia expressa de que "Não há facilitadores" é coerente com os significados "Preocupação e medo", "Epidemia" e parte dos "Outros significados" que apontaram para a Dengue como a causadora de um cenário de guerra nos pontos de atendimento durante o período epidêmico.

A visão dos Enfermeiros nesse DSC que parece reconhecer apenas os dificultadores remete essencialmente à complexidade do combate a Dengue e à necessidade de uma reorganização urgente dos serviços de saúde face à transição epidemiológica da doença no Município. Por outro lado, a história da falta de contato imediato com a Dengue na Atenção Primária à Saúde e o desconhecimento das estratégias e experiências exitosas de controle da doença em nível local podem ser listados como os subsídios prováveis para a inexistência de facilitadores representada.

Como demonstração da diversidade presente nas representações sociais, o último agrupamento de facilitadores vai de encontro à ideia de que "Não há facilitadores" e contrapõe que existem "Diversos facilitadores". Assim, pode ser percebida a possibilidade que o Método do DSC oferece de registrar tanto as similitudes quanto as diferenças que compõem o pensamento social de uma dada coletividade.

O DSC "Diversos facilitadores" foi composto por elementos das ideias centrais "Diversos facilitadores"; "Cobrança"; e "Capacitar e remunerar melhor os ACE". Segundo os Enfermeiros, são importantes para o controle da Dengue: conscientização; trabalho de educação em saúde; propagandas do Governo; trabalho da Vigilância; o recurso do Fumacê; notificação dos casos; trabalho dos gestores; educação; corresponsabilização dos profissionais e indivíduos; cobrança da população; e uma melhor capacitação e remuneração para os ACE.

Aspecto ainda não discutido que merece destaque é a questão do incentivo ou da melhor compensação financeira ao ACE por seu trabalho. Acredita-se que essa ideia, centrada no papel do Agente de Saúde para o controle da Dengue, revela traços da forma fragmentada "como os serviços de controle de endemias encaram esse problema, atualmente" (CESARINO et al., 2014, p. 1030).

Segundo o Coordenador de Vigilância em Saúde de Alfenas, a remuneração dos ACE foi incrementada no decorrer dos últimos anos. Entretanto, de acordo com 
o gestor, essa alteração salarial não parece ter surtido tanto efeito na motivação laboral e pessoal dos profissionais, tampouco se mostrou um facilitador para o controle das epidemias de Dengue no Município (RODRIGUES, 2015).

Cesarino et al. (2014, p. 1030) não entram no mérito da produção recompensada por dinheiro, mas apresentam que a integração dos AS nas UBS pode contribuir para que estes profissionais "portem um olhar ampliado, não focado somente no agravo, merecendo por isso mais reconhecimento e melhores condições de trabalho."

\subsection{SÍNTESE DO MODELO DE CAMPO DE FORÇA}

Um esquema síntese dos dificultadores e dos facilitadores emersos foi elaborado de acordo com o Modelo de Campo Psicológico e com o auxílio da Técnica de Análise de Campo Forças, também provenientes da Psicologia Social. No diagrama exposto na Figura 6, é possível visualizar as forças restritivas e as forças propulsoras para o controle da Dengue apontadas pelo sujeito coletivo de Enfermeiros da APS de Alfenas. 
Figura 6 - Campo de Forças para o controle da Dengue segundo os Discursos do Sujeito Coletivo dos Enfermeiros da APS de Alfenas.

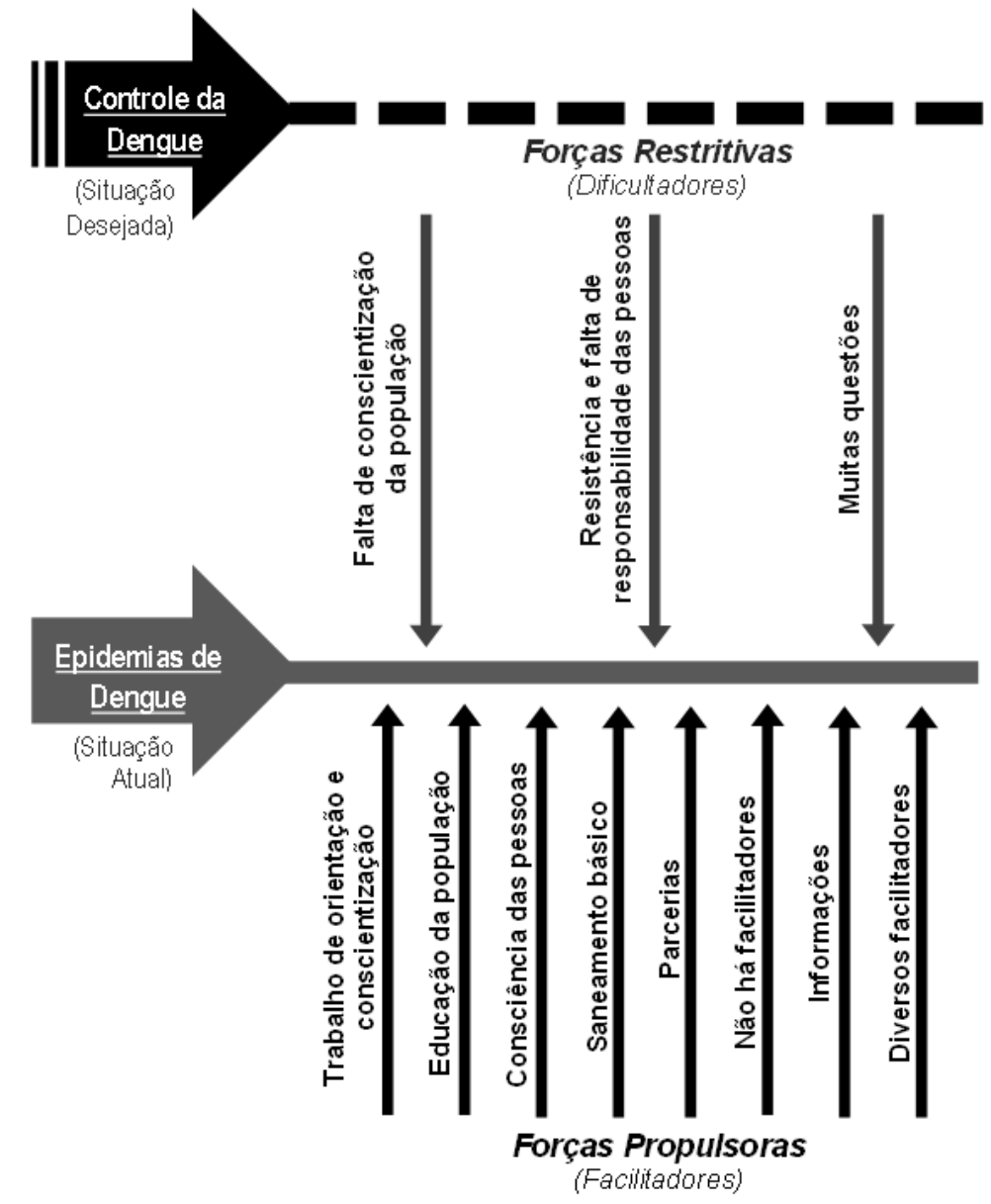

Fonte: Autor (2015).

Pensando em relacionar o Campo de Forças para o controle da Dengue com a abordagem epidemiológica, o Modelo de Campo da Saúde de Lalonde surge como uma proposta interessante para aludir às questões de causalidade. O diferencial da contribuição de Lalonde para o Modelo de Campo da Saúde foi o comprometimento dos serviços de saúde na determinação da saúde e da doença. Essa concepção da organização dos serviços torna-se particularmente apropriada diante da necessidade de uma maior familiaridade da Atenção Primária de Alfenas com a prevenção, com o controle e com o manejo clínico da Dengue.

Em relação às estruturas, aos processos e aos resultados, que envolvem os Serviços de Saúde e interferem no controle da Dengue, foram identificados os seguintes elementos: comunicação intrasetor saúde; informações sobre a prevenção e sobre as consequências da doença; capacitação dos ACE; cobrança dos ACS; trabalho de orientação e de conscientização; existência de parcerias; organização da 
rede assistencial; cobrança dos profissionais à população e tipo de capacitação/remuneração dos ACE. Ainda foram observadas as seguintes ideias: problema de saúde pública, epidemia, doença de país pobre e uma guerra.

Acredita-se que a possível justificativa para as representações tímidas dos enfermeiros da APS registradas sobre a Dengue e sobre seu controle tenha relação com o fato de estes profissionais não estarem até então habituados com epidemias tão expressivas de Dengue no Município. Além disso, foi registrado nos depoimentos individuais a especificidade e a complexidade que saúde coletiva impõe de se trabalhar concomitantemente com um número tão elevado de programas ministeriais voltados a diferentes agravos e grupos populacionais alvo.

A questão do pouco contato com a Dengue nas UBS, primeiramente justificada pela vasta abrangência das práticas de saúde desenvolvidas pelos enfermeiros no cotidiano da APS, parece ser dificultada ainda mais pela falta de um plano estratégico municipal de atendimento aos usuários. Esse planejamento seria de extrema importância também para organizar o fluxo da população pelos pontos de atenção do sistema de saúde e facilitar seu acesso precoce aos serviços, principalmente em períodos epidêmicos.

Durante as entrevistas, a assistência dos casos de Dengue nas Unidades Básicas de Saúde foi representada como trama de um cenário de guerra. As principais dificuldades observadas nos relatos foram relacionadas à inadequação da área física e à insuficiência de equipamentos e de recursos materiais para atender de forma satisfatória a grande clientela com Dengue acolhida nas UBS em 2015.

No entanto, essa realidade não difere do constatado nos municípios de médio e de grande porte populacionais brasileiros. Pimenta (2015b) expõe que o desafio atual para os sistemas de saúde municipais é, de fato, aperfeiçoar o modelo assistencial de modo a priorizar as ações preventivas e a ordená-las pela APS. No Município de Alfenas, como em outras localidades, os profissionais fazem "malabarismo" para tentar equilibrar a atenção programada e a demanda espontânea por meio da instituição de uma agenda semanal e mensal de atendimento.

Segundo Pimenta (2015b, p. 384), o cenário de descompasso entre demanda e capacidade de atendimento é agravado "nos períodos de maior transmissão de Dengue, nos quais a rotina das unidades é completamente alterada". A autora lembra que "dependendo do número de casos, quase todas as outras atividades da 
demanda programada são reduzidas". Em Alfenas (EMERGENTE, 2016), o secretário de saúde anunciou um plano recente que define as Unidades Básicas de Saúde como "porta de entrada" para os usuários com suspeita de Dengue. Só não se teve notícia até então de algum projeto de reestruturação e de qualificação da APS.

Já no que se refere às estratégias de prevenção dos casos de Dengue, a Secretaria de Saúde anunciou em janeiro de 2016 um plano de intensificação das ações no combate aos focos do Aedes aegypti. A proposta foi de visitar todos os imóveis do Município em uma força-tarefa que reuniu 32 ACEs e 110 ACSs. Pensando na contenção da proliferação do mosquito vetor, a iniciativa contemplou um trabalho de orientação aos moradores a fim de prevenir e de identificar possíveis focos (EMERGENTE, 2016).

Além dessa intervenção pontual, um Comitê de Enfrentamento da Dengue foi montado com a participação de diversos setores da prefeitura para definir estratégias locais. Como a intenção é de que as ações não se restrinjam às iniciativas da Secretaria de Saúde, o comitê terá representantes da ProcuradoriaGeral do Município, bem como de outras secretarias como a do Meio Ambiente, a de Obras e a da Educação. Segundo Emergente (2016), o secretário de saúde planejou ouvir ainda ideias advindas do setor imobiliário e convidou o Ministério Público a participar das discussões. Com essa aproximação intersetorial, esperam-se medidas para o enfrentamento de situações problema, como por exemplo, a da recorrente resistência comunitária à visita domiciliar no Município.

Contudo, pensando no grau de compartilhamento das ideias pelo campo social estudado, é possível finalizar considerando que - apesar do que tem sido desenvolvido na escala municipal de Alfenas - a Dengue e seu enfrentamento foram socialmente representados pelos Enfermeiros da APS, principalmente como um problema de saúde pública, cujo controle é dificultado pela falta de conscientização da população e facilitado pelo trabalho de orientação/conscientização e pelas parcerias. 


\section{CONCLUSÕES E CONSIDERAÇÕES FINAIS}

O conhecimento sobre as Representações Sociais sobre a Dengue é importante para a compreensão da sua causalidade e para o enfrentamento do problema de Saúde Pública/Saúde Coletiva na atualidade. O referencial teóricometodológico adotado neste trabalho possibilitou ter acesso aos significados da Dengue, tendo como informantes os Enfermeiros que atuam na Atenção Primária, cujo conteúdo pode ser classificado como fator dificultador ou facilitador em relação ao desenvolvimento dos programas e das ações de enfrentamento da epidemia junto à população do município de Alfenas-MG.

O estudo, usando a Técnica do Discurso do Sujeito Coletivo, identificou significados da Dengue, que puderam ser representados pelas seguintes expressões: desconforto enorme; problema de saúde pública; descuido das pessoas; consequência da falta de educação; doença viral; preocupação e medo; doença grave; doença causada pela picada do mosquito; epidemia; doença de país pobre; mais uma doença pra gente cuidar e uma guerra. Em relação ao controle da Dengue, foram reconhecidos como dificultadores: a falta de conscientização da população; a resistência e falta de responsabilidade das pessoas; a alta proliferação do mosquito; a grande quantidade de foco; os boatos; a falta de informação sobre a doença em si; o desconhecimento da causa; a capacitação dos ACE e a falta de mais cobrança dos ACS; como facilitadores, o trabalho de orientação e de conscientização; a educação da população; a consciência das pessoas; o saneamento básico; as parcerias da ESF com os ACE; a cobrança da população; a capacitação e a remuneração dos ACE e o dever da população. Esses achados simbólicos e figurativos estão presentes no cotidiano da Atenção Primária à Saúde e evidenciam o quão polissêmica é a questão da Dengue e o quão multifacetadas são as forças que impactam no seu controle.

Ao analisar este e outros estudos desenvolvidos sobre o pensamento coletivo e social sobre as causas, sobre os facilitadores e os dificultadores para o controle da Dengue, nota-se, no imaginário dos leigos e dos profissionais, que a Dengue tem um significado bastante influenciado por uma visão determinista, focada no indivíduo, a quem se tem atribuído a responsabilidade pelo insucesso do enfrentamento da doença em nível local. A culpabilidade da população pelo descontrole da epidemia representa, na verdade, um distanciamento da visão de causalidade da doença do 
modelo multifatorial, pois a existência de reservatórios da doença no ambiente urbano também é resultado da falta de políticas de promoção de meio ambiente saudável, que vai além da atuação individual, peridomiciliar. Faz-se necessário repensar o processo saúde-doença da Dengue sob a perspectiva do Modelo de Campo de Saúde, representando a Dengue como um problema de saúde coletiva, que demanda a integração das diversas secretarias da Administração Pública, do Ministério Público e do Setor Privado, e não somente a Vigilância Epidemiológica, para empreender uma atuação continuada e completa. A culpabilização da vítima/população deve ser substituída por estratégias multiprofissionais, que se ocupem da mudança de comportamento frente aos dificultadores do controle da Dengue.

Finalmente, o estudo foi capaz de fazer emergir valores e símbolos relacionados à Dengue e ao enfrentamento da epidemia, que contribuíam com a inteligência dos serviços de saúde, mesmo que o universo de informantes tenha sido limitado aos Enfermeiros, pois estes são profissionais que atuam na Atenção Primária à Saúde do município de Alfenas-MG, promovendo o enfrentamento da Dengue. 


\section{REFERÊNCIAS}

ABRIC, J. C. A abordagem estrutural das representações sociais. In: MOREIRA, A. S. P.; OLIVEIRA, D. C. (Org.). Estudos interdisciplinares de representação social. 2. ed. Goiânia: AB, 2000. p. 27-37.

AGUIAR, W. M. J. de. Psicologia social e processo educacional - implicações ideológicas e éticas. In: JACÓ-VILELA, A. M.; SATO, L. (Org.). Diálogos em psicologia social [online]. Rio de Janeiro: Centro Edelstein de Pesquisas Sociais, 2012. p. 58-70.

ALEXANDRE, M. Representação social: uma genealogia do conceito. Comum., Rio de Janeiro, v. 10, n. 23, p. 122-138, jul./dez. 2004.

ALFENAS. Secretaria Municipal de Saúde de Alfenas. Dengue. Informe Epidemiológico. 05 nov. 2015. Alfenas, 2015.

ASSOCIAÇÃO BRASILEIRA DE NORMAS TÉCNICAS. NBR 14724: informação e documentação - apresentação. Rio de Janeiro, 2011.

BARRETO, M. L.; TEIXEIRA, M. G. Dengue no Brasil: situação epidemiológica e contribuições para uma agenda de pesquisa. Estud. av., São Paulo, v. 22, n. 64, p. 53-72, dez. 2008.

BHATT, S. et al. The global distribution and burden of Dengue. Nature (Lond.)., v. 496, p. 504-507, 25 April 2013.

BONITA, R. Epidemiologia básica. 2. ed. São Paulo, Santos. 2010. 213 p.

BRASIL. Ministério da Saúde. Programa Nacional de Controle da Dengue. Brasília: Ministério da Saúde, 2002a. . Informe da Atenção Básica. Atuação do Enfermeiro na Atenção Básica. n. 16. ano III, abr. 2002b. 2 p.

. Ministério da Saúde. Secretaria de Vigilância em Saúde. Diretoria Técnica de Gestão. Diagnóstico rápido nos municípios para vigilância entomológica do Aedes aegypti no Brasil - LIRAa: metodologia para avaliação dos índices de Breteau e Predial. Brasília: Ministério da Saúde, 2005a. 60 p. (Série A. Normas e Manuais Técnicos).

. Ministério da Saúde. Secretaria de Vigilância em Saúde. Guia de vigilância epidemiológica. 6. ed. Brasília: Ministério da Saúde, 2005b. 816 p. 
. Ministério da Saúde. Portaria no 399. Divulga o Pacto pela Saúde 2006 Consolidação do SUS e aprova as Diretrizes Operacionais do Referido Pacto. Diário Oficial da União, Brasília, DF, 23 fev. 2006a. Seção 1, p. 43-51.

. Ministério da Saúde. Secretaria-Executiva. Coordenação de Apoio à Gestão Descentralizada. Diretrizes operacionais para os pactos pela vida, em defesa do SUS e de gestão. Brasília: Ministério da Saúde, 2006b. 72 p. (Série A. Normas e Manuais Técnicos).

. Conselho Nacional de Secretários de Saúde. Vigilância em Saúde. Brasília: CONASS, 2007a. 278 p. (Coleção Progestores - Para entender a gestão do SUS, v. 6, tomo I).

. Ministério da Saúde. Secretaria de Vigilância em Saúde. Dengue: diagnóstico e manejo clínico. 3. ed. Brasília, 2007b. 28 p. (Série A. Normas e Manuais Técnicos). ISBN 978-85-334-1428-0.

. Ministério da Saúde. Secretaria de Vigilância em Saúde. Secretaria de Gestão do Trabalho e Educação na Saúde. Dengue: decifra-me ou devoro-te. Brasília, 2007c. 24 p. (Série A. Normas e Manuais Técnicos). ISBN 978-85--3341414-3.

Ministério da Saúde. Secretaria de Vigilância em Saúde. Departamento de Vigilância Epidemiológica. Diretrizes nacionais para prevenção e controle de epidemias de Dengue. Brasília: Ministério da Saúde, 2009a. 160 p. (Série A. Normas e Manuais Técnicos).

. Ministério da Saúde. O Papel da Atenção Básica no Controle da Dengue. Informe da Atenção Básica, n. 50, ano IX, jan./fev. 2009b. ISSN 18061192.

. Ministério da Saúde. Secretaria de Vigilância à Saúde. Secretaria de Atenção à Saúde. Diretrizes Nacionais da Vigilância em Saúde. Brasília: Ministério da Saúde, 2010. 108 p. (Série F. Comunicação e Educação em Saúde) (Série Pactos pela Saúde 2006; v. 13).

Conselho Nacional de Secretários de Saúde. Vigilância em Saúde. Brasília: CONASS, 2011a. 113 p. (Coleção Para Entender a Gestão do SUS 2011, 6, II).

Conselho Nacional de Secretários de Saúde. Sistema Único de Saúde. Brasília: CONASS, 2011b. 291 p. (Coleção Para Entender a Gestão do SUS 2011, 1). 
Decreto n. 7508, de 28 de julho de 2011. Regulamenta a Lei no 8.080, de 19 de setembro de 1990, para dispor sobre a organização do Sistema Único de Saúde - SUS, o planejamento da saúde, a assistência à saúde e a articulação interfederativa, e dá outras providências [Internet]. Brasília; 2011c [citado 2013 mar. 14]. Disponível em: <http://www.planalto.gov.br/ccivil_03/_ato20112014/2011/decreto/D7508.htm>. Acesso em: 29 maio 2014.

. Ministério da Saúde. Portaria no 2.760, de 19 de novembro de 2013. Autoriza repasse no Piso Variável de Vigilância em Saúde (PVVS) do Componente de Vigilância em Saúde de incentivo financeiro para qualificação das ações de vigilância, prevenção e controle da Dengue. Disponível em:

<http://bvsms.saude.gov.br/bvs/saudelegis/gm/2013/prt2760_19_11_2013.html>. Acesso em: 15 maio 2014.

Monitoramento dos casos de Dengue e febre de chikungunya até a Semana Epidemiológica 36, 2015. Boletim Epidemiológico Secretaria de Vigilância em Saúde, Ministério da Saúde, v. 46, n. 31, 2015. ISSN 2358-9450.

Ministério da Saúde. Secretaria de Atenção à Saúde. Departamento de Atenção Básica. Política Nacional de Atenção Básica. Brasília: Ministério da Saúde, 2012. 110 p. : il. - (Série E. Legislação em Saúde).

. Ministério da Saúde. Secretaria de Vigilância em Saúde. Departamento de Vigilância das Doenças Transmissíveis. Dengue: diagnóstico e manejo clínico: adulto e criança [recurso eletrônico]. 5. ed. Brasília: Ministério da Saúde, 2016. 58 p.

. Ministério da Saúde. Vigilância em Saúde: Dengue, Esquistossomose, Hanseníase, Malária, Tracoma e Tuberculose. 2. ed. rev. Brasília: Ministério da Saúde, 2008. 195 p. (Série A. Normas e Manuais Técnicos) (Cadernos de Atenção Básica, n. 21).

BRASILSUS. Descoberto novo tipo de vírus da Dengue. Out. 2013. Disponível em: <http://www.brasilsus.com.br/noticias/8-destaques/121005-descoberto-novotipo-de-virus-da-Dengue.html>. Acesso em: 21 maio 2014.

CAMPOS, G. W. de S. Saúde pública e saúde coletiva: campo e núcleo de saberes e práticas. Ciência \& Saúde Coletiva, v. 5, n. 2, p. 219-230, 2000.

CASTELLS, M. A sociedade em rede. 4. ed. São Paulo: Paz e Terra, 2000. v. I.

CASTRO, P. Notas para uma leitura das representações sociais em S. Moscovici. Análise Social, Lisboa, n. 164, v. 37, p. 949-979, 2002.

CATÃO, R. de C. Dengue no Brasil: abordagem geográfica na escala nacional. São Paulo: Cultura Acadêmica, 2012. 175 p. 
CESARINO, M. B. et al. A difícil interface controle de vetores - atenção básica: inserção dos agentes de controle de vetores da Dengue junto às equipes de saúde das unidades básicas no município de São José do Rio Preto, SP. Saude soc., São Paulo, v. 23, n. 3, p. 1018-1032, set. 2014.

CEZAR-VAZ, M. R. et al. Conhecimento clínico do enfermeiro na Atenção Primária à Saúde: aplicação de uma matriz filosófica de análise. Texto contexto - enferm., Florianópolis, v. 19, n. 1, mar. 2010.

CHIARAVALLOTI NETO, F. et al. Controle do Dengue em uma área urbana do Brasil: avaliação do impacto do Programa Saúde da Família com relação ao programa tradicional de controle. Cad. Saúde Pública, Rio de Janeiro, v. 22, n. 5, p. 987-997, maio 2006.

CONSELHO FEDERAL DE ENFERMAGEM (COFEN). Resolução COFEN 311/2007. Aprova a Reformulação do Código de Ética dos Profissionais de Enfermagem. Rio de Janeiro, 08 de fevereiro de 2007.

CONSELHO REGIONAL DE ENFERMAGEM DE MINAS GERAIS (COREN-MG). Legislação e normas. Belo Horizonte: Coren-MG, v. 13, n. 1, 2013. 86 p.

COSTA, N. R. Os Desafios Atuais da Política Pública para a Dengue. Jornal Valor Econômico, Rio de Janeiro, 24 fev. 2011. Disponível em:

<http://www.valor.com.br/arquivo/874377/os-desafios-atuais-da-politica-publica-paraDengue>. Acesso em: 20 maio 2014.

COVEY, S. R. Liderança \& Negociação. Fazendo com que as pessoas se envolvam. 11 out. 2007. Cap. 21. Disponível em:

<http://liderancaemnegociacao.blogspot.com.br/2007/10/captulo-21-fazendo-comque-as-pessoas_11.html>. Acesso em: 03 mar. 2015.

CUNHA, R. V. da.; MARTÍNEZ, E. Manejo Clínico do Paciente com Dengue. In: VALLE, D.; PIMENTA, D. N.; CUNHA, R. V. D. (Org.). Dengue: teorias e práticas. Rio de Janeiro: Fiocruz, 2015. cap. 10, p. 221-245.

DAVID, H. M. S. L.; MARTELETO, R. M. Almanaque da Dengue: leituras e narrativas de Agentes Comunitários de Saúde. Rev. bras. enferm., Brasília, v. 65, n. 6, p. 909-915, Dec. 2012.

DE ROSA, A. S. From theory to metatheory in social representations: the lines of argument of a theoretical-methodological debate. Social Science Information. v. 33, n. 2, p. 273-303, 1994,

DESCRITORES EM CIÊNCIAS DA SAÚDE (DeCS). Ação Intersetorial [internet]. São Paulo: Biblioteca virtual em saúde (BVS); [atualizado em 2015 out. 07; citado em 2015 out. 10]. Disponível em: <http://decs.bvs.br/>. 
DICK, O. B. et al. The History of Dengue Outbreaks in the Americas. Am. j. trop. med. hyg, v. 87, n. 4, p. 584-593, 2012.

DURKHEIM, E. O suicídio: estudo de Sociologia. São Paulo: Martins Fontes, 2000.

EMERGENTE, A. Situação de alerta preocupa Secretaria de Saúde que intensifica combate à Dengue. Alfenas Hoje. 12 de janeiro de 2016. Disponível em:

$<$ http://www.alfenashoje.com.br/noticia.asp?id_noticia=11092>. Acesso em: 15 jan. 2016.

FARR, R. Representações sociais: a teoria e sua história. In: GUARESCHI, P.; JOVCHELOVITCH, S. (Org.). Textos em representações sociais. 4. ed. Petrópolis: Vozes, 1994. p. 31-59.

FIGUEIREDO, L. T. M. Patogenia das infecções pelos vírus do Dengue. Medicina, Ribeirão Preto, v. 32, p. 15-20, jan./mar. 1999.

FIGUEIREDO, M. Z. A.; CHIARI, B. M.; GOULART, B. N. G. Discurso do Sujeito Coletivo: uma breve introdução à ferramenta de pesquisa qualiquantitativa. Distúrb Comun, São Paulo, v. 25, n. 1, p. 129-136, abr. 2013. Disponível em: $<$ http://revistas.pucsp.br/index.php/dic/article/viewFile/14931/11139>. Acesso em: 13 jun 2014.

FLAUZINO, R. F.; SOUZA-SANTOS, R.; OLIVEIRA, R. M. Dengue, geoprocessamento e indicadores socioeconômicos e ambientais: um estudo de revisão. Rev Panam Salud Publica, Washington, v. 25, n. 5, p. 456-461, maio 2009.

FRACOLLI, L. A. et al . Conceito e prática da integralidade na Atenção Básica: a percepção das enfermeiras. Rev. esc. enferm. USP, São Paulo, v. 45, n. 5, out. 2011. Disponível em: <http://www.scielo.br/scielo.php?script=sci_arttext\&pid=S008062342011000500015\&lng=en\&nrm=iso >. Acesso em: 29 maio 2014.

FRANCA, E. et al. Participação da população em projeto de controle de Dengue em Belo Horizonte, Minas Gerais: uma avaliação. Inf. Epidemiol. Sus, Brasília, v. 11, n. 4, dez. 2002.

FREIRE, N. Ponto de vista com Nelson Freire. CEI Mirassol participa de campanha contra a Dengue nesta sexta-feira. O jornal de Hoje, 01 ago. 2014. Disponível em: $<$ http://www.pontodevistaonline.com.br/wp-content/uploads/2014/08/folderDengue.jpg >. Acesso em: 04 set. 2015.

FREITAS, R. M.; RODRIGUES, C. S.; ALMEIDA, M. C. M. Estratégia intersetorial para o controle da Dengue em Belo Horizonte (Minas Gerais). Brasil. Saúde Soc., v. 20, n. 3, p. 773-785, jul./set. 2011. 
GALLER, R.; BONALDO, M. C.; ALVES, A. M. de B. Desenvolvimento de Vacinas Contra Dengue. In: VALLE, D.; PIMENTA, D. N.; CUNHA, R. V. D. (Org.). Dengue: teorias e práticas. Rio de Janeiro: Fiocruz, 2015. cap. 8, p. 187-204.

GARCIA, L. M. T. et al. Intersetorialidade na saúde no Brasil no início do século XXI: um retrato das experiências. Saúde debate, v. 38, n. 103, p. 966-980, out./dez. 2014.

GUBLER, D. J. Dengue/Dengue haemorrhagic fever: history and current status. Novartis Found Symp, v. 277, p. 3-16, 2006. Disponível em: <http://www.ncbi.nlm.nih.gov/pubmed/17319151>. Acesso em: 20 maio 2014.

GUZMAN, M. G. et al. Dengue: a continuing global threat. Nat Rev Microbiol., v. 8, n. S, p. 7-16, 2010. Disponível em:

<http://www.ncbi.nlm.nih.gov/pubmed/21079655>. Acesso em: 20 maio 2014.

HALSTEAD, S. B. Dengue haemorrhagic fever, a public problem and a field for research. Bolletin of the World Health Organization, v. 58, p. 1-21, 1982.

HALSTEAD, S. B. Observations related to pathogenesis of Dengue hemorrhagic fever. VI. Hypothesis and discussion. Yale Journal of Biology and Medicine, v. 42, p. 350-360, 1970.

IBGE. CENSO 2000. Disponível em: <www.ibge.gov.br/censo/>. Acesso em: 9 maio 2015.

CIDADES@. Disponível em:

$<$ www.ibge.gov.br/cidadesat/xtras/perfil.php?codmun=310160\&search=minasgerais|alfenas>. Acesso em: 7 ago. 2013.

INOJOSA, R. M. Sinergia em políticas e serviços públicos: desenvolvimento social com intersetorialidade. Cadernos Fundap, v. 22, p. 102-110, 2001.

JARDIM, J. B.; SCHALL, V. T. Participação Social no Controle da Dengue: a importância de uma mudança conceitual. In: VALLE, D.; PIMENTA, D. N.; CUNHA, R. V. D. (Org.). Dengue: teorias e práticas. Rio de Janeiro: Fiocruz, 2015. cap. 15, p. 317-338.

JODELET, D. Loucuras e representações sociais. Petrópolis: Vozes, 2005.

Représentations sociales: un domaine en expansion. In: JODELET, D. (Ed.). Les représentations sociales. Paris: PUF, 1989. p. 31-61. Tradução: Tarso Bonilha Mazzotti. Revisão Técnica: Alda Judith Alves-Mazzotti. UFRJ- Faculdade de Educação, dez. 1993. Disponível em: <http://portal.estacio.br/media/3432753/jodeletdrs-um-dominio-em-expansao.pdf>. Acesso em: 13 jun 2014. 
JUNQUEIRA, L. A. P. Intersetorialidade, transetorialidade e redes sociais na saúde. Rev. adm. pública, v. 34, n. 6, p. 35-45, nov./dez. 2000.

KAWAMOTO, E. E. Saúde. In: KAWAMOTO, E. E.; SANTOS, M. C. H.; MATTOS, T. M. Enfermagem comunitária. São Paulo: EPU, 1995. p. 11-21.

KOURI, G. P.; GUZMÁN, M. G.; BRAVO, J. R. Why Dengue haemorrhagic fever in Cuba? 2. An integral analysis. Trans. R. Soc. Trop. Med. Hyg, v. 81, p. 821-823, 1987.

LALONDE, M. A new perspective on the health of Canadians. Ottawa: Canadian Department of National Health and Welfare; 1974.

LAVRAS, C. Atenção Primária à Saúde e a Organização de Redes Regionais de Atenção à Saúde no Brasil. Saude soc., São Paulo, v. 20, n. 4, dez. 2011.

LEFEVRE, A. M. C. et al.. Representações sobre Dengue, seu vetor e ações de controle por moradores do município de São Sebastião, litoral Norte do Estado de São Paulo, Brasil. Cad. Saúde Pública, Rio de Janeiro, v. 23, n. 7, Jul. 2007.

LEFEVRE, F. et al. Representações sociais sobre relações entre vasos de plantas e o vetor da Dengue. Rev. saúde pública, v. 38, n. 3, p. 405-414, 2004.

; LEFEVRE, A. M. C. Depoimentos e Discursos: uma proposta de análise em pesquisa social. Brasília: Liber Livro Editora, 2005. v. 12. 97 p. (Série Pesquisa).

; LEFEVRE, A. M. C. O discurso do sujeito coletivo: um novo enfoque em pesquisa qualitativa. Caxias do Sul: Educs; 2003a.

; LEFEVRE, A. M. C. Pesquisa de Representação Social: um enfoque qualiquantitativo: a metodologia do discurso do sujeito coletivo. 2. ed. Brasília: Liber Livro Editora, 2012. 224 p.

; LEFEVRE A. M. C. Pesquisa qualitativa levada a sério. 2003b.

[internet]. Disponível em: <http://www.fsp.usp.br/ flefevre/Discurso_o_que_e.htm>. Acesso em: 12 maio 2015.

LEITE, R. F. B.; VELOSO, T. M. G. Trabalho em equipe: representações sociais de profissionais do PSF. Psicol. cienc. prof., Brasília, v. 28, n. 2, p. 374-389, 2008. Disponível em: <http://www.scielo.br/scielo.php?script=sci_arttext\&pid=S141498932008000200012\&lng=en\&nrm=iso >. Acesso em: 11 maio 2015.

LIMA, R. S. Gerenciamento em enfermagem no contexto hospitalar: o discurso do enfermeiro e sua equipe. 2013. 231 f. Dissertação (Mestrado em Enfermagem) Escola de Enfermagem, Universidade Federal de Alfenas, Alfenas, 2013. 
MATOS, E.; PIRES, D. E. P. de. Práticas de cuidado na perspectiva interdisciplinar: um caminho promissor. Texto contexto - enferm., Florianópolis, v. 18, n. 2, jun. 2009. Disponível em: <http://www.scielo.br/scielo.php?script=sci_arttext\&pid=S010407072009000200018\&lng=en\&nrm=iso >. Acesso em: 29 maio $2 \overline{0} 14$.

McARTHUR, M. A.; SZTEIN, M. B.; EDELMAN, R. Dengue vaccines: recent developments, ongoing challenges and current candidates. Expert Rev. Vaccines, v. 12, p. 933-953, 2013.

McMICHAEL, A. J. et al. Climate change and human health, risks and responses. Geneva: World Health Organization, 2003.

MENDES, E. V. As Redes de Atenção à Saúde. Brasília: Organização PanAmericana da Saúde, 2011. 549 p.

MINAYO, M. C. S. O Desafio do Conhecimento: pesquisa qualitativa em saúde. 12. ed. São Paulo: Hucitec, 2010. 407 p.

MOSCOVICI, S. A representação social da psicanálise. Rio de Janeiro: Zahar, 1978.

Representações sociais: investigações em psicologia social. P. A. Guareschi, trad. 2. ed. Petrópolis, RJ: Vozes, 2004.

MURRAY, N. E.; QUAM, M. B.; WILDER-SMITH, A. Epidemiology of Dengue: past, present and future prospects. Clinical Epidemiology, v. 5, p. 299-309, 2013.

Disponível em: <http://www.ncbi.nlm.nih.gov/pmc/articles/PMC3753061/>. Acesso em: 20 maio 2014.

MUSTAFA, M. S. et al. Discovery of fifth serotype of Dengue virus (DENV-5): A new public health dilemma in Dengue control. Med J Armed Forces India, v. 71, n. 1, p. 67-70, jan. 2015. doi: 10.1016/j.mjafi.2014.09.011. Epub 2014 Nov 24.

NASCIMENTO, M. C. Geoepidemiologia da Dengue no município de Alfenas, MG. 2011. 70 f. Dissertação (Mestrado em Saúde na Comunidade) - Faculdade de Medicina de Ribeirão Preto, Universidade de São Paulo, Ribeirão Preto, 2011a.

; RODRIGUES-JUNIOR, A. L. Geoepidemiologia da Dengue em AlfenasMG: Densidade Espacial de Casos e Estratégia Saúde da Família. In: SIMPÓSIO NACIONAL DE GEOGRAFIA DA SAÚDE, 5. e FÓRUM INTERNACIONAL DE GEOGRAFIA DA SAÚDE, 2., 2011, Recife. Resumos... Recife: IMIP - Instituto de Medicina Integral Professor Fernando Figueira, 2011.

; RODRIGUES-JÚNIOR, A. L. Análisis espacial del Dengue y la atención primaria de salud en Alfenas, Minas Gerais, Brasil. Atención Primaria (Barcelona. Ed. impresa) JCR, v. 46, p. 449-451, 2014. 
; RODRIGUES-JÚNIOR, A. L.; RODRIGUES, D. O. Configuração

Espacial da Dengue no Contexto Socioeconômico de Alfenas-MG: Retrato de uma Década. Medicina (USP.FMRP), v. 48, p. 181-189, 2015.

NASCIMENTO, S. Reflexões sobre a intersetorialidade entre as políticas públicas.

Serv. Soc. Soc., n. 101, p. 95-120, jan./mar. 2010.

NELSON, R. Neglected tropical diseases take hold in the USA. The Lancet Infectious Diseases, v. 14, n. 11, p. 1050-1051, November 2014. Disponível em: <http://www.thelancet.com/journals/laninf/article/PIIS1473-3099(14)70795-9/fulltext>. Acesso em: 10 jul 2015.

OLIVEIRA, F. O. de.; WERBA, G. C. Representações Sociais. In: JACQUES, M. G. C. et al. Psicologia Social Contemporânea: livro-texto. 18. ed. Petrópolis: Vozes, 2012. $262 \mathrm{p}$.

OLIVEIRA, G. L. A. Prevenção e controle da Dengue no município de

Sabará/MG: análise de materiais educativos impressos e das representações sociais de agentes de controle de endemias. 2012. 183 f. Dissertação (Mestrado em Ciências da Saúde) - Centro de Pesquisas René Rachou. Fundação Oswaldo Cruz Belo Horizonte (MG) 2012.

OLIVEIRA, R. L. de. Biologia e Comportamento do Vetor. In: VALLE, D.; PIMENTA, D. N.; CUNHA, R. V. D. (Org.). Dengue: teorias e práticas. Rio de Janeiro: Fiocruz, 2015a. cap. 3, p. 75-92.

OLIVEIRA, R. L. de. Transmissão Vetorial. In: VALLE, D.; PIMENTA, D. N.; CUNHA, R. V. D. (Org.). Dengue: teorias e práticas. Rio de Janeiro: Fiocruz, 2015b. cap. 5, p. 127-146.

OLIVEIRA, R. M. de. A Dengue no Rio de Janeiro: repensando a participação popular em saúde. Cad. Saúde Pública, Rio de Janeiro, v. 14, supl. 2, p. S69-S78, 1998

OPAS. OMS. BRASIL. Diretrizes Nacionais para a Prevenção e Controle de Epidemias de Dengue. Disponível em:

<http://www.paho.org/bra/index.php?option=com_content\&view=article\&id=599>. Acesso em: 06 ago. 2009.

ORGANIZAÇÃO MUNDIAL DA SAÚDE (OMS). Fundo das Nações Unidas para a Infância (UNICEF). Alma-Ata 1978. Relatório da Conferência Internacional sobre Cuidados Primários de Saúde. Brasília, 1979. 64 p.

ORGANIZACIÓN PANAMERICANA DE LA SALUD (OPS). Guías de atención para enfermos de Dengue en la región de las Américas. La Paz: OPS, OMS, 2010. 
PARANÁ. Secretaria da Saúde do Estado do Paraná. Dengue - Características clínicas e epidemiológicas. Disponível em:

$<$ http://www.Dengue.pr.gov.br/modules/conteudo/conteudo.php?conteudo=11>.

Acesso em: 23 nov. 2015.

PATOLOGIA DE FEBRES HEMORRÁGICAS FMUSP. Dengue. Disponível em: $<$ http://www2.fm.usp.br/pfh/mostrahp2.php?origem=pfh\&xcod=Dengue\&dequem=Pri ncipal>. Acesso em: 10 jul 2015.

PENNA, M. L. F. Um desafio para a saúde pública brasileira: o controle do Dengue. Cad. Saúde Pública, Rio de Janeiro, v. 19, n. 1, p. 305-309, fev. 2003. Disponível em: <http://www.scielo.br/scielo.php?script=sci_arttext\&pid=S0102311X2003000100034\&Ing=en\&nrm=iso >. Acesso em: 21 out. 2015.

PEREIRA, I. C.; OLIVEIRA, M. A. C. Atenção Primária, promoção da saúde e o Sistema Único de Saúde: um diálogo necessário. São Paulo: Escola de Enfermagem da Universidade de São Paulo, 2014. 109 p.

PESSANHA, J. E. M. et al. Avaliação do Plano Nacional de Controle da Dengue.

Cad. Saúde Pública, Rio de Janeiro, v. 25, n. 7, jul. 2009. Disponível em: <http://www.scielo.br/scielo.php?script=sci_arttext\&pid=S0102-

311X2009000700024\&lng=en\&nrm=iso>. Acesso: 21 maio 2014.

PIMENTA JÚNIOR, F. G. Gestão e Planejamento na Prevenção e no Controle da Dengue. In: VALLE, D.; PIMENTA, D. N.; CUNHA, R. V. D. (Org.). Dengue: teorias e práticas. Rio de Janeiro: Fiocruz, 2015. cap. 18, p. 381-405.

PIMENTA, D. F. A (Des)Construção da Dengue: de tropical a negligenciada. In: VALLE, D.; PIMENTA, D. N.; CUNHA, R. V. D. (Org.). Dengue: teorias e práticas. Rio de Janeiro: Fiocruz, 2015a. cap. 1, p. 23-59.

PIMENTA, N. F. Determinação Social, Determinantes Sociais da Saúde e a Dengue: caminhos possíveis? In: VALLE, D.; PIMENTA, D. N.; CUNHA, R. V. D. (Org.). Dengue: teorias e práticas. Rio de Janeiro: Fiocruz, 2015b. cap. 19, p. 407-447.

REIS, C. B.; ANDRADE, S. M. O.; CUNHA, R. V. Aliados do A. Aegypti: fatores contribuintes para a ocorrência do Dengue segundo as representações sociais dos profissionais das equipes de saúde da família. Ciênc. saúde coletiva, v. 18, n. 2, p. 517-526, 2013.

REIS, S. L. A.; BELLINI, M. Representações Sociais: Teoria, Procedimentos Metodológicos e Educação Ambiental. Acta Scientiarum. Human and Social Sciences., Maringá, v. 33, n. 2, p. 149-159, 2011.

REZENDE, J. M. de. Epidemia, Endemia, Pandemia. Epidemiologia. Revista de patologia tropical, v. 27, n. 1, p. 153-155, jan./jun. 1998. 
RIBEIRO, A. F. Crença, responsabilidade e comunicação sobre a Dengue em Aparecida, SP: um estudo de representações sociais. 2008. 129 f. Dissertação (Mestrado em Saúde Pública). Faculdade de Saúde Pública, Universidade de São Paulo, São Paulo (SP): 2008.

RODRIGUES, D. O. Coordenador de Vigilância em Saúde de Alfenas. Conversa informal e/ou entrevista. 2015.

RODRIGUES-JUNIOR, A. L. Inteligência Epidemiológica. In: GALVAO, M. C. B.; RICARTE, I. L. M. Prontuário do Paciente. Rio de Janeiro: Guanabara Koogan, 2012. $344 \mathrm{p}$.

ROSEN, L. The emperor's new clothes revised, or reflections on the pathogenesis of Dengue haemorrhagic fever. American Journal of Tropical Medicine and Hygiene, v. 26, p. 337-343, 1977.

SCHAFFNER, F.; FONTENILLE, D.; MATHIS, A. Autochthonous Dengue emphasises the threat of arbovirosis in Europe. The Lancet Infectious Diseases, $v$. 14, n. 11, p. 1044, November 2014. Disponível em:

<http://www.thelancet.com/journals/laninf/article/PIIS1473-3099(14)70925-9/fulltext>. Acesso em: 21 dez. 2015.

; MATHIS, A. Dengue and Dengue vectors in the WHO European region: past, present, and scenarios for the future. The Lancet Infectious Diseases, v. 14, n. 12, p. 1271-1280, December 2014. Disponível em: <http://www.thelancet.com/journals/laninf/article/PIIS1473-3099(14)708345/abstract>. Acesso em: $21 \mathrm{dez} .2015$.

SCHATZMAYR, H.G. Aspectos históricos da Dengue e de seus vetores. In: Dengue e diagnóstico, tratamento e prevenção. Rio de Janeiro, Rubio, 2007. p. 1-10.

SCHWEICKARDT, J. C. Ciência, Nação e Região: as doenças tropicais e o saneamento no estado do Amazonas, 1890-1930. Rio de Janeiro: Fiocruz, 2011. 344 p.

SECRETARIA DE ESTADO DE SAÚDE DE MINAS GERAIS (SES-MG) 2015. Disponível em: <http://saude.mg.gov.br/component/gmg/story/7795-informeepidemiologico-da-Dengue-09-12-2015>. Acesso em: 21 dez. 2015.

SILVA, J. V. da. Os significados de espiritualidade e religiosidade: as representações sociais de segmentos populacionais de cidades sul-mineiras. 2012. 310 f. Tese (Pós-Doutorado) - Faculdade de Medicina, Universidade de São Paulo, São Paulo, 2012.

SOCIEDADE BRASILEIRA DE MEDICINA TROPICAL (SBMT). Dengue tipo 5 é descoberta em país tropical. Nov. 2013. Disponível em: <http://www.sbmt.org.br/site/corpo_texto/2557>. Acesso em: 22 maio 2014. 
SOUZA, L. E. P. F. de. Saúde Pública ou Saúde Coletiva? Revista Espaço para a Saúde, Londrina, v. 15, n. 4, p. 01-21, out./dez. 2014.

SOUZA, R. V. de; HOTTZ, E. D. Aspectos Clínicos da Dengue: patogenia. In: VALLE, D.; PIMENTA, D. N.; CUNHA, R. V. D. (Org.). Dengue: teorias e práticas. Rio de Janeiro: Fiocruz, 2015. cap. 11, p. 247-264.

SPINK, M. J. P. O conceito de representação social na abordagem psicossocial. Cad. Saúde Pública, Rio de Janeiro, v. 9, n. 3, p. 300-308, set. 1993. Disponível em: <http://www.scielo.br/scielo.php?script=sci_arttext\&pid=S0102311X1993000300017\&Ing=en\&nrm=iso>. Acesso em: 18 maio 2015.

STAHL, H.C.; BUTENSCHOEN, V. M.; TRAN, H. T. et al. Cost of Dengue outbreaks: literature review and country case studies. BMC public health (Online), v. 13, p. 1048, 2013.

STARFIELD, B. Atenção Primária: equilíbrio entre necessidades de saúde, serviços e tecnologia. Brasília: UNESCO, Ministério da Saúde, 2002. 726p.

TAPIA-CONYER, R.; BETANCOURT-CRAVIOTO, M.; MENDEZ-GALVAN, J. Dengue: an escalating public health problem in Latin America. Paediatr Int Child Health, v. 32, Suppl 114-17, 2012. Disponível em: <http://www.ncbi.nlm.nih.gov/pubmed/22668444>. Acesso em: 21 maio 2014.

TAUIL, P. L. Aspectos críticos do controle do Dengue no Brasil. Cad. Saúde Pública, Rio de Janeiro, v. 18, n. 3, p. 867-871, jun. 2002. Urbanização e ecologia do Dengue. Cad. Saúde Pública, Rio de Janeiro, v. 17, supl. S99-S102, 2001.

TEIXEIRA, L. A. Da transmissão hídrica a culicidiana: a febre amarela na sociedade de medicina e cirurgia de São Paulo. Revista Brasileira de História, v. 21, n. 41, p. 217-242, 2001 Associação Nacional de História. São Paulo, Brasil.

TEIXEIRA, M. da G. et al. Avaliação de impacto de ações de combate ao Aedes aegypti na cidade de Salvador, Bahia. Rev. bras. epidemiol., São Paulo, v. 5, n. 1, abr. 2002. Disponível em:

<http://www.scielo.br/scielo.php?script=sci_arttext\&pid=S1415-

790X2002000100012\&Ing=en\&nrm=iso >. Acesso em: 27 maio 2014.

TEIXEIRA, M. da G.; COSTA, M. C. N.; BARRETO, M. L.; BARRETO, F. R. Epidemiologia da Dengue. In: VALLE, D.; PIMENTA, D. N.; CUNHA, R. V. D. (orgs.). Dengue: teorias e práticas. Rio de Janeiro: Fiocruz, 2015. cap. 14, p. 293-315.

TEIXEIRA, M. G.; BARRETO, M. L. Porque devemos, de novo, erradicar o Aedes aegypti. Ciência \& Saúde Coletiva, v. 1, p. 122-35, 1996. 
THE LANCET INFECTIOUS DISEASES. Editorial. Neglected tropical diseases: no longer someone else's problem. The Lancet Infectious Diseases, v. 14, n. 10, p. 899, October 2014. Disponível em:

<http://www.thelancet.com/journals/laninf/article/PIIS1473-3099(14)70928-4/fulltext>. Acesso em: 15 fev. 2015.

THOMAS, S. J. Preventing Dengue - Is the Possibility Now a Reality? N. Engl. j. med., v. 372, p. 172-173, 8 jan. 2015.

TORRES, E. M. Dengue. Rio de Janeiro: Fiocruz, 2005. 344 p.

VALA, J. Representações Sociais e Psicologia Social do Conhecimento Cotidiano. In: VALA, J.; MONTEIRO, M. B. (Coord.). Psicologia Social. 6. ed. Lisboa: Fundação Calouste Gulbenkian, 2004. 625 p.

VALERIO, L. et al. Arboviral infections diagnosed in a European area colonized by Aedes albopictus (2009-2013, Catalonia, Spain). Travel Medicine and Infectious Disease, v. 13, Issue 5, p. 415-421, September-October 2015. Disponível em: <http://www.travelmedicinejournal.com/article/S1477-8939(15)00109-X/fulltext>. Acesso em: 13 jan. 2016

VALLA, V. V. Participação popular e saúde: a questão da capacitação técnica no Brasil. In: VALLA, V. V. \& STOTZ, E. N. (Org.). Participação Popular, Educação e Saúde: Teoria e Prática. Rio de Janeiro: Relume-Dumará, 1993. p. 55-86.

OLIVEIRA, M. A. de C.; PEREIRA, I. C. Atributos essenciais da Atenção Primária e a Estratégia Saúde da Família. Rev. bras. enferm., Brasília, v. 66, n. spe, p. 158-164, set. 2013.

VILLELA, E. F. M.; ALMEIDA, M. A. Representações sociais sobre Dengue: reflexões sobre a mediação da informação em saúde pública. Saúde Soc., v. 22, n. 1, p. 124-137, 2013.

; NATAL, D. Mídia, saúde e poder: um jogo de representações sobre Dengue. Saúde Soc., v. 23, n. 3, p. 1007-1017, 2014.

WORLD HEALTH ORGANIZATION (WHO). Handbook for clinical management of Dengue. Geneva: WHO, 2012.

Sustaining the drive to overcome the global impact of neglected tropical diseases: second WHO report on neglected diseases. Geneva: WHO, 2013. $140 \mathrm{p}$.

. Dengue: guidelines for diagnosis, treatment, prevention and control.

New edition, 2009. Disponível em:

$<$ http://www.who.int/tdr/publications/documents/Dengue-diagnosis.pdf>. Acesso em: 04 set. 2015. 
Report of the Consultation on Key Issues in Dengue Vector Control Toward the Operationalization of a Global Strategy: WHO, Geneva, 6-10 June 1995. Editora World Health Organization, 1995. 48 p.

XAVIER, A. L. R. et al. Manifestações clínicas na Dengue: diagnóstico laboratorial. J. bras. med, v. 102, n. 2, p. 7-14, mar.-abr. 2014. 


\section{APÊNDICE A - Formulário de Entrevista}

\section{FORMULÁRIO DE ENTREVISTA}

\section{Dados cadastrais}

Código do áudio: Data da entrevista:

Sigla de referência: Idade: Sexo: ( ) Masc ( ) Fem

Tempo de serviço: O entrevistado já teve Dengue? ( ) Sim ( ) Não

\section{Questões abertas para o profissional de saúde}

1. Se uma amiga Ihe perguntasse o que a Dengue significa para você, qual seria a sua resposta?

Objetivo: Conhecer o que a Dengue significa para os Enfermeiros da Atenção Primária à Saúde (APS).

2. Se essa mesma pessoa lhe perguntasse ainda: "Para você, o que dificulta o controle da Dengue?" O que você Ihe diria?

Objetivo: Identificar dificuldades (forças retratoras) para o controle da Dengue, segundo a ótica dos Enfermeiros da APS.

3. Para você, o que facilita o controle da Dengue? Objetivo: Identificar facilidades (forças propulsoras) para o controle da doença, pelo prisma dos atores sociais abordados.

\section{Observações / Anotações}




\section{APÊNDICE B - Solicitação de Autorização da Pesquisa}
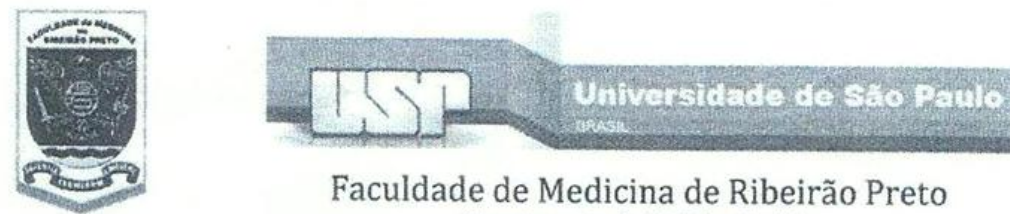

Faculdade de Medicina de Ribeirão Preto

Departamento de Medicina Social

\section{SOLICITAÇÃO DE AUTORIZAÇÃO PARA PESQUISA NO MUNICÍPIO}

Alfenas, 20 de Junho de 2013

\section{A Sua Senhoria o Senhor Maurício Durval de Sá}

Assunto: solicitação de autorização para realização de coleta de dados para pesquisa.

Vimos, por meio desta, solicitar autorização para realização da coleta de dados para a pesquisa intitulada "Representações Sociais de Enfermeiros da Atenção Primária à Saúde sobre a Dengue em Alfenas-MG", a ser desenvolvida pelo Prof. Me. Murilo César do Nascimento, sob a orientação do Prof. Dr. Antônio Luiz Rodrigues Júnior, do Departamento de Medicina Social da Faculdade de Medicina de Ribeirão Preto - Universidade de São Paulo - USP. Esclarecemos que esse trabalho resultará numa tese de doutorado que tem como objetivo estudar a percepção de Enfermeiros atuantes na Atenção Primária à Saúde de Alfenas-MG sobre a Dengue no Município. $O$ motivo que nos leva a estudar o problema da Dengue é o fato desta doença continuar resistindo aos métodos tradicionais de controle e impactando nos contexto social e de saúde da população. Diante disso e considerando que o enfermeiro é um profissional historicamente identificado pelo compromisso com a saúde pública, com um perfil ativo nas atividades de prevenção, manejo do tratamento, ações de vigilância epidemiológica e controle das doenças, é que esta pesquisa se justifica. Acredita-se que o enfermeiro pode ser um elemento chave no processo de aprofundamento do conhecimento sobre a Dengue no nível local.

Trata-se, portanto, de uma Pesquisa Social em Saúde, de abordagem qualiquantitativa, que terá como Referencial Teórico-Metodológico a Teoria das Representações Sociais (TRS). Serão realizadas entrevistas a 18 profissionais, que correspondem ao total de enfermeiros na Atenção Primária da cidade, com aplicação de um formulário para coleta de dados cadastrais e dos depoimentos resultantes de cinco perguntas abertas sobre o problema de pesquisa. A abordagem será feita nas Unidades Básicas de Saúde, onde os convidados primeiramente serão orientados sobre o objetivo do trabalho e informados sobre os direitos e condições a eles assegurados durante todas as etapas do estudo. Os discursos individuais (registrados com gravadores de áudio) serão posteriormente analisados por meio da Técnica do Discurso do Sujeito Coletivo (DSC). Para apresentação dos resultados, discussão e considerações finais, utilizar-se-á a Teoria Hermenêutica como Referencial Interpretativo. Reafirmamos, por fim, nosso compromisso de fornecer como contrapartida, um retorno sobre os resultados, por meio de apresentação pública aos representantes da Secretaria Municipal de Saúde de Alfenas.

\section{Atenciosamente,}

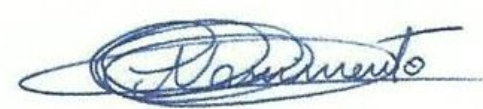

Prof. Me. Murilo César do Nascimento Doutorando em Saúde na Comunidade Universidade de São Paulo - USP Faculdade de Medicina de Ribeirão Preto Departamento de Medicina Social

Contatos: (35) 9163-2720 / murilocesar2003@yahoo.com.br

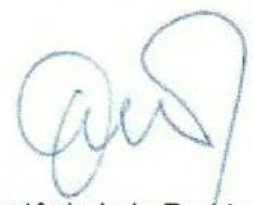

Prof. Dr. Antônio Luiz Rodrigues Júnior Universidade de São Paulo - USP Faculdade de Medicina de Riberăão Preto Departamento de Medicina Social Laboratório de Geoepidemiologia Contato: (16) 3602-2537 / alj@@fmrp.usp.br

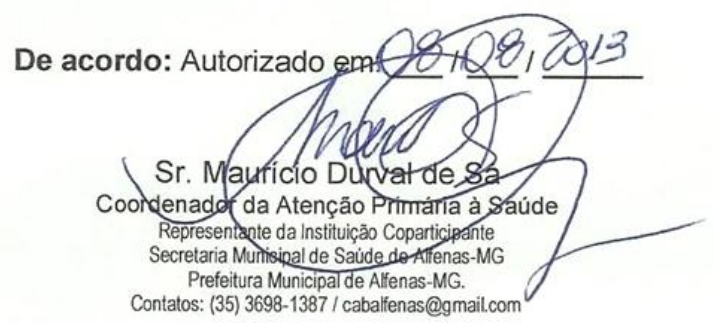




\section{APÊNDICE C - Termo de Consentimento Livre e Esclarecido}

\section{TERMO DE CONSENTIMENTO LIVRE E ESCLARECIDO}

Você está sendo convidado(a) como voluntário(a) a participar da pesquisa: REPRESENTAÇÕES SOCIAIS DE ENFERMEIROS DA ATENÇÃO PRIMÁRIA À SAÚDE SOBRE A DENGUE EM ALFENAS-MG.

A JUSTIFICATIVA, OS OBJETIVOS E OS PROCEDIMENTOS: O motivo que nos leva a estudar o problema da Dengue é o fato desta doença continuar resistindo aos métodos tradicionais de controle e impactando nos contexto social e de saúde da população. Diante disso e considerando que o enfermeiro é um profissional historicamente identificado pelo compromisso com a saúde pública, com um perfil ativo nas atividades de prevenção, manejo do tratamento, ações de vigilância epidemiológica e controle das doenças, é que esta pesquisa se justifica. Acredita-se que o enfermeiro pode ser um elemento chave no processo de aprofundamento do conhecimento sobre a Dengue no nível local. Por isso, os objetivos dessa proposta são de conhecer o que a Dengue significa para os Enfermeiros da Atenção Primária à Saúde; bem como identificar forças restritivas e propulsoras para o controle da Dengue, segundo a perspectiva destes profissionais. O procedimento de coleta de dados se dará por meio de entrevistas, da seguinte forma: haverá abordagem individual, no próprio local de trabalho, utilizando um formulário com dados cadastrais e perguntas abertas sobre o problema de pesquisa. Os depoimentos serão registrados com gravador portátil de áudio (digital) para posteriores transcrição e análise.

DESCONFORTOS, RISCOS E BENEFÍcIOS: Existe a possibilidade de desconforto e risco mínimos para você que se submeter à coleta de dados. Isso porque, por mais que o objetivo das perguntas não seja de causar constrangimento, você pode se sentir desconfortável ao falar, por exemplo, de alguns aspectos profissionais do seu cotidiano. Entretanto, tal desconforto, se justifica pela contribuição esperada do trabalho, onde você, como entrevistado, será beneficiado com a oportunidade de expressar sua opinião sobre um importante problema de saúde pública, 
participando, assim, do enfrentamento e da construção de um conhecimento mais aprofundado sobre o agravo no nível local.

FORMA DE ACOMPANHAMENTO E ASSINTÊNCIA: Caso você não se sinta bem pelo possível desconforto mencionado, ou por outros motivos relacionados ao estudo, esclarecemos que o pesquisador estará à disposição para oferecer o aporte emocional necessário, avaliando inclusive, a necessidade de encaminhamento para acompanhamento com um Psicólogo da Secretaria Municipal de Saúde de AlfenasMG.

\section{GARANTIA DE ESCLARECIMENTO, LIBERDADE DE RECUSA E GARANTIA DE} SIGILO: Você será esclarecido(a) sobre a pesquisa em qualquer aspecto que desejar. Você é livre para recusar-se a participar, retirar seu consentimento ou interromper a participação a qualquer momento. A sua participação é voluntária e a recusa em participar não irá acarretar qualquer penalidade ou perda de benefícios. O pesquisador irá tratar a sua identidade com padrões profissionais de sigilo. Os resultados da pesquisa serão enviados para você e permanecerão confidenciais. Seu nome ou o material que indique a sua participação não será liberado sem a sua permissão. Você não será identificado(a) em nenhuma publicação que possa resultar deste estudo. Uma cópia deste consentimento informado será arquivada na Secretaria do Programa de Doutorado em Saúde na Comunidade, da Faculdade de Medicina de Ribeirão Preto, da Universidade de São Paulo e outra será fornecida a você.

\section{CUSTOS DA PARTICIPAÇÃO, RESSARCIMENTO E INDENIZAÇÃO POR} EVENTUAIS DANOS: A participação no estudo não acarretará custos para você e não estará disponível nenhuma compensação financeira adicional. No caso de você sofrer algum dano decorrente dessa pesquisa, o projeto não prevê forma alguma de compensação, inexistindo, portanto, qualquer tipo de seguro, neste sentido. 


\section{DECLARAÇÃO DO(A) PARTICIPANTE:}

$\mathrm{Eu}$

esclareci minhas dúvidas. Sei que em qualquer momento poderei solicitar novas informações e motivar minha decisão se assim o desejar. O pesquisador Murilo César do Nascimento e o professor orientador Antonio Luiz Rodrigues-Júnior certificaram-me de que todos os dados desta pesquisa serão confidenciais. Também sei que caso existam gastos adicionais, estes serão custeados pelo responsável da pesquisa. Em caso de dúvidas poderei chamar o doutorando Murilo César do Nascimento e o professor orientador Antonio Luiz Rodrigues-Júnior, nos telefone (35) 9163-2720 e (16) 3602-2537, ou o Comitê de Ética em Pesquisa do Hospital das Clínicas e da Faculdade de Medicina de Ribeirão Preto, sito à Avenida dos Bandeirantes, $\mathrm{n} . .^{3900}$, Campus Universitário, Monte Alegre - Ribeirão Preto, SP, CEP 14048-900, Telefone: (16) 3602-2228, E-mail: cep@hcrp.fmrp.usp.br. Declaro que concordo em participar desse estudo. Recebi uma cópia deste termo de consentimento livre e esclarecido e me foi dada a oportunidade de ler e esclarecer as minhas dúvidas.

\begin{tabular}{ccc}
\hline Nome & Assinatura do(a) Participante & Local e Data \\
& & \\
\hline Nome & Assinatura da Testemunha & Local e Data \\
\hline Nome & Assinatura do Pesquisador & Local e Data \\
& \\
\hline Nome & Assinatura do Orientador & Local e Data
\end{tabular}




\section{APÊNDICE D - Relação da Produção Bibliográfica Derivada da Pesquisa}

\section{Artigos aceitos para publicação}

NASCIMENTO, M. C.; RODRIGUES-JÚNIOR, A. L. Dengue e Intersetorialidade: Representações Sociais de Enfermeiros da Atenção Primária à Saúde. Nursing (São Paulo), 2016.

NASCIMENTO, M. C.; RODRIGUES-JÚNIOR, A. L. Representações Sociais sobre a Dengue: uma Revisão Integrativa. Revista de Enfermagem do Centro-Oeste Mineiro (RECOM), 2016.

\section{Resumos publicados em anais de eventos}

NASCIMENTO, M. C.; RODRIGUES-JÚNIOR, A. L. Dengue e Intersetorialidade: Representações Sociais das Enfermeiras da Atenção Primária à Saúde de Alfenas-MG. In: I Simpósio Nacional de Residências na Atenção Básica / Saúde da Família, 2015, São João del-Rei. Anais do I Simpósio Nacional de Residências na Atenção Básica / Saúde da Família. São João del-Rei, Minas Gerais: Universidade Federal de São João del-Rei, 2015. v. 1.

NASCIMENTO, M. C.; RODRIGUES-JÚNIOR, A. L. Representações Sociais Sobre a Dengue: Uma Revisão Integrativa. In: I Simpósio Mineiro de PósGraduação, Saúde Pública e Desenvolvimento Sustentado, 2015, Alfenas / MG. Anais do I Simpósio Mineiro de Pós-Graduação, Saúde Pública e Desenvolvimento Sustentado. Alfenas, Minas Gerais: Universidade Federal de Alfenas, 2015.

\section{Artigo submetido para publicação}

NASCIMENTO, M. C.; RODRIGUES-JÚNIOR, A. L. Significados da Dengue para Enfermeiras da Atenção Primária à Saúde. Revista Latino-Americana de Enfermagem, 2016. 


\section{APÊNDICE E - Comprovantes de Aceites, de Publicações e de Submissão}

\section{Rursing}

REVISTA NURSING (ISSN 1415-8264)

Editora MPM Comunicação -Av. Yojiro Takaoka, 4384, sala 705 -

Conjunto 5209, Santana do Parnaíba-SP

E-mail: atendimento@mpmcomunicacao.com.br

0xx 1141521879

\section{DECLARAÇÃo}

Declaramos para os devidos fins que o artigo "Dengue e Intersetorialidade: Representações Sociais de Enfermeiros da Atenção Primária à Saúde", de autoria de Murilo César do Nascimento e Antonio Luiz Rodrigues Junior, foi aprovado para publicação pela Comissão Editorial da Revista Nursing. Informamos que o artigo encontra-se no prelo e será publicado na edição 219, 2016.

São Paulo, 27 de Janeiro de 2016.

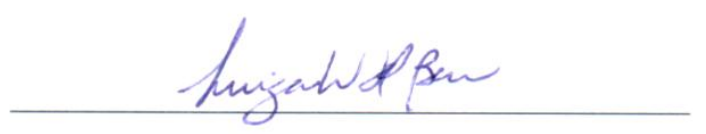

Luiza Watanabe Dal Ben

Diretora científica da revista Nursing 


\section{Aurs}

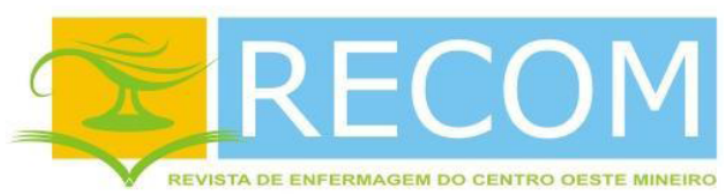

\section{Declaração}

Declaro, para os devidos fins, que o artigo intitulado: "REPRESENTAÇÕES SOCIAIS SOBRE A DENGUE: UMA REVISÃO INTEGRATIVA", dos autores: Murilo César do Nascimento Antônio Luiz Rodrigues Júnior, foi aceito para publicação na revista Centro Oeste Mineiro (RECOM) na data de 09/12/2015.

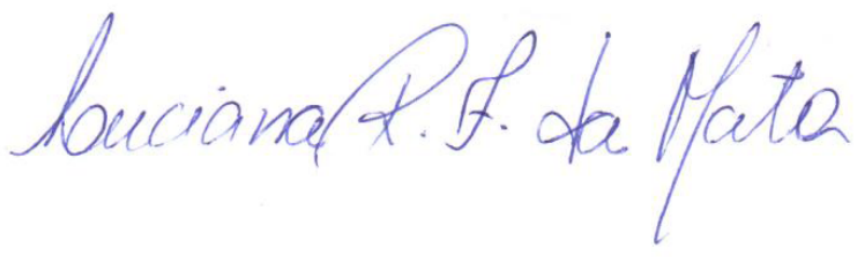

Luciana Regina Ferreira da Mata

Editora Chefe da RECOM

28, de janeiro de 2016. 


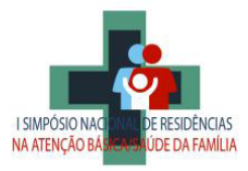

ISSN: 2446-953X

Categoria: Relato de Pesquisa

Tema: Vigilância epidemiológica e sanitária

\section{DENGUE E INTERSETORIALIDADE: REPRESENTAÇÕES SOCIAIS DOS ENFERMEIROS DA ATENÇÃO PRIMÁRIA À SAÚDE DE ALFENAS-MG}

Murilo César do Nascimento ${ }^{1}$

Antonio Luiz Rodrigues-Júnior ${ }^{2}$

Introdução: A dengue é uma doença viral geralmente transmitida pelo mosquito Aedes aegypti, cujo número de infecções tem aumentado em escala global, provocando impactos na economia de diversos países e constituindo um importante problema de saúde pública da atualidade. Diante da sua relevância clínica e epidemiológica, são necessárias ações intersetoriais que integrem o maior número de atores sociais possíveis na mobilização contra a doença. Acredita-se que acessar as Representações Sociais dos Enfermeiros da Atenção Primária à Saúde de Alfenas-MG sobre a Dengue seja importante para o "(re)conhecimento" do problema no nível local.

Objetivo: O objetivo específico foi de investigar a opinião dos Enfermeiros da Atenção Primária à Saúde de Alfenas/MG sobre quem deveria fazer parte do trabalho de enfrentamento da Dengue no Município.

Metodologia: Tratou-se de uma Pesquisa de Representação Social, de abordagem qualitativa, realizada em dezembro de 2014, em que se entrevistaram os Enfermeiros da Atenção Primária à Saúde de uma cidade Sul-Mineira. A elas foi perguntado: Do seu ponto de vista, quais instituições, setores e atores deveriam fazer parte do trabalho de enfrentamento da Dengue no Município de Alfenas-MG? Para a organização, exploração e a análise do material utilizou-se a Técnica do Discurso do Sujeito Coletivo - DSC, fundamentada na Teoria das Representações Sociais - TRS. Obteve-se aprovação por Comitê de Ética em Pesquisa (CAAE $n^{\circ}$ 20189313.4.0000.5440).

Resultados: Registrou-se 13 Ideias Centrais (IC): IC 1 - Todos já estão envolvidos; IC 2 - Falta o envolvimento da população; IC 3 - Tem que haver intersetorialidade entre a Saúde e outros Setores; IC 4 - Todos devem participar; IC 5 - Importância da área da Educação; IC 6 - Empresas e trabalhadores para além do setor saúde; IC 7 Tem sido centrado no Setor de Vigilância Epidemiológica; IC 8 - Deveria haver mais integração Intra-Setor Saúde; IC 9 - Responsabilidade do Setor Saúde e da Comunidade; IC 10 - As Universidades; IC 11 - Prefeitura e Gestores da Saúde; IC 12 - Principalmente a Estratégia Saúde da Família e os Agentes de Endemias; IC 13 - É responsabilidade do setor publico e do setor privado.

Considerações finais: A Representação Social que se destacou por apresentar grande força e alta amplitude foi a de que: "Tem que haver intersetorialidade entre a

\footnotetext{
${ }^{1}$ Enfermeiro. Mestre em Saúde na Comunidade. Professor Assistente na Escola de Enfermagem da Universidade Federal de Alfenas, UNIFAL-MG. E-mail: murilonascimento@usp.br

2 Odontólogo. Doutor em Epidemiologia. Professor Associado do Departamento de Medicina Social da Faculdade de Medicina de Ribeirão Preto da Universidade de São Paulo, USP. E-mail: alrj@fmrp.usp.br
} 


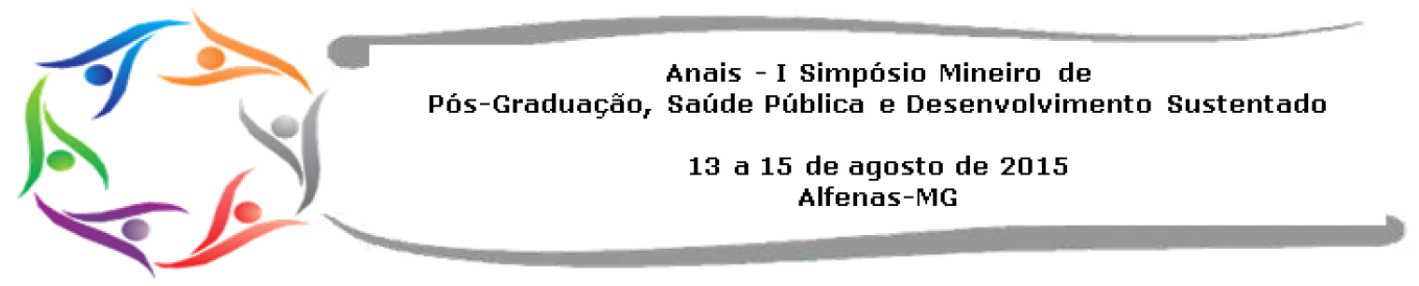

\title{
Representações Sociais Sobre a Dengue: Uma Revisão Integrativa
}

\author{
Murilo César do Nascimento ${ }^{1}$, Antonio Luiz Rodrigues-Júnior ${ }^{2}$
}

1. Professor Assistente da Universidade Federal de Alfenas. Doutorando em Saúde na Comunidade pelo Departamento de Medicina Social da Faculdade de Medicina de Ribeirão Preto - Universidade de São Paulo, USP.

2. Professor Associado do Departamento de Medicina Social da Faculdade de Medicina de Ribeirão Preto da Universidade de São Paulo, USP.

E-mail (do relator): murilonascimento@usp.br

Palavras Chave: Dengue. Psicologia Social. Ciências Sociais. Revisão. Publicações de Divulgação Científica.

\section{Introdução}

Considerando a importância da Dengue como problema de saúde pública e pensando nas possíveis contribuições de uma abordagem compreensiva das ciências sociais e humanas para o seu reconhecimento é que se decidiu realizar uma revisão integrativa sobre as Representações Sociais da Dengue.

A teoria das Representações Sociais trata da produção dos saberes sociais, foca na análise da construção e transformação do conhecimento social e tenta explicar como a ação e o pensamento se interligam na dinâmica social ${ }^{1}$. O objetivo deste trabalho constituiu, portanto, em investigar e descrever quais pesquisas de representações sociais sobre dengue são encontradas na literatura científica.

\section{Metodologia}

A revisão integrativa foi escolhida como método de revisão e pautou-se nos seis passos seguintes: 1) elaboração da questão de pesquisa; 2) busca na literatura dos estudos primários; 3) extração de dados; 4) avaliação dos estudos primários; 5) análise e síntese dos resultados; e 6) apresentação da revisão.

A questão norteadora da pesquisa foi: Quais pesquisas de representações sociais sobre dengue são encontradas na literatura? A busca dos estudos foi realizada em março de 2015 nas bases de dados National Library of Medicine National Institutes of Health (PubMed/MEDLINE), Literatura Latino-Americana e do Caribe em Ciências da Saúde (LILACS) e na biblioteca Scientific Eletronic Library On-line (SciELO). Na PubMed/MEDLINE utilizou-se os descritores controlados: social representations; dengue, e o operador booleano and. Já para a base de dados LILACS e a Biblioteca SciELO, optou-se pelos mesmos termos só que na língua portuguesa: representações sociais; dengue.

Como critérios de inclusão adotaram-se: (a) trabalhos em línguas portuguesa, inglesa e espanhola, (b) publicados em qualquer período de tempo, (c) que abordassem representações sociais de algum aspecto relacionado à dengue e (d) que tivessem o Discurso do Sujeito Coletivo (DSC) como técnica de tabulação e análise de dados qualitativos. Não houve delimitação do ano de publicação com a finalidade de assegurar busca ampla. A seleção inicial se deu após leitura minuciosa do título e do resumo, seguida por leitura integral e avaliação dos trabalhos quanto ao atendimento dos critérios de inclusão e resposta à questão da pesquisa. Os estudos que apresentaram duplicidade tiveram as repetições excluídas da análise.

Para auxiliar nas etapas de extração de dados, avaliação dos estudos primários e análise e síntese dos resultados foi elaborada uma planilha que conformou os seguintes campos: autores, periódico, ano de publicação, base de dados, título, objetivo principal, tipo de estudo, técnica de coleta de dados, referencial teórico-metodológico, atores sociais e materiais pesquisados, resultados e conclusões.

\section{Resultados}

Foram obtidos 8 trabalhos elegíveis, publicados entre os anos de 2004 e 2014, sendo 6 artigos e 2 dissertações; destes, um artigo foi excluído por não se enquadrar no critério de utilização do Discurso do Sujeito Coletivo (DSC). Assim, a análise final foi realizada com 7 estudos, cujos periódicos e anos da publicação, títulos, objetivos principais, tipos de estudo e de coleta de dados, bem como os atores sociais e materiais pesquisados foram apresentados na forma de um quadro síntese. A seguir é apresentada parte do quadro, contendo o periódico/ano de publicação e os títulos dos estudos. 


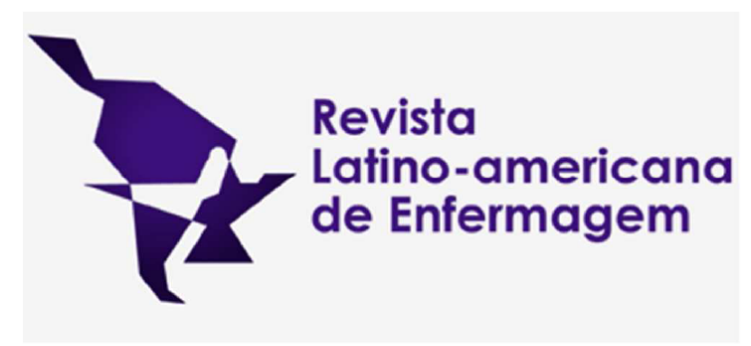

\section{Significados da Dengue para Enfermeiras da Atenção Primária à Saúde}

\begin{tabular}{|r|l|}
\hline Journal: & Revista Latino-Americana de Enfermagem \\
\hline Manuscript ID & Draft \\
\hline Manuscript Type: & Original Article \\
\hline Study Area: & Public Health Nursing < Nursing, Social Psychology, Interdisciplinary \\
\hline Select the study type: & Qualitative Research, Social Representation Research \\
\hline $\begin{array}{r}\text { Select the research } \\
\text { design/procedure: }\end{array}$ & $\begin{array}{l}\text { Representações Sociais Research, Discourse of the collective subject, } \\
\text { Action Research }\end{array}$ \\
\hline Keywords in English: & $\begin{array}{l}\text { Dengue, Epidemics, Public Health, Qualitative Research, Nursing, } \\
\text { Psychology, Social }\end{array}$ \\
\hline
\end{tabular}

\section{SCHOLARONE}

Manuscripts 


\section{ANEXO A - Parecer da Secretaria Municipal de Saúde - SMS}

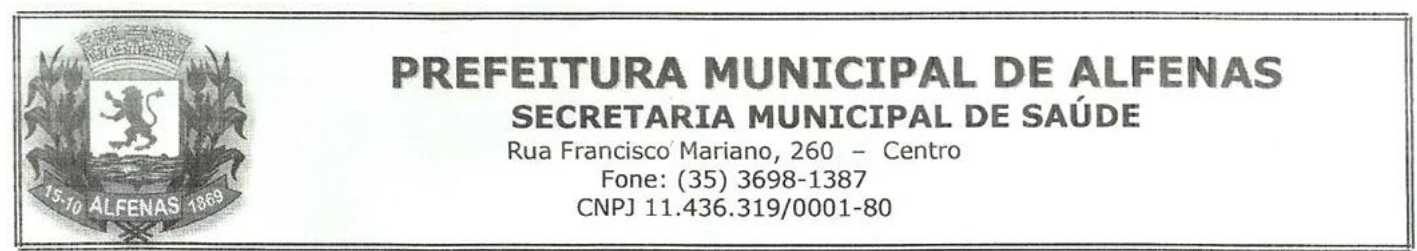

Parecer $\mathrm{N}^{\circ}: 11$

Data: 02 de Agosto de 2013

Instituição: Faculdade de Medicina de Ribeirão Preto

\section{PARECER PROJETO ACADÊMICO E TERMO DE COMPROMISSO}

O projeto "Representações Sociais de Enfermeiros da Atenção Primária à Saúde sobre a Dengue em Alfenas - MG" realizado por Murilo César do Nascimento, foi avaliado pela Comissão de Avaliação de Projetos de Pesquisa da Secretaria Municipal de Saúde de Alfenas, constituída pela resolução $\mathrm{N}^{\circ} 01$ de 08 Maio de 2013, foi deferido com as seguintes condições:

- Apresentar os resultados após a conclusão do trabalho para a Comissão de Projetos e para o setor de Zoonose
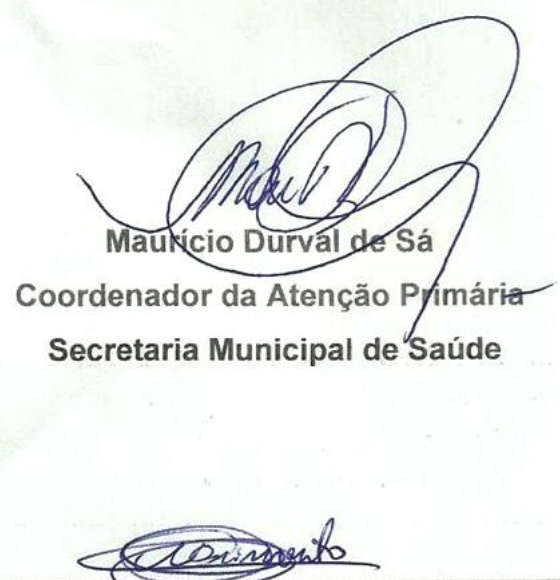

Murilo César do Nascimento 


\section{ANEXO B - Parecer da Unidade de Pesquisa Clínica - UPC}

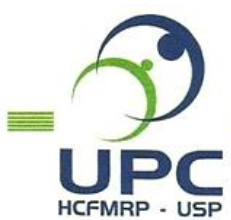

HOSPITAL DAS CLINICAS DA FACULDADE DE MEDICINA DE RIBEIRÃO PRETO DA UNIVERSIDADE DE SÃO PAULO

www.hcrp.fmrp.usp.br

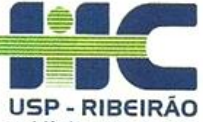

PROJETO DE PESQUISA

Ribeirão Preto, 08 de $\operatorname{tons} 0$ - 2010 .

Ilustríssima Senhora

Dr. ${ }^{a}$ Marcia Guimarâes Villanova

Sistema UPC n 7176

MD. Coordenadora do Comitê de Ética em Pesquisa

Do HCFMRP-USP e da FMRP-USP

Senhora Coordenadora,

Encaminho em anexo o projeto de pesquisa intitulado

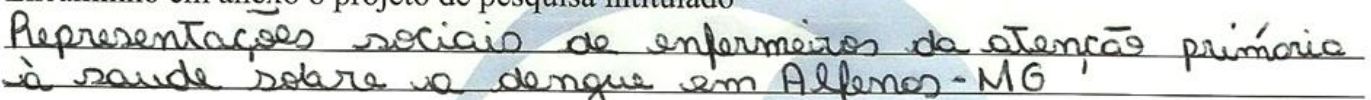

juntamente com a documentação necessária para avaliação ética deste Comitê.

O projeto acima mencionado será desenvolvido no (a) deportomento de medecina secual

Informo também que o pesquisador responsável e o orientador possuem currículo Lattes.

$\mathrm{O}$ orçamento do presente projeto foi analisado pela equipe técnica da UPC antes da submissão ao Comitê e foi APLOULAD)

Rafael Maia/dos Santios?

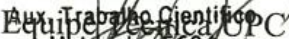

Atenciosamente,

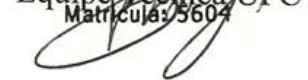

Unilo léser do Vosimento

Pesquisador Principal ou Aluno (nome completo e assinatura)

AnTONio Juiz RoDniGues In

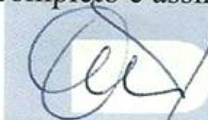

Pesquisador Principal ou Orientador (nome completo e assinatura)

De acordo:

17 Prof. Or. Atonso Dinis Costa Passos

Chefe de Departamento (assinatura e carimbo)

Chefe do Ambulatório/ Laboratório (assinatura e carimbo)

Obs.: Caso a.gum chefe possua vinculo com a pesquisa, deverá ser solicitada assinatura do suplente.

Ap śs assinatura em todos os campos, digitalizar toda a documentação do check list e encaminhar ao CEP via Plataforma Brasil.

HC - Campus Universitário

Monte Alegre 14048-900 Ribeirão Preto SP 


\section{ANEXO C - Folha de Rosto para Pesquisa - Plataforma Brasil}

Platoforma MINISTÉRIO DA SAÚDE - Conselho Nacional de Saúde - Comissāo Nacional de Ética em Pesquisa - CONEP Brasil

FOLHA DE ROSTO PARA PESQUISA ENVOLVENDO SERES HUMANOS

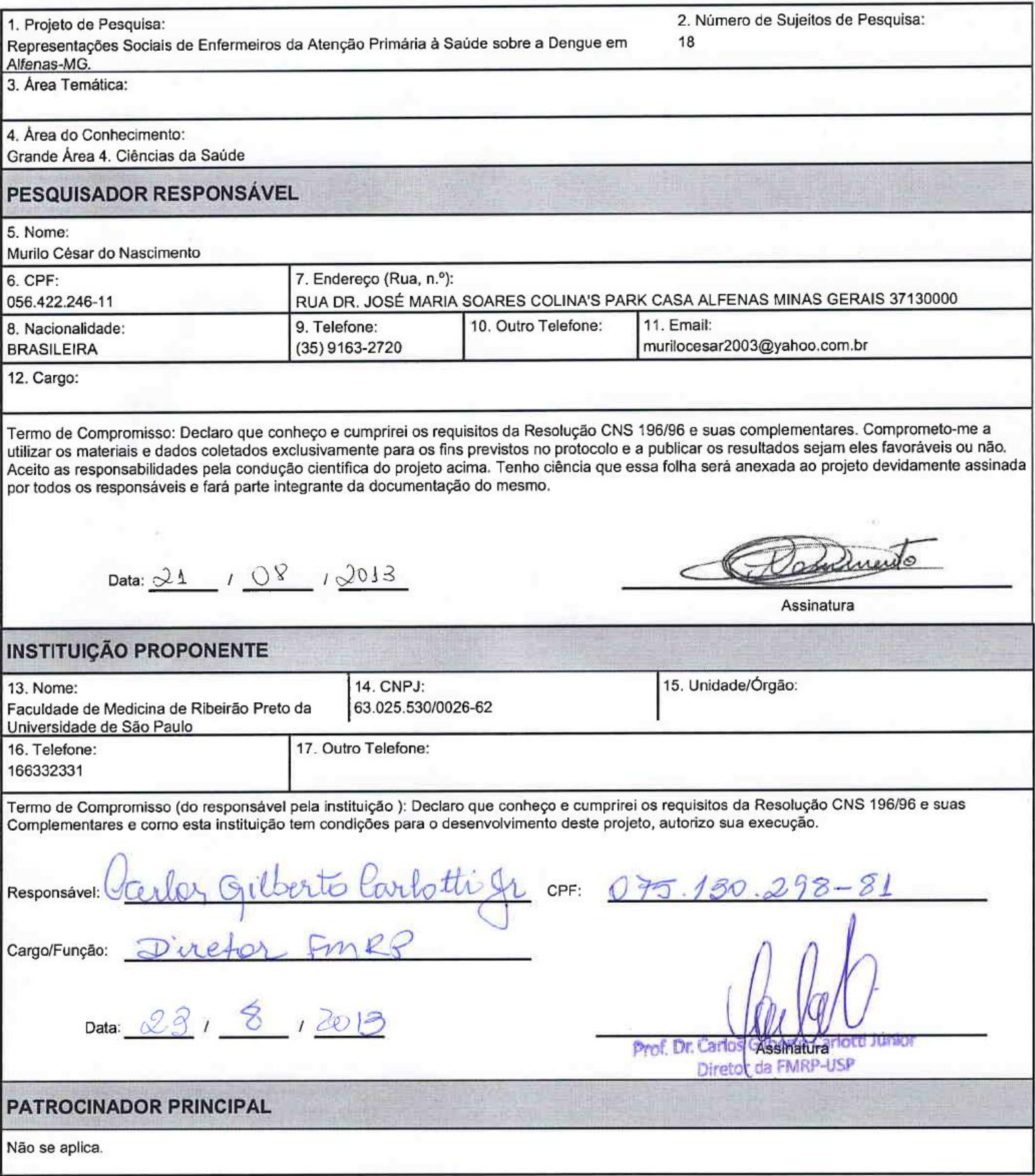




\section{ANEXO D - Instrumento de Análise do Discurso 1 - IAD1}

\begin{tabular}{|c|c|c|c|}
\hline |AD1-1 & \multicolumn{3}{|c|}{$\begin{array}{l}\text { Instrumento de Análise do Discurso 1: } \\
\text { Pergunta 1: Se uma amiga Ihe perguntasse o que a Dengue significa para você, } \\
\text { qual seria a sua resposta? }\end{array}$} \\
\hline Entrevistado & Expressões Chave & Ideias Centrais & $\begin{array}{l}\text { Agrupa- } \\
\text { mento }\end{array}$ \\
\hline $\begin{array}{l}\text { HPSH001b } \\
\text { CPA }\end{array}$ & $\begin{array}{l}\text { [...] Nossa, eu acho que é um período } \\
\text { curto mas é muito ruim. Eu tive } \\
\text { Dengue, e foi bem leve, foi horrível. E } \\
\text { todo mundo comenta que não é nada } \\
\text { bom, é pior que cê ter um resfriado. } \\
\text { É... eu não gostaria de ter não. [...] } \\
\text { Uma coisa muito incômoda, muito } \\
\text { chata mesmo pra mim. Não é coisa de } \\
\text { outro mundo não porque ela veio, do } \\
\text { mesmo jeito que veio foi embora, né? } \\
\text { Foi rápido, não foi complicado nem } \\
\text { nada. Olha, você se sente mal o } \\
\text { tempo todo, cê se sente enfraquecido, } \\
\text { você não consegue fazer, desenvolver } \\
\text { nada. Cê levanta, suas pernas ficam } \\
\text { bambas, né? No caso, as pessoas } \\
\text { relatam muita dor de cabeça, eu tive } \\
\text { pouco episódio. [...] Dor no corpo, a } \\
\text { dor na cabeça que não foi muito, dor } \\
\text { no olho, né? Depois fiquei toda } \\
\text { coçando, né? Tive enjoo, vômito, a } \\
\text { boca amarga. [...] Mas foi isso que eu } \\
\text { senti. } \\
\text { Ela é, pra mim... Mais uma doença } \\
\text { pra gente cuidar! [...] A Dengue } \\
\text { significa pra mim quando chega um } \\
\text { paciente eu falo: "Ai meu Deus, mais } \\
\text { um pra nós cuidarmos... porque a } \\
\text { gente cuida do paciente, tá? [...] mais } \\
\text { um pra gente cuidar, pra ter cuidado; } \\
\text { [...] Porque você fica atento, cê fica } \\
\text { lembrando daquela pessoa, cê fala: } \\
\text { "Oh, cê volta tal dia!" [...] mudou do } \\
\text { ano passado pra cá, né? Essa } \\
\text { atenção... essa atenção da gente } \\
\text { cuidar, porque antes era um caso ou } \\
\text { outro que cê nem ficava sabendo, a } \\
\text { partir do momento que veio, que a }\end{array}$ & $\begin{array}{l}2^{\text {a }} \text { IC: Mais uma } \\
\text { doença pra } \\
\text { gente cuidar }\end{array}$ & $\underset{\substack{\text { Outros } \\
\text { significados }}}{\mathbf{K}}$ \\
\hline
\end{tabular}




\begin{tabular}{|c|c|c|c|}
\hline & $\begin{array}{l}\text { gente sentiu que precisava cuidar } \\
\text { daquele paciente, [...] foi isso. }\end{array}$ & & \\
\hline $\begin{array}{l}\text { HPSH002b } \\
\text { DMG }\end{array}$ & $\begin{array}{l}\text { [...] Um descuido das pessoas. [...] Eu } \\
\text { tava conversando com uma [...] } \\
\text { agente da epidêmica passa aqui, aí } \\
\text { ela falou assim que a maioria das } \\
\text { coisa do serviço dela é catar lixo do } \\
\text { quintal das pessoas. [...] Então, tipo } \\
\text { assim, é uma doença que tá sendo } \\
\text { contaminada né, por descuido da } \\
\text { população... [...] Falta mais da } \\
\text { população ter uma conscientização... } \\
{[\ldots] \text { Eu acho que é descuido das }} \\
\text { pessoas, resumindo numa palavra, } \\
\text { numa frase. [...] Pela forma que ela é } \\
\text { transmitida né, porque a maioria... } \\
\text { água parada, ali tem né, vai ter a } \\
\text { larva, aí vai ter né produção do } \\
\text { mosquito... [...]Que passe, vamos } \\
\text { supor, que passe uma vez por mês, } \\
\text { dá as orientações, cê ela passar daqui } \\
15 \text { dias tá lá o lixo de novo... [...] Eu } \\
\text { acho que é isso... }\end{array}$ & $\begin{array}{l}\text { IC: Descuido } \\
\text { das pessoas }\end{array}$ & $\underset{\substack{\text { Descuido das } \\
\text { pessoas }}}{\text { C }}$ \\
\hline $\begin{array}{l}\text { HPSH003b } \\
\text { FAP }\end{array}$ & $\begin{array}{l}\text { Hoje, pra mim, a Dengue está sendo } \\
\text { mais um problema de saúde pública } \\
\text { mesmo, porque [...] não é só a pessoa } \\
\text { que pega Dengue que tem que se } \\
\text { preocupar, né? Tem que, todo ao } \\
\text { redor tem que tá preocupando, porque } \\
\text { o mosquito, ele vai pra todo lado, e às } \\
\text { vezes você vai viajar, você traz pra } \\
\text { cidade. } \\
\text { [...] Eu acho que é um caso muito } \\
\text { grave, apesar de ser um tempo curto } \\
\text { do processo dela, de } 7 \text { a } 20 \text { dias, mas } \\
\text { esse ano a gente teve casos muito } \\
\text { graves aqui no bairro, que no ano } \\
\text { passado parecia uma gripinha muito } \\
\text { fraquinha, no máximo em } 7 \text { dias tinha } \\
\text { acabado, agora dessa vez está } \\
\text { durando } 15,20 \text { dias... então eu acho } \\
\text { que tá piorando a cada vez mais, tem } \\
\text { que se preocupar mesmo. Porque não } \\
\text { depende só da gente orientar né, se a } \\
\text { pessoa não aplicar o que a gente } \\
\text { orienta, que não pode deixar água }\end{array}$ & $\begin{array}{l}\text { 1a IC: Problema } \\
\text { de } \\
\text { pública }\end{array}$ & $\begin{array}{c}\text { B } \\
\text { Problema de } \\
\text { saúde pública }\end{array}$ \\
\hline
\end{tabular}




\begin{tabular}{|c|c|c|c|}
\hline & $\begin{array}{l}\text { parada, evitar todo tipo né, não } \\
\text { adianta nada nosso trabalho. }\end{array}$ & & \\
\hline $\begin{array}{l}\text { HPSH004b } \\
\text { ECLF }\end{array}$ & $\begin{array}{l}\text { Preocupação. Porque assim, é um } \\
\text { caso que tá todo mundo assim } \\
\text { preocupado, entre aspas né, } \\
\text { preocupado com a casa do outro e } \\
\text { esquece que dentro da sua casa } \\
\text { também tem esse problema. [...] } \\
\text { Dengue é uma doença que pode } \\
\text { matar se não for bem tratada, então a } \\
\text { gente tem que ficar em cima do } \\
\text { paciente, tem que monitorar. [...] } \\
\text { Porque querendo ou não é uma } \\
\text { preocupação, porque pode matar né? } \\
\text { E por mais a gente informa o } \\
\text { paciente, informa a população, ainda } \\
\text { tá um descaso vindo da população. } \\
\text { Eles querem cobrar do governo, eles } \\
\text { querem cobrar da prefeitura, mas a } \\
\text { gente tem que fazer nossa parte. }\end{array}$ & $\begin{array}{l}\text { IC: Uma } \\
\text { preocupação }\end{array}$ & $\frac{\mathbf{F}}{\begin{array}{c}\text { Preocupação } \\
\text { e medo }\end{array}}$ \\
\hline $\begin{array}{l}\text { HPSH005b } \\
\text { RCS }\end{array}$ & $\begin{array}{l}\text { [...] A Dengue significa pra mim uma } \\
\text { doença causada pela falta de cuidado } \\
\text { né com resíduos, [...] com restos de } \\
\text { alimentos, uma falta mesmo de } \\
\text { cuidado da população com a saúde, } \\
\text { né? Uma falta de cuidado, porque a } \\
\text { partir do momento, se a gente } \\
\text { trabalhasse melhor, conforme já te } \\
\text { falei, trabalhasse melhor a nossa } \\
\text { higiene, os nossos rejeitos de lixo, } \\
\text { tudo, acho que a gente poderia evitar } \\
\text { né? Seria uma falta disso, porque hoje } \\
\text { em dia a gente produz muito lixo né, a } \\
\text { gente produz uma quantidade } \\
\text { razoável de lixo, e não cuida né, não } \\
\text { dá tanto o destino adequado, vamos } \\
\text { falar isso. } \\
\text { [...] Eu falo que a Dengue também é } \\
\text { um produto da falta de educação do } \\
\text { indivíduo né? Da falta de educação } \\
\text { [...] A gente é muito mal educado } \\
\text { nesse sentido, a gente não tem } \\
\text { cuidado, não tem. Vai jogar, não tem } \\
\text { o cuidado de abrir o lixo, pra por o lixo } \\
\text { dentro do lixo, joga fora e não coisa... } \\
\text { né? [...] É a falta de educação do ser } \\
\text { humano e a falta do destino adequado }\end{array}$ & $\begin{array}{l}\text { 1" IC: Doença }^{\text {a }} \\
\text { causada pela } \\
\text { falta de cuidado } \\
\text { com resíduos }\end{array}$ & $\begin{array}{c}\text { D } \\
\text { Consequência } \\
\text { da falta dea } \\
\text { educą̧ăo }\end{array}$ \\
\hline
\end{tabular}




\begin{tabular}{|c|c|c|c|}
\hline & do lixo. & & \\
\hline $\begin{array}{l}\text { HPSH006b } \\
\text { APOG }\end{array}$ & $\begin{array}{l}\text { Pra mim seria a picada do mosquito } \\
\text { né, Aedis aegipty, geralmente é } \\
\text { causada por [...] acúmulo de lixos, né, } \\
\text { acúmulo de água nos pneus, em } \\
\text { garrafas, entendeu? [...] Os sintomas, } \\
\text { né, mais comuns... dor no fundo dos } \\
\text { olhos, febre alta, em torno de } 39,5^{\circ} \text {, } \\
{[\ldots] \text { às vezes começa aparecer }} \\
\text { aqueles formigamento no corpo, tudo } \\
\text { vermelhinho, a partir do sexto, sétimo } \\
\text { dia, o nível de plaquetas começa a } \\
\text { baixar, abaixo de } 150 \text { mil. Pra mim é a } \\
\text { picada do mosquito entendeu, que } \\
\text { pode causar a Dengue. }\end{array}$ & $\begin{array}{l}\text { IC: A picada do } \\
\text { mosquito }\end{array}$ & $\begin{array}{c}\mathbf{H} \\
\text { Doença } \\
\text { causada pela } \\
\text { picada do } \\
\text { mosquito }\end{array}$ \\
\hline $\begin{array}{l}\text { HPSH007b } \\
\text { WMS }\end{array}$ & $\begin{array}{l}\text { Dengue é uma doença viral, febril. [...] } \\
\text { Porque a gente como Enfermeiro, } \\
\text { como trabalhador da área de saúde, a } \\
\text { gente tem a nossa visão técnica né? } \\
\text { Então eu ia falar que é uma doença } \\
\text { viral, uma doença febril, é uma } \\
\text { doença que apresenta tais sintomas. } \\
\text { [...] Então meu ponto de vista técnica } \\
\text { é uma doença viral, febril, que não } \\
\text { tem medicação específica, a gente } \\
\text { trata somente os sintomas, observa } \\
\text { sinais de alerta. } \\
\text { E eu acho que é um problema de } \\
\text { saúde pública. Porém, se a } \\
\text { participação popular da comunidade } \\
\text { não existir, a gente não vai conseguir } \\
\text { trabalhar o controle dela. }\end{array}$ & 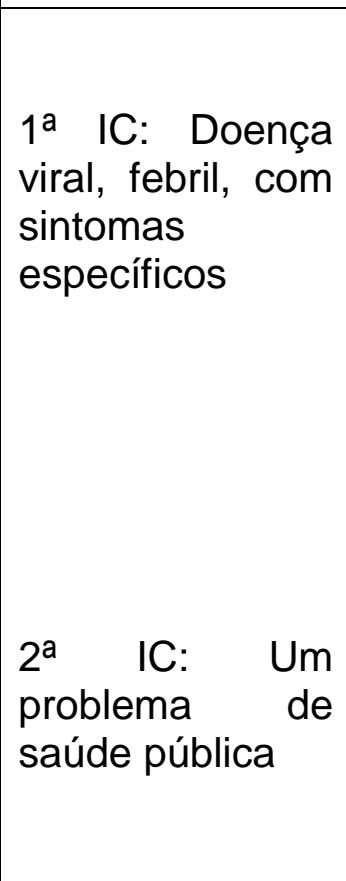 & $\begin{array}{l}\text { B } \\
\text { Problema de } \\
\text { saúde pública }\end{array}$ \\
\hline $\begin{array}{l}\text { HPSH008b } \\
\text { AAS }\end{array}$ & $\begin{array}{l}\text { [...] Que a Dengue é uma doença... } \\
\text { causada pelo mosquito que pode } \\
\text { levar à morte. Que precisa ser tratada, } \\
\text { que precisa ser notificada, e cuidada. } \\
\text { Pra mim a Dengue é isso. }\end{array}$ & $\begin{array}{l}\text { IC: } r \text { Doença } \\
\text { causada pelo } \\
\text { mosquito, que } \\
\text { pode levar à } \\
\text { morte }\end{array}$ & $\begin{array}{c}\mathbf{H} \\
\text { Doença } \\
\text { causada pela } \\
\text { picada do } \\
\text { mosquito }\end{array}$ \\
\hline $\begin{array}{l}\text { HPSH009b } \\
\text { AS }\end{array}$ & $\begin{array}{l}\text { Eu acho que é uma doença de... } \\
\text { saúde primária, pública, e que [...] o } \\
\text { maior problema é meio ambiente, é } \\
\text { sanitário, sabe, é falta de estrutura do } \\
\text { ambiente mesmo. [...] Então eu acho } \\
\text { que é uma doença de saúde pública }\end{array}$ & IC: Uma doença & $\begin{array}{c}\text { B } \\
\text { Problema de }\end{array}$ \\
\hline
\end{tabular}




\begin{tabular}{|c|c|c|c|}
\hline & $\begin{array}{l}\text { por causa disso, por causa da falta de } \\
\text { saneamento básico memo. A gente tá } \\
\text { voltando à estaca meio que zero, por } \\
\text { mais que a gente tá atualizado com os } \\
\text { resíduos, com a coleta de lixo, ainda } \\
\text { ficaram coisas. [...] Então, pra mim, é } \\
\text { uma doença a nível de meio ambiente } \\
\text { mesmo, poblema primário, básico. [...] } \\
\text { Você pensar como que um mosquito, } \\
\text { [...] que por causa de uma água, ele } \\
\text { faz esse estrago todo. }\end{array}$ & $\begin{array}{|ll|}\text { de } & \text { saúde } \\
\text { pública } & \\
\end{array}$ & saúde pública \\
\hline $\begin{array}{l}\text { HPSH010b } \\
\text { ECPG }\end{array}$ & $\begin{array}{l}\text { Eu diria que a Dengue é uma doença } \\
\text { de, de país pobre, mas que } \\
\text { infelizmente a gente tá vivenciando } \\
\text { nos dias atuais [...]. } \\
\text { [...] por menos que pareça uma coisa } \\
\text { simples, não é tão simples. É uma } \\
\text { coisa que eu não gostaria de ter, que } \\
\text { ninguém na minha família tivesse, } \\
\text { mas que a gente tem que tomar os } \\
\text { cuidados para que ela não aconteça. } \\
\text { Então não ficar tão distante né, então } \\
\text { se policiar, né, com coisas simples, } \\
\text { mesmo dentro da nossa casa, as } \\
\text { nossas plantas, com a nossa } \\
\text { geladeira, com o nosso quintal, com } \\
\text { os nossos descartáveis que fica às } \\
\text { vezes entulhado [...]. Ela significa pra } \\
\text { mim, uma doença grave, que eu não } \\
\text { gostaria de ter. }\end{array}$ & $\begin{array}{l}\text { 2. IC: Uma } \\
\text { doença grave } \\
\text { que eu não } \\
\text { gostaria de ter }\end{array}$ & $\underset{\substack{\text { Outros } \\
\text { significados }}}{\mathbf{J}}$ \\
\hline $\begin{array}{l}\text { HPSH011b } \\
\text { VDR }\end{array}$ & $\begin{array}{l}\text { [...] É uma doença viral. Uma doença } \\
\text { viral e que pode causar febre, mal } \\
\text { estar, dor nas articulações, mas que, } \\
\text { que dependendo do tipo de Dengue, } \\
\text { [...] tem medicamento, tem solução, } \\
\text { ela vai curar. Não é uma doença } \\
\text { também de bicho de sete cabeças } \\
\text { não, eu não acho não! A partir do } \\
\text { momento que você diagnóstica bem } \\
\text { rápido e toma os devidos cuidados. } \\
\text { [...] Doença viral, viral, que tem } \\
\text { sintomas né, dor de cabeça, febre, } \\
\text { como sintoma de gripe, e mal estar, } \\
\text { só que tem que tomar medicamento, } \\
\text { dipirona... }\end{array}$ & $\begin{array}{l}\text { IC: Uma doença } \\
\text { viral }\end{array}$ & $\begin{array}{c}\mathbf{E} \\
\text { Doença viral }\end{array}$ \\
\hline
\end{tabular}




\begin{tabular}{|c|c|c|c|}
\hline $\begin{array}{l}\text { HPSH012b } \\
\text { NR }\end{array}$ & $\begin{array}{l}\text { [...] É uma doença que requer uma } \\
\text { atenção especial, um problema de } \\
\text { saúde pública. Mas, que se alguém } \\
\text { tiver Dengue, não pode deixar passar } \\
\text { batido, tem que procurar assistência } \\
\text { médica e fazer a parte da família. } \\
\text { Cada um correr atrás com o controle, } \\
\text { né? Mas é um problema de saúde [...] } \\
\text { que tem que ser olhado e é um } \\
\text { problema de saúde pública. Envolve } \\
\text { os profissionais e envolve a } \\
\text { comunidade, todo mundo é } \\
\text { responsável pela Dengue. }\end{array}$ & $\begin{array}{l}\text { IC: Doença que } \\
\text { requer uma } \\
\text { atenção } \\
\text { especial, um } \\
\text { problema de } \\
\text { saúde pública }\end{array}$ & $\begin{array}{c}\text { B } \\
\text { Problema de } \\
\text { saúde pública }\end{array}$ \\
\hline $\begin{array}{l}\text { HPSH013b } \\
\text { SMR }\end{array}$ & $\begin{array}{l}\text { [...] Pra mim foi né um desconforto } \\
\text { enorme, (risos), dores demais, né, e } \\
\text { assim... e a única coisa que a gente } \\
\text { quer é ficar de cama, né. Então assim, } \\
\text { eu acho que dificultou, deu trabalho } \\
\text { de vir trabalhar, né, e ficar tomando } \\
\text { remédio pra dor e eles não passa, } \\
\text { entendeu? Assim, ficar muitos dias, } \\
\text { né, esse desconforto, eu tive vômito, } \\
\text { entendeu? Assim, foi um desconforto } \\
\text { enorme que eu não desejo nem pro } \\
\text { pior inimigo meu. [...] A partir do } \\
\text { momento que você adquire a Dengue, } \\
\text { eu vou falar que é pensar em ficar de } \\
\text { cama e o mais quietinho possível, } \\
\text { porque é desconfortável demais. } \\
\text { Muito desconfortável, eu falo que eu } \\
\text { não queria Dengue, imagina as } \\
\text { crianças... Sofre muito, e olha, eu sofri } \\
\text { muito. [...] Mas o meu medo maior foi } \\
\text { pensar na Dengue hemorrágica, esse } \\
\text { eu tive medo, por causa do risco, né, } \\
\text { de levar ao óbito, né? Esse foi o } \\
\text { desconforto também, né, o físico né e } \\
\text { o mental da preocupação, né. }\end{array}$ & $\begin{array}{l}\text { IC: Desconforto } \\
\text { enorme }\end{array}$ & $\begin{array}{c}\text { A } \\
\text { Desconforto } \\
\text { enorme }\end{array}$ \\
\hline $\begin{array}{l}\text { HPSH014b } \\
\text { VLS }\end{array}$ & $\begin{array}{l}\text { A Dengue pra mim significa é, na } \\
\text { realidade, uma guerra patológica. } \\
\text { Porque cada época é algo diferente, } \\
\text { sintomatologia diferente, de paciente } \\
\text { pra paciente, de ano pra ano. O ano } \\
\text { passado foi uma sintomatologia que o } \\
\text { paciente apresentou e hoje, } \\
\text { apresentou esse ano, outro tipo de } \\
\text { sintomatologia. Então, eu acho que é, } \\
\text { na realidade, uma guerra que nós } \\
\text { estamos vivendo, tá? }\end{array}$ & $\begin{array}{l}\text { 1ㅁ IC: Uma } \\
\text { guerra }\end{array}$ & $\underset{\substack{\mathbf{J} \\
\text { Outros } \\
\text { significados }}}{ }$ \\
\hline
\end{tabular}




\begin{tabular}{|c|c|c|c|}
\hline & $\begin{array}{l}\text { O significado: tipo uma guerra, que } \\
\text { onde nós Enfermeiros, nós, todos da } \\
\text { área de saúde temos que enfrentar } \\
\text { essa epidemia, temos que, não só no } \\
\text { dia-a-dia, mas eu acho que temos que } \\
\text { estudar, [...] porque que o ano que } \\
\text { vem vai ser outro tipo; [...] a gente fica } \\
\text { realmente preocupado com isso. } \\
\text { [...] A Dengue se tornou um caso de } \\
\text { epidemia mesmo, tá? Onde nós } \\
\text { temos que nos enfrentar cada ano um } \\
\text { tipo de vírus diferente. } \\
\text { [...] Então eu acho que isso é a } \\
\text { Dengue para mim hoje, é uma } \\
\text { epidemia, já se tornou caso sério } \\
\text { dentro da saúde pública. [...] Nós } \\
\text { enfrentamos uma guerra com a } \\
\text { Dengue aqui nesses últimos meses. }\end{array}$ & $\begin{array}{l}2^{\mathrm{a}} \quad \mathrm{IC}: \\
\text { epidemia }\end{array}$ & $\stackrel{\text { I }}{\text { Epidemia }}$ \\
\hline $\begin{array}{l}\text { HPSH015b } \\
\text { DCC }\end{array}$ & $\begin{array}{l}\text { [...] A Dengue, pra mim, é uma } \\
\text { doença, uma questão de saúde } \\
\text { pública hoje. Por conta da falta de } \\
\text { cuidado das próprias pessoas, que } \\
\text { não cuidam do seu próprio quintal. } \\
\text { Também [...] tem muita gente que não } \\
\text { deixa aqueles agentes de endemia } \\
\text { entrar nas casas. [...] Uma falta de } \\
\text { cuidado, de algumas pessoas, que } \\
\text { causam um transtorno na vida de um } \\
\text { tanto de gente. }\end{array}$ & $\begin{array}{l}\text { IC: Uma questão } \\
\text { de } \\
\text { pública }\end{array}$ & $\begin{array}{c}\text { B } \\
\text { Problema de } \\
\text { saúde pública }\end{array}$ \\
\hline $\begin{array}{l}\text { HPSH016b } \\
\text { PLG }\end{array}$ & $\begin{array}{l}\text { [...] Preocupação, medo, é... acho que } \\
\text { a gente tem que dar mais informação, } \\
\text { acho que talvez mediante a este susto } \\
\text { que a população passou agora, talvez } \\
\text { tenha mais conscientização. [...] A } \\
\text { população não adere, não aceita, não } \\
\text { conc.. mesmo ficando doente, tá? } \\
\text { Acredito que naquela época deve ter } \\
\text { tomado algum cuidado maior, } \\
\text { resolveu tirar as coisas da horta, os } \\
\text { pneus, a gente já juntava e agora já } \\
\text { apagou da memória. Que é o perfil da } \\
\text { população né? [...] eu assisti de perto } \\
\text { e... e é muito triste né, as pessoas } \\
\text { dessa vez ficaram muito ruim. }\end{array}$ & $\begin{array}{l}\text { IC: } \\
\text { Preocupação, } \\
\text { medo }\end{array}$ & $\underset{\substack{\text { Preocupação } \\
\text { e medo }}}{\mathbf{F}}$ \\
\hline
\end{tabular}




\begin{tabular}{|c|c|c|c|}
\hline & $\begin{array}{l}\text { [...] Motivo de preocupação, }[\ldots] \text { não } \\
\text { sei se vai ser melhor se a vacina ou } \\
\text { pior, [...] se não se conscientizar não } \\
\text { vai... só ela não... É um motivo de } \\
\text { preocupação porque nós da saúdde } \\
\text { temos a consciência, e às vezes não } \\
\text { fazemos tudo certo, mas nós pelo } \\
\text { menos tamo vendo, e quem não tá } \\
\text { vendo, sofreu a doença e não, e não } \\
\text { vai fazer nada, não vamo conseguir } \\
\text { mudar, entendeu? Mas muita } \\
\text { preocupação. Porque se esse ano foi } \\
\text { desse jeito, imagina o que pode ser o } \\
\text { ano que vem. E não acabou, um caso } \\
\text { ainda aparece, não tem fim. }\end{array}$ & & \\
\hline $\begin{array}{l}\text { HPSH017b } \\
\text { APS }\end{array}$ & $\begin{array}{l}\text { Eu diria que a Dengue é uma } \\
\text { consequência do mal, da mal } \\
\text { educação da população. [...] É... tudo } \\
\text { consequência do desenvolvimento } \\
\text { nosso mesmo, precário. [...] É a } \\
\text { consequência da má educação, dos } \\
\text { maus hábitos, do não treinamento né, } \\
\text { ou do treinamento precário, ou da } \\
\text { falta de consciência, é isso. [...] Esses } \\
\text { terrenos abandonados. Do lado da } \\
\text { minha casa eu já fiz inúmeras } \\
\text { denúncias pra prefeitura, a prefeitura } \\
\text { notifica o dono do terreno, ele vai lá, } \\
\text { da uma limpadinha... }\end{array}$ & $\begin{array}{l}\text { IC: } \\
\text { Consequência } \\
\text { da má educação }\end{array}$ & $\begin{array}{l}\text { D } \\
\text { Consequência } \\
\text { da falta de } \\
\text { educaçăa }\end{array}$ \\
\hline
\end{tabular}




\begin{tabular}{|c|c|c|c|}
\hline IAD1-2 & \multicolumn{3}{|c|}{$\begin{array}{l}\text { Instrumento de Análise do Discurso 1: } \\
\text { Pergunta 2: Se essa mesma pessoa Ihe perguntasse ainda: "Para você, o que } \\
\text { dificulta o controle da Dengue?" O que você lhe diria? }\end{array}$} \\
\hline Entrevistado & Expressões Chave & Ideias Centrais & $\begin{array}{l}\text { Agrupa- } \\
\text { mento }\end{array}$ \\
\hline $\begin{array}{l}\text { HPSH001b } \\
\text { CPA }\end{array}$ & $\begin{array}{l}\text { [...] Eu vou falar pra ela que o que } \\
\text { dificulta o controle da Dengue é a alta } \\
\text { proliferação do mosquitinho... [...] Eu } \\
\text { não sei nem se não quer cuidar, mas } \\
\text { a dificuldade que é isso. Porque não é } \\
\text { fácil! [...] Essa questão do mosquito } \\
\text { mesmo. Da dificuldade de você } \\
\text { localizar, [...] tem muito foco. E todo } \\
\text { mundo tem vasilha em casa, por mais } \\
\text { que cuide. [...] esses reservatórios de } \\
\text { água que todo mundo tá acumulando, } \\
\text { guardando a água, eu diria que mais } \\
\text { por isso mesmo. [...] Porque o } \\
\text { bichinho é safado! Acho que tem que } \\
\text { acabar com o mosquito mesmo pra } \\
\text { acabar com a doença [...] não tem } \\
\text { outro jeito. É a questão do mosquito } \\
\text { se proliferar facilmente em água e ter } \\
\text { muito foco, uma quantidade grande de } \\
\text { foco. }\end{array}$ & $\begin{array}{l}1^{\text {a }} \quad \text { IC: } \\
\text { proliferação do } \\
\text { mosquito }\end{array}$ & $\begin{array}{c}\text { Muitas } \\
\text { Muestôes }\end{array}$ \\
\hline $\begin{array}{l}\text { HPSH002b } \\
\text { DMG }\end{array}$ & $\begin{array}{l}\text { [...] Acho que a população dificulta! E } \\
\text { não é falta de conhecimento não, } \\
\text { porque a mídia tá aí, nós estamos } \\
\text { aqui, têm os profissionais. Eu acho } \\
\text { que é descuido mesmo. [...] Não é } \\
\text { que eles não têm noção, que eles } \\
\text { têm, eu acho que é mais descuido } \\
\text { mesmo; eles não têm a } \\
\text { conscientização, o mal que pode tá } \\
\text { trazendo. [...] Seria a população } \\
\text { mesmo... eles dificultam. }\end{array}$ & IC: A população & $\begin{array}{c}\text { A } \\
\text { Falta de } \\
\text { conscientiza- } \\
\text { ção da } \\
\text { população }\end{array}$ \\
\hline $\begin{array}{l}\text { HPSH003b } \\
\text { FAP }\end{array}$ & $\begin{array}{l}\text { O que dificulta é a população, o } \\
\text { entendimento da população. Quando } \\
\text { você vai orientar "ah, eu já sei disso, } \\
\text { não sei o que", mas como que tá } \\
\text { tendo Dengue lá se ela já sabe de } \\
\text { tudo que a gente orienta, entendeu? } \\
\text { Então o maior problema é a } \\
\text { conscientização da população. Acho }\end{array}$ & $\begin{array}{l}\text { IC: Falta de } \\
\text { entendimento da } \\
\text { população }\end{array}$ & $\begin{array}{c}\text { A } \\
\text { Falta de } \\
\text { conscientiza- } \\
\text { ção da } \\
\text { população }\end{array}$ \\
\hline
\end{tabular}




\begin{tabular}{|c|c|c|c|}
\hline & $\begin{array}{l}\text { que enquanto não começar montar } \\
\text { mesmo, ter as coisas mais forte, não } \\
\text { vai acabar. Uma pena mesmo. [...] } \\
\text { Agora enquanto ficar só esses } \\
\text { agentes endêmicos indo de casa em } \\
\text { casa só falando, muitos nem abrem a } \\
\text { porta, entendeu? É um trabalho difícil, } \\
\text { acho que falta é educação da } \\
\text { população, a população não é } \\
\text { educada. Conscientização mesmo. A } \\
\text { falta de aderência da população né, } \\
\text { comprometimento mesmo com a } \\
\text { doença, né? }\end{array}$ & & \\
\hline $\begin{array}{l}\text { HPSH004b } \\
\text { ECLF }\end{array}$ & $\begin{array}{l}\text { A população. A gente até orienta, } \\
\text { mas, infelizmente cê vê que tem } \\
\text { muito entulho dentro de casa, os } \\
\text { vasos de planta, né, as calhas } \\
\text { d'águas, a caixa d'água, essas cosias } \\
\text { simplezinhas, que poderiam ser } \\
\text { tratadas, e ficam preocupados com a } \\
\text { piscina do vizinho, que tá lá com } \\
\text { cloro, tá sujo, mas tá com cloro, e } \\
\text { esquece que dentro da minha casa } \\
\text { também tem esse risco. Eu acho que } \\
\text { a maioria da preocupação assim } \\
\text { nossa, a dificuldade mesmo é a } \\
\text { conscientização da população. Até } \\
\text { mesmo sendo profissional de saúde } \\
\text { mesmo, ele fica descrente: "ah, vou } \\
\text { orientar as mesmas coisas". Talvez } \\
\text { até dentro da minha casa tenha, eu tô } \\
\text { orientando e não tô fazendo. Então } \\
\text { assim, eu entro na população, todos } \\
\text { nós entramos, acho que é um } \\
\text { descaso nosso mesmo. }\end{array}$ & $\begin{array}{l}\text { IC: Falta de } \\
\text { conscientização } \\
\text { da população }\end{array}$ & $\begin{array}{c}\text { A } \\
\text { Falta de } \\
\text { conscientiza- } \\
\text { ção da } \\
\text { população }\end{array}$ \\
\hline $\begin{array}{l}\text { HPSH005b } \\
\text { RCS }\end{array}$ & $\begin{array}{l}\text { É a dificuldade de conscientização da } \\
\text { pessoa. Conscientizar as pessoas } \\
\text { dos danos, porque a gente tem que } \\
\text { trabalhar muito com prevenção de } \\
\text { danos. [...] E partir do momento que } \\
\text { um indivíduo adoece, ele causa uma } \\
\text { série de danos não só pra ele, mas } \\
\text { pra todo o meio que ele vive. Então a } \\
\text { gente tem que trabalhar a } \\
\text { conscientização, a educação e a } \\
\text { prevenção. [...] A partir do momento } \\
\text { que você educa, você previne danos. } \\
\text { A conscientizacãa e a educação das }\end{array}$ & $\begin{array}{l}\text { IC: Dificuldade } \\
\text { de } \\
\text { conscientização } \\
\text { da pessoa }\end{array}$ & $\begin{array}{c}\text { A } \\
\text { Falta de } \\
\text { conscientiza- } \\
\text { ção da } \\
\text { população }\end{array}$ \\
\hline
\end{tabular}




\begin{tabular}{|c|c|c|c|}
\hline & pessoas, a falta de conscientização. & & \\
\hline $\begin{array}{l}\text { HPSH006b } \\
\text { APOG }\end{array}$ & $\begin{array}{l}\text { [...] A falta de conscientização das } \\
\text { pessoas. É... muitas pessoas } \\
\text { preocupam né, mas tem outras } \\
\text { pessoas que não ligam, que mantém } \\
\text { as casas assim todas mal arrumadas, } \\
\text { não cuidam das casas, o que } \\
\text { prejudica muito a população. [...] Acho } \\
\text { que o que dificulta é isso, porque } \\
\text { informação a gente [...] tá } \\
\text { aumentando, [...] tá correndo bem, a } \\
\text { gente tá informando, fazendo } \\
\text { panfletos, fazendo trabalho com eles, } \\
\text { mas é eu acho mais falta de } \\
\text { conscientização das pessoas. }\end{array}$ & $\begin{array}{l}\text { IC: Falta de } \\
\text { conscientização } \\
\text { das pessoas }\end{array}$ & $\begin{array}{c}\text { A } \\
\text { Falta de } \\
\text { conscientiza- } \\
\text { cáa da } \\
\text { populaçăo }\end{array}$ \\
\hline $\begin{array}{l}\text { HPSH007b } \\
\text { WMS }\end{array}$ & $\begin{array}{l}{[\ldots] \text { Eu acho que o que atrapalha }} \\
\text { bastante é a população, a a } \\
\text { conscientização da população, } \\
\text { porque a gente ainda vê muito é falta } \\
\text { de cuidado com o domicílio, com } \\
\text { terrenos baldios, entendeu? E tem } \\
\text { alguns terrenos que são } \\
\text { abandonados que ficam por conta da } \\
\text { prefeitura, mas tem muitos que são } \\
\text { aqueles terrenos fechados, murados, } \\
\text { que não tem como a gente fazer } \\
\text { muita coisa. Que cada proprietário } \\
\text { tem que assumir sua } \\
\text { responsabilidade. E gente vê muito, } \\
\text { quando a gente sai pra fazer uma } \\
\text { campanha, o que a gente vê de } \\
\text { terreno sujo, com coisas jogadas, } \\
\text { entendeu? E muitos casos que } \\
\text { acontece às vezes, eu na minha casa } \\
\text { tive Dengue, mas eu cuido da minha } \\
\text { casa, mas meu vizinho não cuida, } \\
\text { então eu pego por causa do vizinho. } \\
\text { Enquanto não tiver essa } \\
\text { conscientização mesmo da população } \\
\text { no geral, é um predominante que } \\
\text { dificulta muito o controle da Dengue. } \\
\text { Porque se cada um fizesse, eu fico } \\
\text { imaginando gente, se cada um } \\
\text { tivesse seu terreno bonitinho, } \\
\text { limpinho, da onde que a gente vai } \\
\text { criar Dengue? [...] Não vai ter }\end{array}$ & $\begin{array}{l}\text { IC: Falta da } \\
\text { conscientização } \\
\text { da população }\end{array}$ & $\begin{array}{c}\text { A } \\
\text { Falta de } \\
\text { conscientiza- } \\
\text { caáda da } \\
\text { populaçâao }\end{array}$ \\
\hline
\end{tabular}




\begin{tabular}{|c|c|c|c|}
\hline & $\begin{array}{l}\text { criadouro, então pra mim isso é } \\
\text { primordial! Aí eu acredito que esse } \\
\text { ano se trabalhou bastante a } \\
\text { divulgação, entendeu? Essa } \\
\text { conscientização, porque isso também } \\
\text { é um trabalho de formiguinha, você } \\
\text { tem que persistir, persistir, persistir, e } \\
\text { vai continuar o resto da vida esse } \\
\text { trabalho. Até as pessoas conseguirem } \\
\text { entender que é dessa forma que a } \\
\text { gente vai erradicar. }\end{array}$ & & \\
\hline $\begin{array}{l}\text { HPSH008b } \\
\text { AAS }\end{array}$ & $\begin{array}{l}\text { O que dificulta o controle da Dengue } \\
\text { é, eu acredito que é a resistência das } \\
\text { pessoas em cuidar do seu pedaço, da } \\
\text { sua casa. É de ouvir as orientações } \\
\text { que são dadas através da televisão, } \\
\text { através dos agentes, né, que fazem a } \\
\text { visita em casa, dos agente de } \\
\text { endemias, e só que eu acho que cada } \\
\text { um acha que eles não vão ter, né? } \\
\text { Que o meu vizinho vai ter e eu não } \\
\text { vou ter, então acho que isso dificulta, } \\
\text { essa conscientização mesmo, de } \\
\text { cada um. Isso que eu acho. }\end{array}$ & $\begin{array}{l}\text { IC: Resistência } \\
\text { das pessoas }\end{array}$ & $\begin{array}{c}\text { B } \\
\text { Resistência } \\
\text { e falta de } \\
\text { responsabili- } \\
\text { dade das } \\
\text { pessoas }\end{array}$ \\
\hline \multirow[t]{2}{*}{$\begin{array}{l}\text { HPSH009b } \\
\text { AS }\end{array}$} & $\begin{array}{l}\text { É, por mais que tenha } \\
\text { conscientização da população, ainda } \\
\text { falta... porque eu posso morar num } \\
\text { bairro bom que eu tô bem protegida, } \\
\text { que não tá tendo caso, e tem um } \\
\text { terreno que tá em situação, a pessoa } \\
\text { não se conscientiza que ela tem } \\
\text { responsabilidade sobre aquele local, } \\
\text { sabe? [...] Então, eu acho que tem } \\
\text { que pensar também naquele pessoal } \\
\text { que tá vivendo lá do lado. }\end{array}$ & $\begin{array}{l}\text { 1a IC: Falta de } \\
\text { conscientização } \\
\text { da população }\end{array}$ & $\begin{array}{c}\text { A } \\
\text { Falta de } \\
\text { conscientiza- } \\
\text { ção da } \\
\text { população }\end{array}$ \\
\hline & $\begin{array}{l}\text { [...] Eu não sei porque que [...] teve } \\
\text { esse número elevado de casos. A } \\
\text { epidemiologia, o pessoal que passa } \\
\text { não me apresentou nada; se fizeram } \\
\text { estudo, se já chegaram a alguma } \\
\text { conclusão. [...] O que dificulta o } \\
\text { controle eu acho que é o } \\
\text { levantamento do que que tá } \\
\text { causando, tendeu? [...] que que } \\
\text { dificultou o controle daqui? [...] Qual } \\
\text { que é a justificativa da epidemiologia, }\end{array}$ & $\begin{array}{l}2^{\underline{a}} \text { IC: Não saber } \\
\text { a causa }\end{array}$ & $\begin{array}{c}\text { C } \\
\text { Muitas } \\
\text { questões }\end{array}$ \\
\hline
\end{tabular}




\begin{tabular}{|c|c|c|c|}
\hline & $\begin{array}{l}\text { do pessoal que tá fazendo as visitas... } \\
\text { [...] Eles encontraram o que, mais o } \\
\text { que nas casas? É onde que tá o } \\
\text { maior foco? Por quê? Eu não tive... } \\
\text { então, o que dificulta o controle é o } \\
\text { que você tem que saber a causa pra } \\
\text { poder combater. [...] Porque assim, cê } \\
\text { fica sabendo o quê? Pra controlar cê } \\
\text { não pode deixar água parada, que } \\
\text { não sei o que... toda essa teoria, mas } \\
\text { e quando encontra um maior número } \\
\text { de casos igual aqui, por quê? [...] } \\
\text { Porque que o mosquito disseminou } \\
\text { tanto aqui? Aí, então o que dificulta o } \\
\text { controle é você (não) saber porque } \\
\text { que tá causando naquele lugar, que } \\
\text { que tá causando o maior número de } \\
\text { casos naquele lugar, e eu não sei o } \\
\text { porquê, eu não sei te falar. [...] Aí, } \\
\text { então o que dificulta o controle é cê } \\
\text { não saber a causa, do que tá, né, o } \\
\text { que que tá causando aquilo. }\end{array}$ & & \\
\hline $\begin{array}{l}\text { HPSH010b } \\
\text { ECPG }\end{array}$ & $\begin{array}{l}\text { A falta de informação, principalmente } \\
\text { relacionado à doença em sí. [...] A } \\
\text { pessoa pensa que é o mosquitinho } \\
\text { que pica e que você vai ter ali uma } \\
\text { dorzinha, mas que é uma coisa } \\
\text { passageira, a pessoa não tem ideia } \\
\text { da complexidade do que a Dengue é } \\
\text { em si. [...] A pessoa ainda não sabe o } \\
\text { que realmente é a Dengue [...] das } \\
\text { consequências, da complexidade que } \\
\text { a doença pode trazer em sí. [...] Eu } \\
\text { acho que a informação em relação a } \\
\text { prevenção, ela tá mais que clara, né? } \\
\text { Ela ficou muito clara! Agora nós vamo } \\
\text { ter que esmiuçar um pouquinho mais, } \\
\text { divulgar mais a doença, o que é a } \\
\text { doença. Eu acredito que, assim, ficou } \\
\text { em cima dos sintomas [...]. }\end{array}$ & $\begin{array}{l}\text { IC: Falta de } \\
\text { informação } \\
\text { sobre a doença } \\
\text { em sí }\end{array}$ & $\begin{array}{c}\text { C } \\
\text { Muitas } \\
\text { questões }\end{array}$ \\
\hline $\begin{array}{l}\text { HPSH011b } \\
\text { VDR }\end{array}$ & $\begin{array}{l}\text { [...] Eu acho que a população, falta de } \\
\text { educação da população. [...] Acho } \\
\text { que a população não colabora. A } \\
\text { gente orienta, orienta, orienta, a } \\
\text { população não colabora, ainda } \\
\text { continua, é... acumulando água, eu } \\
\text { acho que isso ai é responsabilidade } \\
\text { da população. Se tá esse surto, é da }\end{array}$ & $\begin{array}{ll}\text { IC: } \quad \text { Falta } & \text { de } \\
\text { educação } & \text { da } \\
\text { população } & \end{array}$ & $\begin{array}{c}\text { A } \\
\text { Falta de } \\
\text { conscientiza- } \\
\text { ção da } \\
\text { população }\end{array}$ \\
\hline
\end{tabular}




\begin{tabular}{|c|c|c|c|}
\hline & $\begin{array}{l}\text { população! Eu acho isso. Porque eu } \\
\text { acho que o pessoal da saúde orienta } \\
\text { muito, pelo menos aqui no PSF eu } \\
\text { vejo, os agente comunitários, eu, [...] } \\
\text { mas a população acha que isso } \\
\text { nunca vai acontecer com ele. Então, é } \\
\text { isso. }\end{array}$ & & \\
\hline $\begin{array}{l}\text { HPSH012b } \\
\text { NR }\end{array}$ & $\begin{array}{l}\text { [...] Aí vai entrar, acho que em muitas } \\
\text { questões. Vai entrar questão climática } \\
\text { mesmo, sabe, desde o clima, da } \\
\text { região geográfica, até o } \\
\text { comprometimento das pessoas, o } \\
\text { recurso de infraestrutura, o recurso de } \\
\text { recursos humanos pra trabalhar, } \\
\text { envolve tudo isso. Principal acho que } \\
\text { é, conseguir o comprometimento de } \\
\text { todo mundo, porque ele envolve tanto } \\
\text { o profissional que tem que ter recurso } \\
\text { humano, ele tem que ter infraestrutura } \\
\text { pra trabalhar, mas ele envolve outro } \\
\text { lado que é a comunidade, então eu } \\
\text { tenho que trabalhar a cabecinha da } \\
\text { comunidade, e às vezes uma casa faz } \\
\text { certinho e três casas já não adere } \\
\text { aquela orientação que recebeu, então } \\
\text { pra mim o mais difícil é isso. }\end{array}$ & $\begin{array}{l}\text { IC: } \\
\text { questões }\end{array}$ & $\begin{array}{c}\text { C } \\
\text { Muitas } \\
\text { questōes }\end{array}$ \\
\hline $\begin{array}{l}\text { HPSH013b } \\
\text { SMR }\end{array}$ & $\begin{array}{l}{[\ldots] \text { Se cada ser humano [...] }} \\
\text { soubesse a importância de fazer a } \\
\text { prevenção da Dengue, eu acho que } \\
\text { isso ajudaria muito né nesse contexto } \\
\text { todo. O que dificulta, eu acho que não } \\
\text { é a falta de informação, é a falta de } \\
\text { responsabilidade, } \\
\text { responsabilidade como ser humano, } \\
\text { como cidadão, de pensar no próximo, } \\
\text { ser humano, entendeu? A prevenção } \\
\text { mesmo, se cada um cuidasse do seu } \\
\text { local, né, eu acho que isso mudaria } \\
\text { muito. [...] Então, é por aí mesmo. }\end{array}$ & $\begin{array}{l}\text { IC: Falta de } \\
\text { responsabilidade }\end{array}$ & $\begin{array}{c}\text { B } \\
\text { Resistência } \\
\text { e falta de } \\
\text { responsabili- } \\
\text { dade das } \\
\text { pessoas }\end{array}$ \\
\hline $\begin{array}{l}\text { HPSH014b } \\
\text { VLS }\end{array}$ & $\begin{array}{l}\text { Ah, é o vizinho. Eu faço, mas o meu } \\
\text { vizinho não faz. [...] "por que que eu } \\
\text { faço a limpeza da minha casa, eu } \\
\text { cuido da minha casa, e a minha } \\
\text { vizinha não cuida da casa dela?" [...] } \\
\text { "ele não deixa ninguém entrar na } \\
\text { casa dele, nem o pessoal da Dengue } \\
\text { pra fazer o controle da Dengue." Essa }\end{array}$ & $1^{\text {a }}$ IC: $\mathrm{O}$ vizinho & $\begin{array}{c}\text { A } \\
\text { Falta de } \\
\text { conscientiza- } \\
\text { ção da } \\
\text { população }\end{array}$ \\
\hline
\end{tabular}




\begin{tabular}{|c|c|c|c|}
\hline & $\begin{array}{l}\text { foi a maior pergunta que foram feitas } \\
\text { pra mim dos pacientes: "que eu faço } \\
\text { com o meu vizinho?" Porque a } \\
\text { população tem que se conscientizar, } \\
\text { mas não no período da Dengue. } \\
\text { Então, essa preocupação também é } \\
\text { do pessoal da vigilância, que faz as } \\
\text { visitas [...] nas nossas micro áreas, é } \\
\text { o vizinho, que é a preocupação. } \\
\text { Na minha opinião o que dificulta o } \\
\text { controle da Dengue é a } \\
\text { conscientização da população com } \\
\text { relação à gravidade da Dengue. Eu } \\
\text { acho que tem que os meios de } \\
\text { comunicações [...] informar a } \\
\text { população realmente da seriedade da } \\
\text { Dengue. [...] Mas o que mais } \\
\text { compromete a Dengue é o cuidado do } \\
\text { vizinho que não tem cuidado com a } \\
\text { casa, que a população toda não sabe } \\
\text { a gravidade da Dengue; e nós } \\
\text { fizemos panfletagem, nós fizemos } \\
\text { conscientização porta a porta, os } \\
\text { agentes foram em cada área, cada } \\
\text { micro área conscientizar a população, } \\
\text { mas o retorno foi pequeno. }\end{array}$ & $\begin{array}{l}2^{a} \text { IC: Falta de } \\
\text { conscientização } \\
\text { da população } \\
\text { sobre } \\
\text { gravidade da } \\
\text { Dengue }\end{array}$ & $\begin{array}{c}\text { A } \\
\text { Falta de } \\
\text { conscientiza- } \\
\text { ção da } \\
\text { população }\end{array}$ \\
\hline $\begin{array}{l}\text { HPSH015b } \\
\text { DCC }\end{array}$ & $\begin{array}{l}\text { [...] As pessoas se conscientizar que } \\
\text { elas têm que cuidar do seu quintal, } \\
\text { não só do seu quintal, também se ver } \\
\text { alguma coisa errada em um lugar } \\
\text { assim que é foco tem que falar pra } \\
\text { vigilância, é.. deixar os agentes de } \\
\text { endemia entrar, é... O que dificulta é } \\
\text { isso. } \\
\text { E também [...] saiu um boato que } \\
\text { tinha um ladrão vestido de agente de } \\
\text { endemia entrando nas casas, aí eu } \\
\text { acho que isso também, [...] a pessoa } \\
\text { cria resistência e não deixa os } \\
\text { agentes de saúde entrar, causa meio } \\
\text { que medo na população. }\end{array}$ & $\begin{array}{l}\text { 1 }^{\text {a }} \text { IC: Falta de } \\
\text { conscientização } \\
\text { das pessoas }\end{array}$ & $\begin{array}{c}\text { A } \\
\text { Falta de } \\
\text { conscientiza- } \\
\text { ção da } \\
\text { população } \\
\\
\text { C } \\
\text { Muitas } \\
\text { questões }\end{array}$ \\
\hline $\begin{array}{l}\text { HPSH016b } \\
\text { PLG }\end{array}$ & $\begin{array}{l}\text { As pessoas, não tem outra, é } \\
\text { totalmente responsabilidade nossa } \\
{[\ldots] \text { o controle é nosso mesmo, não }} \\
\text { tem outro culpado, somos nós que } \\
\text { somos os culpados. [...] Em alguns }\end{array}$ & IC: As pessoas & $\begin{array}{c}\text { A } \\
\text { Falta de } \\
\text { conscientiza- } \\
\text { ção da } \\
\text { população }\end{array}$ \\
\hline
\end{tabular}




\begin{tabular}{|c|c|c|c|}
\hline & $\begin{array}{l}\text { bairros tem muita oficinas que ficam } \\
\text { abertas aí, a céu aberto, eles } \\
\text { costumam lavar os carros, jogar água } \\
\text { nas mangueiras e ali onde cai aquela } \\
\text { água, não tiram a água. [...] A culpa é } \\
\text { nossa mesmo, não tem outra, o } \\
\text { controle sempre vai ser nosso, e } \\
\text { talvez isso vai dificultar mesmo com } \\
\text { essa vacina, porque eles vão achar } \\
\text { que tão imunizado, vai só piorar. }\end{array}$ & & \\
\hline $\begin{array}{l}\text { HPSH017b } \\
\text { APS }\end{array}$ & $\begin{array}{l}\text { Eu diria que o que dificulta é a } \\
\text { capacitação dos agentes, [...] não é o } \\
\text { número, porque a gente tem um } \\
\text { grande número que daria conta de } \\
\text { manter no mínimo controlado o caso } \\
\text { de Dengue, mas assim, o que dificulta } \\
\text { o treinamento. [...] no caso aqui de } \\
\text { Alfenas, eles já pensam assim, vou } \\
\text { entrar na prefeitura porque } \\
\text { funcionário público não trabalha, aí o } \\
\text { dia que tá com sol quente eles não } \\
\text { saem, dia que chove eles não saem, } \\
\text { já não trabalham, os agentes de } \\
\text { endemias. } \\
\text { E assim, eu acho que falta também, } \\
\text { dos PSFs, mais cobrança em cima } \\
\text { dos agentes de saúde, porque [...] a } \\
\text { visita do agente de saúde não é um } \\
\text { mero: "você tá precisando de alguma } \\
\text { coisa, um médico vai atender tal dia, } \\
\text { né?" Acho que mais uma educação } \\
\text { permanente do que uma continuada. }\end{array}$ & $\begin{array}{l}\text { 1. } \\
\text { Capacitação dos } \\
\text { ACE } \\
\\
2^{\text {a }} \text { IC: Falta de } \\
\text { mais cobrança } \\
\text { dos ACS }\end{array}$ & $\begin{array}{c}\text { Muitas } \\
\text { questôes }\end{array}$ \\
\hline
\end{tabular}




\begin{tabular}{|c|c|c|c|}
\hline IAD1-3 & \multicolumn{3}{|c|}{$\begin{array}{l}\text { Instrumento de Análise do Discurso 1: } \\
\text { Pergunta 3: Para você, o que facilita o controle da Dengue? }\end{array}$} \\
\hline Entrevistado & Expressões Chave & Ideias Centrais & $\begin{array}{l}\text { Agrupa- } \\
\text { mento }\end{array}$ \\
\hline $\begin{array}{l}\text { HPSH001b } \\
\text { CPA }\end{array}$ & $\begin{array}{l}\text { [...] A conscientização ajuda. O } \\
\text { trabalho de educação em saúde } \\
\text { facilita. O governo, quando [...] } \\
\text { começa a fazer propaganda. [...] } \\
\text { Quando a própria vigilância descobre } \\
\text { que tem um foco e vai lá, faz o } \\
\text { trabalho deles... [...] fumacê, eu acho } \\
\text { que ajuda no controle também. } \\
\text { Quando a gente notifica [...] eles ficam } \\
\text { mais atentos, isso também ajuda. [...] } \\
\text { Educação. E eu acho que o trabalho } \\
\text { dos nossos gestores de estar fazendo } \\
\text { a parte deles, de divulgar, de estar } \\
\text { intervindo }[\ldots . .]\end{array}$ & $\begin{array}{l}\text { IC: Diversos } \\
\text { facilitadores }\end{array}$ & $\begin{array}{c}\mathbf{H} \\
\text { Diversos } \\
\text { facilitadores }\end{array}$ \\
\hline $\begin{array}{l}\text { HPSH002b } \\
\text { DMG }\end{array}$ & $\begin{array}{l}\text { Uai, se a população fizesse a parte } \\
\text { dela... [...] A população tem que fazer } \\
\text { a parte dela. [...] Porque eu acho que, } \\
\text { a maioria das coisas, é dentro de casa } \\
\text { que eles acham o foco. [...] Porque a } \\
\text { gente faz a nossa parte profissional, } \\
{[\ldots] \text { as pessoas, elas têm que tornar }} \\
\text { mais responsáveis também pelas } \\
\text { coisas [...]. }\end{array}$ & $\begin{array}{l}\text { IC: A população } \\
\text { fazer a sua parte }\end{array}$ & $\begin{array}{c}\mathbf{H} \\
\text { Diversos } \\
\text { facilitadores }\end{array}$ \\
\hline $\begin{array}{l}\text { HPSH003b } \\
\text { FAP }\end{array}$ & $\begin{array}{l}{[\ldots] \text { Eu acho que um dos maiores }} \\
\text { trabalhos que a gente teve bastante } \\
\text { resultados foi nas escolas. Pegar as } \\
\text { crianças pequenininha pra levar pra } \\
\text { casa como tarefa de orientação. A } \\
\text { própria criança chegar falar assim "ó } \\
\text { mãe, esse vasinho tá errado", } \\
\text { entendeu? Acho que esse foi nosso } \\
\text { maior, que a gente conseguiu mais } \\
\text { resultado. [...] Mas eu acho que tinha } \\
\text { que começar a orientação nas escolas } \\
\text { mesmo. Questão da educação } \\
\text { mesmo, desde pequenininho. } \\
\text { [...] Esse ano também a gente teve } \\
\text { uma parceria muito grande dos } \\
\text { agentes endêmicos, então todo caso }\end{array}$ & $\begin{array}{l}2^{\underline{a}} \text { IC: Parceria } \\
\text { dos agentes } \\
\text { endêmicos }\end{array}$ & $\begin{array}{l}\text { A } \\
\text { Trabalho de de } \\
\text { orientacăo e } \\
\text { conscientiza- } \\
\text { ção }\end{array}$ \\
\hline
\end{tabular}




\begin{tabular}{|c|c|c|c|}
\hline & $\begin{array}{l}\text { que nós notificávamos eles já vinham } \\
\text { na casa fazer [...] a busca, pra ver se } \\
\text { ao redor ali, [...] pra jogar o fumacê, } \\
\text { então isso foi um ponto muito } \\
\text { importante, a população ficou alerta. } \\
\text { [...] Aí começou uma preocupação } \\
\text { maior da população. Isso foi muito } \\
\text { bom. A gente identificava, aí a gente } \\
\text { acionava os agentes endêmicos, os } \\
\text { agentes endêmicos iam lá na casa. Aí } \\
\text { eles faziam um trabalho melhor, } \\
\text { entedeu? } \\
\text { [...]Mas acho que tem que voltar } \\
\text { mesmo pra parte de cobrança, eu não } \\
\text { falo de dinheiro, nem se for serviço } \\
\text { social, alguma coisa, aí a população } \\
\text { vai começar a ver mais, prestar mais } \\
\text { atenção né. }\end{array}$ & 3a IC: Cobrança & $\underset{\substack{\text { Diversos } \\
\text { facilitadores }}}{\mathbf{H}}$ \\
\hline $\begin{array}{l}\text { HPSH004b } \\
\text { ECLF }\end{array}$ & $\begin{array}{l}\text { [...] A gente está tendo um facilitador } \\
\text { muito grande, que é o pessoal do } \\
\text { agente de endemia, eles estão aqui } \\
\text { no PSF, então eles estão passando } \\
\text { na nossa área, isso pra gente tá } \\
\text { facilitando. [...] Onde tem dificuldade } \\
\text { eu pedi pra eles terem um acesso } \\
\text { com o agente comunitário [...], porque } \\
\text { a gente tem essa dificuldade, eles não } \\
\text { estão abrindo, infelizmente, para os } \\
\text { agentes de endemia, tem essa } \\
\text { resistência [...]. A população aqui, por } \\
\text { ser mais instruída, não deixa os } \\
\text { agentes tarem entrando nas suas } \\
\text { casas, mas eles são os facilitadores } \\
\text { para gente. A nossa equipe mesmo } \\
\text { está orientada [...]. A gente } \\
\text { encaminha para a vigilância tomar } \\
\text { uma providência [...]. Aqui também } \\
\text { tem muita gente que não recebe nem } \\
\text { agente comunitário. Mas eu acho que } \\
\text { o facilitador mesmo é essa parceria } \\
\text { que a gente tem com o pessoal do } \\
\text { agente de endemia. Eles estão } \\
\text { sempre atualizando a gente [...], acho } \\
\text { que isso que está ajudando. }\end{array}$ & $\begin{array}{ll}\text { IC: Parceria com } \\
\text { o pessoal do } \\
\text { agente } & \text { de } \\
\text { endemia } & \end{array}$ & $\underset{\text { Parcerias }}{\mathbf{E}}$ \\
\hline
\end{tabular}




\begin{tabular}{|c|c|c|c|}
\hline $\begin{array}{l}\text { HPSH005b } \\
\text { RCS }\end{array}$ & $\begin{array}{l}{[\ldots] \text { Eu acho que assim, o que }} \\
\text { facilitaria, a população ter a noção da } \\
\text { gravidade da doença, e trabalhar } \\
\text { como agentes disseminadores do } \\
\text { conhecimento. [...] Então, o que } \\
\text { facilitaria seria a educação da } \\
\text { população. [...] Então eu acho que } \\
\text { assim, que infelizmente as pessoas } \\
\text { chega a essa conclusão a partir do } \\
\text { momento que elas passam por esse } \\
\text { né, passa pela dor. [...] Enquanto você } \\
\text { está falando, ninguém quer } \\
\text { conscientizar, mas a partir do } \\
\text { momento que afeta... [...] Então quer } \\
\text { dizer, nós somos muito mal educados. } \\
\text { [...] Gente, a educação ambiental pelo } \\
\text { amor de Deus! Você está agredindo a } \\
\text { natureza, você passa perto de um rio, } \\
\text { o rio tá cheio, entulhado de lixo, } \\
\text { transbordando. Então, eu acho que a } \\
\text { Dengue, ela custou muito pra aflorar, } \\
\text { só que a Dengue não vai servir pra } \\
\text { barrar essa falta de educação. [...] } \\
\text { Cada vez mais, nós estamos } \\
\text { produzindo mais resíduos, estamos } \\
\text { produzindo mais lixos, estamos } \\
\text { ficando mais desorganizados, mais } \\
\text { mal educados. }\end{array}$ & $\begin{array}{l}\text { IC: Educação da } \\
\text { população }\end{array}$ & $\begin{array}{c}\text { B } \\
\begin{array}{c}\text { Educação da } \\
\text { população }\end{array}\end{array}$ \\
\hline $\begin{array}{l}\text { HPSH006b } \\
\text { APOG }\end{array}$ & $\begin{array}{l}\text { [...] Então, essas propagandas, } \\
\text { panfletos, [...] conscientização que as } \\
\text { pessoas, [...] principalmente dessas } \\
\text { unidades de saúde, a gente tá } \\
\text { conscientizando as pessoas, isso } \\
\text { facilita pra ter um controle melhor. } \\
\text { Porque [...] a partir do momento que } \\
\text { começa a passar na televisão, [...] } \\
\text { entregar panfletos, as pessoas estão } \\
\text { vendo quais são [...] os sintomas, já } \\
\text { estão correndo atrás né, [...] se } \\
\text { informando melhor, já ficam } \\
\text { preocupadas. }\end{array}$ & $\begin{array}{l}\text { IC: } \\
\text { Conscientização } \\
\text { das pessoas }\end{array}$ & $\begin{array}{c}\text { A } \\
\text { Trabalho de } \\
\text { orientação e } \\
\text { conscientiza- } \\
\text { ção }\end{array}$ \\
\hline $\begin{array}{l}\text { HPSH007b } \\
\text { WMS }\end{array}$ & $\begin{array}{l}\text { O que facilita, o que pode colaborar é } \\
\text { realmente o trabalho de } \\
\text { conscientização, que a gente está } \\
\text { fazendo. [...] Usar bastante mesmo o } \\
\text { que a gente tem hoje em dia: as redes } \\
\text { sociais, a mídia, a maioria... [...] tem } \\
\text { acesso. Então eu acho que isso é }\end{array}$ & $\begin{array}{l}\text { IC: Trabalho de } \\
\text { conscientização }\end{array}$ & $\begin{array}{c}\text { A } \\
\text { Trabalho de } \\
\text { orientação e } \\
\text { conscientiza- } \\
\text { ção }\end{array}$ \\
\hline
\end{tabular}




\begin{tabular}{|c|c|c|c|}
\hline & $\begin{array}{l}\text { uma coisa que pode facilitar muito, } \\
\text { entendeu? De você usar mesmo } \\
\text { desses meios pra tá divulgando, pra } \\
\text { trabalhar essa conscientização. [...] } \\
\text { Uma hora as pessoas vão conseguir } \\
\text { entender que se cada dia eu } \\
\text { conseguir conscientizar uma pessoa, } \\
\text { através desses meios [...] um rádio, } \\
\text { uma televisão, celular [...] com } \\
\text { Facebook. [...] Eu acho que é uma } \\
\text { opção, que realmente o pessoal até } \\
\text { usou bastante, Facebook, pra divulgar } \\
\text { mensagem de campanha contra a } \\
\text { Dengue. E não deixando de lado, } \\
\text { claro que não, a tet-a-tet né, casa-a- } \\
\text { casa, as palestras em sí tem que } \\
\text { existir, mas estar usando também } \\
\text { esses meios de comunicação que } \\
\text { ajuda muito, facilita muito se a gente } \\
\text { souber usar. }\end{array}$ & & \\
\hline $\begin{array}{l}\text { HPSH008b } \\
\text { AAS }\end{array}$ & $\begin{array}{l}{[\ldots] \dot{E} \text { o pessoal não desistir de }} \\
\text { trabalhar nas orientações, né? Isso } \\
\text { facilita assim que tem os profissionais, } \\
\text { têm os agentes que tão todos os dias } \\
\text { fazendo as mesmas orientações, [...] } \\
\text { ajudas, parcerias em orientação. } \\
\text { Então isso pra mim é uma facilidade, } \\
\text { é o que facilita o controle. }\end{array}$ & $\begin{array}{l}\text { IC: Trabalho de } \\
\text { orientação }\end{array}$ & $\begin{array}{l}\text { A } \\
\text { Trabalho de } \\
\text { orientação e } \\
\text { conscientiza- } \\
\text { ção }\end{array}$ \\
\hline $\begin{array}{l}\text { HPSH009b } \\
\text { AS }\end{array}$ & $\begin{array}{l}\text { Já está visto que a gente tem que } \\
\text { combater o mosquito, tem que } \\
\text { combater a proliferação dele, então } \\
{[\ldots] \text { eu acho que o caminho é esse }} \\
\text { mesmo, que vai facilitar é combater. } \\
{[\ldots] \text { Fazendo aquelas velhas condutas }} \\
{[\ldots] \text {. De não deixar água parada, de }} \\
\text { olhar as plantas [...] e continuar com } \\
\text { essas outras experiências pra gente } \\
\text { ver se dá certo [...] se esses } \\
\text { predadores derem certo, vamos pôr } \\
\text { os predadores. Aquele fumacê [...]. Eu } \\
\text { acho que é investir em experiências, } \\
\text { investir em vacina, o caminho vai ser } \\
\text { esse mesmo. }\end{array}$ & $\begin{array}{l}\text { 1ㄹ IC: Combater } \\
\text { o mosquito }\end{array}$ & $\begin{array}{c}\text { D } \\
\begin{array}{c}\text { Saneamento } \\
\text { básico }\end{array}\end{array}$ \\
\hline & $\begin{array}{l}\text { E melhorar a questão de saneamento } \\
\text { básico, já que eu acho que o } \\
\text { problema maior é o saneamento; } \\
\text { porque é uma doença muito primária, }\end{array}$ & $\begin{array}{l}\text { 2a IC: Melhorar o } \\
\text { saneamento } \\
\text { básico }\end{array}$ & $\begin{array}{l}\text { D } \\
\text { Saneamento } \\
\text { básico }\end{array}$ \\
\hline
\end{tabular}




\begin{tabular}{|c|c|c|c|}
\hline & $\begin{array}{l}\text { uma coisa muito básica [...]. Tem que } \\
\text { acabar, não pode continuar. }\end{array}$ & & \\
\hline $\begin{array}{l}\text { HPSH010b } \\
\text { ECPG }\end{array}$ & $\begin{array}{l}\text { O que facilita é essa quantidade de } \\
\text { informação, eu acho que hoje em dia } \\
\text { qualquer lugar que você for, você tiver } \\
\text { num mercado você vai achar um } \\
\text { cartazinho falando. Pelo menos a } \\
\text { gente pregou cartaz em tudo quanto } \\
\text { que foi estabelecimento, então, as } \\
\text { informações estão ali muito presentes, } \\
\text { tanto na internet, a televisão, então } \\
\text { assim, as informações elas são o que } \\
\text { facilitam. }\end{array}$ & $\begin{array}{l}\text { IC: Quantidade } \\
\text { de informação }\end{array}$ & $\underset{\text { Informaçöes }}{\mathbf{G}}$ \\
\hline $\begin{array}{l}\text { HPSH011b } \\
\text { VDR }\end{array}$ & $\begin{array}{l}\text { E... não deixar água acumulada, lixo } \\
\text { acumulado também, e educação. } \\
\text { Acho que tá tudo baseado na } \\
\text { educação da pessoa, conhecimento } \\
\text { da pessoa, eu acho isso. Acho que o } \\
\text { conhecimento, a educação, se todo } \\
\text { mundo tivesse como deveria ter, eu } \\
\text { acho que estaria tudo certo. Acho que } \\
\text { o povo precisa ser mais educado. Em } \\
\text { geral, né? Principalmente a } \\
\text { população. Acho que isso tudo tá } \\
\text { relacionado com educação, acho que } \\
\text { toda saúde da pessoa está } \\
\text { relacionada com educação. Eu acho } \\
\text { isso. }\end{array}$ & IC: Educação & $\begin{array}{c}\text { B } \\
\text { Educação da } \\
\text { populaçăão }\end{array}$ \\
\hline $\begin{array}{l}\text { HPSH012b } \\
\text { NR }\end{array}$ & $\begin{array}{l}\dot{E} \text {, união de forças, né? [...] Nós } \\
\text { vamos somar aí todo mundo junto, aí } \\
\text { eu acho que isso facilita. Que nem } \\
\text { aqui, o agente de saúde está junto } \\
\text { com o agente da endemia, porque aí } \\
\text { o agente de saúde também está na } \\
\text { casa, e aí eu acho que isso facilita. } \\
\text { [...] Você vê que quando unem forças, } \\
\text { o resultado é mais rápido, mais eficaz. } \\
\text { [...] Então, Alfenas tem que trabalhar } \\
\text { mais, nós temos, porque eu faço } \\
\text { parte. }\end{array}$ & $\begin{array}{l}\text { IC: União de } \\
\text { forças }\end{array}$ & $\begin{array}{c}\mathbf{E} \\
\text { Parcerias }\end{array}$ \\
\hline $\begin{array}{l}\text { HPSH013b } \\
\text { SMR }\end{array}$ & $\begin{array}{l}\text { O que facilita? [...] É a consciência de } \\
\text { cada um. Eu acho assim propaganda } \\
\text { existe [...] está na mídia. Cartazes } \\
\text { existem pra todo lado, o agente } \\
\text { comunitário trabalha nessa própria }\end{array}$ & $\begin{array}{l}\text { IC: Consciência } \\
\text { de cada um }\end{array}$ & $\begin{array}{c}\text { C } \\
\text { Consciência } \\
\text { das pessoas }\end{array}$ \\
\hline
\end{tabular}




\begin{tabular}{|c|c|c|c|}
\hline & 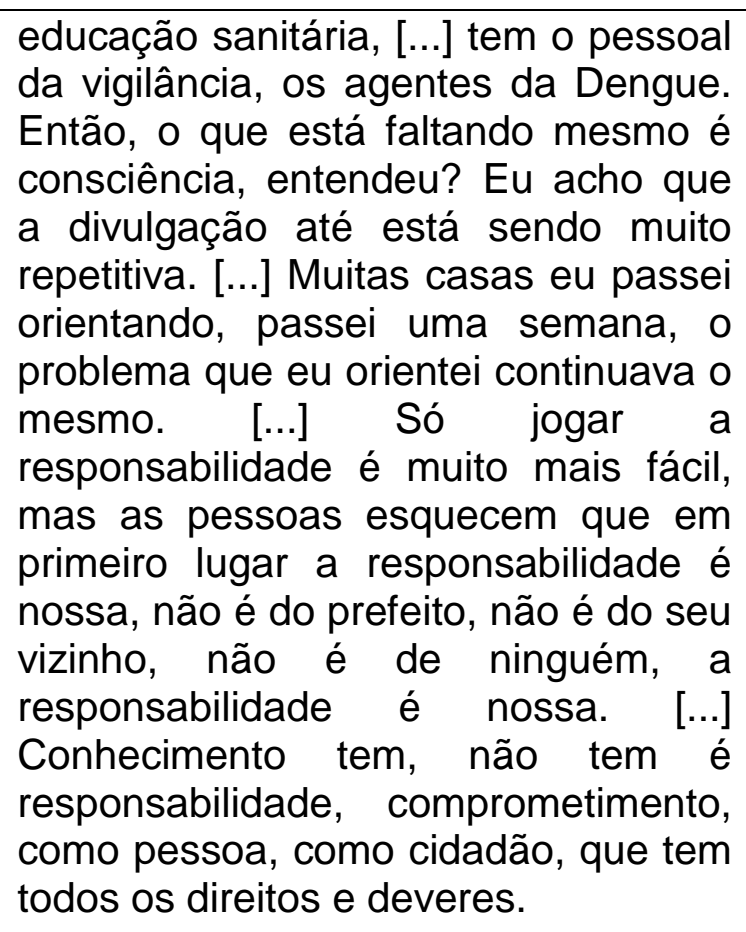 & & \\
\hline $\begin{array}{l}\text { HPSH014b } \\
\text { VLS }\end{array}$ & $\begin{array}{l}\text { O que facilita pra mim é a } \\
\text { conscientização, [...] } \\
\text { conscientização da população. } \\
\text { Utilização de meios de informação pra } \\
\text { população, eu acho que usaram } \\
\text { muito, a Dengue já instalada, a } \\
\text { Dengue atuando, a população } \\
\text { sofrendo com a Dengue, eu acho que } \\
\text { deveria ter feito isso a nível } \\
\text { preventivo. É: "nós vamos estar numa } \\
\text { época de Dengue? Vamos, mas } \\
\text { vamos fazer uma prevenção antes!" } \\
\text { Usar os meios de comunicação e } \\
\text { informar a população sobre a Dengue, } \\
\text { quais os sintomas... Porque ninguém } \\
\text { sabe a gravidade da Dengue, só nós } \\
\text { da saúde que sabemos a gravidade } \\
\text { da Dengue. E esse ano posso garantir } \\
\text { pra você que foi bem pior, bem pior. } \\
\text { [...] E a população, vou dizer a } \\
\text { verdade pra você, a população não se } \\
\text { importou com a Dengue, não se } \\
\text { importou. E é grave. Porque a } \\
\text { população tem que se conscientizar, } \\
\text { tem que querer fazer a parte } \\
\text { preventiva. Se eu chegar numa casa } \\
\text { que tem um monte de entulhos e } \\
\text { conscientizar esse indivíduo, a } \\
\text { Dengue, os cuidados com a Dengue, } \\
\text { ele fala que não existe isso não. E }\end{array}$ & $\begin{array}{l}\text { IC: } \\
\text { Conscientização } \\
\text { da população }\end{array}$ & $\begin{array}{c}\mathbf{C} \\
\text { Consciência } \\
\text { das pessoas }\end{array}$ \\
\hline
\end{tabular}




\begin{tabular}{|c|c|c|c|}
\hline & $\begin{array}{l}\text { amanhã o vizinho do lado aparece } \\
\text { aqui com os sintomas da Dengue: "foi } \\
\text { aquele meu vizinho hein, vocês foram } \\
\text { lá fazer visita, mas ele não quis limpar } \\
\text { a casa não, a casa está lá suja do } \\
\text { mesmo jeito..." [...] Uma questão } \\
\text { cultural talvez, né? }\end{array}$ & & \\
\hline $\begin{array}{l}\text { HPSH015b } \\
\text { DCC }\end{array}$ & $\begin{array}{l}\text { [...] Pra mim eu acho que são essas } \\
\text { divulgações, na televisão, } \\
\text { panfletagem, o próprio agente de } \\
\text { endemia, o PSF, com os agentes de } \\
\text { saúde é orientando nas casas. }\end{array}$ & IC: Divulgações & $\begin{array}{c}\mathbf{G} \\
\text { IInormaçōes }\end{array}$ \\
\hline $\begin{array}{l}\text { HPSH016b } \\
\text { PLG }\end{array}$ & $\begin{array}{l}\text { Eu nem diria assim que facilita, }[\ldots] \\
\text { gente teve um bom resultado porque } \\
\text { dessa vez eu consegui ver os meus } \\
\text { pacientes de perto que estavam com } \\
\text { Dengue. Porque o hospital bloqueou } \\
\text { lá }[\ldots . .] \text { não atendeu e jogou aqui e } \\
\text { acabou que a gente assistiu mais, e } \\
\text { das outras vezes como eram poucos } \\
\text { casos nós não tivemos essa visão. [...] } \\
\text { Agora dessa vez foi assustador [...]. } \\
\text { Então eu não vejo nem o que facilitou, } \\
\text { eu achei assim que a Dengue dessa } \\
\text { vez ajudou nós enxergarmos melhor } \\
\text { os nossos pacientes. }\end{array}$ & $\begin{array}{l}\text { IC: Não há } \\
\text { facilitadores }\end{array}$ & $\begin{array}{c}\mathbf{F} \\
\text { Não há } \\
\text { facilitadores }\end{array}$ \\
\hline $\begin{array}{l}\text { HPSH017b } \\
\text { APS }\end{array}$ & $\begin{array}{l}\text { Eu acho que o que facilita é a gente tá } \\
\text { capacitando melhor os agentes, [...] e } \\
\text { remuneradamente também, eu acho } \\
\text { que é o que ajuda. Porque se ele é } \\
\text { bem pago, ele vai querer trabalhar pra } \\
\text { ver o resultado. [...] Acho que se eles } \\
\text { tivessem um incentivo maior, [...] } \\
\text { financeiramente, [...] ajudaria, porque } \\
\text { eles iam trabalhar em cima de } \\
\text { produção, e isso ia diminuir os casos } \\
\text { também de Dengue. }\end{array}$ & $\begin{array}{l}\text { IC: Capacitar e } \\
\text { remunerar } \\
\text { melhor os ACE }\end{array}$ & $\begin{array}{c}\mathbf{H} \\
\text { Diversos } \\
\text { facilitadores }\end{array}$ \\
\hline
\end{tabular}




\section{ANEXO E - Instrumento de Análise do Discurso 2 - IAD2}

\begin{tabular}{|l|l|}
\hline IAD2-1 & $\begin{array}{l}\text { Instrumento de Análise do Discurso 2: } \\
\text { Pergunta 1: Se uma amiga Ihe perguntasse o que a Dengue significa para você, } \\
\text { qual seria a sua resposta? }\end{array}$ \\
\hline
\end{tabular}

\begin{tabular}{|l|l|}
\hline \multicolumn{1}{|c|}{$\begin{array}{l}\text { A } \\
\text { Desconforto enorme }\end{array}$} \\
\hline Entrevistado & \multicolumn{1}{|c|}{ Expressões Chave } \\
\hline HPSH001b \\
CPA & $\begin{array}{l}\text { [...] Nossa, eu acho que é um período curto, mas é muito ruim. Eu } \\
\text { tive Dengue, e foi bem leve, foi horrível. E todo mundo comenta que } \\
\text { não é nada bom, é pior que você ter um resfriado. É... eu não } \\
\text { gostaria de ter não. [...] Uma coisa muito incômoda, muito chata } \\
\text { mesmo pra mim. Não é coisa de outro mundo não porque ela veio, } \\
\text { do mesmo jeito que veio foi embora, né? Foi rápido, não foi } \\
\text { complicado nem nada. Olha, você se sente mal o tempo todo, cê se } \\
\text { sente enfraquecido, você não consegue fazer, desenvolver nada. } \\
\text { Cê levanta, suas pernas ficam bambas, né? No caso, as pessoas } \\
\text { relatam muita dor de cabeça, eu tive pouco episódio. [...] Dor no } \\
\text { corpo, a dor na cabeça que não foi muito, dor no olho, né? Depois } \\
\text { fiquei toda coçando, né? Tive enjoo, vômito, a boca amarga. [...] } \\
\text { Mas foi isso que eu senti. }\end{array}$ \\
\hline HPSH013b \\
SMR
\end{tabular}




\begin{tabular}{|l|l|}
\hline \multicolumn{1}{|c|}{ B } \\
\hline Entreblema de saúde pública
\end{tabular}




\begin{tabular}{|c|c|}
\hline \multicolumn{2}{|r|}{$\begin{array}{c}\text { C } \\
\text { Descuido das pessoas }\end{array}$} \\
\hline Entrevistado & Expressões Chave \\
\hline $\begin{array}{l}\text { HPSH002b } \\
\text { DMG }\end{array}$ & $\begin{array}{l}\text { [...] Um descuido das pessoas. [...] Eu tava conversando com uma } \\
\text { [...] agente da epidêmica passa aqui, aí ela falou assim que a } \\
\text { maioria das coisa do serviço dela é catar lixo do quintal das } \\
\text { pessoas. [...] Então, tipo assim, é uma doença que tá sendo } \\
\text { contaminada né, por descuido da população... [...] Falta mais da } \\
\text { população ter uma conscientização... [...] Eu acho que é descuido } \\
\text { das pessoas, resumindo numa palavra, numa frase. [...] Pela forma } \\
\text { que ela é transmitida né, porque a maioria... água parada, ali tem } \\
\text { né, vai ter a larva, aí vai ter né produção do mosquito... [...] Que } \\
\text { passe, vamos supor, que passe uma vez por mês, dá as } \\
\text { orientações, cê ela passar daqui } 15 \text { dias tá lá o lixo de novo... [...] } \\
\text { Eu acho que é isso... }\end{array}$ \\
\hline $\begin{array}{l}\text { HPSH005b } \\
\text { RCS }\end{array}$ & $\begin{array}{l}\text { [...] A Dengue significa pra mim uma doença causada pela falta de } \\
\text { cuidado né com resíduos, [...] com restos de alimentos, uma falta } \\
\text { mesmo de cuidado da população com a saúde, né? Uma falta de } \\
\text { cuidado, porque a partir do momento, se a gente trabalhasse } \\
\text { melhor, conforme já te falei, trabalhasse melhor a nossa higiene, os } \\
\text { nossos rejeitos de lixo, tudo, acho que a gente poderia evitar né? } \\
\text { Seria uma falta disso, porque hoje em dia a gente produz muito lixo } \\
\text { né, a gente produz uma quantidade razoável de lixo, e não cuida } \\
\text { né, não dá tanto o destino adequado, vamos falar isso. }\end{array}$ \\
\hline
\end{tabular}

\begin{tabular}{|l|l|}
\hline \multicolumn{1}{|c|}{$\begin{array}{c}\text { D } \\
\text { Consequência da falta de educação }\end{array}$} \\
\hline Entrevistado & \multicolumn{1}{|c|}{ Expressões Chave } \\
\hline $\begin{array}{l}\text { HPSH005b } \\
\text { RCS }\end{array}$ & $\begin{array}{l}\text { [...] Eu falo que a Dengue também é um produto da falta de } \\
\text { educação do indivíduo né? Da falta de educação [...] A gente é } \\
\text { muito mal educado nesse sentido, a gente não tem cuidado, não } \\
\text { tem. Vai jogar, não tem o cuidado de abrir o lixo, pra por o lixo } \\
\text { dentro do lixo, joga fora e não coisa... né? [...] É a falta de educação } \\
\text { do ser humano e a falta do destino adequado do lixo. }\end{array}$ \\
\hline $\begin{array}{l}\text { HPSH017b } \\
\text { APS }\end{array}$ & $\begin{array}{l}\text { Eu diria que a Dengue é uma consequência do mal, da mal } \\
\text { educação da população. [...] É... tudo consequência do do } \\
\text { desenvolvimento nosso mesmo, precário. [...] É a consequência da } \\
\text { má educação, dos maus hábitos, do não treinamento né, ou do } \\
\text { treinamento precário, ou da falta de consciência, é isso. [...] Esses } \\
\text { terrenos abandonados. Do lado da minha casa eu já fiz inúmeras } \\
\text { denúncias pra prefeitura, a prefeitura notifica o dono do terreno, ele } \\
\text { vai lá, da uma limpadinha... }\end{array}$ \\
\hline
\end{tabular}




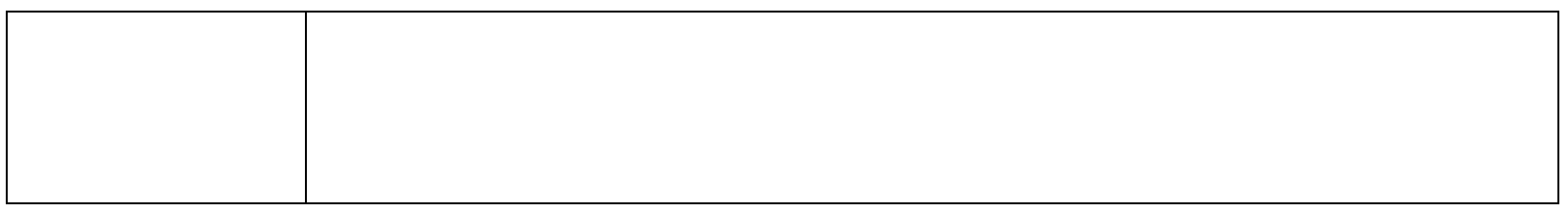

\begin{tabular}{|l|l|}
\hline \multicolumn{2}{|c|}{$\begin{array}{c}\text { E } \\
\text { Doença viral }\end{array}$} \\
\hline Entrevistado & \multicolumn{1}{|c|}{ Expressões Chave } \\
\hline $\begin{array}{l}\text { HPSH007b } \\
\text { WMS }\end{array}$ & $\begin{array}{l}\text { Dengue é uma doença viral, febril. [...] Porque a gente como } \\
\text { Enfermeiro, como trabalhador da área de saúde, a gente tem a a } \\
\text { nossa visão técnica né? Então eu ia falar que é uma doença viral, } \\
\text { uma doença febril, é uma doença que apresenta tais sintomas. [... } \\
\text { Então meu ponto de vista técnica é uma doença viral, febril, que } \\
\text { não tem medicação específica, a gente trata somente os sintomas, } \\
\text { observa sinais de alerta. }\end{array}$ \\
\hline HPSH011b & $\begin{array}{l}\text { [... É uma doença viral. Uma doença viral e que pode causar febre, } \\
\text { mal estar, dor nas articulações, mas que, que dependendo do tipo } \\
\text { de Dengue, [...] tem medicamento, tem solução, ela vai curar. Não é } \\
\text { uma doença também de bicho de sete cabeças não, eu não acho } \\
\text { não! A partir do momento que você diagnóstica bem rápido e toma } \\
\text { os devidos cuidados. [...] Doença viral, viral, que tem sintomas né, } \\
\text { dor de cabeça, febre, como sintoma de gripe, e mal estar, só que } \\
\text { tem que tomar medicamento, dipirona... }\end{array}$ \\
\hline
\end{tabular}

\begin{tabular}{|c|c|}
\hline \multicolumn{2}{|r|}{$\begin{array}{c}\text { F } \\
\text { Preocupação e medo }\end{array}$} \\
\hline Entrevistado & Expressões Chave \\
\hline $\begin{array}{l}\text { HPSH004b } \\
\text { ECLF }\end{array}$ & $\begin{array}{l}\text { Preocupação. Porque assim, é um caso que tá todo mundo assim } \\
\text { preocupado, entre aspas né, preocupado com a casa do outro e } \\
\text { esquece que dentro da sua casa também tem esse problema. [...] } \\
\text { Dengue é uma doença que pode matar se não for bem tratada, } \\
\text { então a gente tem que ficar em cima do paciente, tem que } \\
\text { monitorar. [...] Porque querendo ou não é uma preocupação, porque } \\
\text { pode matar né? E por mais a gente informa o paciente, informa a } \\
\text { população, ainda tá um descaso vindo da população. Eles querem } \\
\text { cobrar do governo, eles querem cobrar da prefeitura, mas a gente } \\
\text { tem que fazer nossa parte. }\end{array}$ \\
\hline $\begin{array}{l}\text { HPSH016b } \\
\text { PLG }\end{array}$ & $\begin{array}{l}\text { [...] Preocupação, medo, é... acho que a gente tem que dar mais } \\
\text { informação, acho que talvez mediante a este susto que a população } \\
\text { passou agora, talvez tenha mais conscientização. [...] A população } \\
\text { não adere, não aceita, não conc.. mesmo ficando doente, tá? } \\
\text { Acredito que naquela época deve ter tomado algum cuidado maior, }\end{array}$ \\
\hline
\end{tabular}




\begin{tabular}{|l|l|}
\hline $\begin{array}{l}\text { resolveu tirar as coisas da horta, os pneus, a gente já juntava e } \\
\text { agora já apagou da memória. Que é o perfil da população né? [...] } \\
\text { eu assisti de perto e.. e é muito triste né, as pessoas dessa vez } \\
\text { ficaram muito ruim. } \\
\text { [...] Motivo de preocupação, [...] não sei se vai ser melhor se a } \\
\text { vacina ou pior, [...] se não se conscientizar não vai... só ela não... É } \\
\text { um motivo de preocupação porque nós da saúde temos a } \\
\text { consciência, e às vezes não fazemos tudo certo, mas nós pelo } \\
\text { menos tamo vendo, e quem não tá vendo, sofreu a doença e não, e } \\
\text { não vai fazer nada, não vamo conseguir mudar, entendeu? Mas } \\
\text { muita preocupação. Porque se esse ano foi desse jeito, imagina o } \\
\text { que pode ser o ano que vem. E não acabou, um caso ainda } \\
\text { aparece, não tem fim. }\end{array}$ \\
\hline
\end{tabular}

\begin{tabular}{|l|l|}
\hline \multicolumn{1}{|c|}{\begin{tabular}{c}
\multicolumn{1}{c|}{ G } \\
Doença grave
\end{tabular}} \\
\hline Entrevistado & \multicolumn{1}{c|}{ Expressões Chave } \\
\hline $\begin{array}{l}\text { HPSH003b } \\
\text { FAP }\end{array}$ & $\begin{array}{l}\text { [...] Eu acho que é um caso muito grave, apesar de ser um tempo } \\
\text { curto do processo dela, de } 7 \text { a 20 dias, mas esse ano a gente teve } \\
\text { casos muito graves aqui no bairro, que no ano passado parecia } \\
\text { uma gripinha muito fraquinha, no máximo em } 7 \text { dias tinha acabado, } \\
\text { agora dessa vez está durando 15, 20 dias... então eu acho que tá } \\
\text { piorando a cada vez mais, tem que se preocupar mesmo. Porque } \\
\text { não depende só da gente orientar né, se a pessoa não aplicar o que } \\
\text { a gente orienta, que não pode deixar água parada, evitar todo tipo } \\
\text { né, não adianta nada nosso trabalho. }\end{array}$ \\
\hline $\begin{array}{l}\text { HPSH010b } \\
\text { ECPG }\end{array}$ & $\begin{array}{l}\text { [...] por menos que pareça uma coisa simples, não é tão simples. É } \\
\text { uma coisa que eu não gostaria de ter, que ninguém na minha } \\
\text { família tivesse, mas que a gente tem que tomar os cuidados para } \\
\text { que ela não aconteça. Então não ficar tão distante né, então se } \\
\text { policiar, né, com coisas simples, mesmo dentro da nossa casa, as } \\
\text { nossas plantas, com a nossa geladeira, com o nosso quintal, com } \\
\text { os nossos descartáveis que fica às vezes entulhado [...]. Ela } \\
\text { significa pra mim, uma doença grave, que eu não gostaria de ter. }\end{array}$ \\
\hline
\end{tabular}




\begin{tabular}{|c|c|}
\hline \multicolumn{2}{|r|}{ Doença causada pela picada do mosquito } \\
\hline Entrevistado & Expressões Chave \\
\hline $\begin{array}{l}\text { HPSH006b } \\
\text { APOG }\end{array}$ & $\begin{array}{l}\text { Pra mim seria a picada do mosquito né, Aedis aegipty, geralmente é } \\
\text { causada por [...] acúmulo de lixos, né, acúmulo de água nos pneus, } \\
\text { em garrafas, entendeu? [...] Os sintomas, né, mais comuns... dor no } \\
\text { fundo dos olhos, febre alta, em torno de } 39,5^{\circ} \text {, [...] às vezes começa } \\
\text { aparecer aqueles formigamento no corpo, tudo vermelhinho, a partir } \\
\text { do sexto, sétimo dia, o nível de plaquetas começa a baixar, abaixo } \\
\text { de } 150 \text { mil. Pra mim é a picada do mosquito entendeu, que pode } \\
\text { causar a Dengue. }\end{array}$ \\
\hline $\begin{array}{l}\text { HPSH008b } \\
\text { AAS }\end{array}$ & $\begin{array}{l}\text { [...] Que a Dengue é uma doença... causada pelo mosquito que } \\
\text { pode levar à morte. Que precisa ser tratada, que precisa ser } \\
\text { notificada, e cuidada. Pra mim a Dengue é isso. }\end{array}$ \\
\hline
\end{tabular}

\begin{tabular}{|l|l|}
\hline \multicolumn{2}{|c|}{$\begin{array}{c}\text { I } \\
\text { Epidemia }\end{array}$} \\
\hline Entrevistado & \multicolumn{1}{c|}{ Expressões Chave } \\
\hline $\begin{array}{l}\text { HPSH014b } \\
\text { VLS }\end{array}$ & $\begin{array}{l}\text { [... A A Dengue se tornou um caso de epidemia mesmo, tá? Onde } \\
\text { nós que nos enfrentar cada ano um tipo de vírus diferente. } \\
{[\ldots] \text { Então eu acho que isso é a Dengue para mim hoje, é uma }} \\
\text { epidemia, já se tornou caso sério dentro da saúde pública. [...] Nós } \\
\text { enfrentamos uma guerra com a Dengue aqui nesses últimos meses. }\end{array}$ \\
\hline
\end{tabular}

\begin{tabular}{|c|c|}
\hline \multicolumn{2}{|r|}{$\underset{\mathrm{J}}{\text { Outros significados }}$} \\
\hline Entrevistado & Expressões Chave \\
\hline $\begin{array}{l}\text { HPSH010b } \\
\text { ECPG }\end{array}$ & $\begin{array}{l}\text { Eu diria que a Dengue é uma doença de, de país pobre, mas que } \\
\text { infelizmente a gente tá vivenciando nos dias atuais [...]. }\end{array}$ \\
\hline $\begin{array}{l}\text { HPSH014b } \\
\text { VLS }\end{array}$ & $\begin{array}{l}\text { A Dengue pra mim significa é, na realidade, uma guerra patológica. } \\
\text { Porque cada época é algo diferente, sintomatologia diferente, de } \\
\text { paciente pra paciente, de ano pra ano. O ano passado foi uma } \\
\text { sintomatologia que o paciente apresentou e hoje, apresentou esse } \\
\text { ano, outro tipo de sintomatologia. Então, eu acho que é, na } \\
\text { realidade, uma guerra que nós estamos vivendo, tá? }\end{array}$ \\
\hline
\end{tabular}


O significado: tipo uma guerra, que onde nós Enfermeiros, nós, todos da área de saúde temos que enfrentar essa epidemia, temos que, não só no dia-a-dia, mas eu acho que temos que estudar, [...] porque que o ano que vem vai ser outro tipo; [...] a gente fica realmente preocupado com isso. 
IAD2-2

\section{Instrumento de Análise do Discurso 2:}

Pergunta 2: Se essa mesma pessoa lhe perguntasse ainda: "Para você, o que dificulta o controle da Dengue?" O que você Ihe diria?

\begin{tabular}{|c|c|}
\hline \multicolumn{2}{|r|}{$\begin{array}{l}\text { A } \\
\text { Falta de conscientização da população }\end{array}$} \\
\hline Entrevistado & Expressões Chave \\
\hline $\begin{array}{l}\text { HPSH002b } \\
\text { DMG }\end{array}$ & $\begin{array}{l}\text { [...] Acho que a população dificulta! E não é falta de conhecimento } \\
\text { não, porque a mídia tá aí, nós estamos aqui, têm os profissionais. } \\
\text { Eu acho que é descuido mesmo. [...] Não é que eles não têm } \\
\text { noção, que eles têm, eu acho que é mais descuido mesmo; eles } \\
\text { não têm a conscientização, o mal que pode tá trazendo. [...] Seria a } \\
\text { população mesmo... eles dificultam. }\end{array}$ \\
\hline $\begin{array}{l}\text { HPSH003b } \\
\text { FAP }\end{array}$ & $\begin{array}{l}\text { O que dificulta é a população, o entendimento da população. } \\
\text { Quando você vai orientar "ah, eu já sei disso, não sei o que", mas } \\
\text { como que tá tendo Dengue lá se ela já sabe de tudo que a gente } \\
\text { orienta, entendeu? Então o maior problema é a conscientização da } \\
\text { população. Acho que enquanto não começar montar mesmo, ter as } \\
\text { coisas mais forte, não vai acabar. Uma pena mesmo. [...] Agora } \\
\text { enquanto ficar só esses agentes endêmicos indo de casa em casa } \\
\text { só falando, muitos nem abrem a porta, entendeu? É um trabalho } \\
\text { difícil, acho que falta é educação da população, a população não é } \\
\text { educada. Conscientização mesmo. A falta de aderência da } \\
\text { população né, comprometimento mesmo com a doença, né? }\end{array}$ \\
\hline $\begin{array}{l}\text { HPSH004b } \\
\text { ECLF }\end{array}$ & $\begin{array}{l}\text { A população. A gente até orienta, mas, infelizmente cê vê que tem } \\
\text { muito entulho dentro de casa, os vasos de planta, né, as calhas } \\
\text { d'águas, a caixa d'água, essas cosias simplezinhas, que poderiam } \\
\text { ser tratadas, e ficam preocupados com a piscina do vizinho, que tá } \\
\text { lá com cloro, tá sujo, mas tá com cloro, e esquece que dentro da } \\
\text { minha casa também tem esse risco. Eu acho que a maioria da } \\
\text { preocupação assim nossa, a dificuldade mesmo é a } \\
\text { conscientização da população. Até mesmo sendo profissional de } \\
\text { saúde mesmo, ele fica descrente: "ah, vou orientar as mesmas } \\
\text { coisas". Talvez até dentro da minha casa tenha, eu tô orientando e } \\
\text { não tô fazendo. Então assim, eu entro na população, todos nós } \\
\text { entramos, acho que é um descaso nosso mesmo. }\end{array}$ \\
\hline $\begin{array}{l}\text { HPSH005b } \\
\text { RCS }\end{array}$ & $\begin{array}{l}\text { É a dificuldade de conscientização da pessoa. Conscientizar as } \\
\text { pessoas dos danos, porque a gente tem que trabalhar muito com } \\
\text { prevenção de danos. [...] E partir do momento que um indivíduo } \\
\text { adoece, ele causa uma série de danos não só pra ele, mas pra todo } \\
\text { o meio que ele vive. Então a gente tem que trabalhar a } \\
\text { conscientização, a educação e a prevenção. [...] A partir do }\end{array}$ \\
\hline
\end{tabular}




\begin{tabular}{|c|c|}
\hline & $\begin{array}{l}\text { momento que você educa, você previne danos. A conscientização e } \\
\text { a educação das pessoas, a falta de conscientização. }\end{array}$ \\
\hline $\begin{array}{l}\text { HPSH006b } \\
\text { APOG }\end{array}$ & $\begin{array}{l}\text { [...] A falta de conscientização das pessoas. E... muitas pessoas } \\
\text { preocupam né, mas tem outras pessoas que não ligam, que } \\
\text { mantém as casas assim todas mal arrumadas, não cuidam das } \\
\text { casas, o que prejudica muito a população. [...] Acho que o que } \\
\text { dificulta é isso, porque informação a gente [...] tá aumentando, [...] } \\
\text { tá correndo bem, a gente tá informando, fazendo panfletos, fazendo } \\
\text { trabalho com eles, mas é eu acho mais falta de conscientização } \\
\text { das pessoas. }\end{array}$ \\
\hline $\begin{array}{l}\text { HPSH007b } \\
\text { WMS }\end{array}$ & $\begin{array}{l}\text { [...] Eu acho que o que atrapalha bastante é a população, a } \\
\text { conscientização da população, porque a gente ainda vê muito é } \\
\text { falta de cuidado com o domicílio, com terrenos baldios, entendeu? } \\
\text { E tem alguns terrenos que são abandonados que ficam por conta } \\
\text { da prefeitura, mas tem muitos que são aqueles terrenos fechados, } \\
\text { murados, que não tem como a gente fazer muita coisa. Que cada } \\
\text { proprietário tem que assumir sua responsabilidade. E a gente vê } \\
\text { muito, quando a gente sai pra fazer uma campanha, o que a gente } \\
\text { vê de terreno sujo, com coisas jogadas, entendeu? E muitos casos } \\
\text { que acontece às vezes, eu na minha casa tive Dengue, mas eu } \\
\text { cuido da minha casa, mas meu vizinho não cuida, então eu pego } \\
\text { por causa do vizinho. Enquanto não tiver essa conscientização } \\
\text { mesmo da população no geral, é um predominante que dificulta } \\
\text { muito o controle da Dengue. Porque se cada um fizesse, eu fico } \\
\text { imaginando gente, se cada um tivesse seu terreno bonitinho, } \\
\text { limpinho, da onde que a gente vai criar Dengue? [...] Não vai ter } \\
\text { criadouro, então pra mim isso é primordial! Aí eu acredito que esse } \\
\text { ano se trabalhou bastante a divulgação, entendeu? Essa } \\
\text { conscientização, porque isso também é um trabalho de } \\
\text { formiguinha, você tem que persistir, persistir, persistir, e vai } \\
\text { continuar o resto da vida esse trabalho. Até as pessoas } \\
\text { conseguirem entender que é dessa forma que a gente vai erradicar. }\end{array}$ \\
\hline $\begin{array}{l}\text { HPSH009b } \\
\text { AS }\end{array}$ & $\begin{array}{l}\hat{E} \text {, por mais que tenha conscientização da população, ainda falta... } \\
\text { porque eu posso morar num bairro bom que eu tô bem protegida, } \\
\text { que não tá tendo caso, e tem um terreno que tá em situação, a } \\
\text { pessoa não se conscientiza que ela tem responsabilidade sobre } \\
\text { aquele local, sabe? [...] Então, eu acho que tem que pensar } \\
\text { também naquele pessoal que tá vivendo lá do lado. }\end{array}$ \\
\hline $\begin{array}{l}\text { HPSH011b } \\
\text { VDR }\end{array}$ & $\begin{array}{l}\text { [...] Eu acho que a população, falta de educação da população. [...] } \\
\text { Acho que a população não colabora. A gente orienta, orienta, } \\
\text { orienta, a população não colabora, ainda continua, é... acumulando } \\
\text { água, eu acho que isso ai é responsabilidade da população. Se tá } \\
\text { esse surto, é da população! Eu acho isso. Porque eu acho que o } \\
\text { pessoal da saúde orienta muito, pelo menos aqui no PSF eu vejo, } \\
\text { os agente comunitários, eu, [...] mas a população acha que isso } \\
\text { nunca vai acontecer com ele. Então, é isso. }\end{array}$ \\
\hline
\end{tabular}




\begin{tabular}{|c|c|}
\hline $\begin{array}{l}\text { HPSH014b } \\
\text { VLS }\end{array}$ & $\begin{array}{l}\text { Ah, é o vizinho. Eu faço, mas o meu vizinho não faz. [...] "por que } \\
\text { que eu faço a limpeza da minha casa, eu cuido da minha casa, e a } \\
\text { minha vizinha não cuida da casa dela?" [...] "ele não deixa ninguém } \\
\text { entrar na casa dele, nem o pessoal da Dengue pra fazer o controle } \\
\text { da Dengue." Essa foi a maior pergunta que foram feitas pra mim } \\
\text { dos pacientes: "que eu faço com o meu vizinho?" Porque a } \\
\text { população tem que se conscientizar, mas não no período da da } \\
\text { Dengue. Então, essa preocupação também é do pessoal da } \\
\text { vigilância, que faz as visitas [...] nas nossas micro áreas, é o } \\
\text { vizinho, que é a preocupação. } \\
\text { Na minha opinião o que dificulta o controle da Dengue é a } \\
\text { conscientização da população com relação à gravidade da Dengue. } \\
\text { Eu acho que tem que os meios de comunicações [...] informar a } \\
\text { população realmente da seriedade da Dengue. [...] Mas o que mais } \\
\text { compromete a Dengue é o cuidado do vizinho que não tem cuidado } \\
\text { com a casa, que a população toda não sabe a gravidade da da } \\
\text { Dengue; e nós fizemos panfletagem, nós fizemos conscientização } \\
\text { porta a porta, os agentes foram em cada área, cada micro área } \\
\text { conscientizar a população, mas o retorno foi pequeno. }\end{array}$ \\
\hline $\begin{array}{l}\text { HPSH015b } \\
\text { DCC }\end{array}$ & $\begin{array}{l}\text { [...] As pessoas se conscientizar que elas têm que cuidar do seu } \\
\text { quintal, não só do seu quintal, também se ver alguma coisa errada } \\
\text { em um lugar assim que é foco tem que falar pra vigilância, é.. } \\
\text { deixar os agentes de endemia entrar, é... O que dificulta é isso. }\end{array}$ \\
\hline $\begin{array}{l}\text { HPSH016b } \\
\text { PLG }\end{array}$ & $\begin{array}{l}\text { As pessoas, não tem outra, é totalmente responsabilidade nossa } \\
\text { [...] o controle é nosso mesmo, não tem outro culpado, somos nós } \\
\text { que somos os culpados. [...] Em alguns bairros tem muita oficinas } \\
\text { que ficam abertas aí, a céu aberto, eles costumam lavar os carros, } \\
\text { jogar água nas mangueiras e ali onde cai aquela água, não tiram a } \\
\text { água. [...] A culpa é nossa mesmo, não tem outra, o controle } \\
\text { sempre vai ser nosso, e talvez isso vai dificultar mesmo com essa } \\
\text { vacina, porque eles vão achar que tão imunizado, vai só piorar. }\end{array}$ \\
\hline
\end{tabular}

B

Resistência e falta de responsabilidade das pessoas

\section{Entrevistado}

HPSH008b AAS

\section{Expressões Chave}

O que dificulta o controle da Dengue é, eu acredito que é a resistência das pessoas em cuidar do seu pedaço, da sua casa. É de ouvir as orientações que são dadas através da televisão, através dos agentes, né, que fazem a visita em casa, dos agente de endemias, e só que eu acho que cada um acha que eles não vão 


\begin{tabular}{|l|l|}
\hline $\begin{array}{l}\text { Her, né? Que o meu vizinho vai ter e eu não vou ter, então acho que } \\
\text { isso dificulta, essa conscientização mesmo, de cada um. Isso que } \\
\text { eu acho. }\end{array}$ \\
\hline SMR & $\begin{array}{l}\text { [...] Se cada ser humano [...] soubesse a importância de fazer a } \\
\text { prevenção da Dengue, eu acho que isso ajudaria muito né nesse } \\
\text { contexto todo. O que dificulta, eu acho que não é a falta de } \\
\text { informação, é a falta de responsabilidade, e a responsabilidade } \\
\text { como ser humano, como cidadão, de pensar no próximo, ser } \\
\text { humano, entendeu? A prevenção mesmo, se cada um cuidasse do } \\
\text { seu local, né, eu acho que isso mudaria muito. [...] Então, é por aí } \\
\text { mesmo. }\end{array}$ \\
\hline
\end{tabular}

\begin{tabular}{|c|c|}
\hline \multicolumn{2}{|r|}{$\begin{array}{c}\text { C } \\
\text { Muitas questões }\end{array}$} \\
\hline Entrevistado & Expressões Chave \\
\hline $\begin{array}{l}\text { HPSH001b } \\
\text { CPA }\end{array}$ & $\begin{array}{l}\text { [...] Eu vou falar pra ela que o que dificulta o controle da Dengue é a } \\
\text { alta proliferação do mosquitinho... [...] Eu não sei nem se não quer } \\
\text { cuidar, mas a dificuldade que é isso. Porque não é fácil! [...] Essa } \\
\text { questão do mosquito mesmo. Da dificuldade de você localizar, [...] } \\
\text { tem muito foco. E todo mundo tem vasilha em casa, por mais que } \\
\text { cuide. [...] esses reservatórios de água que todo mundo tá } \\
\text { acumulando, guardando a água, eu diria que mais por isso mesmo. } \\
\text { [...] Porque o bichinho é safado! Acho que tem que acabar com o } \\
\text { mosquito mesmo pra acabar com a doença [...] não tem outro jeito. } \\
\text { É a questão do mosquito se proliferar facilmente em água e ter } \\
\text { muito foco, uma quantidade grande de foco. }\end{array}$ \\
\hline $\begin{array}{l}\text { HPSH009b } \\
\text { AS }\end{array}$ & $\begin{array}{l}\text { [...] Eu não sei porque que [...] teve esse número elevado de casos. } \\
\text { A epidemiologia, o pessoal que passa não me apresentou nada; se } \\
\text { fizeram estudo, se já chegaram a alguma conclusão. [...] O que } \\
\text { dificulta o controle eu acho que é o levantamento do que que tá } \\
\text { causando, tendeu? [...] que que dificultou o controle daqui? [...] } \\
\text { Qual que é a justificativa da epidemiologia, do pessoal que tá } \\
\text { fazendo as visitas... [...] Eles encontraram o que, mais o que nas } \\
\text { casas? É onde que tá o maior foco? Por quê? Eu não tive... então, } \\
\text { o que dificulta o controle é o que você tem que saber a causa pra } \\
\text { poder combater. [...] Porque assim, cê fica sabendo o quê? Pra } \\
\text { controlar cê não pode deixar água parada, que não sei o que... toda } \\
\text { essa teoria, mas e quando encontra um maior número de casos } \\
\text { igual aqui, por quê? [...] Porque que o mosquito disseminou tanto } \\
\text { aqui? Aí, então o que dificulta o controle é você (não) saber porque } \\
\text { que tá causando naquele lugar, que que tá causando o maior } \\
\text { número de casos naquele lugar, e eu não sei o porquê, eu não sei } \\
\text { te falar. [...] Aí, então o que dificulta o controle é cê não saber a } \\
\text { causa, do que tá, né, o que que tá causando aquilo. }\end{array}$ \\
\hline
\end{tabular}




\begin{tabular}{|c|c|}
\hline $\begin{array}{l}\text { HPSH010b } \\
\text { ECPG }\end{array}$ & $\begin{array}{l}\text { A falta de informação, principalmente relacionado à doença em sí. } \\
\text { [...] A pessoa pensa que é o mosquitinho que pica e que você vai } \\
\text { ter ali uma dorzinha, mas que é uma coisa passageira, a pessoa } \\
\text { não tem ideia da complexidade do que a Dengue é em si. [...] A } \\
\text { pessoa ainda não sabe o que realmente é a Dengue [...] das } \\
\text { consequências, da complexidade que a doença pode trazer em sí. } \\
\text { [...] Eu acho que a informação em relação a prevenção, ela tá mais } \\
\text { que clara, né? Ela ficou muito clara! Agora nós vamo ter que } \\
\text { esmiuçar um pouquinho mais, divulgar mais a doença, o que é a } \\
\text { doença. Eu acredito que, assim, ficou em cima dos sintomas [...]. }\end{array}$ \\
\hline $\begin{array}{l}\text { HPSH012b } \\
\text { NR }\end{array}$ & $\begin{array}{l}\text { [...] Aí vai entrar, acho que em muitas questões. Vai entrar questão } \\
\text { climática mesmo, sabe, desde o clima, da região geográfica, até o } \\
\text { comprometimento das pessoas, o recurso de infraestrutura, o } \\
\text { recurso de recursos humanos pra trabalhar, envolve tudo isso. } \\
\text { Principal acho que é, conseguir o comprometimento de todo } \\
\text { mundo, porque ele envolve tanto o profissional que tem que ter } \\
\text { recurso humano, ele tem que ter infraestrutura pra trabalhar, mas } \\
\text { ele envolve outro lado que é a comunidade, então eu tenho que } \\
\text { trabalhar a cabecinha da comunidade, e às vezes uma casa faz } \\
\text { certinho e três casas já não adere aquela orientação que recebeu, } \\
\text { então pra mim o mais difícil é isso. }\end{array}$ \\
\hline $\begin{array}{l}\text { HPSH015b } \\
\text { DCC }\end{array}$ & $\begin{array}{l}\text { E também [...] saiu um boato que tinha um ladrão vestido de agente } \\
\text { de endemia entrando nas casas, aí eu acho que isso também, [...] a } \\
\text { pessoa cria resistência e não deixa os agentes de saúde entrar, } \\
\text { causa meio que medo na população. }\end{array}$ \\
\hline $\begin{array}{l}\text { HPSH017b } \\
\text { APS }\end{array}$ & $\begin{array}{l}\text { Eu diria que o que dificulta é a capacitação dos agentes, [...] não é } \\
\text { o número, porque a gente tem um grande número que daria conta } \\
\text { de manter no mínimo controlado o caso de Dengue, mas assim, o } \\
\text { que dificulta o treinamento. [...] no caso aqui de Alfenas, eles já } \\
\text { pensam assim, vou entrar na prefeitura porque funcionário público } \\
\text { não trabalha, aí o dia que tá com sol quente eles não saem, dia que } \\
\text { chove eles não saem, já não trabalham, os agentes de endemias. } \\
\text { E assim, eu acho que falta também, dos PSFs, mais cobrança em } \\
\text { cima dos agentes de saúde, porque [...] a visita do agente de saúde } \\
\text { não é um mero: "você tá precisando de alguma coisa, um médico } \\
\text { vai atender tal dia, né?" Acho que mais uma educação permanente } \\
\text { do que uma continuada. }\end{array}$ \\
\hline
\end{tabular}




\section{IAD2-3}

Instrumento de Análise do Discurso 2:

Pergunta 3: Para você, o que facilita o controle da Dengue?

\begin{tabular}{|c|c|}
\hline \multicolumn{2}{|r|}{ A } \\
\hline Entrevistado & Expressões Chave \\
\hline $\begin{array}{l}\text { HPSH003b } \\
\text { FAP }\end{array}$ & $\begin{array}{l}\text { [...] Eu acho que um dos maiores trabalhos que a gente teve } \\
\text { bastante resultados foi nas escolas. Pegar as crianças } \\
\text { pequenininha pra levar pra casa como tarefa de orientação. A } \\
\text { própria criança chegar falar assim "ó mãe, esse vasinho tá errado", } \\
\text { entendeu? Acho que esse foi nosso maior, que a gente conseguiu } \\
\text { mais resultado. [...] Mas eu acho que tinha que começar a } \\
\text { orientação nas escolas mesmo. Questão da educação mesmo, } \\
\text { desde pequenininho. }\end{array}$ \\
\hline $\begin{array}{l}\text { HPSH006b } \\
\text { APOG }\end{array}$ & $\begin{array}{l}\text { [...] Então, essas propagandas, panfletos, [...] conscientização que } \\
\text { as pessoas, [...] principalmente dessas unidades de saúde, a gente } \\
\text { tá conscientizando as pessoas, isso facilita pra ter um controle } \\
\text { melhor. Porque [...] a partir do momento que começa a passar na } \\
\text { televisão, [...] entregar panfletos, as pessoas estão vendo quais são } \\
{[\ldots] \text { os sintomas, já estão correndo atrás né, [...] se informando }} \\
\text { melhor, já ficam preocupadas. }\end{array}$ \\
\hline $\begin{array}{l}\text { HPSH007b } \\
\text { WMS }\end{array}$ & $\begin{array}{l}\text { O que facilita, o que pode colaborar é realmente o trabalho de } \\
\text { conscientização, que a gente está fazendo. [...] Usar bastante } \\
\text { mesmo o que a gente tem hoje em dia: as redes sociais, a mídia, a } \\
\text { maioria... [...] tem acesso. Então eu acho que isso é uma coisa que } \\
\text { pode facilitar muito, entendeu? De você usar mesmo desses meios } \\
\text { pra tá divulgando, pra trabalhar essa conscientização. [...] Uma hora } \\
\text { as pessoas vão conseguir entender que se cada dia eu conseguir } \\
\text { conscientizar uma pessoa, através desses meios [...] um rádio, uma } \\
\text { televisão, celular [...] com Facebook. [...] Eu acho que é uma opção, } \\
\text { que realmente o pessoal até usou bastante, Facebook, pra divulgar } \\
\text { mensagem de campanha contra a Dengue. E não deixando de lado, } \\
\text { claro que não, a tet-a-tet né, casa-a-casa, as palestras em sí tem } \\
\text { que existir, mas estar usando também esses meios de } \\
\text { comunicação que ajuda muito, facilita muito se a gente souber usar. }\end{array}$ \\
\hline $\begin{array}{l}\text { HPSH008b } \\
\text { AAS }\end{array}$ & $\begin{array}{l}\text { [....JE o pessoal não desistir de trabalhar nas orientações, né? Isso } \\
\text { facilita assim que tem os profissionais, têm os agentes que tão } \\
\text { todos os dias fazendo as mesmas orientações, [...] ajudas, } \\
\text { parcerias em orientação. Então isso pra mim é uma facilidade, é o } \\
\text { que facilita o controle. }\end{array}$ \\
\hline
\end{tabular}




\begin{tabular}{|c|c|}
\hline \multicolumn{2}{|r|}{$\begin{array}{c}\text { B } \\
\text { Educação da população }\end{array}$} \\
\hline Entrevistado & Expressões Chave \\
\hline $\begin{array}{l}\text { HPSH005b } \\
\text { RCS }\end{array}$ & $\begin{array}{l}\text { [...] Eu acho que assim, o que facilitaria, a população ter a noção da } \\
\text { gravidade da doença, e trabalhar como agentes disseminadores do } \\
\text { conhecimento. [...] Então, o que facilitaria seria a educação da } \\
\text { população. [...] Então eu acho que assim, que infelizmente as } \\
\text { pessoas chega a essa conclusão a partir do momento que elas } \\
\text { passam por esse né, passa pela dor. [...] Enquanto você está } \\
\text { falando, ninguém quer conscientizar, mas a partir do momento que } \\
\text { afeta... [...] Então quer dizer, nós somos muito mal educados. [...] } \\
\text { Gente, a educação ambiental pelo amor de Deus! Você está } \\
\text { agredindo a natureza, você passa perto de um rio, o rio tá cheio, } \\
\text { entulhado de lixo, transbordando. Então, eu acho que a Dengue, ela } \\
\text { custou muito pra aflorar, só que a Dengue não vai servir pra barrar } \\
\text { essa falta de educação. [...] Cada vez mais, nós estamos } \\
\text { produzindo mais resíduos, estamos produzindo mais lixos, estamos } \\
\text { ficando mais desorganizados, mais mal educados. }\end{array}$ \\
\hline $\begin{array}{l}\text { HPSH011b } \\
\text { VDR }\end{array}$ & $\begin{array}{l}\text { É... não deixar água acumulada, lixo acumulado também, e } \\
\text { educação. Acho que tá tudo baseado na educação da pessoa, } \\
\text { conhecimento da pessoa, eu acho isso. Acho que o conhecimento, } \\
\text { a educação, se todo mundo tivesse como deveria ter, eu acho que } \\
\text { estaria tudo certo. Acho que o povo precisa ser mais educado. Em } \\
\text { geral, né? Principalmente a população. Acho que isso tudo tá } \\
\text { relacionado com educação, acho que toda saúde da pessoa está } \\
\text { relacionada com educação. Eu acho isso. }\end{array}$ \\
\hline
\end{tabular}

\begin{tabular}{|c|c|}
\hline \multicolumn{2}{|r|}{$\begin{array}{c}\text { C } \\
\text { Consciência das pessoas }\end{array}$} \\
\hline Entrevistado & Expressões Chave \\
\hline $\begin{array}{l}\text { HPSH013b } \\
\text { SMR }\end{array}$ & $\begin{array}{l}\text { O que facilita? [...] É a consciência de cada um. Eu acho assim } \\
\text { propaganda existe [...] está na mídia. Cartazes existem pra todo } \\
\text { lado, o agente comunitário trabalha nessa própria educação } \\
\text { sanitária, [...] tem o pessoal da vigilância, os agentes da Dengue. } \\
\text { Então, o que está faltando mesmo é consciência, entendeu? Eu } \\
\text { acho que a divulgação até está sendo muito repetitiva. [...] Muitas } \\
\text { casas eu passei orientando, passei uma semana, o problema que } \\
\text { eu orientei continuava o mesmo. [...] Só jogar a responsabilidade é } \\
\text { muito mais fácil, mas as pessoas esquecem que em primeiro lugar } \\
\text { a responsabilidade é nossa, não é do prefeito, não é do seu vizinho, } \\
\text { não é de ninguém, a responsabilidade é nossa. [...] Conhecimento } \\
\text { tem, não tem é responsabilidade, comprometimento, como pessoa, } \\
\text { como cidadão, que tem todos os direitos e deveres. }\end{array}$ \\
\hline
\end{tabular}




\begin{tabular}{|l|l|}
\hline HPSH014b & $\begin{array}{l}\text { O que facilita pra mim é a conscientização, [...] a conscientização } \\
\text { da população. Utilização de meios de informação pra população, eu } \\
\text { acho que usaram muito, a Dengue já instalada, a Dengue atuando, } \\
\text { a população sofrendo com a Dengue, eu acho que deveria ter feito } \\
\text { isso a nível preventivo. É: "nós vamos estar numa época de } \\
\text { Dengue? Vamos, mas vamos fazer uma prevenção antes!" Usar os } \\
\text { meios de comunicação e informar a população sobre a Dengue, } \\
\text { quais os sintomas... Porque ninguém sabe a gravidade da Dengue, } \\
\text { só nós da saúde que sabemos a gravidade da Dengue. E esse ano } \\
\text { posso garantir pra você que foi bem pior, bem pior. [...] E a } \\
\text { população, vou dizer a verdade pra você, a população não se } \\
\text { importou com a Dengue, não se importou. E é grave. Porque a } \\
\text { população tem que se conscientizar, tem que querer fazer a parte } \\
\text { preventiva. Se eu chegar numa casa que tem um monte de } \\
\text { entulhos e conscientizar esse indivíduo, a Dengue, os cuidados } \\
\text { com a Dengue, ele fala que não existe isso não. E amanhã o } \\
\text { vizinho do lado aparece aqui com os sintomas da Dengue: "foi } \\
\text { aquele meu vizinho hein, vocês foram lá fazer visita, mas ele não } \\
\text { quis limpar a casa não, a casa está lá suja do mesmo jeito..." [...] } \\
\text { Uma questão cultural talvez, né? }\end{array}$ \\
\hline
\end{tabular}

\begin{tabular}{|c|c|}
\hline \multicolumn{2}{|r|}{$\frac{\text { D }}{\text { Saneamento básico }}$} \\
\hline Entrevistado & Expressões Chave \\
\hline $\begin{array}{l}\text { HPSH009b } \\
\text { AS }\end{array}$ & $\begin{array}{l}\text { Já está visto que a gente tem que combater o mosquito, tem que } \\
\text { combater a proliferação dele, então [...] eu acho que o caminho é } \\
\text { esse mesmo, que vai facilitar é combater. [...] Fazendo aquelas } \\
\text { velhas condutas [...]. De não deixar água parada, de olhar as } \\
\text { plantas [...] e continuar com essas outras experiências pra gente ver } \\
\text { se dá certo [...] se esses predadores derem certo, vamos pôr os } \\
\text { predadores. Aquele fumacê [...]. Eu acho que é investir em } \\
\text { experiências, investir em vacina, o caminho vai ser esse mesmo. } \\
\\
\text { E melhorar a questão de saneamento básico, já que eu acho que o } \\
\text { problema maior é o saneamento; porque é uma doença muito } \\
\text { primária, uma coisa muito básica [...]. Tem que acabar, não pode } \\
\text { continuar. }\end{array}$ \\
\hline
\end{tabular}




\begin{tabular}{|c|c|}
\hline \multicolumn{2}{|r|}{$\begin{array}{c}\text { E } \\
\text { Parcerias }\end{array}$} \\
\hline Entrevistado & Expressões Chave \\
\hline $\begin{array}{l}\text { HPSH003b } \\
\text { FAP }\end{array}$ & $\begin{array}{l}\text { [...] Esse ano também a gente teve uma parceria muito grande dos } \\
\text { agentes endêmicos, então todo caso que nós notificávamos eles já } \\
\text { vinham na casa fazer [...] a busca, pra ver se ao redor ali, [...] pra } \\
\text { jogar o fumacê, então isso foi um ponto muito importante, a } \\
\text { população ficou alerta. [...] Aí começou uma preocupação maior da } \\
\text { população. Isso foi muito bom. A gente identificava, aí a gente } \\
\text { acionava os agentes endêmicos, os agentes endêmicos iam lá na } \\
\text { casa. Aí eles faziam um trabalho melhor, entendeu? }\end{array}$ \\
\hline $\begin{array}{l}\text { HPSH004b } \\
\text { ECLF }\end{array}$ & $\begin{array}{l}\text { [...] A gente está tendo um facilitador muito grande, que é o pessoal } \\
\text { do agente de endemia, eles estão aqui no PSF, então eles estão } \\
\text { passando na nossa área, isso pra gente tá facilitando. [...] Onde tem } \\
\text { dificuldade eu pedi pra eles terem um acesso com o agente } \\
\text { comunitário [...], porque a gente tem essa dificuldade, eles não } \\
\text { estão abrindo, infelizmente, para os agentes de endemia, tem essa } \\
\text { resistência [...]. A população aqui, por ser mais instruída, não deixa } \\
\text { os agentes tarem entrando nas suas casas, mas eles são os } \\
\text { facilitadores para gente. A nossa equipe mesmo está orientada [...]. } \\
\text { A gente encaminha para a vigilância tomar uma providência [...]. } \\
\text { Aqui também tem muita gente que não recebe nem agente } \\
\text { comunitário. Mas eu acho que o facilitador mesmo é essa parceria } \\
\text { que a gente tem com o pessoal do agente de endemia. Eles estão } \\
\text { sempre atualizando a gente [...], acho que isso que está ajudando. }\end{array}$ \\
\hline $\begin{array}{l}\text { HPSH012b } \\
\text { NR }\end{array}$ & $\begin{array}{l}\dot{E} \text {, união de forças, né? [...] Nós vamos somar aí todo mundo junto, } \\
\text { aí eu acho que isso facilita. Que nem aqui, o agente de saúde está } \\
\text { junto com o agente da endemia, porque aí o agente de saúde } \\
\text { também está na casa, e aí eu acho que isso facilita. [...] Você vê } \\
\text { que quando unem forças, o resultado é mais rápido, mais eficaz. } \\
\text { [...] Então, Alfenas tem que trabalhar mais, nós temos, porque eu } \\
\text { faço parte. }\end{array}$ \\
\hline
\end{tabular}

\begin{tabular}{|l|l|}
\hline \multicolumn{2}{|c|}{ Não há facilitadores } \\
\hline Entrevistado & \multicolumn{1}{|c|}{ Expressões Chave } \\
\hline $\begin{array}{l}\text { HPSH016b } \\
\text { PLG }\end{array}$ & $\begin{array}{l}\text { Eu nem diria assim que facilita, [...] gente teve um bom resultado } \\
\text { porque dessa vez eu consegui ver os meus pacientes de perto que } \\
\text { estavam com Dengue. Porque o hospital bloqueou lá [...] não } \\
\text { atendeu e jogou aqui e acabou que a gente assistiu mais, e das } \\
\text { outras vezes como eram poucos casos nós não tivemos essa visão. } \\
{[\ldots] \text { Agora dessa vez foi assustador [...]. Então eu não vejo nem o }}\end{array}$ \\
\hline
\end{tabular}




\begin{tabular}{|l|l|}
\hline & $\begin{array}{l}\text { que facilitou, eu achei assim que a Dengue dessa vez ajudou nós } \\
\text { enxergarmos melhor os nossos pacientes. }\end{array}$ \\
\hline
\end{tabular}

\begin{tabular}{|l|l|}
\hline \multicolumn{2}{|c|}{$\begin{array}{c}\text { G } \\
\text { Informações }\end{array}$} \\
\hline Entrevistado & \multicolumn{1}{|c|}{ Expressões Chave } \\
\hline $\begin{array}{l}\text { HPSH010b } \\
\text { ECPG }\end{array}$ & $\begin{array}{l}\text { O que facilita é essa quantidade de informação, eu acho que hoje } \\
\text { em dia qualquer lugar que você for, você tiver num mercado você } \\
\text { vai achar um cartazinho falando. Pelo menos a gente pregou cartaz } \\
\text { em tudo quanto que foi estabelecimento, então, as informações } \\
\text { estão ali muito presentes, tanto na internet, a televisão, então } \\
\text { assim, as informações elas são o que facilitam. }\end{array}$ \\
\hline $\begin{array}{l}\text { HPSH015b } \\
\text { DCC }\end{array}$ & $\begin{array}{l}\text { l... Pra mim eu acho que são essas divulgações, na televisão, } \\
\text { panfletagem, o próprio agente de endemia, o PSF, com os agentes } \\
\text { de saúde é orientando nas casas. }\end{array}$ \\
\hline
\end{tabular}

\begin{tabular}{|c|c|}
\hline \multicolumn{2}{|r|}{$\frac{H}{\text { Diversos facilitadores }}$} \\
\hline Entrevistado & Expressões Chave \\
\hline $\begin{array}{l}\text { HPSH001b } \\
\text { CPA }\end{array}$ & $\begin{array}{l}\text { [...] A conscientização ajuda. O trabalho de educação em saúde } \\
\text { facilita. O governo, quando [...] começa a fazer propaganda. [...] } \\
\text { Quando a própria vigilância descobre que tem um foco e vai lá, faz } \\
\text { o trabalho deles... [...] fumacê, eu acho que ajuda no controle } \\
\text { também. Quando a gente notifica [...] eles ficam mais atentos, isso } \\
\text { também ajuda. [...] Educação. E eu acho que o trabalho dos nossos } \\
\text { gestores de estar fazendo a parte deles, de divulgar, de estar } \\
\text { intervindo [...]. }\end{array}$ \\
\hline $\begin{array}{l}\text { HPSH002b } \\
\text { DMG }\end{array}$ & $\begin{array}{l}\text { Uai, se a população fizesse a parte dela... [...] A população tem que } \\
\text { fazer a parte dela. [...] Porque eu acho que, a maioria das coisas, é } \\
\text { dentro de casa que eles acham o foco. [...] Porque a gente faz a } \\
\text { nossa parte profissional, [...] as pessoas, elas têm que tornar mais } \\
\text { responsáveis também pelas coisas [...]. }\end{array}$ \\
\hline $\begin{array}{l}\text { HPSH003b } \\
\text { FAP }\end{array}$ & $\begin{array}{l}\text { [...]Mas acho que tem que voltar mesmo pra parte de cobrança, eu } \\
\text { não falo de dinheiro, nem se for serviço social, alguma coisa, aí a } \\
\text { população vai começar a ver mais, prestar mais atenção né. }\end{array}$ \\
\hline
\end{tabular}




\begin{tabular}{|l|l|}
\hline HPSH017b & Eu acho que o que facilita é a gente tá capacitando melhor os \\
APS & agentes, [...] e remuneradamente também, eu acho que é o que \\
& ajuda. Porque se ele é bem pago, ele vai querer trabalhar pra ver o \\
& resultado. [...] Acho que se eles tivessem um incentivo maior, [...] \\
& financeiramente, [...] ajudaria, porque eles iam trabalhar em cima de \\
produção, e isso ia diminuir os casos também de Dengue.
\end{tabular}

